\title{
EVOLUÇÃO TECTONO-SEDIMENTAR DO INTERVALO ORDOVICIANO-DEVONIANO DA BACIA DO PARANÁ COM ÊNFASE NA SUB-BACIA DE ALTO GARÇAS E NO PARAGUAI ORIENTAL
}

\author{
EGBERTO PEREIRA
}

Orientador: Prof. Dr. Vicente José Fulfaro

TESE DE DOUTORAMENTO

COMISSÃO JULGADORA

Nome

Presidente: Prof. Dr. Vicente José Fulfaro

Examinadores: Prof. Dr. Almério Barros França

Prof. Dr. Luiz Padilha de Quadros

Prof ${ }^{\text {a. }} \mathrm{Dr}^{\mathrm{a}}$. Maria Antonieta da C. Rodrigues

Prof. Dr. Setembrino Petri

$$
\begin{aligned}
& \text { SÃO PAULO } \\
& 2000
\end{aligned}
$$

\section{Assinatura}

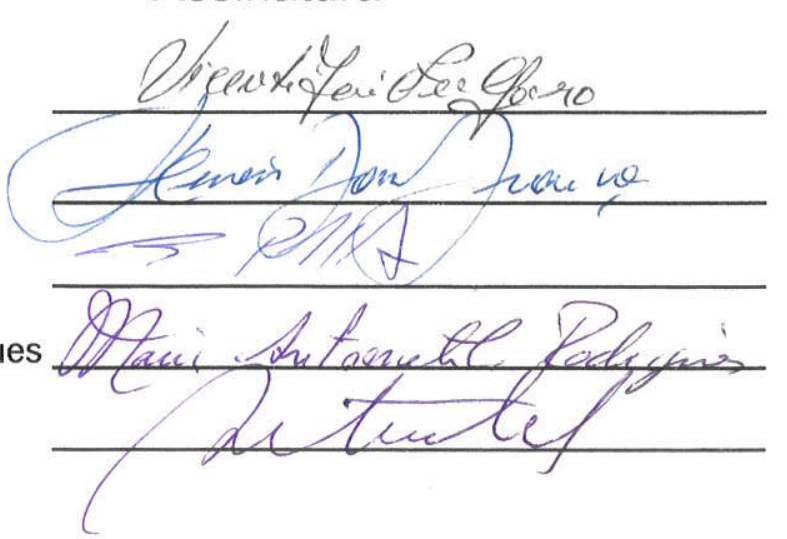




\section{UNIVERSIDADE DE SÃO PAULO \\ INSTITUTO DE GEOCIÊNCIAS}

EVOLUÇÃO TECTONO-SEDIMENTAR DO INTERVALO ORDOVICIANO - DEVONIANO DA BACIA DO PARANÁ COM ÊNFASE NA SUB-BACIA DE ALTO GARÇAS E NO PARAGUAI ORIENTAL

EGBERTO PEREIRA

ORIENTADOR: DR. VICENTE JOSÉ FÚLFARO

TESE DE DOUTORAMENTO

Programa de Pós-Graduação em Geologia Sedimentar

\section{SÃo PAULO \\ 2000}

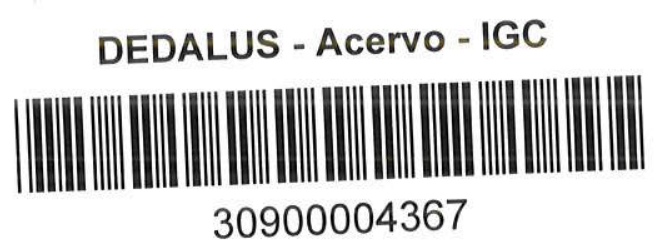


Para Telma, Francisca e aos meus pais 


\section{ÍNDICE}

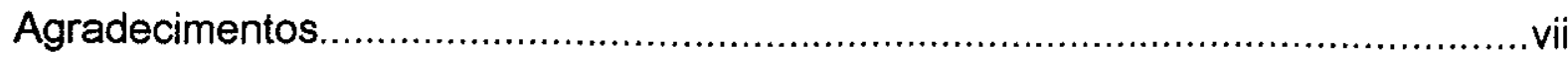

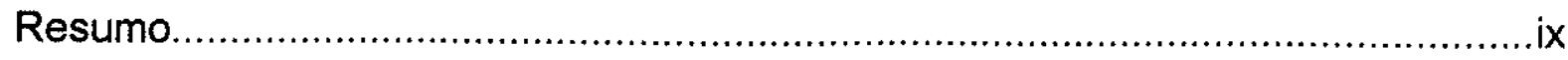

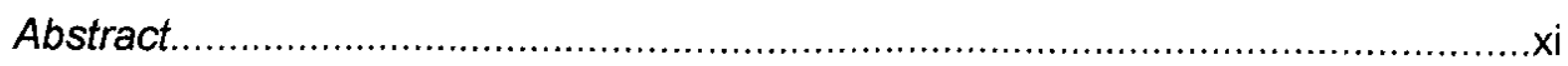

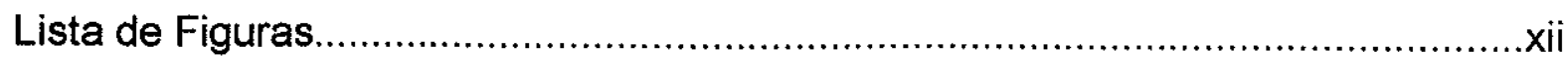

Lista de Quadros e Tabelas.................................................................xviii

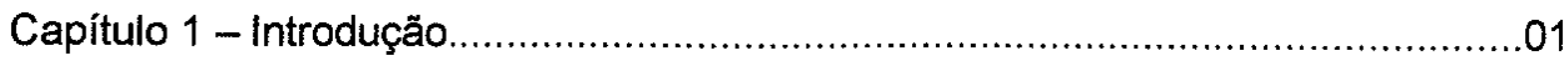

1.1 - Aspectos Gerais................................................................ 01

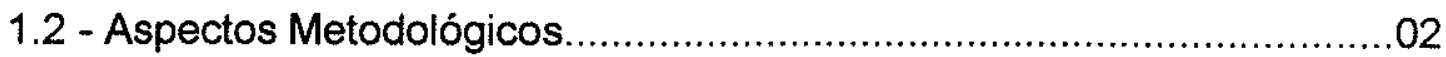

Capítulo 2 - Arcabouço de Dados........................................................ 11

2.1 - Dados Geológicos obtidos a partir de Afloramentos.........................11

2.1.1 - Dados de campo obtidos no estado de

Mato Grosso do Sul (MS) ....................................................11

2.1.1.1 - Região de Aquidauana e Cipolândia.....................11

2.1.1.2 - Região de Rio Negro........................................16

2.1.1.3 - Região de Rio Verde de Mato Grosso e Coxim.......19

2.1.1.4 - Região de Pedro Gomes e Sonora........................27

2.1.2 - Dados de campo obtidos no estado de Mato

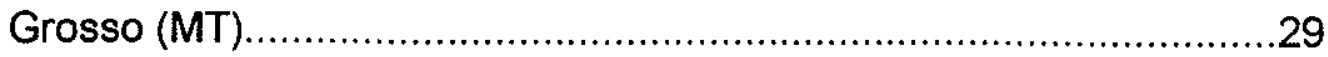

2.1.2.1 - Regiäo de Itiquira............................................29

2.1.2.2 - Região de São Lourenço de Fátima

e Rondonópolis............................................................30

2.1.2.3 - Região de Chapada dos Guimarães ......................35 
2.1.2.4 - Região de Dom Aquino.........................................40

2.1.2.5 - Região de Paranatinga e Canarana..........................42

2.1.2.6 - Região de Nova Xavantina e Vale dos Sonhos......50

2.1.2.7 - Região de Barra do Garças e General Carneiro......57

2.1.2.8 - Região de Torixoreú, Pedra Branca

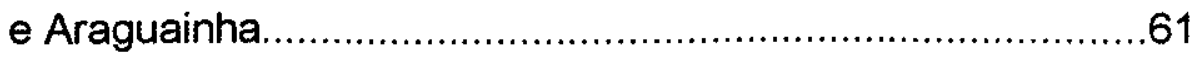

2.1.3 - Dados de campo obtidos no estado de Goiás (GO) ...............71

2.1.3.1 - Região de Amorinópolis..........................................71

2.1.3.2 - Região de Piranhas.............................................76

2.1.3.3 - Região de Baliza e Bom Jardim de Goiás...............78

2.1.4 - Dados de campo obtidos no Paraguai...................................82

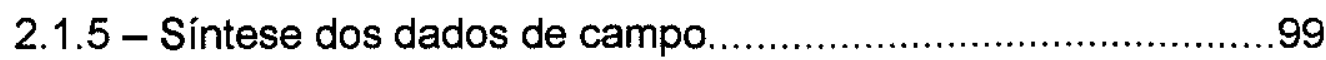

2.2 - Dados Geológicos obtidos a partir de poços e furos de

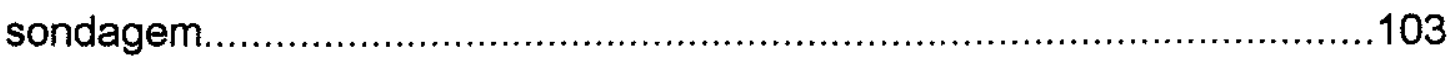

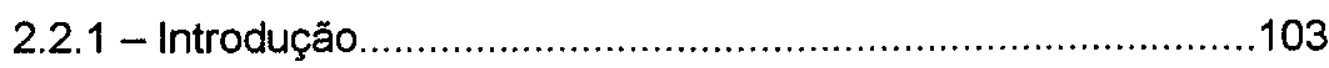

2.2.2 - Dados obtidos na parte brasileira da bacia.......................103

2.2.3 - Dados obtidos na parte paraguaia da bacia.......................107

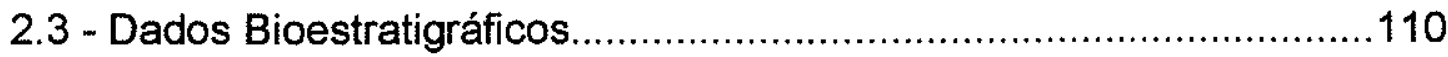

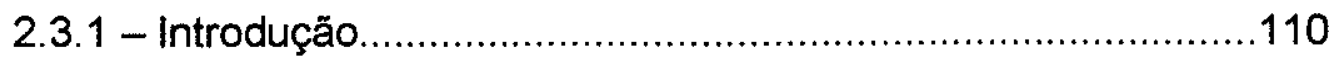

2.3.2 - Material e Método.........................................................115

2.3.2.1 - Método de Preparação das Amostras ...................119

2.3.2.2 - Método Normal de Preparação das Amostras.......120

2.3.2.3 - Método Especial de Preparação das Amostras......123

2.3.3 - Resultados Palinológicos Obtidos....................................124

2.3.3.1 - Amostras provenientes do Paraguai.....................124

2.3.3.2 - Amostras provenientes do Brasil..........................134

2.3.3.2.1 - Amostras de Poços.................................136

2.3.3.2.2 - Amostras de Afloramentos.......................140

2.3.4 - Resultados Bioestratigráficos Gerais................................142 


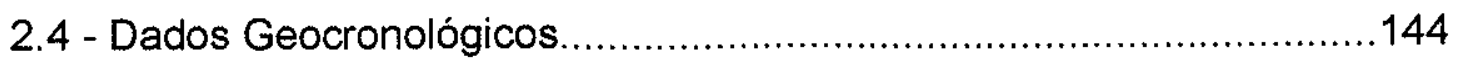

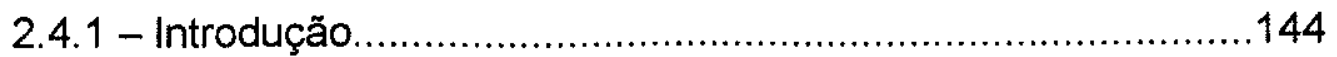

2.4.2 - Métodos de Datação radiométricas...................................145

2.4.2.1 - Premissas Básicas.............................................145

2.4.2.2 - Definição do limite Diagênese -

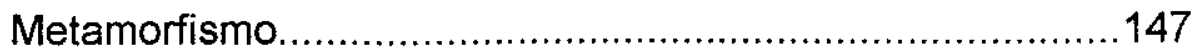

2.4.3 - Influência do Metamorfismo na Datação

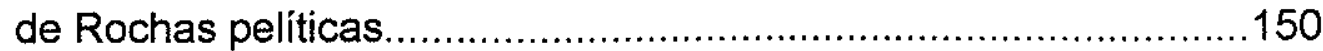

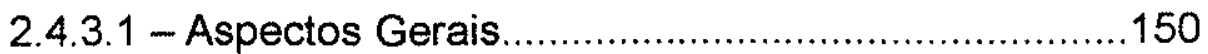

2.4.3.2 - Método Rubídio / Estrôncio....................................152

2.4.3.3 - Considerações Gerais sobre a Metodologia..........153

2.4.4 - Aplicação do método Rubídio / Estrôncio em sedimentos paleozóicos da Bacia do Paraná...........................................154

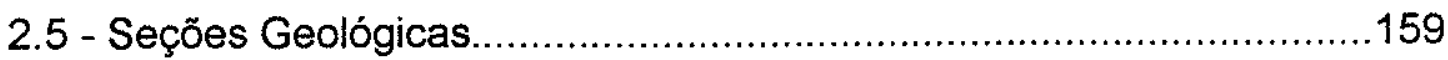

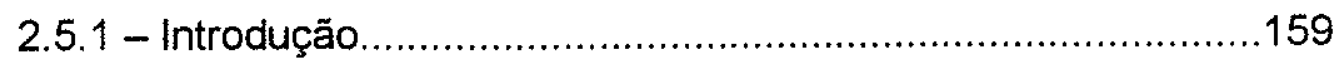

2.5.2 - Seções envolvendo rochas do Ordoviciano / Siluriano.......159

2.5.2.1 - Seção estratigráfica Chapada dos

Guimarães (MT) - Poço 2-LA-1-SP ....................................160

2.5.2.2. - Seção estratigráfica 2-DO-1-MT - Cachoeira

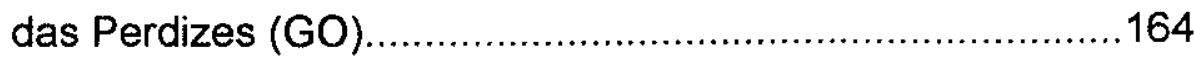

2.5.2.3. - Seção estratigráfica Assunção 1 - RD-115 ..........167

2.5.2.4. - Seção estratigráfica 269 R1 - RD-115 ...............172

2.5.3 - Seção envolvendo rochas do Eo-Devoniano.......................174

2.5.3.1 - Seção estratigráfica 2-RI-1-PR - 2-LA-1-SP ..........174

2.5.4 - Seção envolvendo rochas do Meso e Neo-Devoniano........ 180

2.5.4.1 - Seção estratigráfica 2-AG-1-MT - 2-TL-1-MT........182

2.5.4.2 - Seção estratigráfica Assunção 1 - Assunção 2....187 
Capítulo 3 - Arcabouço Estratigráfico. 191

3.1 - Introdução. 191

3.2 - Seqüências deposicionais de $2^{\circ}$ ordem. 194

3.2.1 - Seqüência Ordoviciana.................................................199

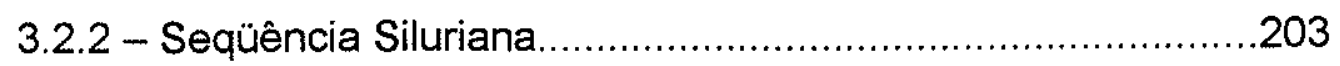

3.2.3 - Seqüência Eo-Devoniana..............................................210

3.2.4 - Seqüência Meso / Neo-Devoniana...................................216

Capítulo 4 - Arcabouço Tectônico. .223

4.1 - Origem das bacias intracratônicas. 223

4.2 - As possiveis causas para a origem da Bacia do Paraná.................226

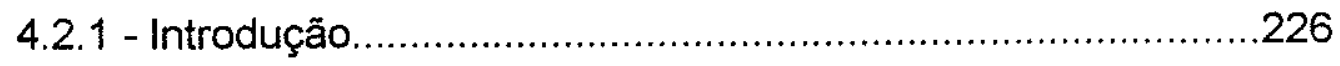

4.2.2 - O embasamento da Bacia do Paraná.................................226

4.2.3 - Arcabouço Tectônico - Estrutural........................................229

4.2.4 - A origem da Bacia do Paraná ..........................................234

4.3 - Eventos modificadores atuantes na Bacia do Paraná.......................244

Capítulo 5 - Considerações Finais e Conclusões. 248

5.1 - Considerações finais. 248

5.2 - Conclusões. 249

Capítulo 6 - Referências Bibliográficas. .256

Anexo I-Estampas I. .275 


\section{AGRADECIMENTOS}

Gostaria de expressar meus agradecimentos:

Ao Prof. Dr. Vicente José Fúlfaro, por aceitar orientar esta pesquisa. Sua larga experiência profissional, bem como seus sólidos conhecimentos sobre a evolução geológica da Bacia do Paraná, nos trouxeram o estímulo necessário para desenvolver este trabalho. À Prof ${ }^{a}$. $\mathrm{Dr}^{\mathrm{a}}$. Maria Antonieta Rodrigues, nossa maternal coordenadora, que através de seu incansável trabalho cotidiano e sua generosidade, proporcionou as condições materiais para realização dessa pesquisa. Ao Prof. Dr. Sérgio Bergamaschi, companheiro inseparável de vários anos, por sua peculiar capacidade de escutar, por longa horas, nossas opiniões e dúvidas

Ao Geól. José Henrique G. de Melo, fraterno amigo, pelo fundamental apoio na compreensão do arcabouço bioestratigráfico discutido nesta pesquisa. Ao Dr. Philippe Steemans, pela dedicação com que nos revelou o mundo dos cryptosporos, visando a montagem do arcabouço bioestratigráfico do Paraguai. Ao Dr. Philippe Gerrienne, pelas inúmeras discussões sobre a paleogeografia do Gondwana. A esses colegas sou grato, ainda, pela sincera amizade e companheirismo demonstrados ao longo de nossa estada na Bélgica.

À Prof ${ }^{\mathrm{a}}$. Dra . Ana Maria Mizusaki, pela realização das datações radiométricas das amostras coletas e pelas discussōes sobre os resultados alcançados. Ao Prof. Dr. Renê Rodrigues, pelo estímulo ao nosso trabalho e pelas facilidades junto ao Laboratório de Geoquímica Orgânica do Cenpes/Petrobrás.

Ao Prof. Hernani Chaves e ao Geól. Marco André M. Medeiros pelo auxílio na elaboração dos mapas de isópacas. Aos professores do Departamento de Estratigrafia - Paleontologia da UERJ: Dr. Yngve Grahn, Dr. Rodolfo Dino, Dr. 
Antônio Thomaz Filho, Dr. Jorge Carlos Della Fávera, Geól. Pedro de Césero, Dr. Carlos Emanoel de Souza Cruz, Dr. Edison Milani e Dr. Antônio Carlos Siqueira Fernandes, pelas proveitosas discussões sobre a estratigrafia e a evolução geológica da Bacia do Paraná.

Ao Departamento de Recursos Minerais da Republica do Paraguai, em especial à Geól. Maria Eugenia Gonçalves, pela liberação dos dados e pelo apoio a nossas etapas de campo no Paraguai. À Petrobrás, pela liberação dos dados dos poços utilizados nesta pesquisa. Ao programa PADCT/FINEP (Projeto n. ${ }^{\circ}$ 65.91.0373.00) pelo apoio financeiro à pesquisa. À FAPERJ, pelo auxílio financeiro concedido ao nosso programa de treinamento na Universidade de Liège (Bélgica) e à UERJ, pela concessão de bolsa de estudo, através do PROCAD. 


\section{RESUMO}

O estudo da evolução tectono-sedimentar da Bacia do Paraná no intervalo Ordoviciano - Devoniano, com ênfase na Sub-Bacia de Alto Garças e no Paraguai oriental, foi realizado com base na integração de dados sedimentológicos, estratigráficos, bioestratigráficos e geoquímicos, obtidos ao longo de uma ampla faixa de exposição dos sedimentos e, também, a partir da análise de 16 poços perfurados pelas companhias Petrobrás, Paulipetro e Pecten e de 07 furos de sondagem realizados pela companhia Anschutz, no Paraguai.

Esta análise possibilitou o estabelecimento de um arcabouço estratigráfico representativo deste intervalo, sendo o mesmo composto por quatro seqüências deposicionais de segunda ordem (senso Vail et al., 1977b), consideradas como do Tipo -1 e definidas como: Seqüencia Ordoviciana, Seqüência Silurina, Seqüência Eo-Devonina e Seqüência Meso/Neo-Devoniana. A análise do teor de carbono orgânico total realizada, visando configurar as superfícies de máxima inundação das quatro seqüências propostas, indicou os maiores valores para a superfície eo-frasniana, quando ocorreria a máxima expansão da bacia.

O estudo geocronológico dos sedimentos da Formação lapó, bem como o refinamento bioestratigráfico dos sedimentos da Formação Vila Maria, possibilitaram a definição do posicionamento temporal dos eventos glaciais atuantes no Gondwana ocidental.

A distribuição regional dos sedimentos permitiu identificar que a Bacia do Paraná, no intervalo de tempo enfocado, teve sua evolução marcada por dois compartimentos estruturais distintos, posicionados a norte e a sul de uma zona estrutural balizada pelo Alinhamento Guapiara. 
Este estudo demonstrou, também, que os sedimentos ordovicianos da Bacia do Paraná tiveram sua deposição controlada pelo Lineamento Transbrasiliano a partir da geração de um sistema rift no interior desse lineamento, inicialmente induzido por intrusões graníticas de idade Cambro-Ordoviciana.

A história evolutiva da Bacia do Paraná, apresentada neste trabalho, demonstra que a propagação dos esforços compressivos gerados na borda da placa, em forma de esforços transtensionais, ao longo do lineamento, somada à carga sedimentar e ao resfriamento das massas intrudidas conduziram a subsidência inicial desta bacia. 


\section{ABSTRACT}

This investigation concerns the tectono-sedimentary evolution of the Paraná Basin from the Ordovician to the Devonian. The study was based on the integrated analysis of a large database including sedimentology, stratigraphy, biostratigraphy and geochemistry. The data have been collected from wells and outcrops in the Alto Garças Sub-basin and western Paraguay.

Four Type-1 stratigraphic sequences are recognized by this study, namely: the Ordovician Sequence, the Silurian Sequence, the Early Devonian Sequence and the Middle / Late Devonian Sequence. Total organic carbon analyses, carried out in order to identify maximum flooding surfaces related to those sequences, indicate that highest values were attained during the early Frasnian, when the maximum basin expansion is also recorded.

The geochronologic study of the lapó Formation sediments, along with a refinement of the Vila Maria Formation biostratigraphy, permits a more accurate dating of glacial episodes recorded in western Gondwana.

The regional distribution of sediments demonstrates that two different structural compartments are present in the Paraná Basin during the investigated time interval. The northern tectono-sedimentary compartment is represented by Alto Garças Sub-basin, its southern equivalent being the Apucarana Sub-basin. They are separated from each other by the Guapiara Lineament. This study also shows that the Transbrazilian Lineament controlled the Ordovician sedimentation by means of a rift system coincident with the lineament, originated by the emplacement of intrusive granite bodies of early Cambrian-Ordovician age. In conclusion, early subsidence phases of the Paraná basin were conditioned by: (1) transtensive reactivations of the Transbrazilian Lineament in response to compressive efforts directed against the western border of Gondwana, in addition to (2) increasing sedimentary load and (3) cooling of intrusive granite masses. 


\section{LISTA DE FIGURAS}

Fig. 01 - Localização das regiões estudadas nesta pesquisa, no Brasil

Fig. 02 - Aspectos sedimentológicos observados nas regiões de Aquidauana (MS), Rio Negro (MS) e Rio Verde de Mato Grosso (MS).

Fig. 03 - Perfis sedimentológicos observados nas regiões de Aquidauana

(MS) e Rio Verde de Mato Grosso (MS) 18

Fig. 04(a, b) - Aspectos sedimentológicos observados nas regiōes de Rio Negro (MS) e Rio Verde de Mato Grosso (MT)

Fig. 05 - Aspectos sedimentológicos observados na região de São Lourenço de Fátima (MT)

Fig. 06 - Perfis sedimentológicos observados na região de Săo Lourenço de Fátima (MT).

Fig. 07 - Perfil sedimentológico na região da Cachoeira Degrau e Andorinha, Chapada dos Guimarães (MT).

Fig. 08 - Perfil sedimentológico na região de Dom Aquino (MT).

Fig. 09 - Perfis sedimentológicos observados na Fazenda Sete de Setembro, região de Canarana (MT) 
Fig. 10 - Perfis sedimentológicos observados na Serra do Roncador, região de Canarana (MT)

Fig. 11 - Perfis sedimentológicos observados na região de

Paranatinga (MT).

Fig. 12 - Perfis sedimentológicos envolvendo os sedimentos da Formação

Vila Maria na região de Nova Xavantina (MT)

Fig. 13 - Perfis sedimentológicos realizados no domínio da Serra Azul, região de Vale dos Sonhos (MT). .55

Fig. 13d - Perfil sedimentológico realizado no domínio da Serra Azul, região de Vale dos Sonhos (MT). .56

Fig. 14 - Perfis sedimentológicos envolvendo os sedimentos da Formação Vila Maria na região de Barra do Garças (MT). 60

Fig. 15 - Aspectos sedimentológicos do Membro Médio da Formação Ponta Grossa, observados na região de General Carneiro (MT). 62

Fig. 16 - Perfis sedimentológicos observados na região do Domo de Araguainha e no Município de Pedra Branca (MT) 67

Fig. 17 - Perfil sedimentológico realizado na cidade de Amorinópolis (GO), envolvendo o contato entre as formações Furnas e Ponta Grossa. 73

Fig. 18 - Perfil sedimentológico realizado na cidade de Amorinópolis (GO), envolvendo os sedimentos do Membro Médio da Formação Ponta Grossa. 
Fig. 19 - Aspectos sedimentológicos da seção devoniana, observados na rodovia BR-158, entre as cidades de Piranhas (GO)

e Caiapônia (GO). 77

Fig. 20 - Perfis sedimentológicos envolvendo sedimentos pré-devonianos, nas porções brasileira e paraguaia da Bacia do Paraná.

Fig. 21 - Perfis sedimentológicos envolvendo sedimentos da Formação Vila Maria, no sudoeste de Goiás. 81

Fig. 22 - Mapa de localização dos afloramentos estudados na parte paraguaia da Bacia do Paraná.

Fig. 23 - Aspectos sedimentológicos do Grupo Caacupé, observados no

Domínio do Bloco Cordilheira na Republica do Paraguai.

Fig. 24 - Aspectos sedimentológicos do Grupo Itacurubí, observados no

Domínio do Bloco Cordilheira na Republica do Paraguai. .94

Fig. 25 - Mapa de localização dos poços estudados na parte brasileira da Bacia do Paraná. 104

Fig. 26 - Mapa de localização dos poços Assunção 1 e Assunção 2 e dos Furos de sondagem RD-116, RD-115, 269-R1, 269-R3, 269-R4, 268-R1 e 268-R2 106

Fig. 27a - Perfis sedimentológicos realizados em testemunhos do poço 2-AG-1-MT. 108

Fig. 27b - Perfis sedimentológicos realizados em testemunhos do poço 2-AG-1-MT. 109 
Fig. 28a - Perfis sedimentológicos realizados em testemunhos do poço

Fig. $28 \mathrm{~b}$ - Perfis sedimentológicos realizados em testemunhos do poço

2-JA-1-GO

Fig. 29 - Perfil sedimentológico realizado a partir dos testemunhos 17 e 18 do poço 2-RP-1-MT. 116

Fig. 30 - Perfis sedimentológicos realizados em testemunhos do poço 2-TL-1-MT. 118

Fig. 31 - Perfis sedimentológicos realizados em testemunhos dos poços 2-AR-1-SP, 2-RI-1-PR e 2-OL-1-SP. 121

Fig. 32 - Descrição litológica dos furos de sondagem RD-116 e RD-115. .127

Fig. 33 - Seção estratigráfica Chapada dos Guimarães - Poço 2-LA-1-SP 161

Fig. 34 - Seção estratigráfica Poço 2-DO-1-MT - Cachoeira das Perdizes. 165

Fig. 35 - Seção estratigráfica Poço Assunção 1 - Furo RD-115 .169

Fig. 36 - Descrição litológica do furo de sondagem 268-R2.

Fig. 37 - Correlação estratigráfica envolvendo os sedimentos silurianos do furo RD-116 (no Paraguai) e o poço 2-RI-1-PR (no Brasil)

Fig. 38 - Seção estratigráfica Furo 269-R1 - Furo RD-115. 
Fig. 39 - Seção estratigráfica Poço 2-RI-1-PR - Poço 2-AR-1-SP

Fig. 40 - Detalhamento sedimentológico do testemunho 4 do poço

2-AR-1-SP 181

Fig. 41 - Seção" estratigráfica Poço 2-AG-1-MT - Poço 2-TL-1-MT 183

Fig. 42 - Seção estratigráfica entre os poços Assunção 1 e Assunção 2 188

Fig. 43 - Arcabouço Cronolitoestratigráfico discutido na pesquisa 192

Fig. 44 - Mapa de isópacas da Seqüência Ordoviciana. 201

Fig. 45 - Mapa de isópacas da Seqüência Siluriana. 205

Fig. 46 - Mapa de isópacas das seqüências ordoviciana e siluriana 207

Fig. 47 - Valores de carbono orgânico total observados no Furo RD-116. 209

Fig. 48 - Esboço paleogeográfico para a Bacia do Paraná, no tempo Lochkoviano, extraído de Gerrienne et al. (submetido, 1999) 212

Fig. 49 - Valores de carbono orgânico total observados em sedimentos praguianos, no Barreiro Felix, Rio Verde de Mato Grosso (MT) 214

Fig. 50 - Mapa de porcentagem de areia na Formação Ponta Grossa, modificado de Northfleet et al. (1969) 218

Fig. 51 - Valores de carbono orgânico total observados em sedimentos neo-emsianos, na região de Baliza (GO). 219 
Fig. 52 - Valores de carbono orgânico total observados em sedimentos neo-devonianos, na região de Dom Aquino (MT).

Fig. 53 - Diferentes concepções sobre a geologia do embasamento da Bacia do Paraná.

Fig. 54 - Mapa do arcabouço estrutural da Bacia do Paraná. 230

Fig. 55 - Mapa gravimétrico de Bouguer da Bacia do Paraná, extraído de Vidotti et al. (1998). 238

Fig. 56 - Representação esquemática do processo de formação de bacia intracratônica proposto por Klein (1995), modificado de Klein \& Hsui (1987) 


\section{LISTA DE QUADROS E TABELAS}

Quadro 1 - Etapas de campo realizadas para a obtençäo dos dados discutidos na pesquisa..

Quadro 2 - Código de litofácies utilizado nesta pesquisa a partir da conceituação de Miall (1978).

Quadro 3 - Nomenclatura cronoestratigráfica utilizada no trabalho, modificada de Harland et al. (1990).

Tabela 1 - Localização das amostras coletadas em poços da Petrobrás

e Paulipetro 105

Tabela 2 - Esporos e Cryptosporos identificados no furo RD-116 125

Tabela 3 - Esporos e Cryptosporos identificados no furo RD-115 129

Tabela 4 - Esporos e Cryptosporos identificados no poço Assunção 1 , no intervalo entre 2835 e 2775 metros.

Tabela 5 - Esporos e Cryptosporos identificados no poço Assunção 1, no intervalo entre 2365 e 2267,5 metros

Tabela 6 - Lâminas preparadas a partir de amostras coletadas no poço

Assunção 2 133 
Tabela 7 - Lâminas preparadas a partir de amostras coletadas em poços e afloramentos, localizados na parte brasileira da Bacia do Paraná.........135

Tabela 8 - Estágios da evolução diagenética 148

Tabela 9 - Amöstras coletadas visando a datação radiométrica. 156

Tabela 10 - Amostras analisadas por DRX 157 


\section{CAPÍTULO 1 - INTRODUÇĂO}

\section{1 - Aspectos Gerais}

Este trabalho apresenta os resultados obtidos no projeto de pesquisa Análise da Evolução Sedimentar do Paleozóico inferior e médio da Sub-Bacia do Alto Garças, Bacia do Paraná, Brasil, o qual deu suporte ao programa de estudo que foi executado junto ao Programa de Doutorado em Geologia Sedimentar do IG-USP.

$O$ projeto de pesquisa em questão tinha por objetivo a integração de dados estratigráficos e sedimentológicos obtidos a partir da faixa de afloramento do paleozóico inferior e médio da Sub-Bacia do Alto Garças e sua correlação com os dados de subsuperfície, visando o estabelecimento de um arcabouço estratigráfico, e sua representação através de mapas paleogeográficos.

Para alcançar o objetivo geral proposto, foi desenvolvido um conjunto de trabalhos visando atingir as metas (listadas abaixo) estabelecidas no inicio do programa de trabalho.

1) Estender, para todas as áreas do estudo, o arcabouço estratigráfico definido por Pereira (1992), para o intervalo de tempo em questão, no sudoeste de Goiás.

2) Definir em afloramento e nos poços utilizados, superficies de correlação que permitam o estabelecimento de intervalos para a confecção de mapas estratigráficos.

3) Melhorar a definição bioestratigráfica do intervalo, através da coleta sistemática de amostras para a análise palinológica, bem como tentar datar, por métodos diretos, os intervalos estéreis. 
4) Promover uma análise sedimentológica detalhada de afloramentos significativos, objetivando a definição dos sistemas deposicionais preservados.

Essas metas foram perseguidas ao longo da pesquisa, colocandose, então, como objetivos mais específicos deste trabalho: 1) elaborar um modelo geológico visando o entendimento da implantação da Bacia do Paraná; 2) estabelecer um arcabouço estratigráfico de $2^{\circ}$ ordem, com base na caracterização de seqüências deposicionais e seus tratos de sistema, através da elaboração de seções estratigráficas em afloramento e subsuperfície; 3 ) detalhar as superfícies limitantes das seqüências a partir da análise dos perfis compostos dos poços e das relações de contato dos sedimentos em afloramentos e definir as superfícies de máxima inundação em termos geoquímicos; 4) promover um refinamento do zoneamento bioestratigráfico do intervalo de estudo, em parceria com especialistas colaboradores, visando facilitar as correlações estratigráficas; 5) buscar datar, por método direto ou indireto, horizontes estratigráficos considerados estéreis ou com informações de idade conflitantes; 6) mapear a distribuição dos estratos que preenchem as seqüências e caracterizar os sistemas deposicionais envolvidos na sedimentação; 7) definir os eventos que modificaram o registro deposicional preservado e 8) estabelecer uma história evolutiva, para as áreas estudadas, no intervalo de tempo entre o Ordoviciano e o Devoniano.

\section{2 - Aspectos Metodológicos}

Nos últimos 20 anos, ocorreu uma revolução no modelo de análise estratigráfica. A partir dos trabalhos pioneiros de Vail et al. (1977a) criaram-se as bases do que hoje chamamos de Estratigrafia de Seqüência.

A Estratigrafia de Seqüência vem sendo amplamente utilizada pela comunidade geológica desde o final da década de oitenta. Nesta época, ocorreu a publicação de seus conceitos básicos (Wilgus et al., 1988) como modelo de 
análise para uma larga base de dados, incluindo dados sísmicos convencionais e de alta resolução, perfis elétricos de poços, afloramentos, testemunhos, dados paleontológicos e geoquímicos (Posamentier \& Allen, no prelo).

A Estratigrafia de Seqüências é definida como o estudo das relações das rochas dentro de um arcabouço cronoestratigráfico, no qual a sucessão de rochas é cíclica e composta por unidades estratais geneticamente relacionadas. Entende-se por unidades estratais as seqüências e os tratos de sistemas (Posamentier et al.,1988).

As sequências são definidas como uma sucessão de estratos geneticamente relacionados, limitadas no seu topo e base por superfícies de erosão ou não deposição (discordâncias), e suas concordâncias relativas, sendo os tratos de sistemas definidos como uma associação de sistemas deposicionais contemporâneos (Posamentier et al.,1988).

Este novo contexto da análise estratigráfica insere-se no que modernamente se entende por Análise de Bacias, onde a área de estudo é analisada dentro de uma visão holística, de forma a compreender a inter-relação entre os processos de formação, preenchimento e deformação da bacia.

Assim, dentro desta nova visão para se compor o arcabouço estratigráfico, são definidas superfícies que possam representar limites de seqüencias, no sentido de Vail et al. (1977a), e que sejam mapeáveis em toda a bacia.

Objetivando facilitar a identificação dessas superficies e 0 estabelecimento de seqüências de $2^{\circ}, 3^{\circ}$ e $4^{\circ}$ ordem, que são unidades estratigráficas com maior poder de correlação, são definidos arranjos de parasseqüências (senso; Van Wagoner, 1990) em perfis sedimentológicos 
verticais. No caso de perturações, estes arranjos são estabelecidos a partir do registro de Raio Gama e de Resistividade.

$\mathrm{Na}$ escala de afloramento, a análise estratigráfica se faz através da descrição de perfis sedimentológicos detalhados, onde se estabelecem as sucessões verticais de fácies (senso Walker, 1990), definindo ciclos de afinamento normal ou inverso, limitados por superfícies de inundação.

Ainda nesta escala de trabalho, em afloramentos com boa preservação e continuidade lateral, podem ser mapeadas as principais superfícies deposicionais, de forma a estabelecer conjuntos genéticos definidos por Miall (1985) como elementos arquiteturais. Esses conjuntos são compostos por litofácies, que são descritas com base nas estruturas primárias e na geometria externa. Esses procedimentos desenvolvidos nos afloramentos são a base da interpretação dos ambientes e sistemas deposicionais no atual cenário da análise estratigráfica.

Para a preparação de mapas estratigráficos e paleogeográficos, existe a necessidade de se diagnosticar superfícies de correlação, admitidas como isócronas, que limitam os intervalos a serem mapeados. Este procedimento requer um arcabouço bioestratigráfico confiável, que pode ser obtido através da coleta sistemática de amostras para análise palinológica.

A análise palinológica permite a definição das idades relativas utilizando-se as assembléias palinológicas observadas e a comparação das mesmas com as cartas de biozoneamento internacionais.

A aplicação da Estratigrafia de Seqüências na análise estratigráfica vem sendo largamente utilizada, em função da mesma ser um método de estudo que possibilita um refinamento na correlação estratigráfica de poços, criando 
condições para o estabelecimento de correlações temporais e faciológicas de alta resolução.

Como já visto, a base teórica das correlações de alta resolução foi definida a partir dos estudos estratigráficos em perfis de poços, testemunhos $e$ afloramentos (Vän Wagoner et al., 1990).

Assim, neste novo contexto da análise estratigráfica, o desenvolvimento deste estudo envolveu a realização de etapas de campo, no bojo de um projeto de pesquisa mais amplo, e a análise de poços e furos de sondagem. Nas etapas de campo (Quadro I) foram coletados inúmeros dados onde se incluem: o levantamento de perfis sedimentológicos de detalhe, a cobertura fotográfica de toda a seção aflorante, a coleta sistemática de amostras voltadas para a análise palinológica e geoquímica, a amostragem visando alguns estudos petrográficos e, também, a preparação de seções geológicas regionais para o posicionamento cartográfico da seção aflorante.

\section{ETAPAS DE CAMPO}

ETAPA 1

PERCURSO: RIO - ASSUNÇÃO (PARAGUAI) - SAN JUAN (ARGENTINA) - RIO. PERÍODO: JULHO DE 1993

OBJETIVO: Observação de rochas silurianas em afloramentos na região de Assunção e San Juan.

ETAPA 2

PERCURSO: RIO - JAGUARIAÍVA (PR) - RIO.

PERÍODO: SETEMBRO DE 1993

OBJETIVO: Visita à faixa de afloramentos siluro-devonianos no bordo Leste da Bacia do Paraná (flanco norte do Arco de Ponta Grossa).

\section{ETAPA 3}

PERCURSO: RIO - IPORÁ (GO) - BARRA DO GARÇAS (MT) - RONDONÓPOLIS(MT) - COXIM (MS) RIO.

PERIODO: ABRIL DE 1994

OBJETIVO: Visita à faixa de afloramentos do Siluro-Devoniano na porção setentrional da Bacia do Paraná. 


\section{ETAPA 4}

PERCURSO: RIO - RIO VERDE (MS) - COXIM (MS) - RONDONÓPOLIS (MT) - CHAPADA DOS GUIMARÄES (MT) - PARANATINGA (MT) - RIO PERIODO: FEVEREIRO DE 1995

OBJETIVO: Visita à faixa de afloramentos do Siluro-Devoniano na porção setentrional da Bacia do Paraná.

\section{ETAPA 5}

PERCURSO: RIO - IPORÁ (GO) - BARRA DO GARÇAS (MT) - NOVA XAVANTINA (MT) - CANARANA (MT) - PARANATINGA (MT) - RIO PERIODO: JULHO / AGOSTO 1995

OBJETIVO: Visita aos afloramentos do Siluro-Devoniano na porção setentrional da Bacia do Paraná e na porção Sul da Bacia do Parecis.

\section{ETAPA 6}

PERCURSO: RIO - ITARARÉ(SP) - ITAPEVA (SP) - JAGUARIAIVA (PR) - TIBAGI (PR) - PONTA GROSSA (PR) - RIO

PERIODO: JULHO / AGOSTO DE 1995

OBJETIVO: Visita à faixa de afloramentos siluro-devonianos no bordo Leste da Bacia do Paraná.

\section{ETAPA 7}

PERCURSO: RIO - ALTO ARAGUAIA (MT) -BARRA DO GARÇAS (MT) - NOVA XAVANTINA (MT) CHAPADA DOS GUIMARÃES (MT) - RIO PERIODO: MAIO DE 1996

OBJETIVO: Verificação da faixa de afloramentos Siluro-Devonianos na região de Serra Azul e Serra do Roncador -MT.

\section{ETAPA 8 \\ PERCURSO: RIO - ASSUNÇÃO (PARAGUAI) - RIO PERIOODO: MAIO DE 1997}

OBJETIVO: Visita aos afloramentos das unidades ordovicio-silurianas associadas ao Bajo de San Pedro.

\section{ETAPA 9}

PERCURSO: RIO - AQUIDAUANA (MS) - RONDONÓPOLIS (MT) - BOM JARDIM DE GOIÁS (GO) RIO

PERIOODO: AGOSTO DE 1997

OBJETIVO: Observação de afloramentos das unidades ordovicio-silurianas e devonianas na região oeste da Bacia do Paraná e no sudoeste de Goiás.

\section{ETAPA 10}

PERCURSO: RIO - PICOS(PI) - FLORIANO(PI) - RIO

PERIOODO: DEZEMBRO DE 1997

OBJETIVO: Coleta de dados na faixa de afloramentos do Siluro-Devoniano na Bacia do Parnaíba.

ETAPA 11

PERCURSO: RIO - BARRA DO GARÇAS (MT) - SONORA (MS) - RIO PERIOODO: DEZEMBRO DE 1998

OBJETIVO: Observação de afloramentos das unidades ordovicio-silurianas e devonianas na região nordeste e oeste da Bacia do Paraná.

Quadro 1 - Etapas de Campo realizadas ao longo do Projeto PADCTIUERJ/FINEP ( $n^{\circ}$ 65.91.0373.00) para a obtenção dos dados discutidos nesta pesquisa. 
Dentro do arcabouço de dados, a análise dos perfis sedimentológicos, obtidos em afloramentos e testemunhos, juntamente com o auxílio da cobertura fotográfica dos afloramentos, possibilitam estabelecer os processos deposicionais dominantes, de forma a inferir os ambientes de sedimentação preservados.

A partir da análise dos perfis sedimentológicos foram caracterizadas as litofácies descritas no quadro abaixo (Quadro 2).

\begin{tabular}{|c|c|c|}
\hline código & L.JTOFÁCIES & DESCRIÇÃO \\
\hline $\mathrm{Dm}$ & Diamictito maciço & $\begin{array}{l}\text { Homogêneo, desorganizado, suportado por matriz, matriz } \\
\text { areno-argilosa, mal selecionada, polimítico, seixos de até } 30 \mathrm{~cm} \text {, } \\
\text { facetados a subarredondados, raramente estriados. }\end{array}$ \\
\hline Fmi & $\begin{array}{l}\text { Folhelho / Siltito maciço a } \\
\text { laminado }\end{array}$ & $\begin{array}{l}\text { Argilito maciço a debilmente laminado, fratura conchoidal, pouco } \\
\text { bioturbado, fossilifero. Coloração negra a vermelha arroxeada. }\end{array}$ \\
\hline Fid & $\begin{array}{l}\text { Folhelho / Arenito muito fino } \\
\qquad \begin{array}{l}\text { - várvico }\end{array}\end{array}$ & $\begin{array}{l}\text { Ritmito composto por pares milimétricos de folhelhos e arenitos } \\
\text { em contato abrupto entre si. Seixos caídos, dispersos, com até } \\
20 \mathrm{~cm} \text {. Seixos de composição variada, facetados e estriados. }\end{array}$ \\
\hline Fwxl & Siltito / Arenito muito fino & $\begin{array}{l}\text { Siltito inter-estratificado com arenito muito fino, geometria } \\
\text { lenticular, laminação cruzada por onda e plano-paralela. }\end{array}$ \\
\hline Sx & $\begin{array}{l}\text { Arenito com estratificação } \\
\text { cruzada }\end{array}$ & $\begin{array}{l}\text { Arenito médio a grosso estratificação cruzada planar ou } \\
\text { acanalada, com seixos. }\end{array}$ \\
\hline Sr & Arenito com ripple & Arenito fino/médio/grosso com ripple drift cross lamination. \\
\hline $\mathrm{Sm}$ & Arenito maciço & Arenito médio, maciço com geometria de lentes extensas. \\
\hline Sp & $\begin{array}{l}\text { Arenito com estratificação } \\
\text { cruzada planar }\end{array}$ & $\begin{array}{l}\text { Arenito fino a médio com estratificaçăo cruzada planar, } \\
\text { centimétrica a métrica. }\end{array}$ \\
\hline St & $\begin{array}{l}\text { Arenito com estratificação } \\
\text { cruzada acanalada }\end{array}$ & $\begin{array}{l}\text { Arenito médio a grosso, com estratificação cruzada acanalada, } \\
\text { centimétrica. }\end{array}$ \\
\hline Shcs & $\begin{array}{l}\text { Arenito com estratificação } \\
\text { cruzada por onda }\end{array}$ & $\begin{array}{l}\text { Arenito fino com estratificação cruzada por onda, centimétrica a } \\
\text { métrica. }\end{array}$ \\
\hline Gm & Conglomerado & $\begin{array}{l}\text { Conglomerado maciço a debilmente organizado, suportado por } \\
\text { clasto a suportado por matrix. }\end{array}$ \\
\hline Gp & $\begin{array}{l}\text { Conglomerado com } \\
\text { estratificação cruzada } \\
\text { planar }\end{array}$ & $\begin{array}{l}\text { Conglomerado organizado, suportado por clasto a suportado por } \\
\text { matrix, com estratificação cruzada planar, centimétrica a } \\
\text { métrica. }\end{array}$ \\
\hline Gt & $\begin{array}{l}\text { Conglomerado com } \\
\text { estratificaçāo cruzada } \\
\text { acanalada }\end{array}$ & $\begin{array}{l}\text { Conglomerado organizado, suportado por clasto a suportado por } \\
\text { matrix, com estratificação cruzada acanalada, centimétrica a } \\
\text { métrica. }\end{array}$ \\
\hline
\end{tabular}

Quadro 2 - Código de Litofácies utilizado nesta pesquisa a partir da conceituação de Miall (1978). 
Com base nas amostras coletadas para o estudo palinológico e geoquímico, foi possível estabelecer correlações estratigráficas entre as seções, bem como melhor caracterizar as superficies estratigráficas definidas como superfícies de inundação.

O segundo foco da pesquisa envolveu o estudo sistemático das informações dos poços perfurados, de forma a possibilitar a correlação dos dados obtidos em superfície com aqueles analisados em subsuperfície.

Foi realizado o estudo detalhado dos poços estratigráficos; 2-AG-1MT (Alto Garças), 2-CG-1-MT (Campo Grande), 2-TL-1-MT (Três Lagoas), 2-AM1-MS (Amambai), 2-DO-2-MT (Dourados), 2-RP-1-MT (Ribas do Rio Pardo), 2-RA1-MS (Rio Aporé), 2-AN-1-PR (Altonia), 2-JA-1-GO (Jatai), 2-RI-1-PR (Rio Ivaí), 2LA-1-SP (Lagoa Azul), 2-AR-1-SP (Araçatuba), 2-OL-1-SP (Olímpia) e do poço 3CB-3-SP (Cuiabá Paulista), na área brasileira da Bacia do Paraná, como também, o estudo dos poços Assunção I, Assunção II e dos furos de sondagem RD-116, RD-115, 268-R1, 268-R2, 269-R1, 269-R3 e 269-R4, localizados na área paraguaia da bacia.

A análise dos poços incluiu a coleta de amostras para a análise palinológica de testemunhos e calha, visando definir a idade dos sedimentos (ver Quadro 3); a coleta de amostras de testemunhos para a análise geoquímica; a inspeção de testemunhos e a análise dos perfis dos poços. A análise dos perfis de Raio Gama e de Potencial Expontâneo possibilita a definição de ciclos de afinamento ou engrossamento granulométrico para o topo, bem como a identificação de superfícies de descontinuidade e de superfícies associadas aos eventos de máxima inundação.

A metodologia que foi aplicada permitiu a definição temporal dos ambientes de sedimentação diagnosticados nos afloramentos, possibilitando 0 
posicioriamento estratigráfico dos mesmos. Dessa forma, com o auxílio das seções geológicas aflorantes e do estudo dos poços, é possível estabelecer o arranjo paleogeográfico de um determinado momento do tempo geológico. Tal arranjo é, em essência, o objetivo final da análise estratigráfica. 


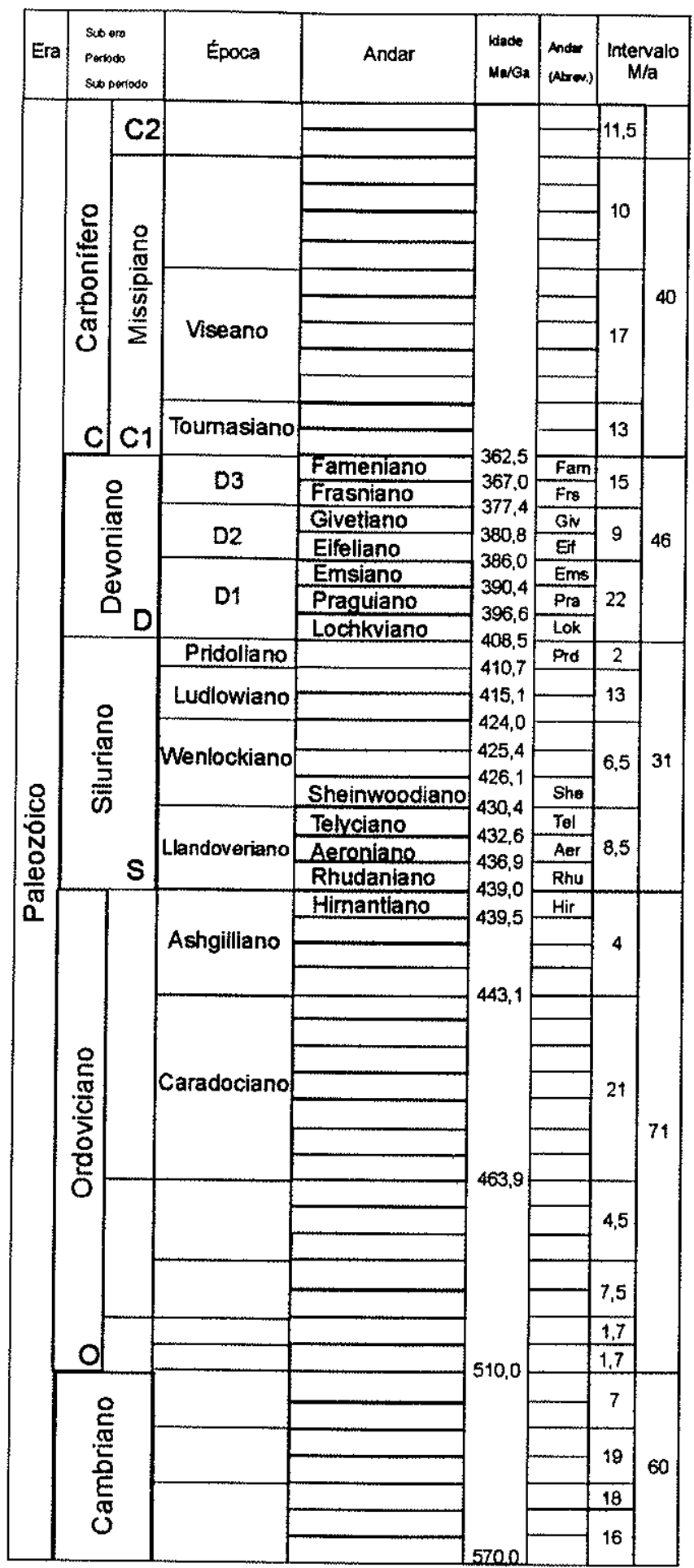

Quadro 3 - Nomenclatura cronoestratigrafica utilizada no trabalho (modificada de Harland et al., 1990). 


\section{Capítulo 2 - Arcabouço de Dados}

\section{1 - Dados Geológicos obtidos em Afloramentos}

Os dados geológicos, provenientes de afloramentos, foram levantados a pärtir de uma ampla área de exposição que envolve três diferentes estados brasileiros (Fig. 01) e parte do território paraguaio (Fig. 22). Neste trabalho de levantamento geológico, que tem por base 19 municípios brasileiros, foram realizados perfis sedimentológicos de detalhe nas seções aflorantes mais significativas; coleta de material para análise palinológica e geoquímica de localidades favoráveis; seções geológicas em estradas e uma completa cobertura fotográfica dos afloramentos visitados.

\subsection{1 - Dados de campo obtidos no estado de Mato Grosso do Sul}

No estado de Mato Grosso do Sul foram levantados perfis estratigráficos de detalhe e seções geológicas nos municípios de Aquidauana, Cipolândia, Rio Negro, Rio Verde de Mato Grosso, Coxim, Pedro Gomes e Sonora.

\subsubsection{1 - Região de Aquidauana (MS) e Cipolândia (MS)}

Na região dos municipios de Aquidauana (MS) e Cipolândia (MS) foram levantadas quatro seções geológicas envolvendo sedimentos associados às formações Furnas e Vila Maria.

A primeira seção, levantada a cerca de $12 \mathrm{Km}$ da cidade de Aquidauana $\left(20^{\circ} 21,18^{\prime} \mathrm{S}\right.$ e $\left.55^{\circ} 14,86^{\prime} \mathrm{W}\right)$, na Rodovia Transpantaneira (BR-419), é composta por um conjunto de arenitos de coloração branca, formado por 


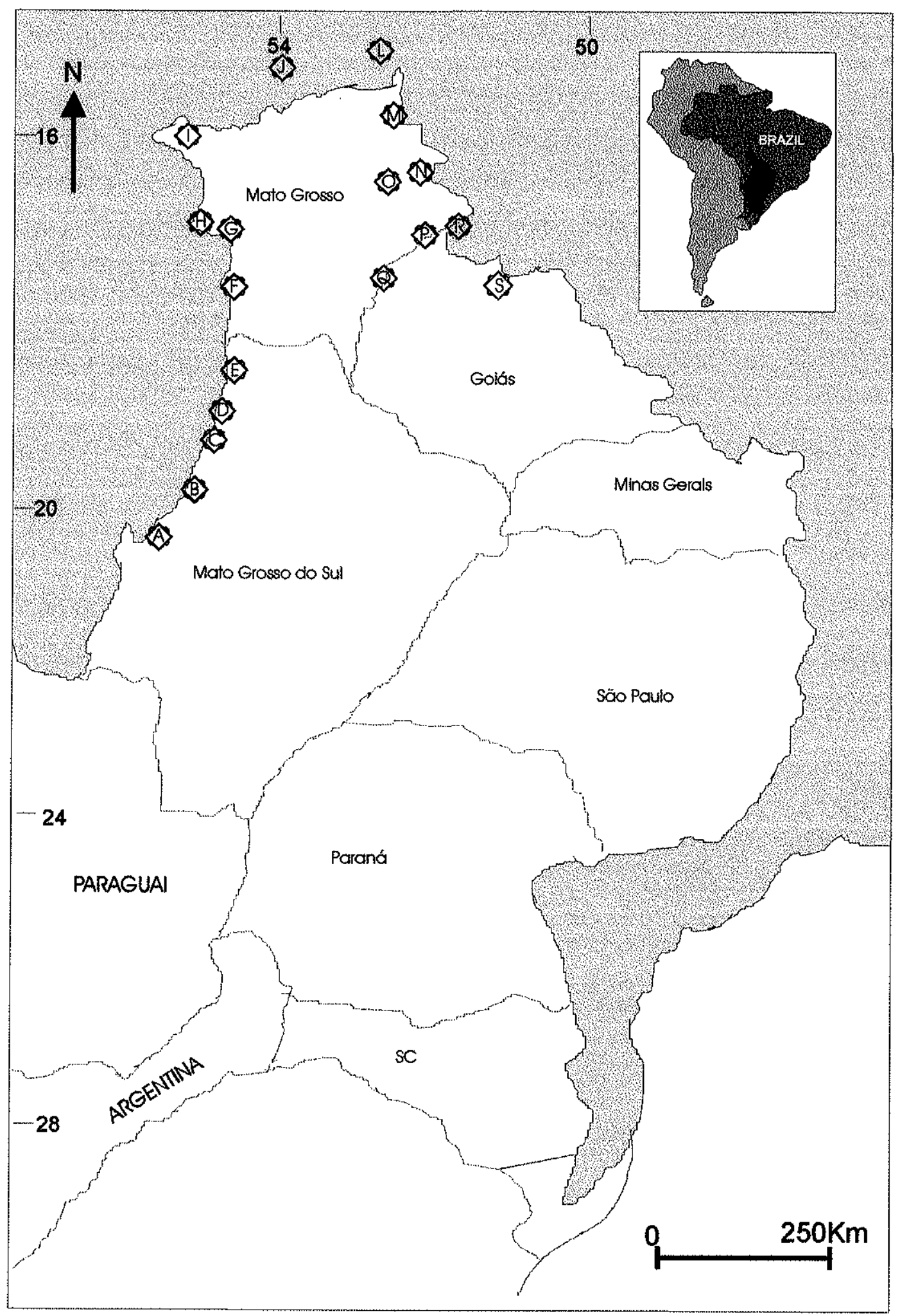

Fig. 01 - Localizaçăo das regiöes estudadas nesta pesqulsa no Brasit:

Estaco de Moto Grosso do sul:

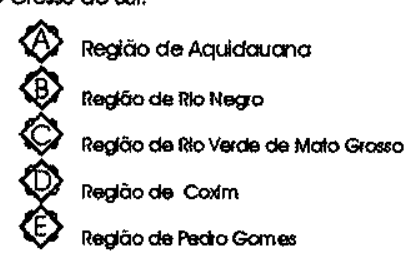

Estodo de Mato Grosso:

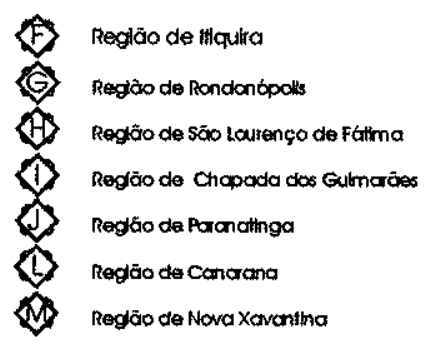

(1) Regiōo de Barra do Garças

(Q) Regäo de Genera cometo

(P) Regkio de Pecka Branca

(6) Regá̃o de Alto Arcguata

Estocos de Cakts

(1) Regiōo de 8ctza

(S) Regläo de Amonnópolss 
espessos pacotes arenosos com geometria sigmoidal. Ocorrem arenitos com granulometria variando de fina à média, portadores de estratificação cruzada planar (Sp) e estratificação cruzada tangencial à base. Intercalados a estes corpos de arenitos ocorrem pacotes tabulares, de granulometria mais fina, portadores de estratificação cruzada por onda (Hummocky cross stratification - HCS). Estes arenitos estão presente em forma de conjuntos tabulares isolados na paisagem, entre as cotas de 200 e 250 metros.

Na mesma rodovia, $5 \mathrm{Km}$ à frente, em uma outra seção $\left(20^{\circ} 19,35^{\prime} \mathrm{S}\right.$ e $\left.55^{\circ} 44,91^{\prime} \mathrm{W}\right)$, este conjunto sedimentar deposita-se diretamente sobre o embasamento, constituído por filitos deformados do Grupo Cuiabá. Estes arenitos são mapeados como pertencentes à Formação Furnas, nos mapas regionais (RADAMBRASIL, volume 28; Araújo et al., 1981). Contudo, não são observadas relações estratigráficas para o topo desta seção. Dessa forma, não se pode excluir a possibilidade destes arenitos estarem posicionados estratigraficamente abaixo da Formação Vila Maria.

No mapa geológico editado pelo Projeto RADAMBRASIL vol 27 (Del'Arco et al., 1982) está cartografada a Formação Coimbra, que foi originalmente definida por Oliveira \& Moura (1944) e posteriormente descrita por Corrêa et al. (1979). Esta unidade possui uma área de ocorrência reduzida, sendo a mesma observada em um conjunto de morros alinhados, de direção geral $\mathrm{N} 30^{\circ} \mathrm{W}$, a partir da localidade tipo em Forte Coimbra (MS), Rio Paraguai. Esta formação é composta por arenitos róseos, de granulação grosseira, de composição dominantemente quartzosa, com grãos angulosos a subarrendondados, portadores de estratificação plano-paralela e estratificação cruzada planar. Ocorrem, também, níveis conglomeráticos com grânulos e seixos. A Formação Coimbra é correlacionada com os arenitos "El Carmen" da Bolívia, que são considerados de idade Siluriana, com base no conjunto fossilifero analisado por Lange (1955), estando a mesma assentada em discordância angular 
e erosiva, sobre os calcários dolomíticos da Formação Bocaina (Corrêa et al., 1979).

Assim, torna-se necessário analisar a possibilidade de correlação entre o conjunto arenoso observado próximo a Aquidauana com os arenitos associados à Formação Coimbra.

Na mesma região de Aquidauana, no município de Cipolândia (MS), Gesicki (1996) descreve, na localidade de n. ${ }^{\circ} 134$ de seu mapa de pontos, a presença de sedimentos (diamictitos) associados à seção sedimentar pré-Furnas. Na mesma região, na localidade da fazenda Concremix, Assine et al. (1998 b) descrevem a presença de rochas associadas ao Grupo Rio Ivaí.

$\mathrm{Na}$ etapa de campo realizada em julho de 1997, foi levantada uma seção de detalhe na estrada vicinal, paralela ao Rio Taboco, que faz a ligação entre a rodovia Transpantaneira e a Vila de Cipolândia. Nesta seção, no primeiro ponto analisado ( $20^{\circ} 07,39^{\prime} \mathrm{S}$ e $55^{\circ} 32,45^{\prime} \mathrm{W}$ ), observa-se 3 metros de diamictito em discordância com os filitos do Grupo Cuiabá. Estes diamictitos gradam para uma sucessão sedimentar, com cerca de 50 metros de espessura, de cor vermelha, composta por conglomerados e arenitos conglomeráticos (Fig. 2A). O segundo ponto da seção $\left(20^{\circ} 06,76^{\prime} \mathrm{S}\right.$ e $\left.55^{\circ} 31,83^{\prime} \mathrm{W}\right)$ ocorre em um fundo de vale, na mesma cota geográfica dos diamictitos e arenitos. Neste ponto, observase um pacote de 2 metros de siltito cinza-esverdeado, laminado e com intercalações de níveis de arenito muito fino com HCS. Na continuidade desta seção, 65 metros acima $\left(20^{\circ} 05,75^{\prime} \mathrm{S}\right.$ e $\left.55^{\circ} 30,83^{\prime} \mathrm{W}\right)$, são observados arenitos de coloração branca, finos e médios, com laminação. Nesta seção não está registrado o contato entre os siltitos cinza e os arenitos de coloração branca. 


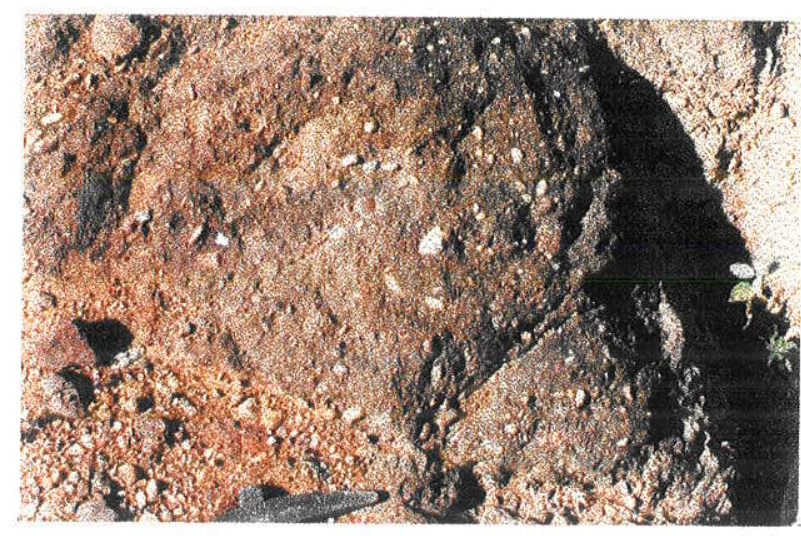

$2 \mathrm{~A}$

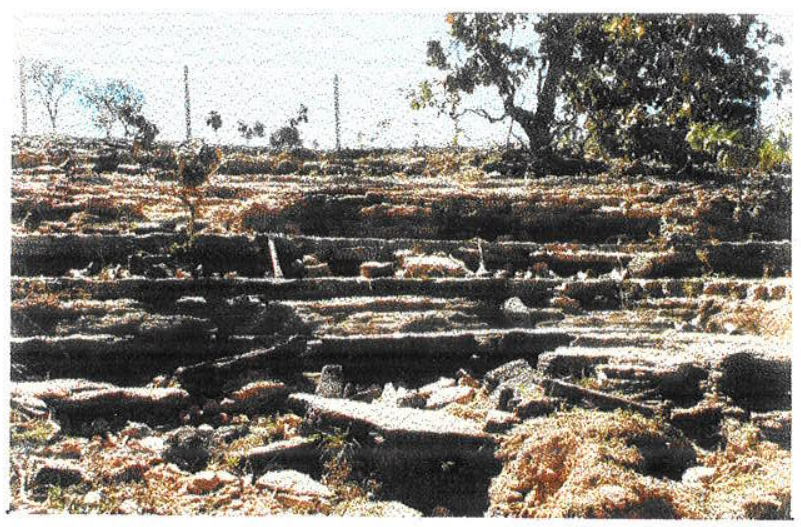

$2 \mathrm{C}$

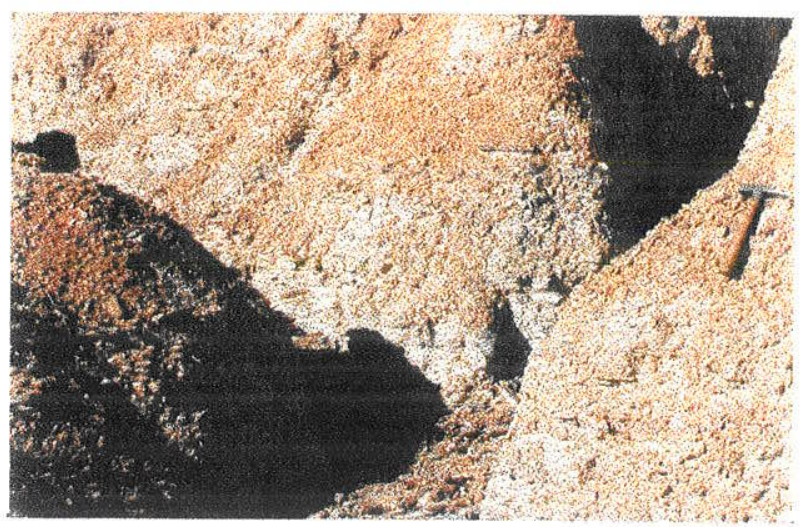

2B

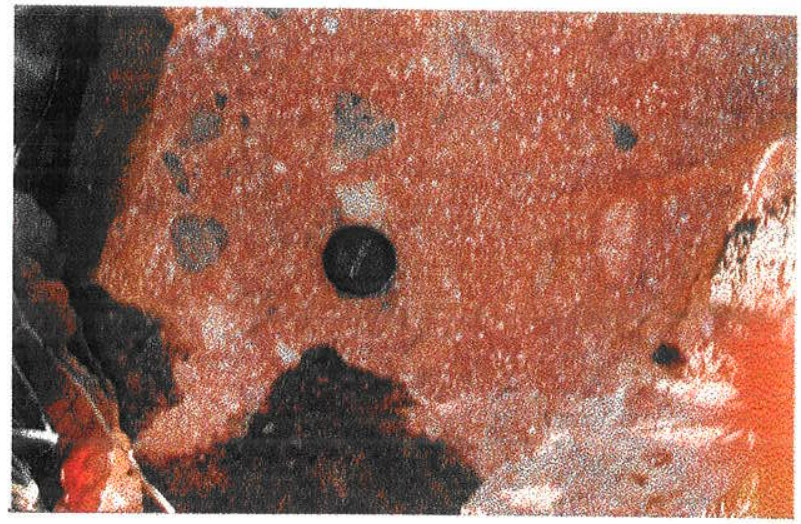

2D

Fig. 02 - Aspectos sedimentológicos observados nas regiões de Aquidauana (MS), Rio Negro (MS) e Rio Verde de Mato Grosso (MS).

A - Diamictito, em contato com o Grupo Cuiabá, na região de Cipolândia $\left(20^{\circ} 07,39^{\prime}\right.$ S e $55^{\circ}$ $32,45^{\prime} \mathrm{W}$ )

B - Siltito laminado com intercalações de níveis de arenito muito fino com $\mathrm{HCS}$, na região de Cipolândia $\left(20^{\circ} 06,76\right.$ 'S e $55^{\circ} 31,83^{\prime}$ W), associado à Formação Vila Maria

C - Arenito fino com HCS e intercalações de níveis de siltito laminado, na região de Rio Negro ( $19^{\circ} 20,46^{\prime}$ 'S e $\left.55^{\circ} 03,62^{\prime} \mathrm{W}\right)$, associado à Formação Vila Maria.

D - Conglomerado suportado por matriz (litofácies $\mathrm{Gm}$ ) de coloração vermelha, próximo a Rio Verde de Mato Grosso $\left(18^{\circ} 44,184^{\prime}\right.$ 'S e $\left.54^{\circ} 51,72^{\prime} \mathrm{W}\right)$, associado à Formação Aquidauana 
A definição das unidades envolvidas nesta seção requer cautela, uma vez que as relações de contato não são nítidas. É possível identificar a fácies pelítica da Formação Vila Maria, subjacente à Formação Furnas nesta seção, embora este contato não seja observado diretamente. Outro aspecto duvidoso é a relação entre os siltitos associados à Formação Vila Maria e o conjunto arenoso composto pelo diamictito e arenitos. No flanco oeste da escarpa cortada pela seção, ocorre uma monótona sucessão de arenitos e conglomerados até o topo da escarpa. Porém, no vale imediatamente após a escarpa, ocorrem siltitos associados à Formação Vila Maria (Fig.02B), que são sucedidos por arenitos da Formação Furnas. Assim, aparentemente, existe um controle estrutural nesta seção que pode estar sendo exercido pela falha do Taboco mapeada no local. Dessa forma, o conjunto arenoso poderia estar associado à Formação Aquidauana, de forma alternativa a um posicionamento estratigráfico do mesmo abaixo dos siltitos associados à Formação Vila Maria.

Nesta mesma estrada vicinal, rodovia Transpantaneira para a vila de Cipolândia, próximo à sede da Fazenda Naturana ( $20^{\circ} 04,87^{\prime} \mathrm{S}$ e $55^{\circ} 29,62^{\prime} \mathrm{W}$ ), foi observada uma pequena seção com 10 metros de espessura (Fig. 03A), onde pode ser visualizado um contato nítido entre arenitos com estratificação cruzada planar (Sp), aparentemente associado à Formação Furnas e sedimentos pelíticos com HCS (fácies FWXI), da Formação Vila Maria (Litofácies III; senso Pereira, 1998). No entanto, não foram observadas feições erosivas no contato entre os arenitos com os siltitos. Dessa forma, existe a possibilidade dos arenitos do topo desta seção, definidos como sendo da Formação Furnas, estarem associados à litofácies IV, da Formação Vila Maria, senso Pereira (1998).

\subsubsection{2 - Região de Rio Negro (MS)}

$\mathrm{Na}$ continuidade dos trabalhos de campo de julho de 1997 foi realizada uma seção geológica ao longo da estrada vicinal que faz a ligação entre 
a cidade de Rio Negro e a rodovia Transpantaneira. Nos mapas geológicos publicados (Corrêa et al., 1979 e Del'Arco et al., 1982), as rochas observadas ao longo desta seção são mapeadas como pertencentes à Formação Furnas. Contudo, a análise de campo possibilitou a definição de um conjunto sedimentar composto por uma sucessão de siltitos intercalados com arenitos finos com HCS (fácies Fwxl), que foram associados à litofácies III da Formação Vila Maria.

Nesta estrada vicinal, na entrada da Fazenda Sombra da Serra $\left(19^{\circ}\right.$ $20,25^{\prime}$ S e $55^{\circ} 03,35^{\prime} \mathrm{W}$ ), pode ser observada a relação de contato entre sedimentos finos (siltitos / folhelhos), ainda não diagnosticados na literatura, em contato com arenitos médios a grossos, de coloração branca, com estratificação cruzada planar $(S p)$. Esta pequena seção é interpretada como o registro da relação de contato por falha entre as Formações Vila Maria e Furnas. Continuando nesta estrada em direção ao Pantanal, são identificadas excelentes exposições de sedimentos associadas à litofácies III da Formação Vila Maria (Fig. 02C) $\left(19^{\circ} 20\right.$, $46^{\prime}$ ' e $55^{\circ} 03,62^{\prime} \mathrm{W}$ ). Cerca de dois quilômetros à frente, foi observado um conjunto de arenitos médios a grossos, com níveis conglomeráticos $\left(19^{\circ} 20,15^{\prime} \mathrm{S}\right.$ e $55^{\circ}$ 04,66 $W$ ), que está sotoposto aos sedimentos finos definidos como pertencentes à Formação Vila Maria. A menos de dois quilômetros, em direção ao Pantanal, pode-se observar o contato desses arenitos com o embasamento. A espessura medida para esse conjunto, composto pelos arenitos e siltitos / arenitos finos, é de 40 metros.

Ainda na região de Rio Negro foram diagnosticados siltitos e folhelhos com intercalações de barras tempestíticas (Fig. 03B) $\left(19^{\circ} 28,50^{\prime} \mathrm{S} \mathrm{e}\right.$ 


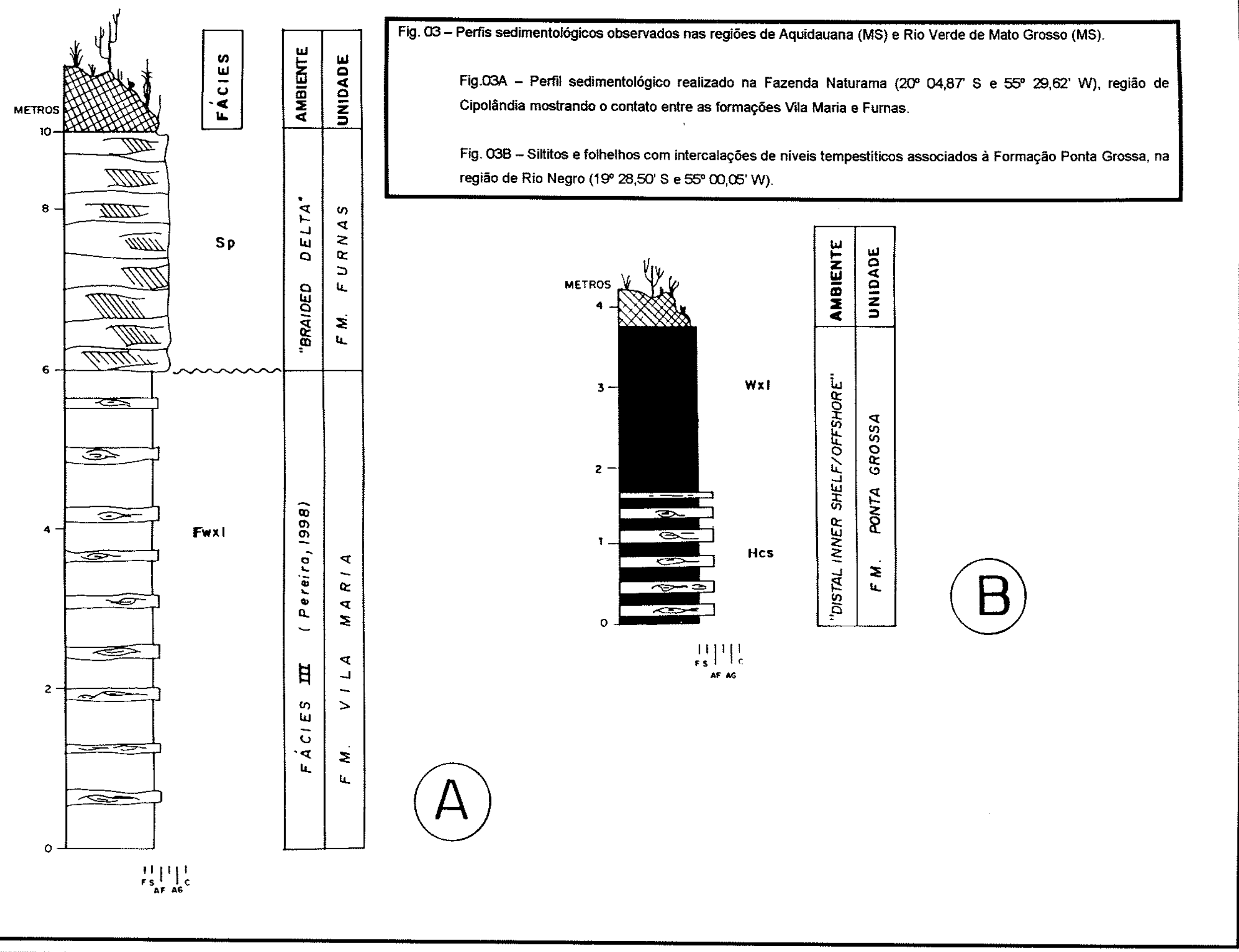


$5500,05^{\prime} \mathrm{W}$ ), que representam o registro do membro superior da Formação Ponta Grossa na área.

2.1.1.3 - Região de Rio Verde de Mato Grosso (MS) e Coxim (MS)

O trecho da Serra de Maracajú, entre as cidades de Rio Verde de Mato Grosso e Coxim, é marcado por um conjunto complexo de estruturas tectônicas, como bem visualizado no mapa geológico de Corrêa et al., (1979). Assim, o levantamento de seções geológicas regionais deve ter o cuidado em diagnosticar estas falhas no controle do registro geológico preservado. Neste trecho foram realizadas três seções geológicas denominadas de: Morro da Alegria, Serra de Maracajú e Sete Quedas.

Nesta região, no mapa de Corrêa et al. (1979), a área de afloramento é representada por uma extensa faixa de rochas associadas à Formação Furnas. Contudo, as várias seções geológicas levantadas na região demonstram a existência de diferentes litologias de difícil mapeamento regional.

A dificuldade do mapeamento deve-se, primeiramente, à pequena possibilidade de acesso às áreas escarpadas, onde poderiam estar preservadas as relações originais de contato; em segundo lugar, ao intemperismo dos sedimentos finos, siltitos e folhelhos, que impossibilita a obtenção de resultados palinológicos seguros e finalmente ao extenso processo de oxidação ao qual foram submetidos os sedimentos arenosos presentes na área.

A oxidação dos arenitos não pode ser utilizada como um elemento diagnóstico para a determinação da posição estratigráfica dos pacotes arenosos, uma vez que a oxidação ocorre de forma generalizada, como produto de uma frente de oxidação a partir dos sedimentos vermelhos da Formação Aquidauana. Este processo é bem identificado na região do sudoeste de Goiás, onde os 
arenitos associados ao Membro Médio da Formação Ponta Grossa possuem uma intensa coloração vermelha. Estes arenitos estão, normalmente, naquela área, em contato direto com os arenitos da Formação Aquidauana e sobrepostos aos folhelhos e siltitos do Membro Inferior da Formação Ponta Grossa. Estes sedimentos finos funcionam como um selo para uma frente de oxidação, estabelecida a partir da Formação Aquidauana. Assim, como pode ter ocorrido uma homogeneização da coloração, a mesma não deve ser utilizada para definir o posicionamento estratigráfico.

Na Região de Rio Verde de Mato Grosso e Coxim, a primeira seção (Morro da Alegria) foi realizada na estrada vicinal que parte do $\mathrm{Km} 699$ da rodovia BR - 163 e segue em direção a oeste até à sede da Fazenda Alegria. Nesta seção, a cerca de $5 \mathrm{~km}$ da BR - $163\left(18^{\circ} 44,184^{\prime}\right.$ ' S e $\left.54^{\circ} 51,72^{\prime} \mathrm{W}\right)$, observa-se um conjunto de afloramentos compostos por conglomerados suportado por matriz (litofácies $\mathrm{Gm}$ ) de coloração vermelha, onde são observados seixos e blocos de quartzo, quartzitos, fragmento de rochas e cristais de feldspato (Fig. 02D). Os seixos são angulosos a subarredondados e estão envoltos por uma matriz de granulometria areia grossa. Estes sedimentos ocorrem associados a um bloco baixo de falha, mapeado ao norte da cidade de Rio Verde de Mato Grosso (Projeto RADAMBRASIL, vol. 27; Del'Arco et al., 1982) de direção NW - SE. Esses sedimentos são aqui relatados pela primeira vez, sendo os mesmos associados à Formação Aquidauana. Nesta seção não foi possível observar as relações de contato entre esta unidade com a Formação Furnas, nem a relação de contato entre a seção sedimentar e o embasamento, representado pelo Granito Coxim. Contudo, na escarpa da Serra da Alegria ( $18^{\circ} 42,28^{\prime} S$ e $54^{\circ} 57,26^{\prime} \mathrm{W}$ ) pôde ser observado, próximo ao embasamento granítico, um pacote de cerca de 01 metro de espessura, composto por conglomerado suportado por clasto, que dão lugar a um conjunto de arenitos com granulometria variando de médio a grossa, intercalados por niveis centimétricos e decimétricos de conglomerado. Os arenitos que compõem a escarpa estão oxidados e são associados à Formação Furnas. 
Ainda nesta região, a segunda seção (Serra do Maracajú) foi realizada na estrada vicinal que parte do $\mathrm{Km} 699$ da rodovia $\mathrm{BR}$ - 163 e segue na direção sudoeste até a Fazenda Alvorada, junto ao Córrego Pindaivão, onde se pode cruzar a escarpa da Serra de Maracajú.

Miläni et al. (1995) descrevem, nesta mesma localidade, a existência de um conjunto pelítico arenoso avermelhado capeado pela Formação Furnas. Assine et al. (1998b), também relatam a presença de uma espessa seção associada aos sedimentos pré-Furnas com mais de 140 metros. Contudo, a seção apresentada por estes autores não é contínua.

O trabalho de campo realizado nesta seção demonstra a existência de três conjuntos sedimentares distintos. O primeiro é composto por corpos de conglomerado suportado por clasto, constituído por grãos de quartzo e feldspatos e seixos de quartzo, e com estratificação cruzada planar (Gp). Estes sedimentos são observados na forma de grandes blocos deslocados na base da Serra de Maracajú ( $18^{\circ} 44,18^{\prime} \mathrm{S}$ e $54^{\circ} 51,72^{\prime} \mathrm{W}$ ). O segundo conjunto sedimentar é formado por arenitos vermelhos, apresentando estratificação cruzada, intercalados por níveis centimétricos a decimétricos de conglomerados, apresentando-se sob a forma de corpos tabulares de grande continuidade lateral. Toda a área acessível da escarpa é formada por esta litologia ( $18^{\circ} 48,70^{\prime} \mathrm{S}$ e $54^{\circ} 58,74^{\prime} \mathrm{W}$ ). O terceiro conjunto é representado um pacote de siltito vermelho com intercalações de niveis arenosos e conglomeráticos. Neste siltito observa-se a presença de grãos tamanho areia dispersos na matriz fina. O mesmo é facilmente observado na fazenda Santa Terezinha (18 $57,26^{\prime} \mathrm{S}$ e $\left.54^{\circ} 57,26^{\prime} \mathrm{W}\right)$, situada a cerca de $4 \mathrm{~km}$ da escarpa da Serra de Maracajú.

Este último conjunto sedimentar vem sendo associado, na literatura recente, aos siltitos da Formação Vila Maria, em função do posicionamento estratigráfico e das características litológicas. Contudo, o posicionamento estratigráfico é duvidoso pois não se observa, diretamente, as relações de contato 
desse conjunto com os demais sedimentos descritos na seção. Por outro lado, esta litofácie é similar a outros sedimentos observados na região de Rio Negro $\left(19^{\circ} 40,00^{\prime} \mathrm{S}\right.$ e $54^{\circ} 59,19$ 'W) que estão associados à Formação Aquidauana.

Na seção da Serra de Maracajú não existem elementos seguros que possam levar "a uma definição correta do posicionamento estratigráfico dos sedimentos. A observação inédita de litofácies que são também descritas para a Formação Aquidauana, abre a possibilidade de se correlacionar parte dos sedimentos estudados a esta unidade.

A terceira seção (Sete Quedas) na região de Rio Verde de Mato Grosso e Coxim foi levantada no trecho final da rodovia Transpantaneira (BR-419), entre a cidade de Rio Verde de Mato Grosso (MS) e a descida da Serra de Maracajú. Nesta seção, como nas anteriores, existe uma grande dificuldade em se estabelecer as relações estratigráficas dos sedimentos estudados, uma vez que a seção foi levantada no domínio de um grande falhamento, o qual conhecide com o traçado da BR-419.

Nesta seção a cerca de $20 \mathrm{~km}$ do Parque das Sete Quedas, no município de Rio de Verde de Mato Grosso, observa-se uma pequena escarpa

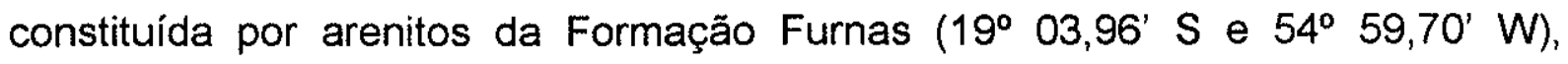
controlada por falha.

Continuando a seção, pode ser identificado um espesso conjunto sedimentar síltico-arenoso, bastante oxidado, ainda não relatado na literatura (19 $05,32^{\prime} \mathrm{S}$ e $\left.55^{\circ} 01,67^{\prime} \mathrm{W}\right)$. Estes sedimentos arranjam-se sob a forma de ciclos tempestíticos. A cerca de $1 \mathrm{~km}$ deste ponto (19 $05,91^{\prime} \mathrm{S}$ e $55^{\circ} 02,07^{\prime} \mathrm{W}$ ), junto a uma pequena queda d'água, registra-se o contato basal entre este conjunto sedimentar e uma espessa seção de arenitos e conglomerados. 
Em função da relaçào de contato por falha existente entre a escarpa isolada formada por arenitos da Formação Furnas e o conjunto síltico-arenoso e, também, pelas características sedimentológicas deste conjunto sedimentar, o mesmo é definido como pertencente à Formação Ponta Grossa. Assim, é possível definir a relação de contato basal da Formação Ponta Grossa com a Formação Furnas.

Na mesma estrada, $6 \mathrm{Km}$ após a queda d'água é possível identificar a relação de contato entre uma espessa seção arenosa de coloração avermelhada (cor de oxidação) com o embasamento, representado por filitos do Grupo Cuiabá $\left(19^{\circ} 07,70^{\prime} \mathrm{S}\right.$ e $55^{\circ} 03,68^{\prime} \mathrm{W}$ ). Este contato é observado na base da Serra de Maracajú. Ao longo da descida desta serra, ocorrem afloramentos com grande extensão lateral, compostos por corpos arenosos imbricados, arranjados sob a forma de geometrias lenticulares contínuas, cujo os conjuntos estão limitados por surperficies arquiteturais expressivas. Internamente, os arenitos apresentam estratificações cruzadas do tipo acanalada e planar (Fig. 04A).

Na seção ao longo da Serra não se observa a continuidade entre o conjunto arenoso marcado pela geometria lenticular com a seção arenosa sobre o embasamento. Contudo, não são notadas evidências para a definição de falhamentos no trecho da serra. Consideramos que este conjunto arenoso é representativo da Formação Furnas. Contudo, a existência de falhamentos mapeados entre a Serra de Maracajú e os afloramentos observados na estrada de acesso à Serra, não permitem postular uma continuidade estratigráfica entre a seção arenosa em contato com o embasamento e aquela em contato com a Formação de Ponta Grossa.

$\mathrm{Na}$ cidade de Rio Verde de Mato Grosso ocorrem inúmeros afloramentos de folhelhos e siltitos associados à Formação Ponta Grossa. Nas várias áreas de exploração de argila para cerâmica podem ser descritas espessas seções de folhelho (Fig. 04b-B), que são limitadas abruptamente por corpos 


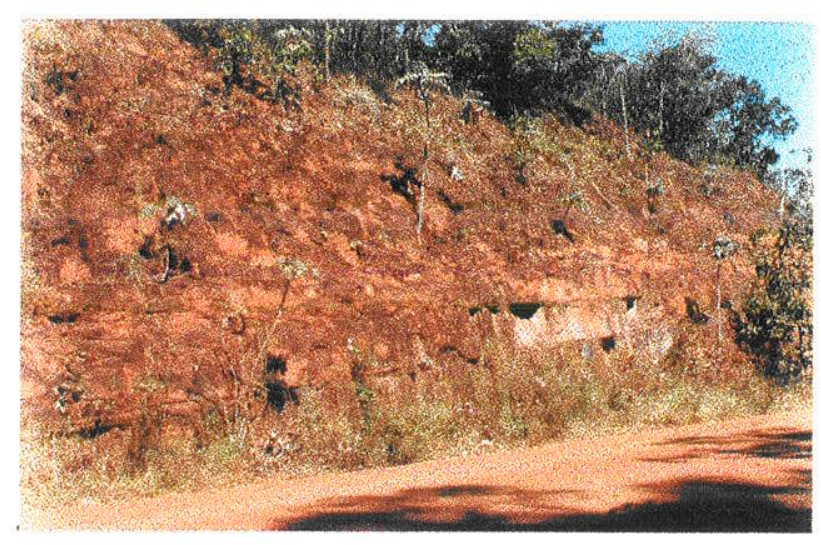

$4 \mathrm{~A}$

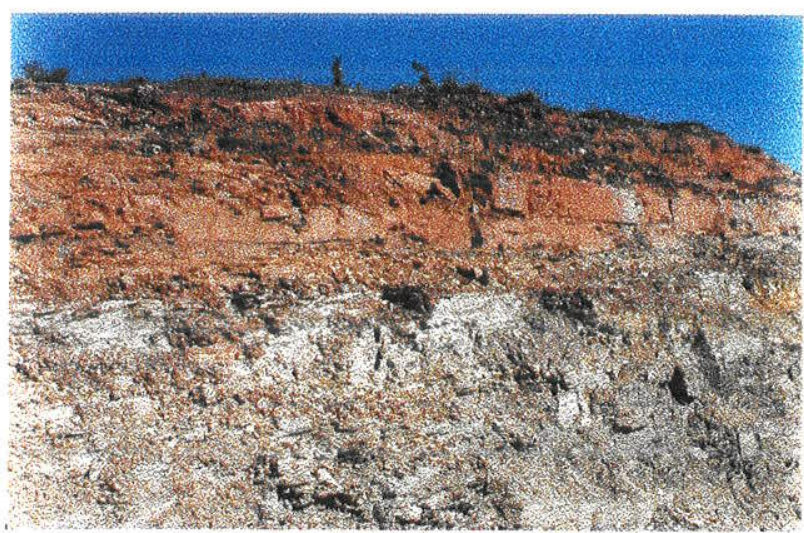

$4 \mathrm{C}$

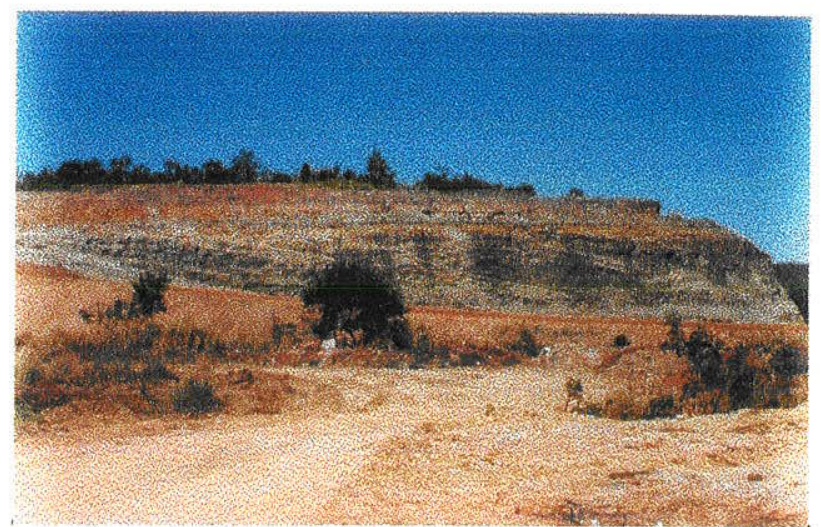

4B

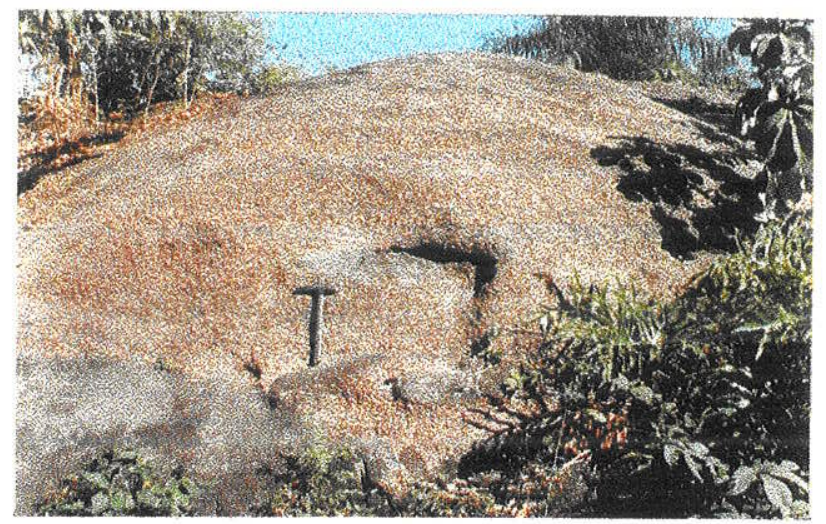

4D

Fig. 04a - Aspectos sedimentológicos observados nas regiões de Rio Negro (MS) e Rio Verde de Mato Grosso (MS).

A - Copos arenosos de grande extensão, com geometria lenticular, imbricados, apresentando estratificação cruzada planar, associados à Formação Furnas, na região de Rio Verde de Mato Grosso $\left(19^{\circ} 07,70^{\prime}\right.$ S e $55^{\circ}$ $03,68^{\prime} \mathrm{W}$ )

B - Espessa seção de folhelho praguiano, limitada por corpos arenosos tempestíticos. Barreiro Felix, Rio Verde de Mato Grosso $\left(18^{\circ} 55,57^{\prime}\right.$ 'S e $\left.54^{\circ} 50,41^{\prime} \mathrm{W}\right)$

C - Contato brusco, de caráter discordante, entre os ciclos tempestíticos e os folhelhos praguianos, observado no Barreiro Felix

D - Conglomerado oligomítico, quartzoso, suportado por clasto, com seixos achatados, depositados por ressedimentação, observado próximo a Coxim $\left(18^{\circ} 24,36^{\prime} \mathrm{S}\right.$ e $\left.54^{\circ} 53,14^{\prime} \mathrm{W}\right)$ 

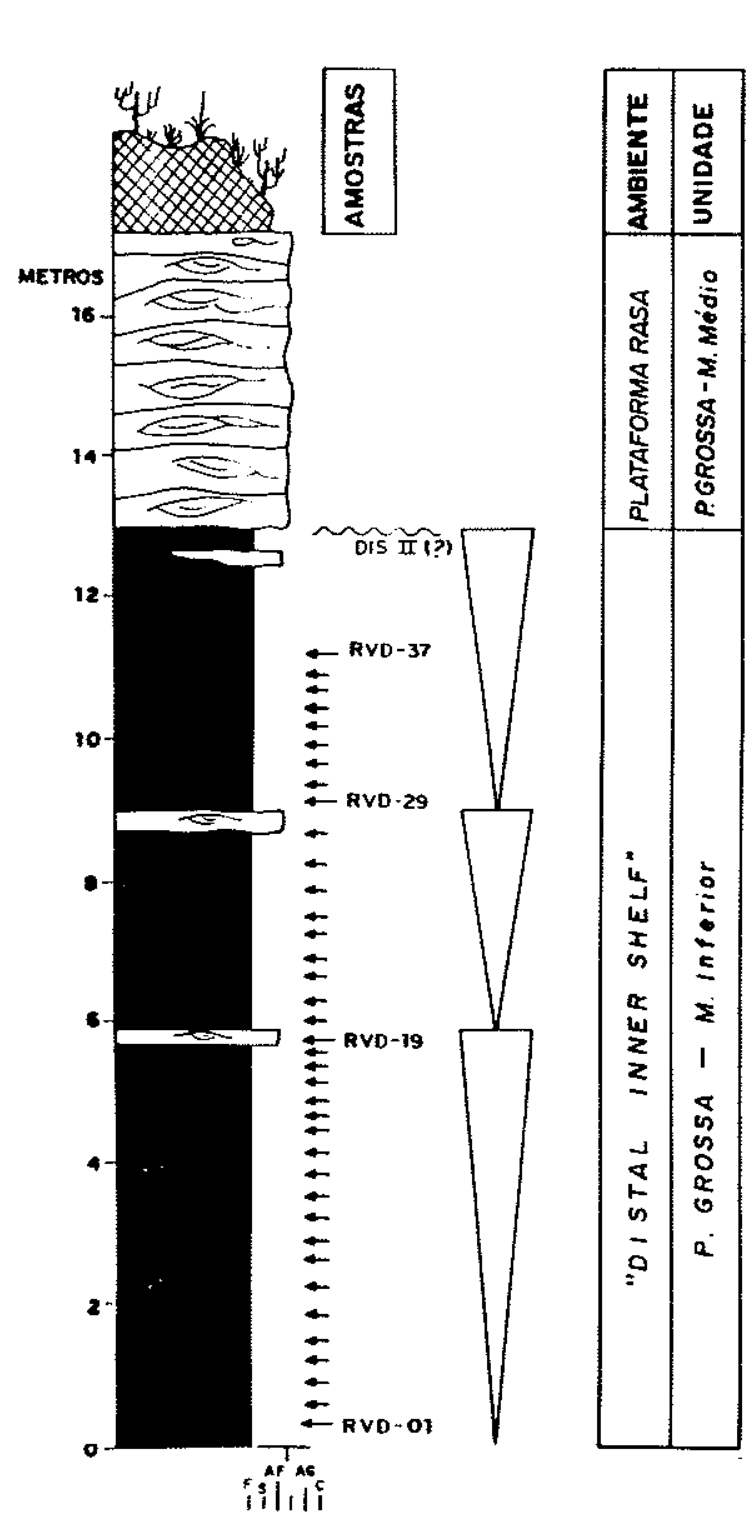

Fig. 04b - Perfis sedimentológicos observados nas regiöes de Rio Verde de Mato Grosso (MS) e Coxim (MS)

Fig.04A - Perfil estratigráfico de detalhe na seção de folhelho de idade Praguiana, mostrando o posicionamento das amostras coletadas para análise geoquimica e palinológica. Barreiro Felix, Rio Verde de Mato Grosso (18 $55,57^{\prime}$ ' S e $54^{\circ} 50,41^{\prime}(W)$.

Fig. O4B - Perfil estratigráfico de detalhe nas proximidades de Coxim (18 $24,36^{\prime} \mathrm{S}$ e $\left.54^{\circ} 53,14^{\prime} \mathrm{W}\right)$. demonstrando os conglomerados oligomíticos, quartzoso, suportado por clastos, com seixos achatados, depositados possivelmente por ressedimentação.
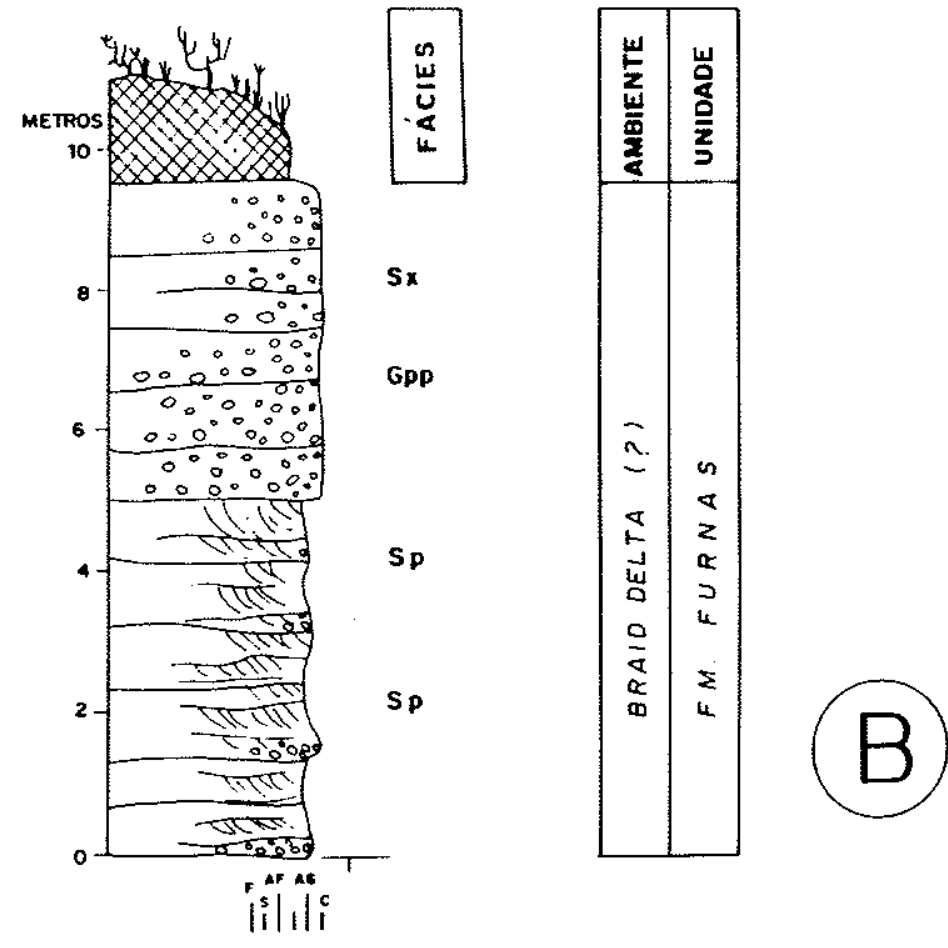
arenosos tempestísticos, como diagnosticado por Coimbra et al. (1995) (Fig. 04bC). Esses folhelhos datados do Eodevoniano (Praguiano) (Grahn et al., no prelo, 1999) representam a primeira superfície de afogamento de caráter regional presente na bacia.

Em toda a área aflorante observa-se, sobre os folhelhos, uma seção arenosa composta por pacotes tempestíticos arranjada sob a forma de ciclos de engrossamento para o topo, sendo a estratificação cruzada por onda (Hummocky) a feição sedimentar mais conspícua. Esses sedimentos são associados ao Membro Médio da Formação Ponta Grossa; os mesmos apresentam características sedimentológicas idênticas àquelas definidas para esta mesma unidade estratigráfica no sudoeste de Goiás por Pereira (1992) e para outras áreas da sub-bacia do Alto Garças por Pereira \& Bergamaschi (1996). Em situações específicas, como no Barreiro Felix em Rio Verde de Mato Grosso ( $18^{\circ}$ $55,57^{\prime} \mathrm{S}$ e $54^{\circ} 50,41^{\prime} \mathrm{W}$ ) pode ser observado um contato brusco, de caráter discordante, entre os arenitos e os folhelhos. Essa discordância materializa o hiato temporal definido para a seção devoniana em termos palinológicos, já relatados por Pereira \& Bergamaschi (1996), Pereira et al. (1998), Grahn (1998), Grahn (1999). O tempo envolvido neste hiato pode ser determinado em função dos resultados palinológicos apresentados em Carvalho et al. (1987), obtidos a partir dos folhelhos posicionados imediatamente acima dos arenitos tempestíticos. Esses autores indicam uma idade Eifeliana para a amostra analisada. Assim, este hiato poderia conter ao menos todo o intervalo emsiano.

No município de Coxim (MS) foi realizada uma seção geológica ao longo da estrada vicinal que liga esta cidade à região pantaneira. Da mesma forma que nas seções anteriores apresentadas, o empilhamento estratigráfico não é contínuo pois a seção é cortada por falhas normais que controlam o relevo escarpado. Nesta seção foram levantados dois perfis estratigráficos: No primeiro, em uma pequena escarpa $\left(18^{\circ} 28,62^{\prime} \mathrm{S}\right.$ e $\left.54^{\circ} 45,95^{\prime} \mathrm{W}\right)$, pode ser observada uma sucessão de corpos areníticos e conglomeráticos, de cerca de 10 metros. A partir 
do nivel da estrada, observam-se 5 metros de um conjunto de corpos de arenitos grosseiros, com geometria planar e estratificação cruzada planar. Este conjunto é limitado no topo por sucessivos pacotes de um conglomerado oligomítico, quartzoso, suportado por clastos, com seixos achatados. Em blocos associados ao recuo da encosta, esta superfície é marcada por feições de ravinamento. Os corpos conglomeráticos apresentam, por vezes, clastos de arenitos grosseiros envolvidos na matriz, os quais estão depositados acima da superfície de ravinamento. Tais características demonstram evidências de ressedimentação (Fig. 04a-D e Fig. 04b-B). Aparentemente, Assine (1996) associa estes conglomerados à Formação lapó. As características sedimentológicas observadas direcionam a interpretação deste perfil para a identificação de um limite intraformacional, marcado pela mudança da dinâmica dos processos deposicionais, inicialmente de caráter trativo e posteriormente de caráter gravitacional, definindo uma superfície de descontinuidade no contexto de um limite de seqüência de terceira ordem.

Ainda nesta seção um segundo perfil sedimentológico pode ser observado $\left(18^{\circ} 24,36^{\prime} \mathrm{S}\right.$ e $\left.54^{\circ} 53,14^{\prime} \mathrm{W}\right)$. Neste se identifica a relação de contato entre o conjunto arenoso e o embasamento, composto por filitos do Grupo Cuiabá. O conjunto arenoso apresenta as mesmas características sedimentológicas da seção anterior. Sobre o embasamento são depositados arenitos grossos a conglomeráticos, com estratificação cruzada planar $(\mathrm{Sp})$ e estão presentes seixos achatados.

Não é possivel estabelecer uma relação direta entre os dois perfis. 0 segundo perfil é observado, no topo da escarpa, em um bloco alto e o primeiro está um pouco acima da cota topográfica do Rio Coxim. Se admitirmos que a descontinuidade observada no primeiro perfil seja um limite de terceira ordem, representando somente uma variação na dinâmica de sedimentação, toda a seção analisada estaria associada à Formação Furnas. Esta dinâmica seria inicialmente marcada por fluxos trativos, responsáveis pela deposição de arenitos com 
estratificaçăo cruzada e posteriormente definida pela ação de fluxos gravitacionais responsáveis pela deposição dos conglomerados $\mathrm{Na}$ hipótese desta descontinuidade ter uma maior magnitude, estariamos então diagnosticando um resquício de uma sedimentação pré-Furnas preservada.

A'o longo da BR-163, nas proximidades de Coxim (MS) são observadas excelentes exposições de corpos arenosos associados à Formação Furnas. Neste intervalo estratigráfico há um predomínio de fácies sedimentares associadas a processos deposicionais relacionadas a ambientes de plataforma rasa dominada por ondas e com influência de ação de marés (Pereira et al. 1995a).

Na região de Coxim não é observada a relação de contato entre as formações Furnas e Ponta Grossa. Contudo, a parte basal da Formação Ponta Grossa pôde ser diagnosticada a partir de excelentes exposições, como na Cachoeira das Palmeiras, no leito do Rio Taquari ( $18^{\circ} 21,70^{\prime} \mathrm{S}$ e $54^{\circ} 36,72^{\prime} \mathrm{W}$ ).

\subsubsection{4 - Região de Pedro Gomes (MS) e Sonora (MS)}

No extremo norte do estado de Mato Grosso do Sul foram realizadas duas outras seções geológicas nos municípios de Pedro Gomes e Sonora. Na região de Pedro Gomes é possível identificar toda a seção devoniana da bacia. Pela primeira vez foi caracterizado o membro Médio da Formação Ponta Grossa nesta região, corroborando o modelo de distribuição regional para estas rochas (Pereira, 1992; Pereira \& Bergamaschi, 1996 e Pereira et al., 1998).

Nesta localidade os sedimentos associados ao Membro Médio apresentam as mesmas características sedimentológicas observadas na região de Rio Verde de Mato Grosso, destacando-se os ciclos tempestíticos arranjados em conjuntos marcados pelo engrossamento para o topo. Nesta região, em diversos 
cortes de estrada, estas características podem ser diagnosticadas $\left(18^{\circ} 10,71^{\prime} \mathrm{S}\right.$ e $54^{\circ} 38,23^{\prime} \mathrm{W}$ ).

Sobrepondo-se a estes sedimentos ocorre um espesso pacote sedimentar composto por folhelhos e siltitos, litoestratigraficamente denominados de Membro Süperior da Formação Ponta Grossa, que representam a segunda inundação de caráter regional na bacia. As fácies sedimentares observadas $\mathrm{Fml} \mathrm{e}$ Fwxl, nas diversas pedreiras de extração de argila ( $18^{\circ} 07,53^{\prime \prime} \mathrm{S}$ e $54^{\circ} 32,66^{\prime} \mathrm{W}$ ), diagnosticam as condições marinhas de costa afora (offshore) para a deposição desses sedimentos.

No município de Sonora é possível realizar uma seção geológica cruzando a Serra do Pantanal. A partir da cidade, através da estrada vicinal da Usina de Cana que cruza a Fazenda Horizonte, atinge-se a descida Serra e a planície do Pantanal $\left(17^{\circ} 38,57 \mathrm{~S}\right.$ e $\left.54^{\circ} 56,51 \mathrm{~W}\right)$.

Nesta seção näo se observa diretamente o contato entre o embasamento e o conjunto sedimentar. No entanto, na quebra da escarpa que sustenta o planalto, ocupado por plantações da Fazenda Horizonte, observa-se extensos afloramentos compostos por conglomerados e arenitos grossos, portadores de fácies Gt e St, de coloração avermelhada, alinhados na direção NE$\mathrm{SW}$. Esses sedimentos apresentam aspectos sedimentológicos similares àqueles descritos na região da Serra da Alegria. Desta forma, os mesmos são associados à Formação Aquidauana. Registra-se assim, pela primeira vez nesta região, esta formação marcando a quebra da escarpa da Serra do Pantanal. A presença de sedimentos associados à Formação Aquidauana pode ainda ser observada na altura do quilômetro 840 da BR-163.

Continuando a descida da Serra, observa-se, aparentemente em contato por falha, a presença de arenitos brancos, de granulometria fina à média, caracterizados pela presença da fácies $\mathrm{Sp}$. Esses sedimentos são associados à 
Formação Furnas. Assim, de modo especulativo, os sistemas de falhas do Rio Correntes e da Serra Solteira controlaram a evolução deste segmento da Serra do Pantanal, gerando um deslocamento relativo dos sedimentos associados à Formação Aquidauana.

\subsection{2 - Dados de campo obtidos no estado de Mato Grosso}

No estado de Mato Grosso foram levantados perfis estratigráficos de detalhe e seções geológicas nos seguintes municípios: Itiquira, Rondonópolis, São Lourenço de Fátima, Chapada dos Guimarães, Dom Aquino, Paranatinga, General Carneiro, Barra dos Garças, Vale dos Sonhos, Nova Xavantina, Canaranã, Araguainha, Pedra Branca e Torixoreú.

\subsubsection{1 - Região de Itiquira (MT)}

As seções geológicas levantadas na região de Itiquira foram realizadas em duas estradas vicinais, que cortam o trecho sul da Serra de São Jerônimo, e partem da BR-163, na altura do posto da Policia Rodoviária do

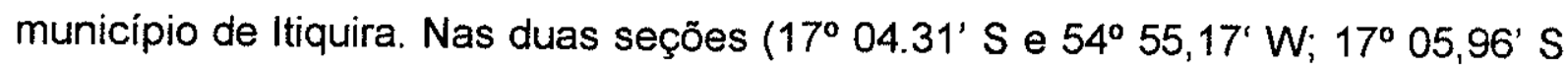
e $54^{\circ} 54,58^{\prime}$ W) é observado o contato entre o conjunto sedimentar e o embasamento, representado por filitos do Grupo Cuiabá. Os sedimentos observados são formados por arenitos brancos, médios a grossos, com geometria lenticular, às vezes sigmoidal e portadores de estratificação cruzada planar (Sp). Esses sedimentos são associados à Formação Furnas. De modo diferente ao mapeado na região de Sonora (MS), não se constata a presença da Formação Aquidauana neste trecho do conjunto de serras denominado Serra do Pantanal. Este fato pode ser um elemento adicional na identificação de um controle tectônico exercido pelo Lineamento Transbrasiliano na definição do limite oeste da Bacia do Paraná, como já proposto por Schobbenhaus Filho (1975). 
2.1.2.2 - Região de São Lourenço de Fátima e Rondonópolis (MT)

A região de São Lourenço de Fátima, no que se refere à caracterização "dos sedimentos pré-devonianos da Bacia do Paraná, foi apresentada pela primeira vez na literatura, por meio da identificação de sedimentos silurianos equivalentes à Formação Vila Maria, por Pereira et al. (1995b) e pela caracterização do icnogênero Arthrophycus, em sedimentos associados a esta formação por Fernandes et al. (1994).

O trecho noroeste da Serra de São Jerônimo é cortado por grandes falhamentos normais (Falha do São Lourenço, Falha do Coroados e Falha Água Quente), com direção NE-SW, associadas ao limite norte do Lineamento Transbrasiliano. Ocorrem ainda falhamentos normais, de menor magnitude, com direção NW-SE.

Nesta região existem quatro localidades nas quais podem ser observadas, de forma parcial, as relações estratigráficas entre os conjuntos sedimentares pré-devoniano e devoniano. Três localidades estão situadas ao longo de uma estrada vicinal que margeia o rio São Lourenço, a partir da vila de São Lourenço de Fátima até a localidade de "Acerta Conta". A quarta localidade está situada a oeste da referida vila junto à Serra de São Jerônimo.

$\mathrm{Na}$ primeira, mais ao sul, próximo ao local denominado "Acerta Conta", observa-se diretamente na escarpa, o contato entre as formações Furnas e Vila Maria. Neste local $\left(16^{\circ} 27,27^{\prime} \mathrm{S}\right.$ e $54^{\circ} 58,87^{\prime} \mathrm{W}$ ) pode ser visualizada (Fig. 05A) uma superfície erosiva nítida que coloca em contato corpos arenosos tabulares compostos por arenitos finos a médios, com Hummocky cross stratification (fácies Shcs) pertencentes à Formação Vila Maria e arenitos grossos da Formação Furnas. Esses últimos apresentam geometria lenticular e são 


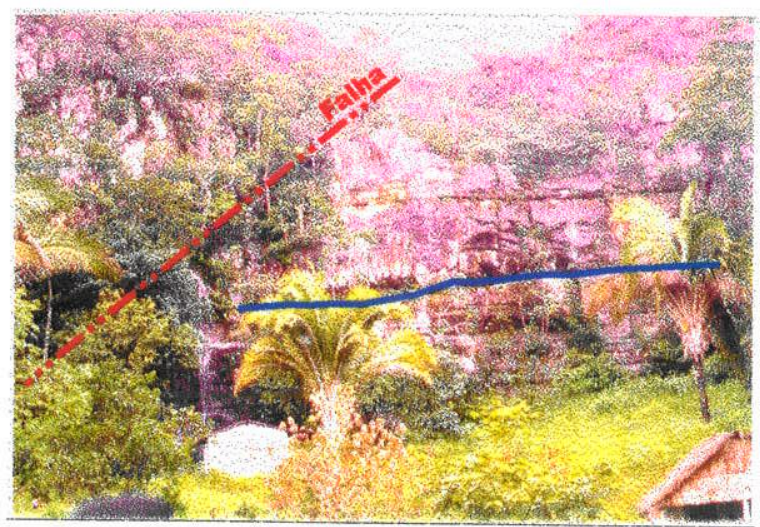

$5 \mathrm{~A}$

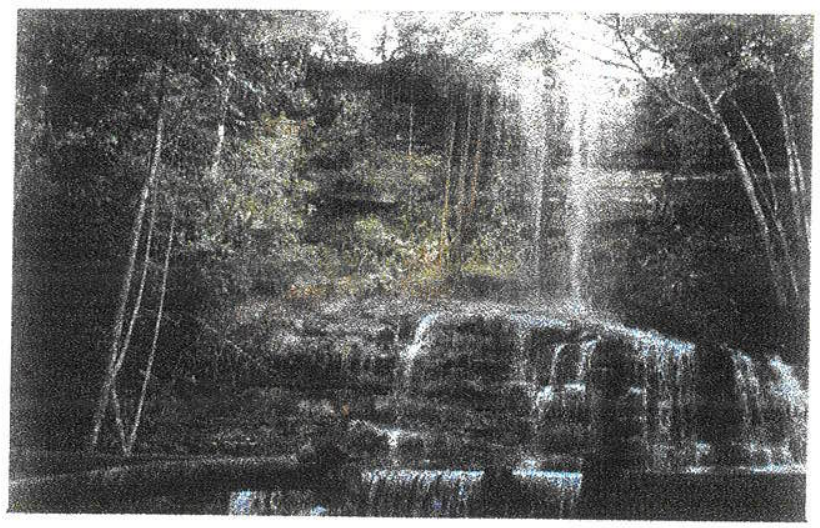

$5 \mathrm{C}$

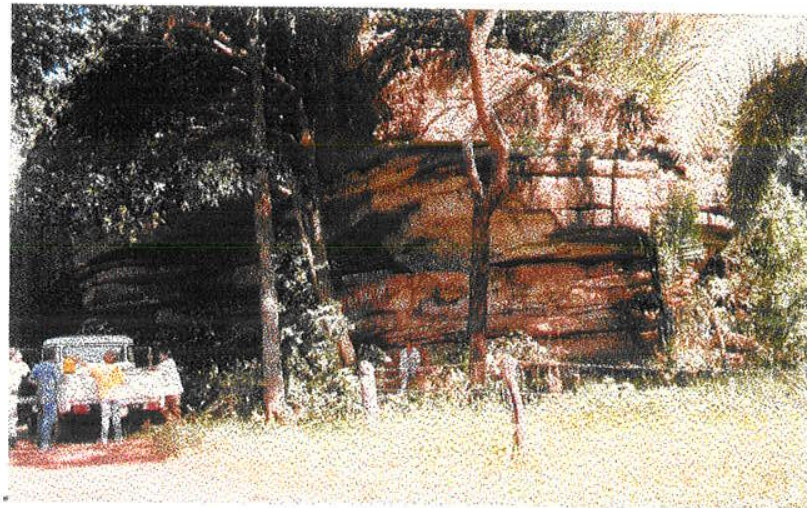

$5 \mathrm{~B}$

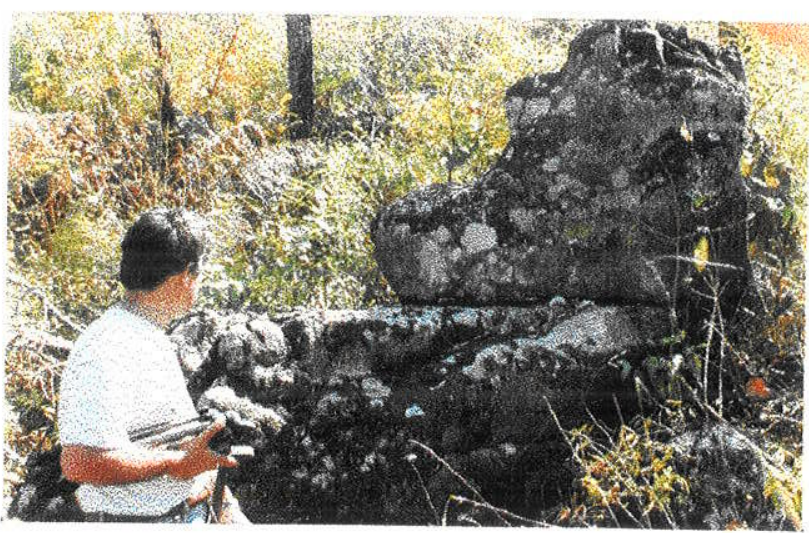

$5 \mathrm{D}$

Fig. 05 - Aspectos sedimentológicos observados na região de São Lourenço de Fátima (MT).

A - Contato entre as formações Vila Maria e Furnas, na localidade de "Acerta Conta", próximo a São Lourenço de Fátima $\left(16^{\circ} 27,27^{\prime} \mathrm{S}\right.$ e $\left.54^{\circ} 58,87^{\prime} \mathrm{W}\right)$

B - Vista de detalhe dos sedimentos associados à Formação Vila Maria, na localidade de "Acerta Conta"

C - Vista geral dos sedimentos da Formação Vila Maria na Cachoeira do Bispo, próximo a São Lourenço de Fátima $\left(16^{\circ} 19,76^{\prime} S\right.$ e $\left.54^{\circ} 56,78^{\prime} \mathrm{W}\right)$

D - Detalhe dos arenitos finos, bioturbados, que estão intercalados em siltitos laminados, associados à Formação Vila Maria. Observados na Fazenda Sol Poente $\left(16^{\circ} 26,66^{\prime}\right.$ 'S e $\left.55^{\circ} 18,72 ' \mathrm{~W}\right)$ 
constituídos por arenitos brancos, de granulometria grossa, com seixos. Estratificação cruzada planar e acanalada (fácies $\mathrm{Sp}$ e St) são, normalmente, observadas. Neste afloramento, como em situações similares no sudoeste de Goiás (Pereira, 1998), o limite entre as duas unidades é caracterizado pelo contato entre fácies de plataforma rasa dominadas por onda do topo da Formação Vila Maria (Fig. 05B) e as fácies continentais de planície aluvial.

A segunda localidade está situada junto à escarpa da Serra dos Coroados, a cerca de $2 \mathrm{~km}$ do "Acerta Contas". Neste local, a seção descrita por Pereira et al. (1995b) demonstra a presença de intercalações de siltitos e folhelhos com arenitos portadores de estratificação cruzada por onda, em um arranjo granocrescente ascendente, pertencentes à Formação Vila Maria, em contato com a Formação Furnas.

Estas duas localidades situam-se na margem do Rio São Lourenço de Fátima, ao sul da Falha dos Coroados. Ao norte desta falha, Assine (1996), na localidade denominada Cachoeira do Bispo (16 $19,76^{\prime} \mathrm{S}$ e $54^{\circ} 56,78^{\prime} \mathrm{W}$ ), identifica a existência de um contato discordante entre as Formações Vila Maria e Alto Garças. A primeira constituída por sedimentos finos (siltitos e folhelhos) e a segunda representada por um espesso pacote de arenitos estratificados.

Na Cachoeira do Bispo pode ser observada uma nítida superfície de contato entre a base de um conjunto faciológico composto por intercalações de lentes de arenito fino, centimétricas, em siltito com laminação cruzada por onda, associados à Formação Vila Maria e um conjunto arenoso, de granulometria média, branco, maciço a laminado, com geometria lenticular (Fig. 05C). Esse conjunto arenoso foi denominado por Assine (1996) como pertencente à Formação Alto Garças. Nesta cachoeira não se observa a relação de contato entre este conjunto arenoso e o embasamento. 
A oeste da Vila de São Lourenço de Fátima, na estrada vicinal para a fazenda Sol Poente, na altura da Serra de São Jerônimo (16 $26,66^{\prime} S$ e $55^{\circ} 18,72^{\prime}$ W), ao norte da Falha Água Quente, foi levantada uma seção sedimentar (Fig. 06A), com cerca de 30 metros de espessura, onde pôde ser observada a intercalação de arenitos finos laminados e freqüentemente bioturbados em siltitos com laminação cruzada por onda. Para a base da seção passam a predominar os pacotes arenosos laminados. Assim, nesta localidade existe uma interdigitação entre as fácies mais finas da Formação Vila Maria e os arenitos sotopostos (Fig. 05D). Nesta seção, no entanto, não é observada a relação deste conjunto sedimentar com o embasamento. Contudo, próximo à seção da Fazenda Sol Poente, junto à Falha Água Quente (16 $27,26^{\prime}$ ' S e $55^{\circ} 19,76^{\prime} W$ ), foi descrita uma seção sedimentar (Fig. 06B), com cerca de 40 metros de espessura, onde se observa o contato entre o embasamento, representado pelo Grupo Cuiabá, e um conjunto arenoso formado por conglomerados e arenitos grossos, de coloração branca, apresentando estratificação cruzada acanalada (St) e planar (Sp). No entanto, não foi possivel estabelecer a relação entre os sedimentos que ocorrem imediatamente acima do embasamento com aqueles sotopostos à Formação Vila Maria.

As características sedimentológicas apresentadas por este pacote são extremamente similares àquelas definidas para a Formação Furnas. Se considerarmos a hipótese de associarmos estes sedimentos à Formação Furnas, estaríamos definindo uma importante mobilização no tempo pré-Furnas uma vez que, em áreas relativamente próximas, teríamos a ausência de toda a sedimentação siluriana. Esta situação abriria a possibilidade de considerarmos os falhamentos e lineamentos associados ao lineamento transbrasiliano como ativos durante esta mobilização.

Por outro lado, poderíamos também correlacionar o conjunto arenoso sobreposto ao embasamento à Formação Alto Garças, descrita na região de Chapada dos Guimarães por Borghi \& Moreira (1998), embora as características 

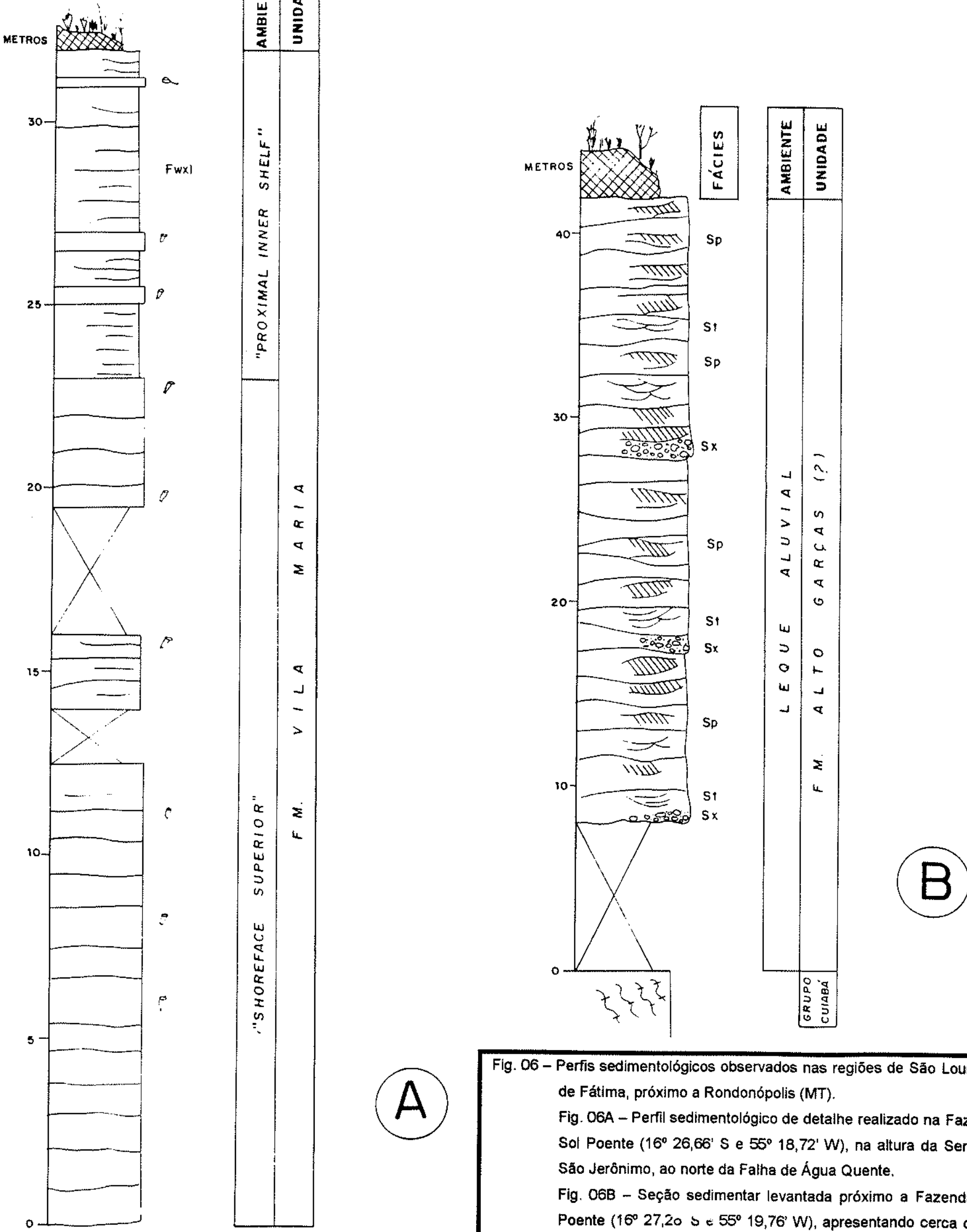

Fig. 06 - Perfis sedimentológicos observados nas regiōes de Sảo Lourenço de Fátima, próximo a Rondonópolis (MT).

Fig. O6A - Perfil sedimentológico de detalhe realizado na Fazenda Sol Poente $\left(16^{\circ} 26,66^{\prime} S\right.$ e $\left.55^{\circ} 18,72^{\prime} W\right)$, na altura da Serra de São Jerônimo, ao norte da Falha de Água Quente.

Fig. 06B - Seção sedimentar levantada próximo a Fazenda Sol Poente $\left(16^{\circ} 27,20\right.$ s e $55^{\circ} 19,76^{\prime} \mathrm{W}$ ), apresentando cerca de 40 metros de um conju, iu arenoso formado por conglomerados e arenitos, provavelmente associados à Formaçăo Alto Garças 
sedimentológicas apresentadas por estes autores sejam diferentes. Neste caso, estaríamos identificando dois conjuntos arenosos sotoposto à Formação Vila Maria. O primeiro, uma seção arenosa intercalada aos sedimentos finos da Formação Vila Maria e o segundo, uma outra seção arenosa, que inicia-se sobre o embasamento, "mas com limite superior não definido. Nesta concepção, na localidade definida como Cachoeira do Bispo, os arenitos observados abaixo das fácies de sedimentos finos da Formação Vila Maria devem pertencer ao pacote siluriano. Tal associação é também admitida por Borghi et al. (1999).

\subsubsection{3 - Região da Chapada dos Guimarães (MT)}

A região da Chapada dos Guimarães vem sendo estudada detahadamente, nos últimos anos, pelo Grupo de Pesquisa em Estratigrafia da UFRJ. Os resultados obtidos por estes pesquisadores foram sintetizados, recentemente por Borghi \& Moreira (1998). Estes autores advogam a existência de uma ampla área expositiva de rochas associadas ao Grupo Rio Ivaí (senso, Assine et al., 1994), na região oriental da Chapada dos Guimarães.

A descrição de rochas pré-devonianas na região de Chapada dos Guimarães foi originalmente proposta por Oliveira \& Muhlmann (1965). Esses autores diagnosticaram uma seção sedimentar residual, restrita aos escarpamentos localizados ao norte da cidade de São Vicente (MT). Nesta região os autores relatam a existência de dois conjuntos sedimentares sotopostos aos conglomerados basais da Formação Furnas. O primeiro seria composto por arenitos marrons a vermelho-arroxeados, médios a grosseiros, regularmente selecionados, pouco argilosos e ferruginosos, friáveis, com grãos subangulares a subarredondados, estratificação paralela espessa, intercalados por leitos de conglomerados com matriz arenítica e seixos arredondados (até $10 \mathrm{~cm}$ ) de quartzo e meta-arenitos com veios de quartzo. O segundo, sobreposto ao anterior, 
seria composto por arenito marrom arroxeado, fino a médio, muito argiloso, mal classificado, muito ferruginoso, micáceo, pouco friável, com estratificação espessa, plano-paralela.

Na mesma área, mais precisamente na serra do Ranchão, Almeida (1954), embora" associando todo o conjunto sedimentar por ele estudado à Formação Furnas, relata a existência de uma quebra estratigráfica a cerca de 75 metros da base do conjunto sedimentar, marcada por um pacote conglomerático com 4 metros de espessura com características sedimentares semelhantes àquelas observadas na base do conjunto sedimentar. Abaixo dessa quebra, o autor descreve 24 metros iniciais de arenitos conglomeráticos, com grande riqueza de quartzo leitoso e estratificação cruzada. $O$ restante desses 75 metros compõese de arenitos brancos, grosseiros, com raros seixos esparsos, friáveis. Dez metros acima da quebra assinalada, Almeida (1954) descreve a presença de camadas de folhelhos micáceos.

De certa forma a descrição apresentada por Oliveira e Muhlman (1965) corrobora o relato de Almeida (1954) para a região ao norte de São Vicente (MT). Da mesma forma, Borghi \& Moreira (1998) confirmam a existência de um conjunto sedimentar pré-devoniano no morro do Ranchão, um morro-testemunho, no município de Santo Antônio do Leverger (MT), ao norte de São Vicente (MT), localidade inicialmente analisada por Almeida (1954).

Nesta localidade, Borghi \& Moreira (1998) apresentam um perfil completo, com cerca de 130 metros de espessura, envolvendo as Formações Alto Garças e Vila Maria. A Formação Alto Garças, segundo os autores, na área estudada, é representada na base por uma fácies de conglomerado maciço, e para o topo por fácies de arenito maciço, arenito com laminação plano-paralela, arenito com laminação cruzada por onda e arenitos com Skolithos linearis. O contato entre a Formação Alto Garças e a Formação Vila Maria é definido pelos autores, na área, como discordante. 
A Formação Vila Maria, com exceção das fácies conglomeráticas basais, apresenta as mesmas características sedimentológicas observadas em várias outras localidades onde estes sedimentos afloram. Fácies conglomeráticas na base da seção Vila Maria, intercaladas a diamictitos são descritas por Rodrigues et al." (1995) no domínio da Serra Azul e do Taquaral, na região de Barra dos Garças (MT). Contudo, um aspecto peculiar para esta região é o posicionamento estratigráfico dos diamictitos em uma posição intermediária na seção estratigráfica, como demonstrado por Borghi \& Moreira (1998), de modo diferente ao normalmente observado na borda nordeste da Bacia, onde as fácies de diamictito ocorrem normalmente na base da seção siluriana (Pereira, 1998).

Quando comparamos a porção oriental da Chapada dos Guimarães com a região localizada a sudoeste do vilarejo de São Lourenço de Fátima, em relação aos sedimentos pré-devonianos, podemos observar que na região de São Lourenço de Fátima ocorre um espessamento do pacote arenoso sotaposto aos sedimentos mais finos (folhelhos e siltitos) da Formação Vila Maria, o que não é observado na região da Chapada dos Guimarães.

Com relação à Formação Alto Garças, os pacotes arenosos que poderiam ser correlacionados a esta unidade na região de São Lourenço de Fátima não apresentam as mesmas características faciológicas descritas para esta formação, por Borghi \& Moreira (1998), na Chapada dos Guimarães. No pacote de areia associado à Formação Alto Garças, não foram diagnosticadas as fácies de arenitos mais finos com estruturas plano-paralela, cruzada por onda e de arenitos com Skolithos linearis. Em verdade, estas fácies, na região de São Lourenço de Fátima, são mais comum aos arenitos intercalados aos sedimentos mais finos da Formação Vila Maria.

A distribuição dos sedimentos pré-devonianos na região da Chapada dos Guimarães ocorre de forma descontínua. A espessura da seção Alto Garças, 
segundo os dados de Borghi \& Moreira (1998), está em torno de 40 metros. Para os mesmos autores, a Formação Vila Maria possui uma espessura média de 20 metros, existindo porém um espessamento anormal da mesma na região do morro do Ranchão, onde são descritos cerca de 80 metros desta unidade. Porém, no limite ocidental da Chapada dos Guimarães, na área do Parque Nacional, a seção devoniana está depositada diretamente sobre o embasamento. Existem várias localidades onde esta situação pode ser mapeada, tais como: Cachoeira da Salgadeira, Morro de São Jerônimo e nas Cachoeiras Degrau, Andorinhas e Sete Quedas. Neste último grupo de cachoeiras a presença da seção devoniana pode ser confirmada em função da ocorrência de plantas vasculares em sedimentos que jazem a cerca de 15 metros do embasamento e que são definidos como de idade eodevoniana (Schubert \& Borghi, 1991). Na área das cachoeiras Degrau e Andorinha é possível estabelecer uma seção estratigráfica contínua a partir do embasamento até a primeira superfície de inundação eodevoniana, com espessura total de 27 metros (Fig. 07). Ao longo desta seção são observados dois níveis de ocorrência de restos de plantas vasculares primitivas, o primeiro a 15 metros do embasamento e o segundo a 21 metros. Estes restos vegetais são comparáveis aos descritos por Schubert \& Borghi (1991) na mesma região e são interpretados preliminarmente como pertencentes ao gênero Cooksonia. Por correlação com o material analisado por Gerrienne et al. (1998), a idade do material observado é provavelmente Eodevoniana, mais precisamente, Lochoviana/Praguiana.

Dessa forma, comparando a distribuição da espessura da seção prédevoniana entre a borda ocidental da Chapada dos Guimarães e o Morro do Ranchão, teríamos uma expressiva variação de espessura para a seção prédevoniana de cerca de 130 metros em pouco menos de $50 \mathrm{~km}$. Deve ser ressaltado que o conjunto sedimentar observado no Morro do Ranchão está preservado em um bloco baixo de falha, em um sistema de falhas normais escalonadas de direção NE-SW, pertencentes ao Lineamento Transbrasiliano, que limita, a noroeste, a ocorrência do Granito São Vicente. A relação entre rochas 


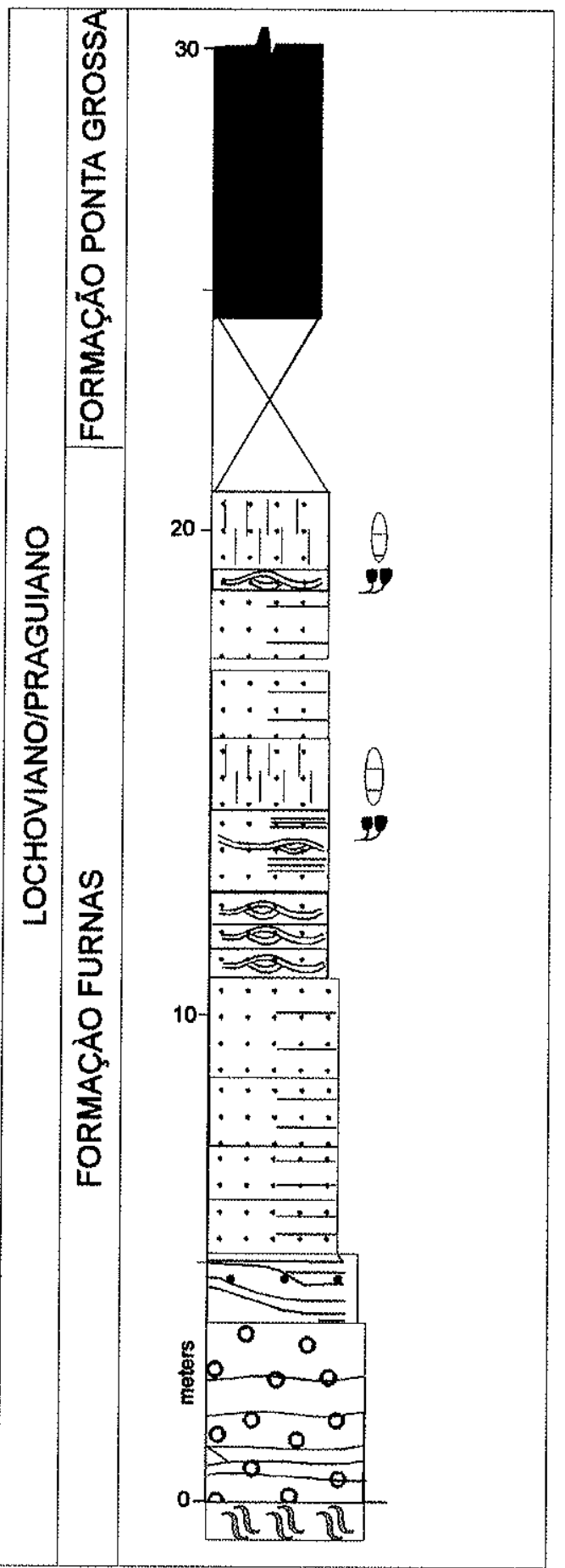

Fig. 07 - Perfil sedimentologico na regiăo da Cachoeira Degrau e Andorinha, Chapada dos Guimaraes (MT)

\begin{tabular}{|c|c|c|c|c|c|c|}
\hline$Q$ & 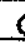 & 2 & g & Arenito grosso & 3 & Restos Vegetais \\
\hline & & & & Arenito médio & $A$ & Icnofossit Skolithas linearis \\
\hline$\cdot$ & - & + & + & Arentto fino & 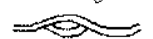 & Estr. cruz. Hummocky \\
\hline
\end{tabular}


íneas ácidas e o Lineamento Transbrasiliano, pode ainda ser observada a sudoeste de São Lourenço de Fátima ( $16^{\circ} 27,07^{\prime}$ S e $55^{\circ} 19,02^{\prime} \mathrm{W}$ ) onde foram identificados diques, de idade não definida, de composição riolítica, preenchendo falhas de direção NE-SW deste lineamento.

\subsubsection{4 - Região de Dom Aquino (MT)}

$\mathrm{Na}$ região de Dom Aquino (MT) são caracterizados sedimentos de idade Neo-Devoniana, associados ao Membro Superior da Formação Ponta Grossa. A presença desses sedimentos pode ser observada ao longo da Rodovia (MT-130) que liga a cidade de Dom Aquino a Campo Verde. Nesta rodovia existem vários cortes de estrada que apresentam um espesso conjunto sedimentar composto por siltitos e folhelhos negros.

A cerca de $20 \mathrm{~km}$ da cidade de Dom Aquino foi levantada uma seção geológica detalhada (Fig. 08). Esta seção, com cerca de 60 metros, é caracterizada pela presença de ciclos de granulocrescência ascendente, limitados por superfícies de inundação. Estes ciclos são compostos, na base, por folhelhos negros e siltitos, que gradam para siltitos e arenitos muito finos portadores de estratificação do tipo wavy/Linsen e estratificação cruzada por ondas. Os mesmos definem um nítido conjunto de parasseqüências de caráter progradacional, representativo da transição Givetiano - Frasniano.

A idade desta seção foi inicialmente obtida por Oliveira et al. (1995), a partir de uma coleta preliminar no afloramento. Uma amostragem mais adensada foi realizada neste mesmo afloramento visando a análise geoquímica, bem como o estudo palinológico sistemático com base em quitinozoas. Os resultados obtidos por Grahn (1998) confirmam a idade anteriormente obtida. Com relação aos dados geoquímicos, os mesmos demonstram claramente a ciclicidade 


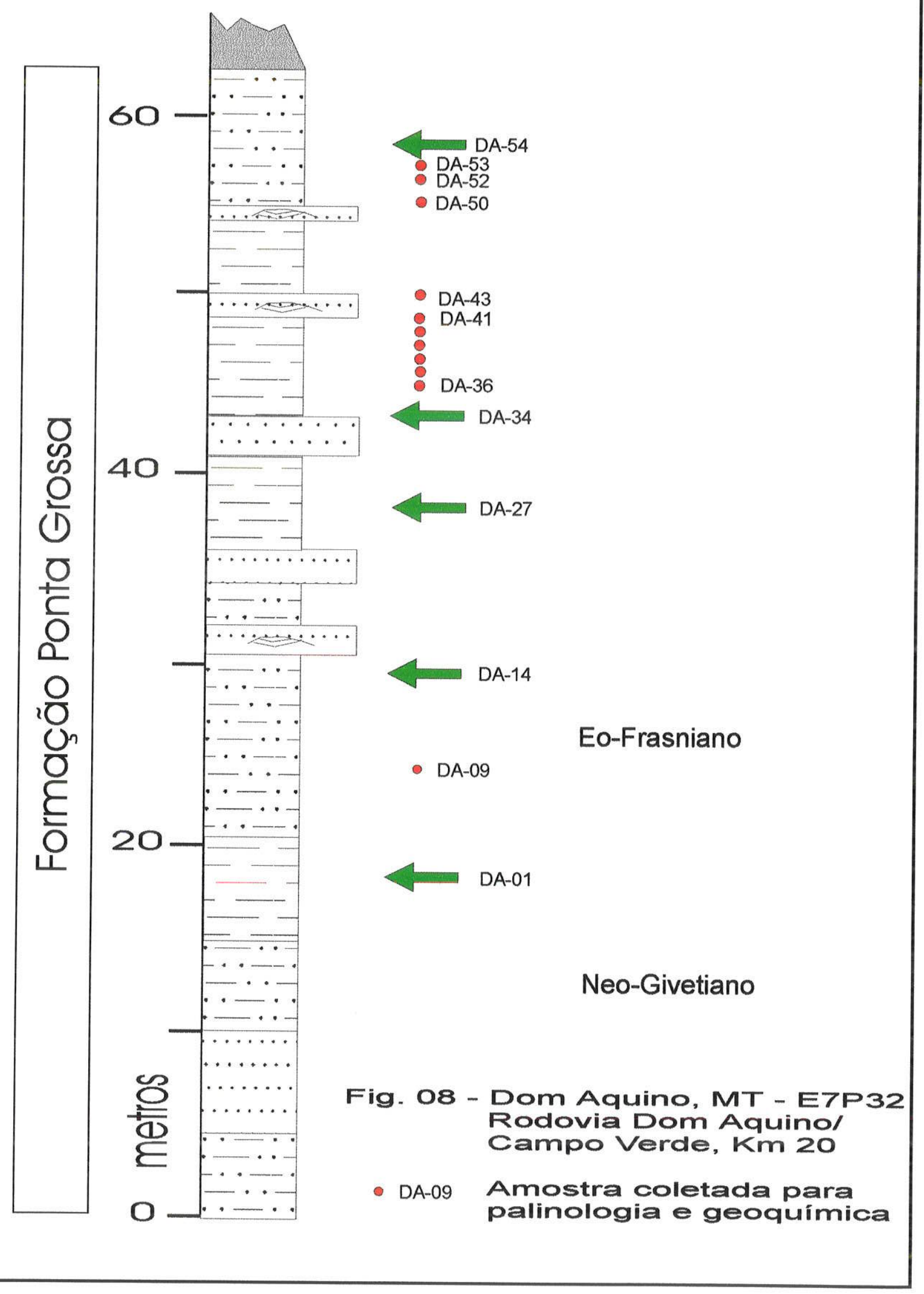


existente na seção e permitem caracterizar a superfície de máxima inundação do Neo-Devoniano na bacia.

\subsubsection{5 - Região de Paranatinga (MT) e Canarana (MT)}

A área estudada entre as cidades de Paranatinga e Canarana está contida no domínio da Bacia do Parecis, segundo Siqueira (1989). Ao longo de toda a região analisada o número de afloramentos é pequeno, normalmente restrito à escarpa de serras que são, invariavelmente, de difícil acesso e encobertas por uma densa vegetação nativa. Nesta região foram visitadas 11 localidades distintas.

No domínio da Serra do Roncador todas as seções estabelecidas demonstram um afinamento do conjunto arenoso basal da seção devoniana, em direção ao embasamento.

$\mathrm{Na}$ localidade da Fazenda Sete de Setembro (13 $51,701^{\prime} \mathrm{S}$ e $52^{\circ}$ $23,540^{\prime}$ W), em uma seção com $5 \mathrm{Km}$ de extensão, é possivel observar o recobrimento sucessivo (onlap) do conjunto arenoso pertencente à Formação Furnas, contra o embasamento (Formação Diamantino). Por sua vez, a seção arenosa é recoberta pelos sedimentos finos, associados à Formação Ponta Grossa, que também assentam-se, diretamente, sobre o embasamento.

Nesta seção, o arranjo estratigráfico (Fig. 09 A e B) demonstra o empilhamento de ciclos retrogradacionais, no contexto de um trato transgressivo, finalizado por um afogamento regional, provavelmente de idade eodevoniana. Os pacotes arenosos apresentam-se intensamente bioturbados por tubos verticais (Sckolytus lineares). A base do conjunto arenoso assenta-se sobre o embasamento através de uma superfície de ravinamento, representada por corpos conglomeráticos. As estruturas sedimentares e $\mathrm{o}$ arranjo estratigráfico permitem 

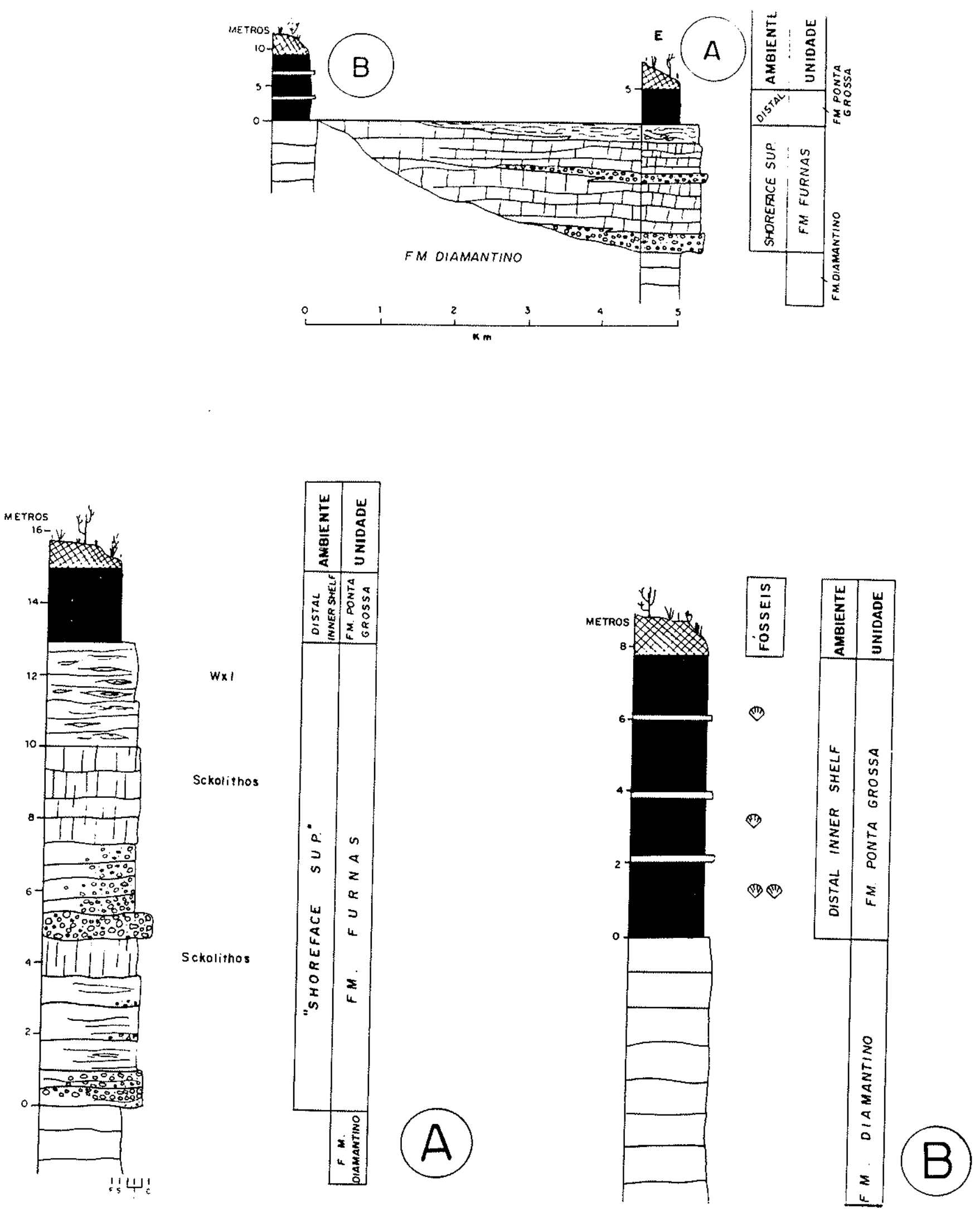

Fig. 09 - Perfis sedimentológicos observados nas regiōes de Paranatinga (MT) e Canarana (MT).

Fig. O9A - Perfil sedimentológico de detalhe realizado na Fazenda Sete de Setembro (13 $51,701^{\prime} S$ e $52^{\circ} 23,540^{\prime}$ $W$ ), demonstrando o recobrimento do conjunto arenoso da Formação Furnas contra o embasamento

Fig. $09 \mathrm{~B}$ - Perfil sedimentológico de detalhe realizado na Fazenda Sete de Setembro (130 $51,701^{\prime} \mathrm{S}$ e $52^{\circ} 23,54 \mathrm{~N}^{\prime}$ W), demonstrando o recobrimento da Formação Ponta Grossa contra o embasamento. 
definir um ambiente marinho raso de deposição para os corpos arenosos observados nesta seção, que são progressivamente substituídos por um ambiente marinho de costa afora (offshore).

Ainda no domínio da Serra do Roncador, em uma escarpa isolada, próximo à Rodoviia BR-158, na altura do município de Canarana, foram descritas duas seções representativas do mesmo intervalo estratigráfico observado na Fazenda Sete de Setembro. A primeira seção (130 40,285' S e $51^{\circ} 59,235^{\prime}$ W) apresenta um arranjo deposicional similar ao observado na Fazenda Sete de Setembro. Esta seção pode ser correlacionada ao último ciclo de empilhamento observado naquela localidade. A mesma possui um caráter retrogradacional, gerado no contexto de um trato transgressivo, limitado por um afogamento regional, provavelmente de idade eodevoniana (Fig. 10B). Nesta localidade são observadas estruturas do tipo hummocky que auxiliam na definição de um ambiente marinho raso para deposição dos sedimentos.

A cerca de $1 \mathrm{Km}$ da localidade anterior, em uma nova escarpa isolada $\left(13^{\circ} 42,008^{\prime} S\right.$ e $\left.52^{\circ} 00,969^{\prime}\right)$, foi levantada uma seção vertical com 30 metros de espessura (Fig. 10A), envolvendo parcialmente o conjunto sedimentar eodevoniano. Esta seção é formada por um conjunto inicial basal composto por arenitos médios a grossos, brancos, portadores de estratificação cruzadas acanalada e planar, arranjados em ciclos de afinamento para o topo, representativo de um sistema deposicional do tipo Braid Delta. As direções de paleocorrente medidas indicam um fluxo principal para Sul/Sudoeste. Este conjunto inicial foi depositado em discordância contra o embasamento, definindo, para o local, uma paraconformidade entre o embasamento e a seção sedimentar. Acima do conjunto sedimentar inicial ocorre um novo ciclo deposicional composto por pacotes arenosos que apresentam-se intensamente bioturbados por tubos verticais (Sckolytus lineares). A base deste conjunto arenoso inicia-se por meio de uma superficie transgressiva, representada por 
Fig. 10 - Perfis sedimentológicos observados nas regiōes de Paranatinga (MT) e Canarana (MT).

Fig. 10A - Seçăo estratigráfica realizada na Serra do Roncador $\left(13^{\circ} 42,008^{\prime}\right.$ S e $52^{\circ} 00,969^{\prime} W$ ) envolvendo o conjunto sedimentar Eo-Devoniano.

Fig. 1OB - Perfil sedimentológico de detalhe realizado na Serra do Roncador $\left(13^{\circ} 40,285^{\prime}\right.$ S e $51^{\circ} 59,235^{\prime} \mathrm{W}$ ), a cerca de $1 \mathrm{~km}$ da seção anterior, apresentando um arranjo similar ao observado na Fazenda Sete de Setembro.

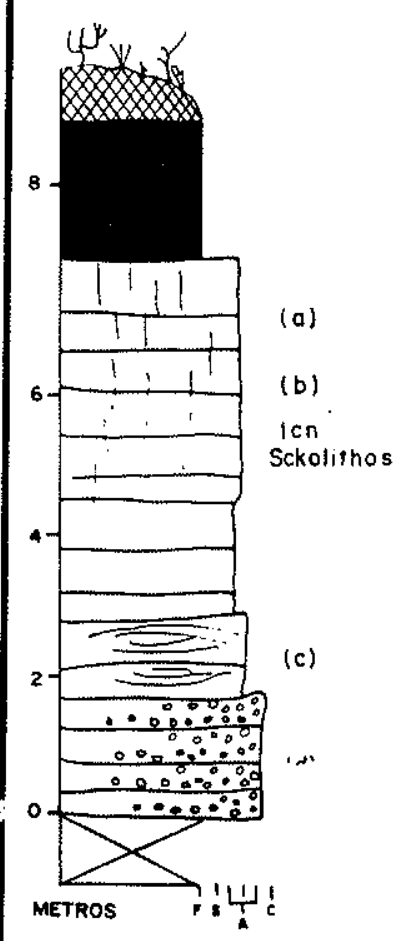

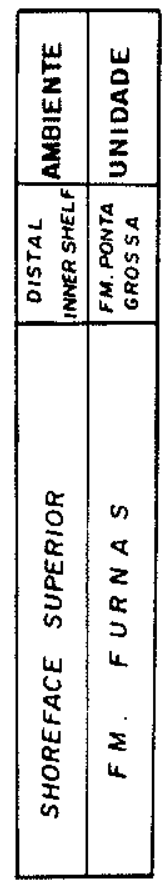

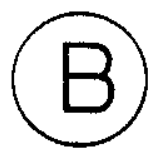

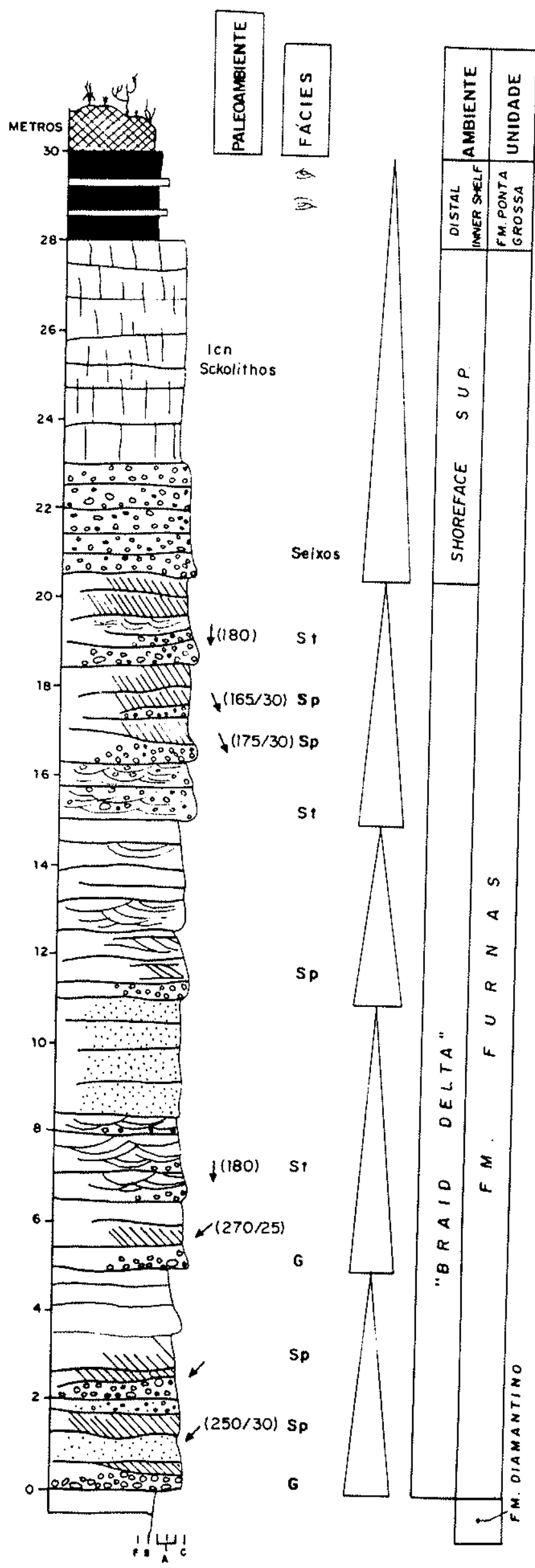


corpos conglomeráticos. Este último ciclo culmina com o registro do afogamento regional de idade, provavelmente, eodevoniana. Este arranjo final pode ser mapeado ao longo da Serra do Roncador e, de certa forma, pode também estar representado na região de Amorinópolis (GO), através dos niveis conglomeráticos observados na base da Formação Ponta Grossa, também definido como o registro de um superfície transgressiva, no sentido de Nummedal \& Swift (1987), por Pereira (1992).

Ainda na área do municipio de Canarana, foram estudados afloramentos isolados representativos da parte inferior da Formação Ponta Grossa (E5-23; E5-24; E5-26; E5-27). Na maioria dos afloramentos, os aspectos sedimentológicos são caracterizados pela presença de ciclos tempestíticos, definidos pelo arranjo de siltitos e arenitos finos, em conjuntos granocrescente ascendente. Em uma única localidade, no município de Canarana, foi descrito um morro testemunho $\left(13^{\circ} 45,329^{\prime} \mathrm{S}\right.$ e $53^{\circ} 03,638^{\prime} \mathrm{W}$ ) composto por arenitos finos a médios, com intercalações de siltitos, portadores de estratificação cruzada por onda, com coloração vermelha intensa. Em termos litológicos estes arenitos assemelham-se aos arenitos vermelhos associados ao Membro Médio da Formação Ponta Grossa, inicialmente observados no sudoeste de Goiás e agora mapeados, também, na borda oeste da Bacia do Paraná.

$\mathrm{Na}$ área do município de Paranatinga existem três localidades bastante significativas do contexto estratigráfico presente na borda sudeste da Bacia do Parecis. Na região da Fazenda Santana da Serra $\left(13^{\circ} 50,790^{\prime} S\right.$ e $53^{\circ}$ $\left.38,130^{\prime} \mathrm{W}\right)$, na escarpa junto à sede da fazenda, em discordância com o embasamento, ocorrem corpos arenosos espessos (Fig.11B) que sustentam as escarpas locais, e que apresentam uma granulometria média a fina, portadores de estratificação cruzada por onda de grande porte. Os mesmos organizam-se em grandes geometrias tabulares composta internamente por corpos tempestíticos amalgamados. Na superfície dessas geometrias observa-se o (?) 


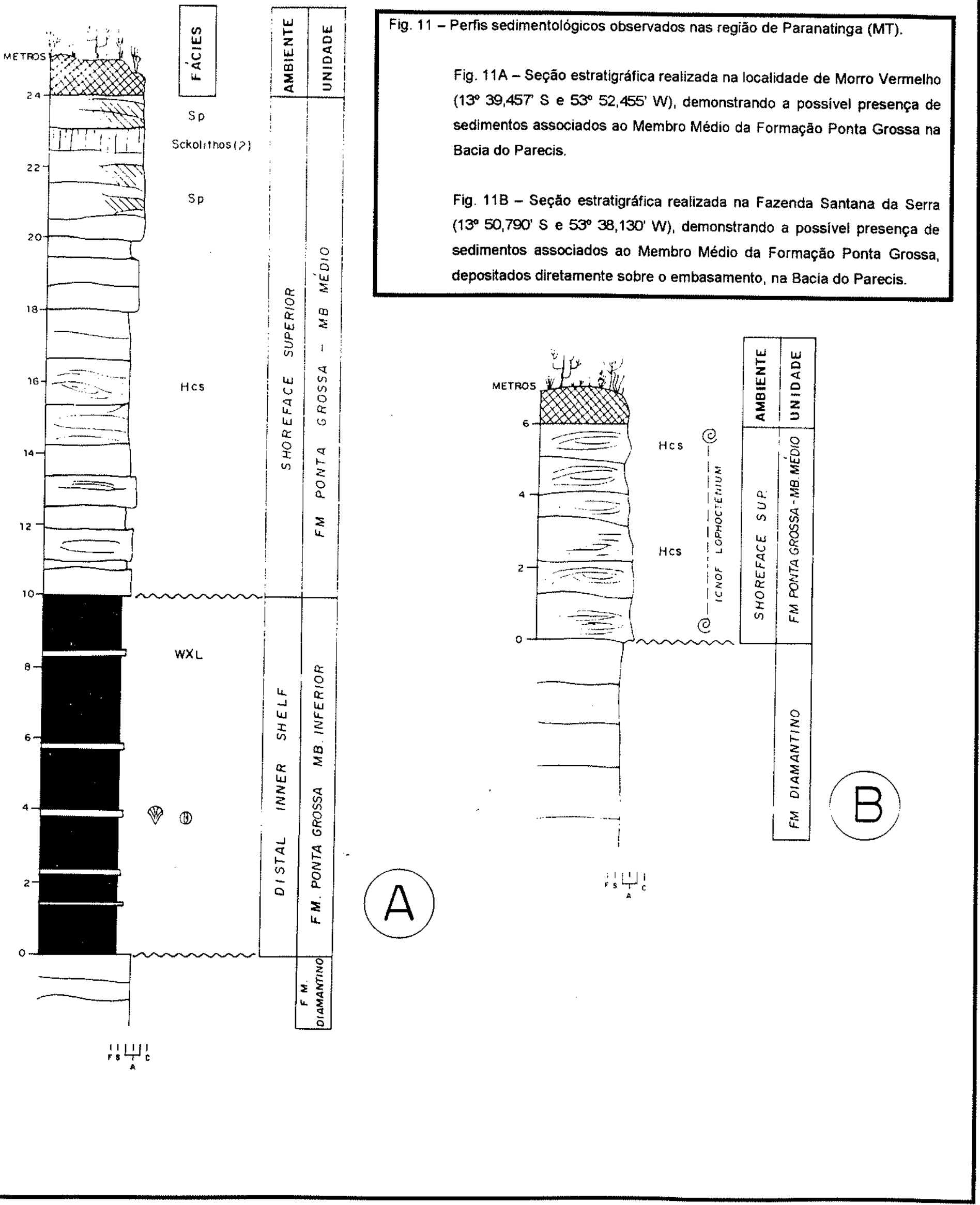


icnogênero Lophoctenium. As características sedimentológicas, pouco comuns para os depósitos do eodevoniano da Formação Ponta Grossa, permitem associar esse conjunto arenoso ao membro Médio da Formação Ponta Grossa.

A possivel presença desta unidade é também discutida na localidade denominada Morro Vermelho na Fazenda do Sr. Jerônimo $\left(13^{\circ} 39,457^{\prime}\right.$ S e $53^{\circ}$ $52,455^{\prime}$ W). Nesta localidade, um pacote sedimentar composto por folhelhos e siltitos, pertencentes à Formação Ponta Grossa, deposita-se diretamente sobre o embasamento. Este pacote, com cerca de 10 metros de espessura é sucedido, de forma brusca, por um conjunto arenoso (Fig. 11A).

Nos sedimentos finos foi observada uma abundante fauna marinha fóssil, composta por invertebrados, associados à fauna Malvinocáfrica. Os invertebrados observados apresentam dimensões, de forma anômala, muito maiores que aquelas observadas em outras áreas da Bacia do Paraná. Embora, não se tenha datado esses sedimentos, o registro de uma fauna malvinocáfrica permite a definição de uma idade Eo-Devoniana para os mesmos.

O conjunto sedimentar que sucede os folhelhos é caracterizado por corpos arenosos de granulometria fina a média, arranjados em ciclos de engrossamento para o topo, apresentando estratificação cruzada por onda (hummocky), estratificação cruzada planar e possiveis icnofósseis do tipo Sckolytus lineares. Esse conjunto sedimentar assenta-se em discordância sobre os folhelhos sotapostos. Em termos deposicionais, estes arenitos podem representar depósitos gerados em ambiente marinho raso, sobre a influência de forte aporte sedimentar.

Estes arenitos foram originalmente mapeados nesta região como pertencentes à Formação Aquidauana por Ribeiro Filho et al. (1975). Por sua vez, Drago et al. (1981), quando da elaboração do Projeto RADAMBRASIL - Folha Goiás (SD-22), redefiniram esses arenitos, associando-os à Formação Utiariti, 
considerada como de idade Neo-Cretácea. Drago et al. (1981) basearam este posicionamento estratigráfico no estudo de Barros et al. (1982), que definiram a Formação Utiariti e a posicionaram no topo da Formação Parecis, a qual foi elevada, por esses mesmos autores, à categoria de Grupo. Segundo Ghignone (1980) a Formação Parecis repousa sobre o derrame basáltico Tapirapuã. Dessa forma, tendo pör base a datação deste basalto, Barros et al. (1982) posicionaram o topo do Grupo Parecis no Cretáceo e, mais precisamente, a Formação Utiariti no Neo-Cretáceo. Aparentemente, Siqueira (1989) recoloca esse pacote arenoso no paleozóico, uma vez que em seu mapa geológico, o autor restringe os sedimentos de idade cretácea à região da Chapada dos Parecis.

Embora existam inúmeras controvérsias sobre o posicionamento estratigráfico dos corpos arenosos observados acima da Formação Ponta Grossa, as características sedimentológicas observadas neste pacote arenoso na localidade do Morro Vermelho, permitem uma associação destes sedimentos ao Membro Médio da Formação Ponta Grossa, de forma alternativa às proposições anteriores. A existência de sedimentos identificados como pertencentes a este membro, em outras áreas da Bacia do Parecis, pode favorecer a proposição apresentada. Contudo, os dados não são suficientes para uma conclusão final.

$\mathrm{Na}$ localidade denominada Morro do Índio (13 $58,522^{\prime} \mathrm{S}$ e $54^{\circ}$ $00,008^{\prime}$ W), ainda na região de Paranatinga, registra-se a presença de sedimentos eodevonianos depositados diretamente sobre o embasamento, composto pela Formação Diamantino. Os sedimentos eodevonianos são representados por uma canga laterítica rica em concreções fossiliferas onde podem ser observados os seguintes fósseis: Australospirifer $s p$. e Orbiculoidea sp., entre outros. Esses sedimentos recobrem as várias escarpas de Serra, formadas pelos metassedimentos da Formação Diamantino.

Na região estudada da Bacia do Parecis, que abrange a Serra do Roncador e do Espanador do Xingu, observa-se um progressivo recobrimento do 
embasamento, em direção a nordeste, por sedimentos de idade Eo-Devoniano. Em toda área estudada o embasamento é constituído pela Formação Diamantino. Este embasamento encontra-se ora basculado, ora em posição sub-horizontal, definindo-se assim situações de paraconformidade ou de discordância angular, quando recoberto pelos sedimentos do devoniano inferior da Bacia do Paraná. Com relação aos sedimentos devonianos, definidos formalmente como formações Furnas e Ponta Grossa, aqueles que são associados à Formação Furnas estão restritos à região da Serra do Roncador, onde recobrem o embasamento e afinam para oeste e nordeste, sendo afogados pelos sedimentos da Formação Ponta Grossa.

2.1.2.6 - Região de Nova Xavantina (MT) e Vale dos Sonhos (MT).

Esta região corresponde ao extremo nordeste da Bacia do Paraná. $\mathrm{Na}$ área estudada foram realizados vários levantamentos geológicos ao longo da Serra Azul, no trecho em que a mesma encontra-se segmentada pelas estruturas do lineamento transbrasiliano. Os resultados obtidos nesta pesquisa foram divulgados por Pereira (1998) e Pereira et al. (1996).

No trabalho de Pereira (1998) foi registrada a ocorrência inédita de sedimentos de origem glacial, associados à Formação Vila Maria, descritos no Córrego Antártico $\left(14^{\circ} 53,168^{\prime}\right.$ 'S e $\left.52^{\circ} 30,275^{\prime} \mathrm{W}\right)$, na região de Nova Xavantina (MT). Este depósito com cerca de 6 metros de espessura assenta-se diretamente sobre o embasamento, sendo sucedido pelos sedimentos da Formação Furnas. Ainda nesta região, na estrada para a fazenda Ouro e Prata ( $14^{\circ} 53,162^{\prime} \mathrm{S}$ e $52^{\circ}$ $27,931^{\prime} \mathrm{W}$ ) é também possivel observar, em afloramentos, o contato entre as formações Furnas e Vila Maria (Fig.12A e B).

Da análise destes sedimentos destacam-se dois aspectos importantes: 1) a existência de uma aparente inter-relação entre os corpos de 
diamictito e os folhelhos sobrepostos, marcada pela presença de fácies rítmıcas, localizadas imediatamente acima do diamictito e 2) a ausência das fácies arenosas, normalmente observadas no topo da Formação Vila Maria.

O primeiro aspecto reforça a idéia de uma relação genética entre a sedimentação glacial e o afogamento marinho, como será demonstrado pela análise do conteúdo palinológico observado em fácies similares a estas em outras localidades. O segundo pode indicar uma perda significativa do conjunto sedimentar associado à Formação Vila Maria, no tempo pré-Furnas, uma vez que mesmo em áreas associadas à borda pretérita da bacia, como no caso de Goiás e da Chapada dos Guimarães, estão presentes espessos pacotes arenosos associados ao topo da Formação Vila Maria.

O trabalho realizado ao longo desta pesquisa no domínio da Serra Azul, entre as regiões de Nova Xavantina (MT) e Vale do Sonho (MT), possibilitou a identificação de um conjunto sedimentar areno-conglomerático, confinado em uma calha de idade provável pós-Devoniano, sendo o mesmo inicialmente descrito por Pereira et al. (1996).

Este conjunto sedimentar, com espessura de pelo menos 100 metros está cartografado nos mapas geológicos disponiveis (e.g. Projeto RADAMBRASIL, 1981, Folha SF 22, Esc. 1:1.000.000) como Formação Furnas. Contudo, seus aspectos sedimentares, bem como as relações estratigráficas locais, impossibilitam tal associação, uma vez que os mesmos apresentam características tectônicas e sedimentares particulares, descritas a seguir, e não relatadas nesta porção da Bacia do Paraná. Além destes aspectos, a presença de fragmentos de rochas da seqüência devoniana inseridas nestes sedimentos, juntamente com os aspectos tectônicos (Lopes-Coelho, em preparação) demonstram que os mesmos foram depositados ao longo de uma calha alinhada na direção WSW, implantada na Bacia do Paraná após a deposição da seqüência devoniana. 
Fig. 12 - Perfis sedimentológicos envolvendo os sedimentos da Formação Vila Maria na região de Nova Xavantina (MT).

Fig. 12A - Perfil sedimentológico envolvendo os sedimentos da Formação Vila Maria, realizado no Córrego Antártico $\left(14^{\circ} 53,168^{\prime}\right.$ 's e $52^{\circ} 30,275^{\prime}$ W).

Fig. 12B - Perfil sedimentológico envolvendo os sedimentos da Formaçåo Vila Maria, realizado na estrada para a Fazenda Ouro e Prata $\left(14^{\circ} 53,162^{\prime}\right.$ S e $52^{\circ} 27,931^{\prime} W$ ).
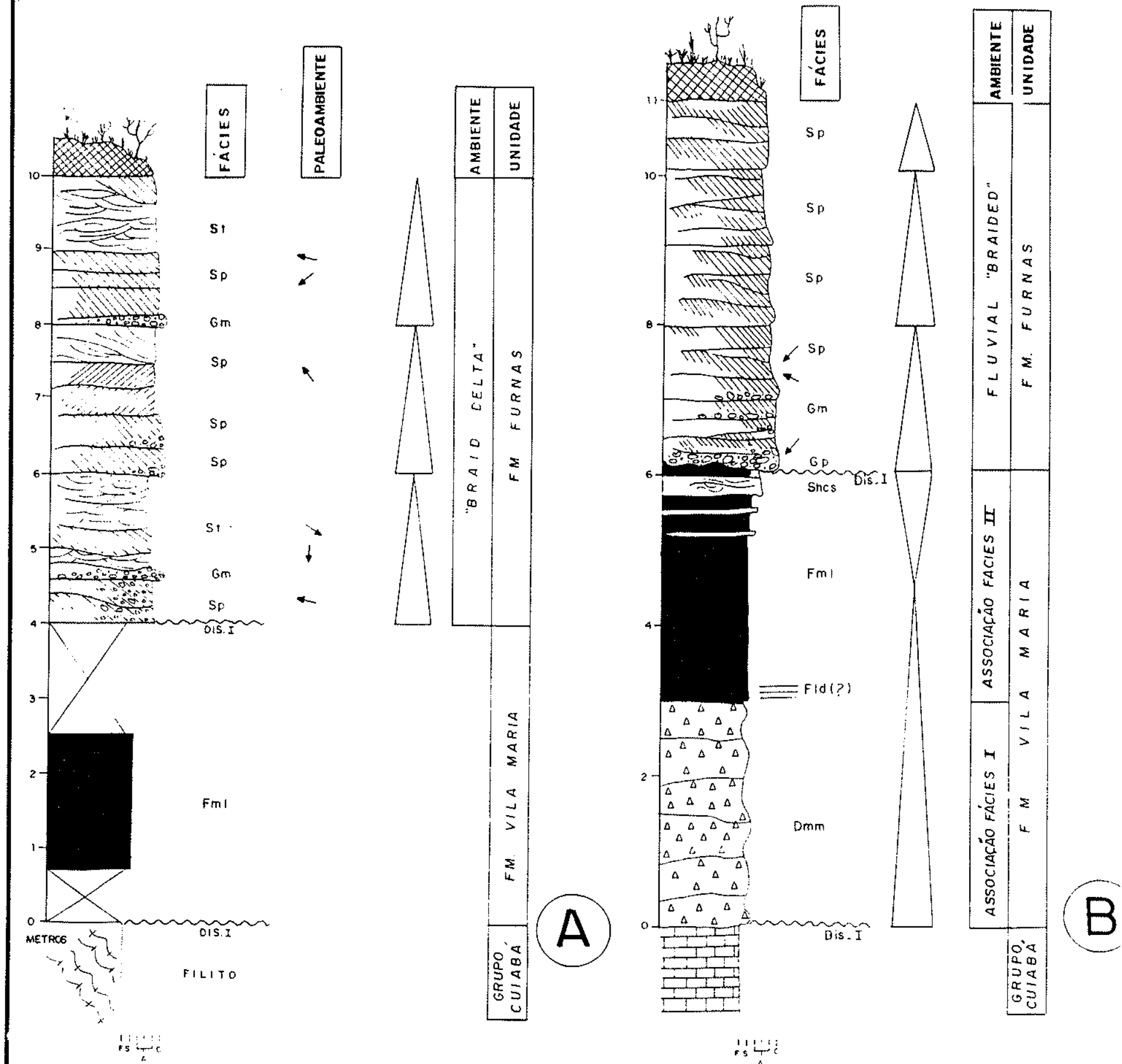

I' 
Esses sedimentos foram inicialmente agrupados por Pereira et al. (1996) em uma nova unidade denominada Vale dos Sonhos, no entanto a continuidade das pesquisas demonstraram que esses sedimentos estão associados à Formação Aquidauana (Lopes-Coelho, em preparação). Os mesmos encontram-se expostos ao longo dos escarpamentos da Serra Azul, entre as localidades de Vale dos Sonhos e Nova Xavantina, sendo que as melhores exposições ocorrem nas escarpas da Serra Azul que margeiam a BR-158.

Os sedimentos descritos na seção da Serra Azul ocorrem controlados por falhamentos normais associados à Zona de Falha Transbrasiliana (senso Zalán et al., 1990), desenvolvendo-se nitidamente ao longo de uma calha de direção WSW /ENE. Esta calha possui uma dimensão transversal de cerca de $33 \mathrm{Km}$ e dimensão longitudinal mínima de $40 \mathrm{Km}$.

A sul e a norte da zona de falha, respectivamente, na Serra do Taquaral em Barra do Garças e na região da Fazenda Ouro e Prata no município de Nova Xavantina, observa-se um arranjo estratigráfico normal das seqüências siluriana e devoniana da Bacia do Paraná, compostas, respectivamente, pela Formação Vila Maria e pelas formações Furnas e Ponta Grossa. Ao longo da calha, no entanto, estas seqüências estão ausentes por erosão, encontrando-se os sedimentos, agora associados à Formação Aquidauana, assentados diretamente sobre o embasamento.

Os sedimentos descritos são agrupados por Pereira et al. (1996) em dois ciclos tectono-sedimentares, marcados pelo domínio de litofácies rudáceas. $\mathrm{O}$ primeiro ciclo é definido pela presença dominante de corpos canalizados de ortoconglomerados (fácies $\mathrm{Gm}$ ), compostos por seixos e matacões de fragmentos de rocha com até $50 \mathrm{~cm}$ na dimensão maior (filitos, quartzitos, ígneas e sedimentares), angulosos a subangulosos (Fig. 13 c, b, d). Estes corpos intercalam-sø e interdigitam-se com arenitos finos a médios, laminados ou com 
ondulações truncantes (Shcs). Ocorrem ainda níveis sílticos laminados, centimétricos, ao longo deste primeiro ciclo.

O segundo ciclo sedimentar é marcado pelo domínio de litofácies do tipo Gm, Gp e Gt, agrupadas em corpos canalizados com cerca de 3 metros de espessura média (Fig. 13 a, d). Tais litofácies são caracterizadas por arenitos grossos a conglomeráticos, exibindo níveis de conglomerados organizados, compostos por seixos decimétricos de fragmentos de rocha. Os seixos são extremamente bem arredondados, mostrando razoável seleção. Estes arenitos/conglomerados são portadores de estratificações cruzadas do tipo acanalada e tabular. Nos níveis conglomeráticos, observa-se uma gradação inversa, em um contexto de ciclos de afinamento normal. Em direção ao topo da seção, intensificam-se os ciclos de afinamento normal, passando a predominar fácies arenosas grosseiras portadoras de estratificações cruzadas acanalada e tabular (fácies St e Sp, respectivamente).

O primeiro ciclo sedimentar assenta-se discordantemente sobre os filitos do Grupo Cuiabá, gerando uma discordância angular, marcada por profundas incisões nos filitos. Neste ciclo, nota-se claramente o controle tectônico da sedimentação, indicado pela recorrência de níveis conglomeráticos, compostos por fragmentos angulosos e imaturos do embasamento cisalhado. $\mathrm{O}$ arranjo das litofácies indica que os sedimentos foram depositados por fluxos gravitacionais de alta densidade (fácies F1 e F2 de Mutti, 1992), em um corpo aquoso sujeito à ação de ondas. A geometria dos sedimentos deste ciclo sugere deposição em vales incisos.

Os sedimentos do segundo ciclo foram gerados ainda em um contexto tectônico ativo e representam a implantação na calha de um sistema de leques aluviais, marcado pela migração, em direção a oeste/sudoeste, de formas de leito arenosas e conglomeráticas de grande porte. Estes sedimentos, em contato brusco com aqueles do primeiro ciclo, preenchem os vales incisos iniciais 


\begin{tabular}{|c|c|c|c|}
\hline JOVOINก & $\forall N \forall \cap \nabla 01 \cap 0 \forall$ & $w y$ & $\begin{array}{l}\text { Yevino } \\
\text { Odnug }\end{array}$ \\
\hline 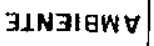 & $7 \forall 1 \wedge \cap 7 \forall$ & $3 \cap 037$ & 011714 \\
\hline
\end{tabular}

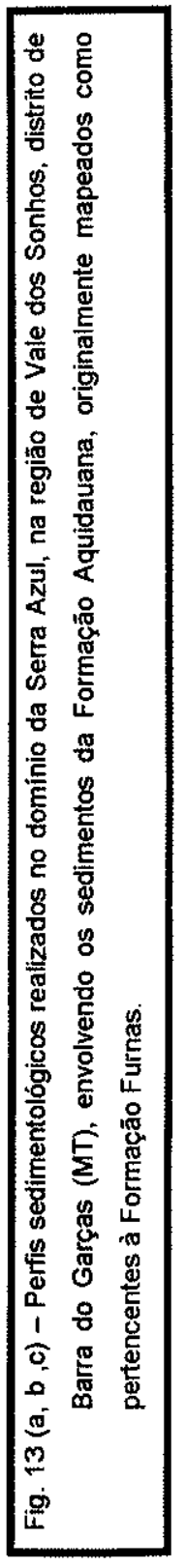

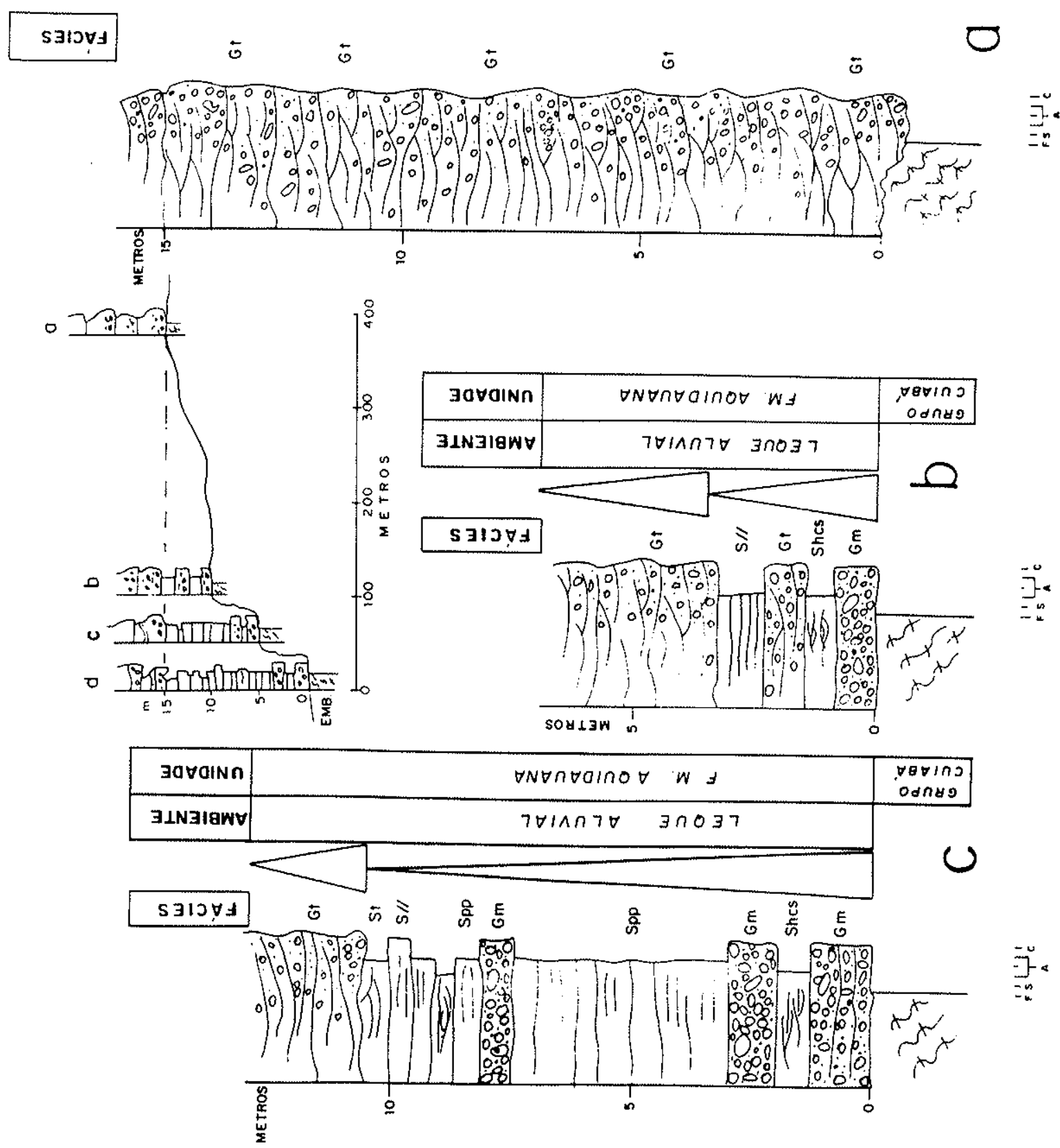


Fig. 13 (d) - Perfil sedimentológico realizado no domínio da Serra Azul, na regiáo de Vale dos Sonhos, distrito de Barra do Garças (MT), envolvendo os sedimentos da Formaçāo Aquidauana, originalmente mapeados como pertencentes à Formação Furnas.

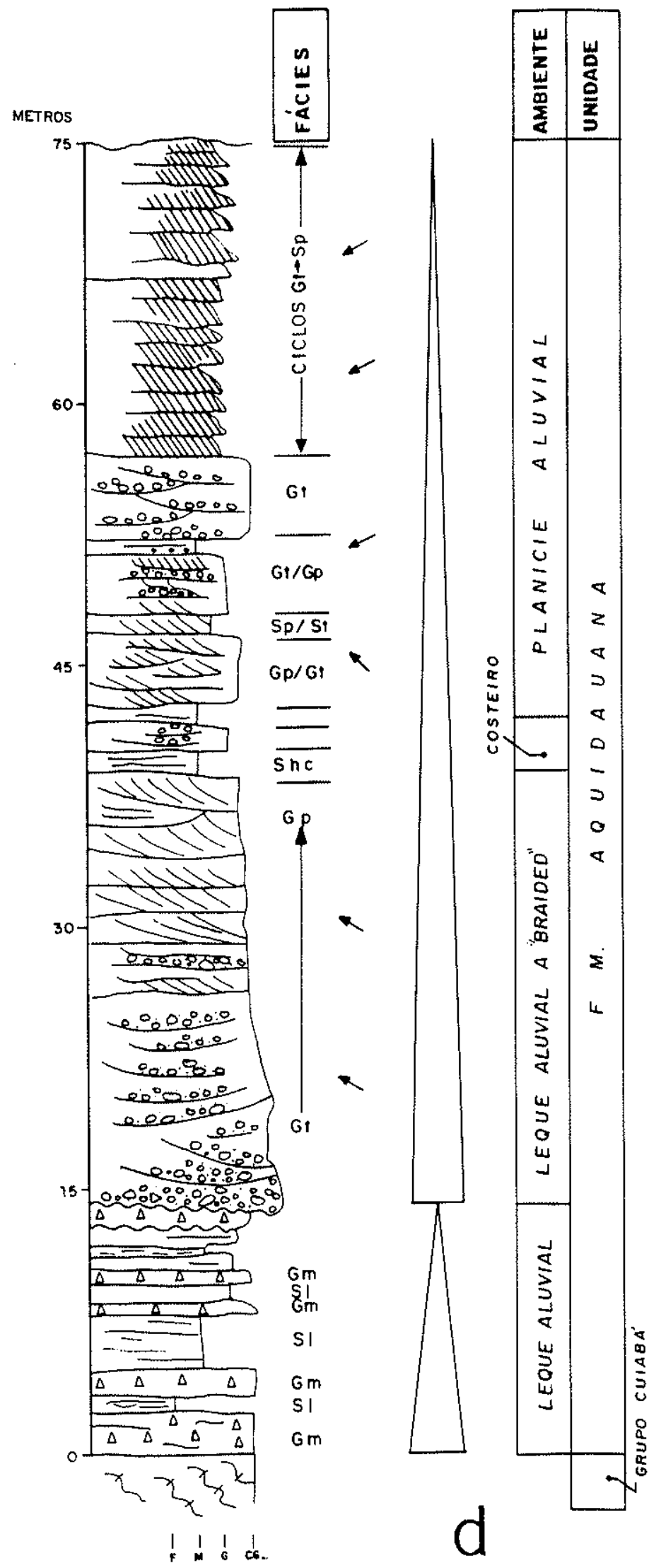


"onlapando" suas bordas e podendo então assentar-se discordantemente sobre o embasamento. A diminuição da atividade tectônica leva a um generalizado afogamento, marcado por um intervalo contínuo com cerca de 5 metros de espessura, constituído por pacotes de arenitos finos a médios com laminações onduladas truncantes e pistas fósseis (icnogênero Planulites). A retomada do aporte sedimentar provoca uma nova implantação, na calha deposicional, de condições deposicionais de leque aluvial.

Assim, parte dos sedimentos até então mapeados como Formação Furnas no domínio da Serra Azul, na região de influência da Zona de Falha Transbrasiliana, são oportunamente definidos como pertencentes à Formação Aquidauana e entendidos como depositados sobre um ativo controle tectônico exercido por estruturas herdadas do embasamento.

2.1.2.7 - Região de Barra do Garças (MT) e General Carneiro (MT).

$\mathrm{Na}$ região de Barra do Garças estão registrados depósitos associados às seqüências mais antigas da bacia, representados pelas formações Vila Maria, Furnas e Ponta Grossa. Segundo Milani et al. (1995), ainda nesta região, são descritos afloramentos da Formação Alto Garças na escarpa do Morro do Cristo na cidade de Barra do Garças. Contudo, a seção assinalada como Formação Alto Garças em afloramentos da escarpa do Morro do Cristo foram interpretadas como associadas à Formação Furnas por Pereira et al. (1995a). Alvarenga et al. (1998) também interpretam os arenitos aflorantes na escarpa do Morro do Cristo como pertencentes à Formação Furnas. Assine et al. (1994), apontam como seção de referência para a Formação Alto Garças, na mesma localidade, a seção de diamictitos, arenitos e ortoconglomerados expostos na região do Morro do Cristo, abaixo do nível de siltitos e arenitos finos de Formação Vila Maria. No entanto, Rodrigues et al. (1995) associam este intervalo à 
Formação Vila Maria, incluindo este pacote no contexto de fácies de diamictitos e conglomerados desta unidade.

No recente trabalho de Alvarenga et al. (1998), envolvendo a região de Barra do Garças, os autores restringem a ocorrência desta unidade a um conjunto de arenitos grossos com estruturas canalizadas e de escorregamento, e espessura em torno de 20 metros, expostos no Córrego Avoadeira - Piscinas da Loca. Estes autores admitem uma influência glacial na deposição deste pacotes arenosos, bem como advogam que no sudoeste de Goiás e leste de Mato Grosso não há evidências de descontinuidade entre os arenitos da Formação Alto Garças e os diamictitos, definidos pelos autores como Formação lapó.

Esta inter-relação de fácies entre arenitos e diamictitos já havia sido diagnosticada para estas mesmas regiões por Pereira $(1992,1998)$ e por Rodrigues et al. (1995). No entanto, esses autores englobam esse conjunto sedimentar na Formação Vila Maria, conforme a descrição original de Faria (1982), e por entenderem que a variação faciológica marcada ora pelo domínio de fácies arenosas ora pelo domínio de fácies de diamictito é uma decorrência direta da dinâmica deposicional.

Por outro lado, Alvarenga et al. (1998) argumentam que os arenitos, abaixo dos diamictitos e conglomerados, constituem-se em uma unidade litológica reconhecivel e mapeável, podendo então ser considerada uma unidade litoestratigráfica distinta. Os autores ainda discutem que a relação genética entre os arenitos e os diamictitos não constituem um argumento contrário para a classificação dos arenitos basais dentro da Formação Alto Garças, pois gênese não é critério para a definição de unidades litoestratigráficas. Contudo, devemos entender que na nova ótica estratigráfica os corpos sedimentares são individualizados por suas relaçōes genéticas, sendo os mesmos formalmente individualizados em unidades aloestratigráficas (Miall, 1990). Nesse sentido, individualizar em uma mesma unidade litoestratigráfica corpos sedimentares 
depositados em contextos tectonicos e deposicionais distintos, nos leva a situação de ter que se descrever uma discordância no interior de uma unidade litoestratigráfica, como seria o caso da Formação Alto Garças.

Dessa forma, na região de Barra do Garças entendemos que o melhor arranjo estratigráfico foi apresentado por Rodrigues et al. (1995), a partir de seções elaboradas na subida do Morro do Cindacta (Fig. 14A), na cidade de Barra do Garças ( $15^{\circ} 51,157^{\prime} S$ e $52^{\circ} 16,357^{\prime} W$ ) e na Serra do Taquaral, localizada à margem da rodovia BR-158 (15 $44,727^{\prime} S$ e $\left.52^{\circ} 17,828^{\prime} W\right)$, na área rural de Barra do Garças (Fig. 14B).

Na região de General Carneiro, os aspectos estratigráficos não diferem em muito daqueles observados na área de Barra do Garças. No entanto, nesta região foi possível mapear em algumas localidades sedimentos relacionados ao Membro médio da Formação Ponta Grossa. Na localidade da Fazenda Passa Vinte $\left(15^{\circ} 40,92^{\prime} S\right.$ e $52^{\circ} 41,28^{\prime} W$ ) esses sedimentos são compostos por arenitos grossos a conglomeráticos, arranjados em ciclos tempestíticos, de caráter proximal, agrupados em parasseqüências com arranjo granulométrico inverso (ciclos de granulocrescência ascendente) (Fig. 15A e B). Sedimentos similares àqueles do membro médio da Formação Ponta Grossa foram descritos na região de Barra do Garças por Andrade (1988). Essa nova identificação na Fazenda Passa Vinte e arredores reforça a possibilidade de mapeamento dessa unidade por toda a parte norte da Bacia do Paraná. 

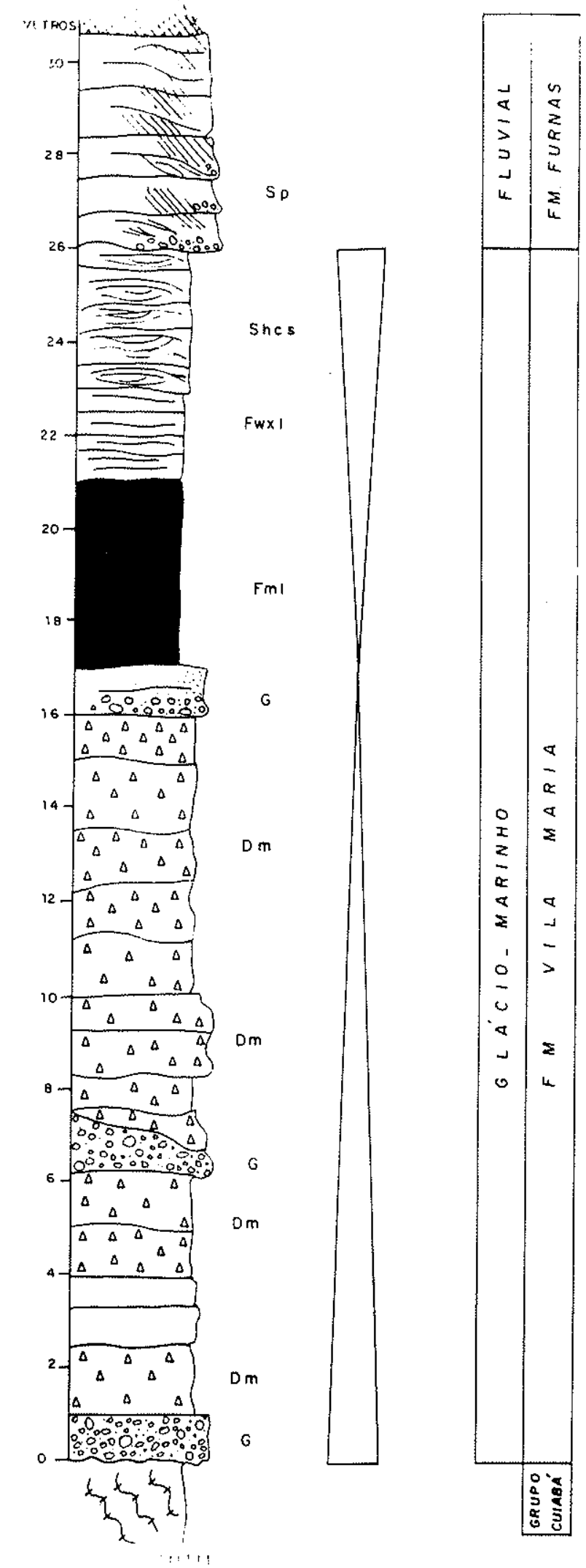

Fig. 14 - Perfis sedimentológicos envolvendo os sedimentos da Formaçăo Vila Maria na região de Barra do Garças (MT).

Fig. 14A - Perfil sedimentológico, modificado de Rodrigues et al, 1995, envolvendo os sedimentos da Formação Vila Maria, realizado na subida do Morro do Cindacta, na cidade de Barra do Garças $\left(15^{\circ} 51,157^{\prime} \mathrm{S}\right.$ e $52^{\circ} 16,357^{\prime} W$ ).

Fig. 14B - Perfil sedimentológico, modificado de Rodrigues et al., 1995, envolvendo os sedimentos da Formação Vila Maria, realizado na Serra do Taquaral, no municipio Barra do Garças (15 $44,727^{\prime}$ S e $52^{\circ} 17,828^{\prime}$ W).

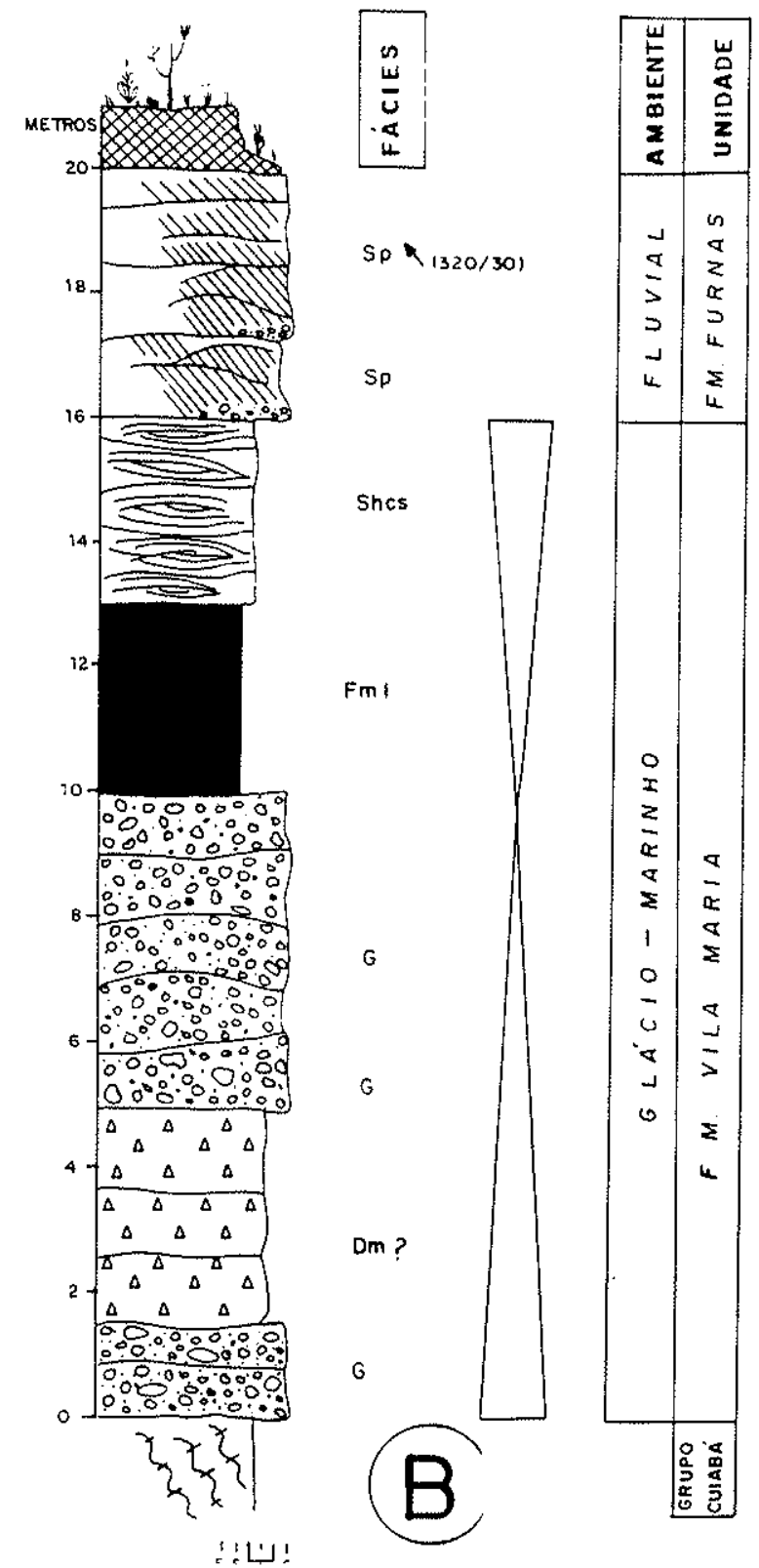


2.1.2.8 - Região de Torixoreú (MT), Pedra branca (MT) e Araguainha (MT).

Esta região da bacia foi estudada a partir de um levantamento realizado ao longo da margem oeste do Rio Araguaia, que teve início na cidade de Alto Araguaia (MT) e término na cidade de Pontal do Araguaia (MT). Ao longo deste levantamento foram realizadas seções na área do domo de Araguainha, no município de Pedra Branca, e nos arredores da cidade de Torixoreú.

A região do Domo de Araguainha é, sem dúvida, o ponto mais interessante e complexo deste levantamento. $O$ "Domo de Araguainha" foi descrito inicialmente por Northfleet et al. (1969), que o consideraram como uma estrutura geológica gerada por uma intrusão sienítica relacionada ao magmatismo cretácico da Bacia do Paraná. Estes autores descrevem esta estrutura como associada a uma intrusão perfurante de rocha sienítica que arqueou as camadas paleozóicas adjacentes na forma de um domo. Ainda segundo Northefleet et al. (1969), a estrutura gerada possui uma forma circular com aproximadamente $40 \mathrm{Km}$ de diâmetro, ocorrendo numa "sinclinal periférica" grabens semi-circulares com remanescentes de rochas permianas. Similar interpretação foi dada por Gonçalves \& Schneider (1970), que descreveram os principais constituintes do núcleo cristalino. Segundo Theilen-Willige (1981) os principais constituintes descritos por Gonçalves \& Schneider (1970) são: quartzo, feldspato alcalino, diopsídio, augita, biotita, muscovita, apatita, horneblenda e turmalina.

Ainda segundo Theilen-Willige (1981), os autores Silveira Fitho \& Ribeiro (1971) e Spector et al. (1972; apud Theilen-Willige,1981) descreveram o "Domo de Araguainha" como um bloco alto do embasamento no centro de uma estrutura circundada por um anel de brechas vulcânicas e tufos, gerado por uma intrusão criptovulcânica. 


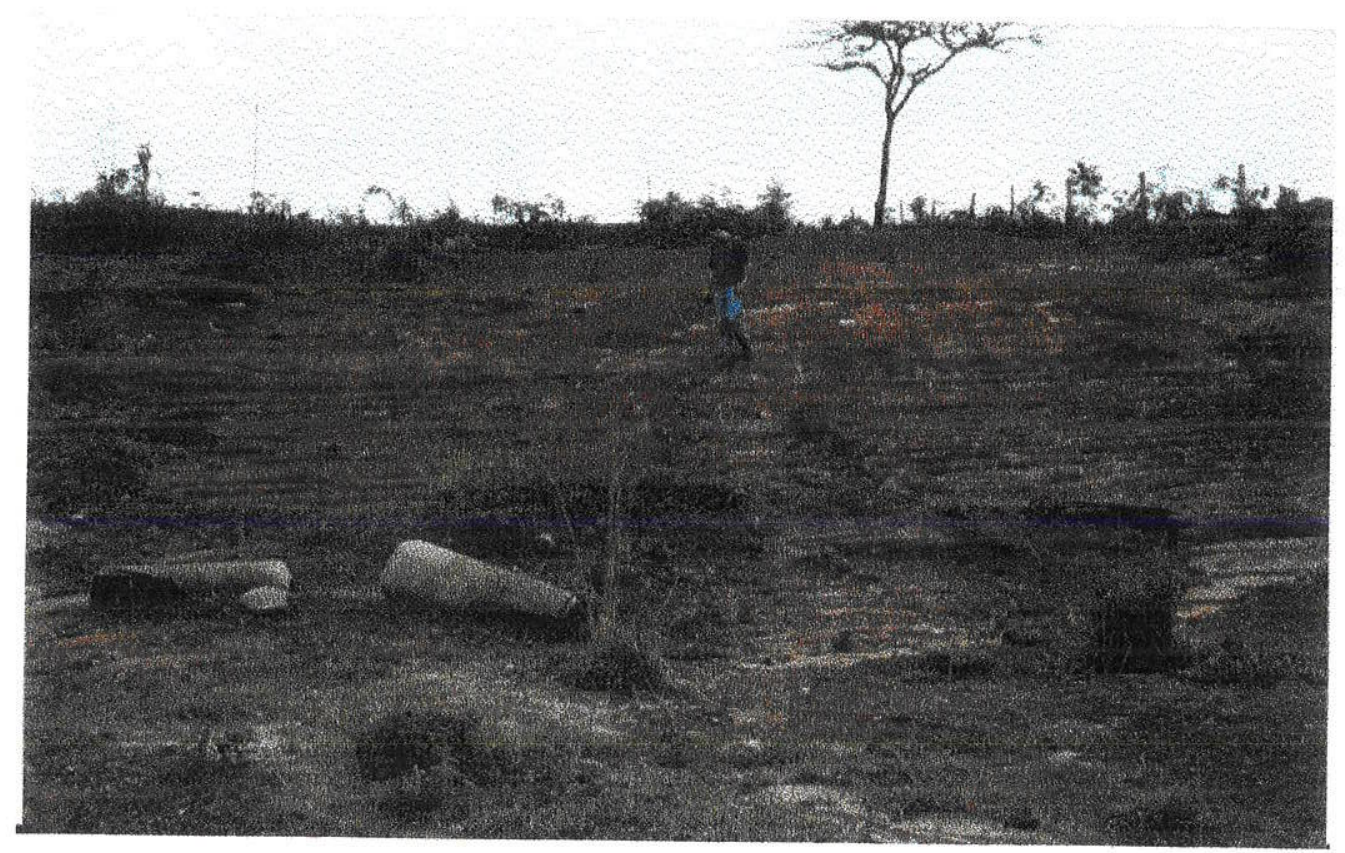

$15 \mathrm{~A}$

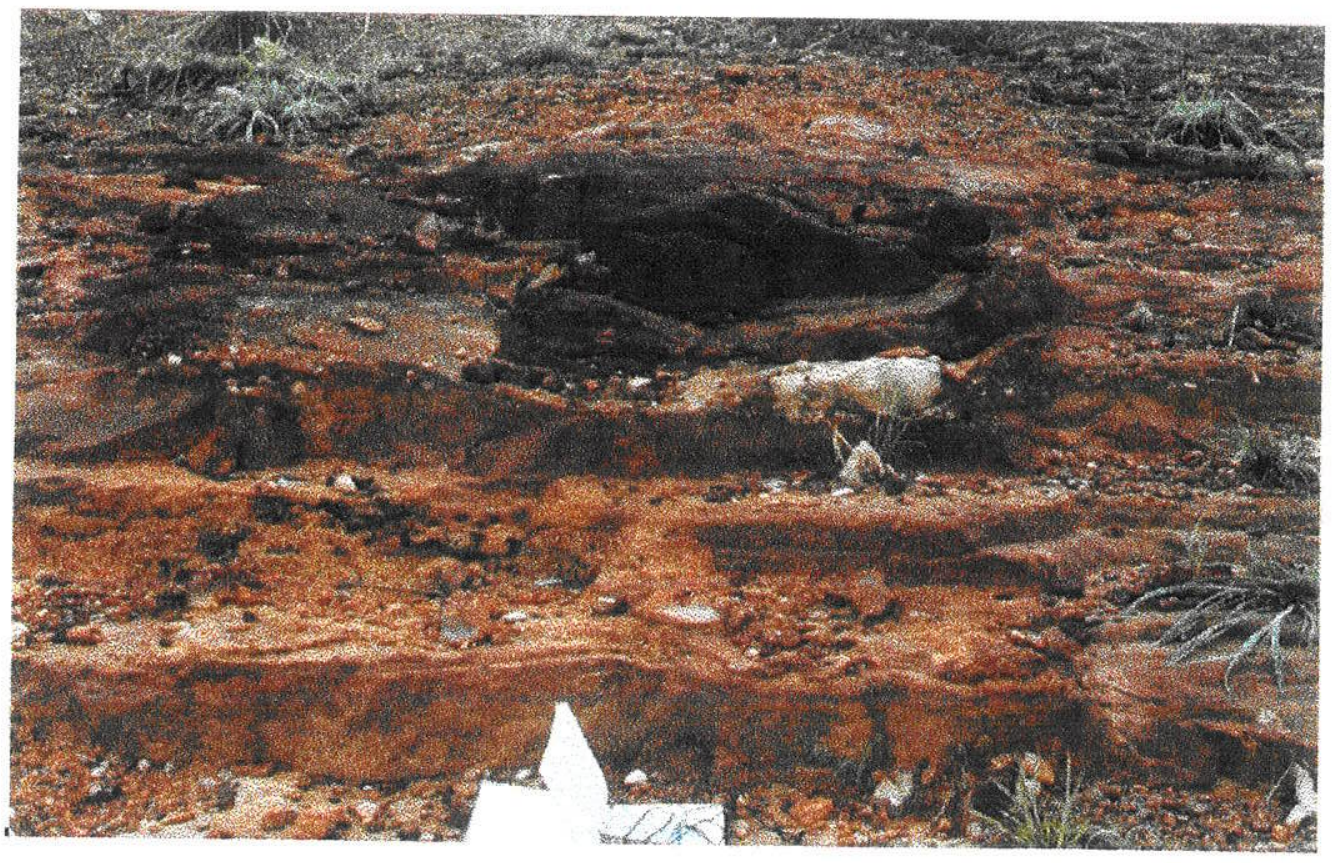

15B

Fig. 15 - Aspectos sedimentológicos do Membro Médio Formação Ponta Grossa, observados na região de General Carneiro (MT).

A) Aspecto geral dos sedimentos associados ao Membro Médio da Formação Ponta Grossa, na localidade de Fazenda Passa Vinte $\left(15^{\circ} 40,92^{\prime} \mathrm{S}\right.$ e $52^{\circ} 41,28^{\prime} \mathrm{V}$ ); B) Detalhe da foto anterior. 
A primeira associação da gênese do "Domo de Araguainha" a um impacto de meteorito foi apresentada por Dietz et al. (1973). Segundo esses autores, embora esta estrutura tenha sido inicialmente considerada como o registro de uma intrusão alcalina, as feições características de um metamorfismo de impacto indicam que a mesma é um astroblema. Dietz et al. (1973) descrevem a estrutura como constituída por um bloco central soerguido, com mais de $10 \mathrm{Km}$, circundado por um anel de grabens abatidos em um sinclinal periférico. $O$ diâmetro total, a partir de imagens do tipo ERTS, é de $40 \mathrm{Km}$. Ainda segundo os autores, o núcleo central soerguido é composto por uma brecha de rochas do embasamento cristalino circundada por uma matriz ígnea, provavelmente uma rocha do tipo suevito (rocha fundida por impacto). Um anel de quartzito cataclástico (Formação Furnas) circunda o alto central, sendo que nestes os grãos de quartzo estão comumente destruídos. A análise de lâminas delgadas, obtidas pelos autores a partir do núcleo central, revela abundantes efeitos do metamorfismo de impacto, especialmente estruturas com ornamentação planar em grãos de quartzo.

Theilen-Willige (1981) afirma que a hipótese do Domo de Araguainha ter sido produzido por um impacto de meteorito pode ser comprovada pela investigação petrográfica. A autora descreve a presença de um núcleo cristalino na área central do domo composto por rochas hipidiomórficas e parcialmente pórfiras, com características alcali-granítica e alcali-sienítica. Nestas rochas são identificadas estruturas de deformação em grãos de quartzo (estruturas de deformação planar); em biotitas (kinkbands) e em plagioclásios (pequenos deslocamentos, rotações, fraturas e falhas), que são interpretadas pela autora como o resultado de um metamorfismo de impacto. Pelas características das estruturas observadas, onde a textura primária da rocha está preservada, TheilenWillige (1981) acredita que as rochas cristalinas afetadas deveriam estar em subsuperficie quando do impacto. Assim, esta autora conclui que, aparentemente, o núcleo cristalino do complexo circular de Araguainha representa um bloco do embasamento que foi levantado por um movimento centripeto a partir da periferia 
da estrutura em direção ao núcleo central soerguido. Contudo, a autora ressalta que a elevação do embasamento pré-cambriano já poderia ter ocorrido antes do impacto. A hipótese de metamorfismo de impacto é reforçada, segundo a autora, pela presença de estruturas do tipo "shatter-coned", rochas do tipo suevito e brechas polimíticas, que ocorrem na região de contato entre o núcleo do embasamento "e os sedimentos paleozóicos.

Nesta mesma linha de análise, Crósta et al. (1981), a partir do exame de feições macro e microscópicas exibidas por amostras descritas no local, concordam que o Domo de Araguainha tenha se formado pelo impacto de um corpo celeste de grandes dimensões como proposto por Dietz et al. (1973).

Em recente trabalho, Lana et al. (1999) descrevem que no centro do astroblema de Araguainha existe um levantamento composto por rochas graniticas circundada por arenitos fraturados enriquecidos em Fe. Os autores descrevem ainda a existência de um anel de brechas polimíticas, composto predominantemente por fragmentos de rochas sedimentares, que ocorre ao longo do contato entre o núcleo granítico e os arenitos.

Pelos relatos observados na literatura, o núcleo central do Domo de Araguainha seria composto por rochas do embasamento de composição ignea, as quais seriam circundadas por um anel de rochas produzidas pelo impacto de um meteorito. Estas, geradas no processo de impacto, estariam por sua vez circundadas pelas rochas sedimentares paleozóicas. Estas observações diferem daquelas apresentadas por Oliveira (1977).

No trabalho de Oliveira (1977) pode ser observada uma minuciosa descrição de campo da estrutura de Araguainha. Este autor interpreta o domo como um astroblema, em função das várias estruturas de deformação observadas e que foram interpretadas pelo autor como relativas a um metamorfismo de impacto. 
$\mathrm{Na}$ descrição de Oliveira (1977) são definidos dois conjuntos de rochas: um conjunto composto pelas rochas do núcleo da estrutura e outro pelas rochas encaixantes. As rochas do núcleo são classificadas como: (1) rocha porfiritica interior, (2) brecha soldada, (3) zonas brechoides com estrutura fluidal e (4) rochas de ejetamento. A rocha porfirítica constitui-se em uma rocha macroscopicamente semelhante a um sienito pórfiro, de granulação média, com fenocristais. $O$ autor ainda relata a presença de xenólitos de natureza variada, inclusive arenito metamorfisado e filito ardosiano, mais abundantes nas proximidades da borda da cratera, mas não confinados a esta posição. A descrição mineralógica apresentada por Oliveira (1977) é semelhante àquela descrita por Gonçalves \& Schneider (1970). Contudo o autor identifica xenólitos, pequenos fragmentos de rocha e fenocristais de feldspato, entre outras características que o levaram a sugerir que a rocha encontrada poderia ser em realidade o resultado da evolução de uma brecha, onde a maioria dos componentes mineralógicos estão recristalizados. Oliveira (1977) ainda comenta que a rocha porfirítica da área central da estrutura passa de forma gradual para a brecha soldada, que a circunda. Esta brecha soldada tem um aspecto maciço, com a aparência de uma rocha ígnea. Dentro da faixa anelar da brecha soldada ocorrem zonas tabulares com estrutura fluidal.

As descrições apresentadas por Oliveira (1977) para as rochas que compõem o núcleo da estrutura de Araguainha diferem francamente dos relatos de Lana et al. (1999), Theilen-Willige (1981) e Crósta et al. (1981). Esses autores associam o centro da estrutura a um núcleo cristalino do embasamento, enquanto que as observações de Oliveira (1977) demonstram que essas rochas são geradas durante a formação da estrutura. Esta posição fica ainda mais clara quando da descrição do segundo grupo de rochas observado por Oliveira (1977) na região e denominadas como rochas encaixantes. Na descrição do autor essas rochas são composta; (1) pelo embasamento metamórfico formado por um conjunto de rochas com baixo metamorfismo, atribuíveis ao Grupo Cuiabá; (2) 
pela sequêencia clástica pré-Furnas; (3) pela Formação Furnas; (4) peła Formação Ponta Grossa e (5) pelas demais unidades do pacote paleozóico. Assim, segundo Oliveira (1977), as rochas do embasamento ocorrem formando um anel externo à faixa de brecha, sendo que as demais unidades vão decrescendo em ordem de idade a partir do núcleo, o que conhecide com a ordem segundo a qual as respectivas faixas de afloramentos se afastam da cratera central.

As observações que realizamos no local apresentam características semelhantes àquelas mencionadas por Oliveira (1977). Em uma seção levantada a cerca de $2 \mathrm{Km}$ da área central do Domo de Araguainha $\left(16^{\circ} 48,275^{\prime} \mathrm{S}\right.$ e $53^{\circ}$ $00,058^{\prime}$ W) observamos a existência de um pacote sedimentar composto por conglomerado suportado por matriz, apresentando diversos fragmentos de rocha de composição ígnea e metabásica, como também quartzitos e filitos (Fig. 16A). Alguns seixos podem atingir até $20 \mathrm{~cm}$, em sua maior dimensão. A matriz é argilosa de coloração vermelha, apresentando por vezes grânulos de quartzo dispersos. Este conjunto encontra-se deformado e fraturado, sendo o mesmo depositado de maneira não organizada. Os sedimentos estão depositados em discordância com o embasamento, que no local é constituído por filito grafitoso e quartzitos dobrados. Em relação ao centro do domo, o conjunto de rochas composto pelo embasamento metamórfico e pelo pacote sedimentar conglomerático encontra-se distribuído lateralmente, aparentemente acompanhando a estrutura circular da parte central do domo. Este conjunto localiza-se em uma posição intermediária entre o centro da estrutura e a Formação Furnas, a qual está disposta em uma posição radial mais periférica em relação ao núcleo do domo. Contudo, o contato entre o pacote de sedimentos conglomeráticos com a Formação Furnas não foi observado.

Assim, a questão mais interessante entre as descrições da literatura e as nossas observações é a atribuição de um embasamento granítico na área do domo. A existência de um núcleo granítico, associado ao embasamento nesta área, teria que ser entendida como a representação de um complexo de rochas do 

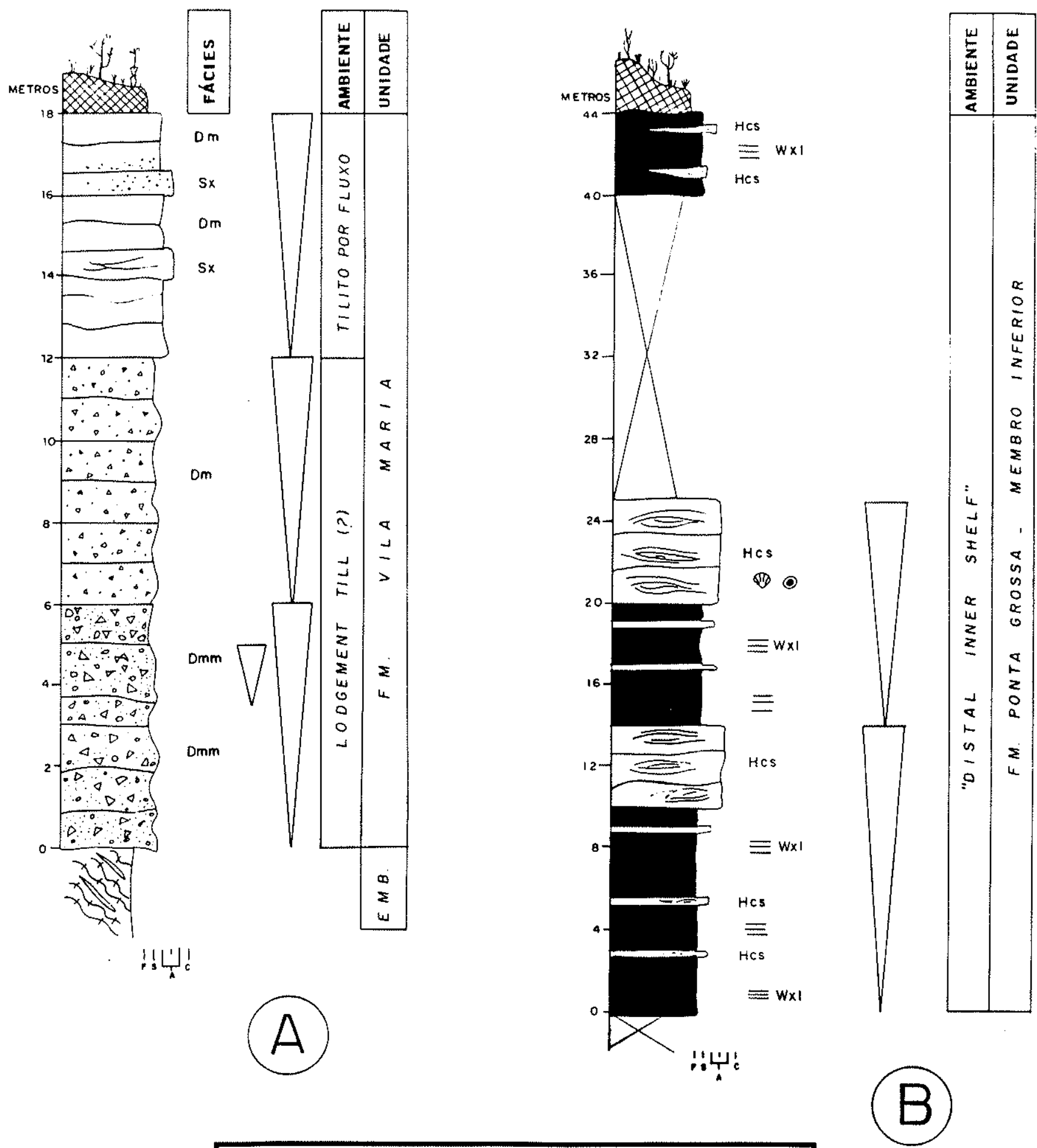

Fig. 16 - Perfis sedimentológicos observados na região do Domo de Araguainha e no municipio de Pedra Branca (MT).

Fig. 16A - Perfil sedimentológico de detalhe realizado na área do Domo de Araguainha $\left(16^{\circ} 48,275^{\prime} S\right.$ e $53^{\circ} 00,058^{\prime} W$ ), envolvendo sedimentos da Formação Vila Maria.

Fig. 16B - Ciclos de engrossamento para o topo observados na parte basal da Formação Ponta Grossa, no município de Pedra Branca $\left(16^{\circ} 37,390^{\prime} S\right.$ e $\left.52^{\circ} 575^{\prime} W\right)$. 
embasamento, onde ocorreriam rochas igneas e metamórficas em cuntato. Aparentemente, esta foi a interpretação utilizada para a elaboração do mapa geológico referente a Folha Goiânia (SE-22) do Projeto Radambrasil (1983). Nesta folha a área central do domo é associada às rochas do Complexo Goiano de idade Arqueana. Entretanto, acreditamos que a análise original de Oliveira (1977) é a mais adequada..

As características apresentadas por Oliveira (1977) para o embasamento metamórfico é idêntica a que observamos no campo, ou seja, o embasamento é composto por filito ardosiano, filito negro e quartzitos. Da mesma forma, o conjunto sedimentar reconhecido por Oliveira (1977) e denominado pelo mesmo como seqüência pré-Furnas foi também observado. Na descrição de Oliveira (1977) esta seqüência é composta predominantemente por arenitos vermelhos de granulação variável de conglomerática a fina, com ampla predominância de arenitos maciços. Ocorrem ainda, secundariamente, siltitos argilosos e conglomerados com matriz síltico-argilosa, de cor vermelho-tijolo escura.

De maneira geral as características sedimentares descritas acima para o conjunto pré-Furnas são idênticas as que observamos nos sedimentos assentados sobre o embasamento metamórfico na área do domo. Este conjunto pode ser associado às fácies de conglomerado e diamictitos da Formação Vila Maria como descritas na região de Barra do Garças. Reforçam esta hipótese (1) ० posicionamento estratigráfico deste conjunto sedimentar entre o embasamento e a Formação Furnas, como observados por nós e por Oliveira (1977), (2) a presença de estruturas de deformação nos sedimentos, colocando os mesmos em uma posição temporal anterior a formação do domo e (3) a caracterização de uma heterogeneidade de fragmentos de rochas do embasamento na composição do diamictito. 
Aparentemente, Assine et al. ('1998b) relatam a existência de diamictitos na região do Domo de Araguainha, entretanto estes autores comentam que em função do grau de deformação é difícil confirmar ou não a existência desses sedimentos. Contudo, a presença de diamictitos e sedimentos correlatos é muito clara, sendo que os mesmos estão assentados diretamente sobre o embasamento. A presença desses diamictitos gera uma incongruência no modelo proposto por estes autores para a região, pois neste trabalho (Assine et al., 1998b), bem como em Assine (1996), é projetada uma grande espessura de sedimentos depositados abaixo dos diamictitos. Este fato só teria justificativa se fosse advogado um controle tectônico na deposição, fato que não é mencionado nos trabalhos. Pelo observado, podemos concluir que na região da estrutura do Domo de Araguainha a seqüência paleozóica da bacia inicia-se por sedimentos associados à Formação Vila Maria, que se depositam diretamente sobre o embasamento metamórfico.

A continuidade do levantamento em direção a cidade de Torixoréu nos possibilitou analisar, em função das boas exposições, a quase totalidade do conjunto sedimentar devoniano registrado nesta região. Nas imediações do município de Pedra Branca (MT) foi possivel caracterizar o conjunto sedimentar associado à parte basal da Formação Ponta Grossa, a partir de uma seção com cerca de 50 metros, composta pelo empilhamento de três afloramentos

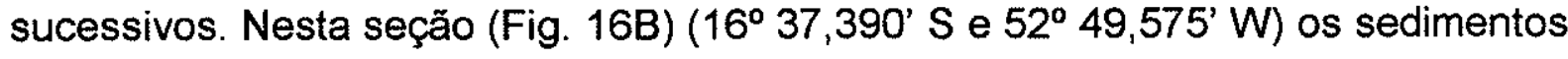
estão empilhados em ciclos de engrossamento para o topo, com aproximadamente 10 metros de espessura. Estes ciclos registram uma nitida tendência de arrazeamento para o topo. Os mesmos são constituídos na base por siltitos e folhelhos com estratificação cruzada por onda, de pequeno porte, e passam progressivamente para arenitos com estratificação cruzada "hummocky". Nestes arenitos são encontrados fósseis representativos da província Malvinocáfrica. Nesta seção fica claramente diagnosticado um arranjo geral transgressivo marcado pela diminuição progressivo da razão areia / argila. Este conjunto sedimentar repousa diretamente sobre a Formação Furnas. 
A relação de contato entre as formações Furnas e Ponta Grossa, nesta área de estudo, é caracterizada por um contato brusco entre os sedimentos arenosos da Formação Furnas e os sedimentos mais finos associados à Formação Ponta Grossa. Na melhor exposição deste contato, localizada a cerca de $4 \mathrm{~km}$ a norté do rio São Domingos ( $16^{\circ} 17,731^{\prime}$ ' S e $52^{\circ} 44,606^{\prime} W$ ), a superfície que marca o limite entre as unidades é interpretada como decorrente do processo transgressivo que afoga os sedimentos costeiros da Formação Furnas. A parte superior desta unidade nesta região é constituída por corpos lenticulares arenosos, de granulometria média a grossa, portadores de estratificação cruzada planar, intercalados por níveis centimétricos de siltito I arenito fino com estratificação cruzada por onda. A base da Formação Ponta Grossa é composta por folhelhos e siltitos apresentando estratificação cruzada por onda. Em termos genéticos não existe nenhuma quebra no registro sedimentar, sendo que a relação de contato marca o afogamento progressivo e pontuado, no contexto de um trato de sistema transgressivo, das fácies proximais por fácies mais distais. Esta situação repete o mesmo evento temporal registrado na região da Serra do Roncador, destacando-se que as diferenças existentes devem-se ao posicionamento paleogeográfico das áreas.

A terceira seção geológica estudada ao longo deste levantamento aflora ao sul da cidade de Torixoréu (MT), ao largo da rodovia (16 $11,656^{\prime} \mathrm{S}$ e $52^{\circ}$ $38,721^{\prime} \mathrm{W}$ ). $\mathrm{Na}$ área ocorre a exposição de um espesso pacote de arenitos finos a médios, de coloração avermelhada. Nestes arenitos a estrutura mais conspicua é a estratificação cruzada do tipo "hummocky", por sua vez o arranjo sedimentar define ciclos de caráter tempestíticos.

Esses sedimentos foram originalmente associados à Formação Aquidauana. Contudo, o posicionamento estratigráfico desse pacote sedimentar, bem como as características sedimentológicas dos mesmos, nos leva a posicionar estes sedimentos no Meso-Devoniano e associá-los ao Membro Médio da 
Formação Ponta Grossa. Sedimentos desta unidade foram descritos por Pereira (1992), na margem direita do Rio Araguaia, nas proximidades da cidade de Baliza (GO) demonstrando assim uma continuidade regional para os mesmos. Em ambas as áreas, este conjunto sedimentar representa a implantação de condições rasas na bacia em um contexto de uma plataforma rasa dominada por ondas de tempestades.

\subsection{3 - Dados de campo obtidos no estado de Goiás}

No estado de Goiás foram revisitados os afloramentos estudados por Pereira (1992) na área abrangendo os municípios de Amorinópolis, Piranhas, e Baliza, como também foram descritos novos afloramentos associados à Formação Vila Maria, localizados na região de Bom Jardim de Goiás.

\subsubsection{1 - Região de Amorinópolis (GO)}

A região de Amorinópolis foi detalhadamente estudada por Pereira (1992). Para esta região, iremos destacar as informações que foram obtidas nesta nova pesquisa e que se referem às características estratigráficas e sedimentológicas do pacote devoniano (Formações Furnas e Ponta Grossa). Os novos dados colhidos corroboram o modelo estratigráfico originalmente proposto para esta área.

No modelo estratigráfico proposto por Pereira (1992), um dos principais pontos de discussão com relação ao pacote sedimentar devoniano é a relação de contato entre as formações Furnas e Ponta Grossa. Esta controvérsia está baseada na observação de dois cortes contínuos ao longo da rodovia GO174 , nas proximidades do trevo de acesso à cidade de Amorinópolis $\left(16^{\circ} 34,697^{\prime}\right.$ $S$ e $51^{\circ} 05,851^{\prime} \mathrm{W}$ ). Nestes afloramentos o limite entre as unidades é definido por 
uma superfície contínua e irregular, localmente erosiva, formada por um nivel de conglomerado (Fig. 17). Para Pereira (1992) esta relação de contato é entendida como representativa de uma superfície transgressiva, no sentido de Nummedal \& Swift (1987), gerada por erosão dos depósitos marinhos rasos durante rápidos aumentos relativos do nivel do mar. Assim, o autor define a passagem entre as unidades Furnas e Ponta Grossa como concordante, onde os estratos analisados foram gerados no contexto de um trato transgressivo.

Como relatado de forma inédita no Capítulo 2.3 , a presença junto à base da Formação Ponta Grossa, mais precisamente a cerca de um metro do contato entre as Formações Furnas e Ponta Grossa, da espécie Ramochitina magnifica, um quitinozoa utilizado como guia do intervalo Praguiano no Gondwana Ocidental e, também, a observação de fragmentos de restos vegetais (Quadros \& Melo, 1986), correlacionáveis ao gênero Cooksonia, de idade Eo-devoniana, em sedimentos finos da Formação Furnas, localizados no topo da unidade, favorecem um arranjo estratigráfico onde a relação entre as unidades é de caráter concordante. Alvarenga et al. (1998), embora não discutam no texto, concordam com o modelo proposto por Pereira (1992). Esses autores admitem, também, que - retrabalhamento transgressivo foi o responsável pela formação dos conglomerados encontrados na base da Formação Ponta Grossa.

$\mathrm{Na}$ região de Amorinópolis há ainda um segundo elemento importante de análise. Ao sul da cidade, na rodovia GO-174, ocorrem excelentes exposições de sedimentos arenosos associados ao Membro Médio da Formação Ponta Grossa. Esses sedimentos, devido as suas características sedimentológicas, foram invariavelmente englobados na Formação Aquidauana. O correto posicionamento estratigráfico destes sedimentos, bem como sua definição informal, foram estabelecidos por Andrade \& Camarço (1980). 


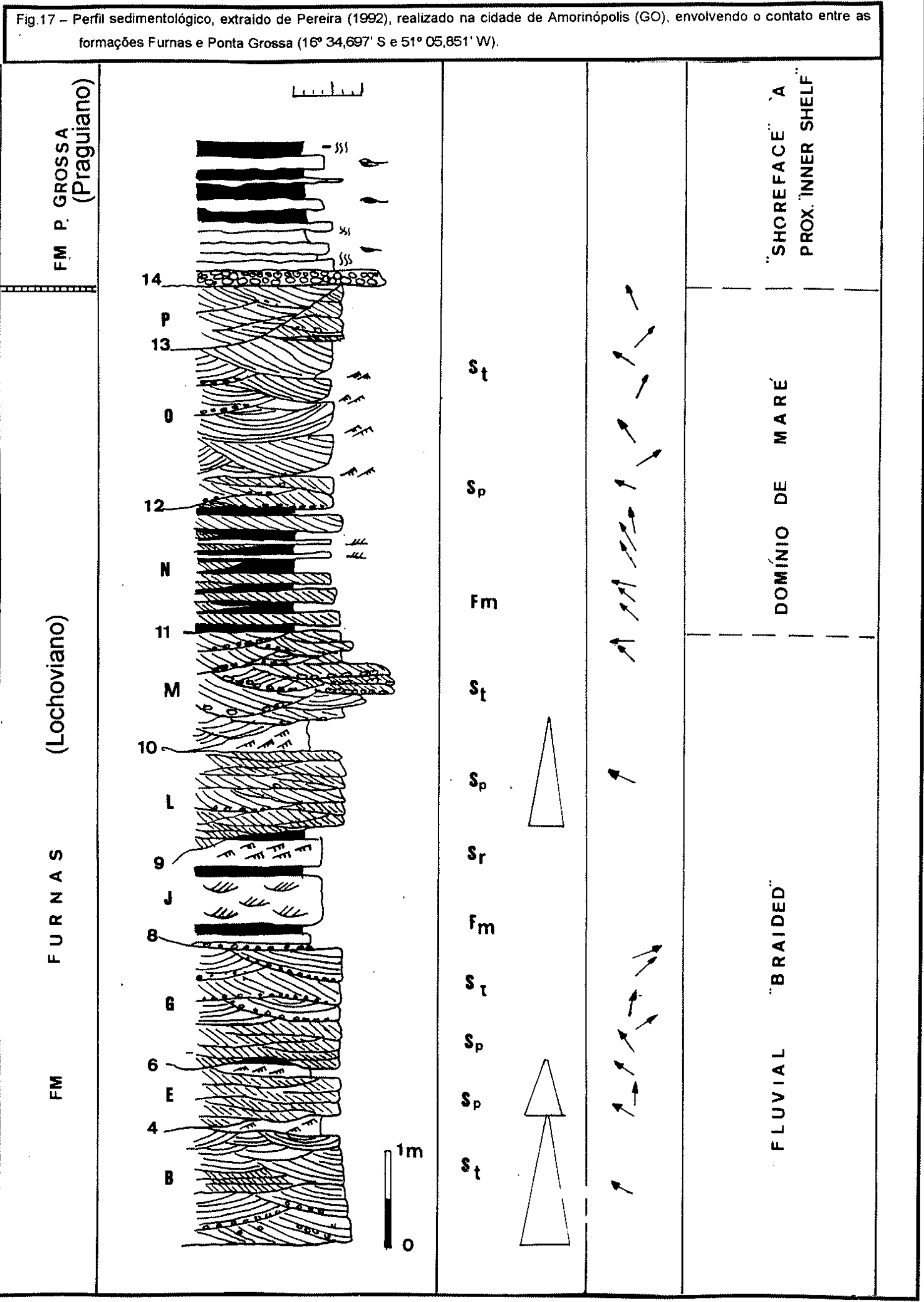


Os afloramentos relativos a este membro, na região de Amorinópolis, foram exaustivamente estudados em termos estratigráficos e sedimentológicos por Pereira (1992). Com base nestes dados, Pereira (1992) define o arranjo sedimentar das rochas analisadas como marcado por ciclos de engrossamento para o topo "coarsening up", limitados por estratificação cruzada por onda. Nos últimos anos, a abertura de novas estradas nesta região permitiu a descrição de novas frentes de exposição de sedimentos associados a esta unidade. Os novos dados obtidos não diferem daqueles apresentados por Pereira $(1992,1994)$ e Pereira et al. (1998). A melhor exposição deste membro ocorre em uma serra ao sul de Amorinópolis (Fig. 18). Esta serra havia sido originalmente descrita por Pereira (1992, fig. 4.22, 6SD-23). Contudo, o novo traçado da rodovia GO-174 permite uma melhor visualização do arranjo sedimentar proposto por Pereira (1992). Nesta mesma localidade, Assine et al. (1998 c) apresentam conclusões exatamente iguais àquelas obtidas por Pereira (1992), embora não as discutam no texto. Entretanto, com relação à seção apresenta por Assine et al. (1998 c), devemos observar que existe um exagero na espessura da unidade. Este exagero pode ser explicado pelo agrupamento de sedimentos da Formação Aquidauana junto ao Membro Médio da Formação Ponta Grossa, bem como por uma provável repetição estratigráfica, em função da presença de falhamentos normais afetando a seção. Esses falhamentos não foram descritos por esses autores, mas são passíveis de observação, como demonstrado no trabalho de Pereira et al. (1998).

Com relação ao intervalo Siluriano, as melhores exposições da Formação Vila Maria, nesta área, ocorrem nas proximidades do vale do Rio Caiapó, na região do Córrego do Brejão. Nesta localidade, as características sedimentológicas da unidade são bastante típicas e foram apresentadas por Pereira (1998). 


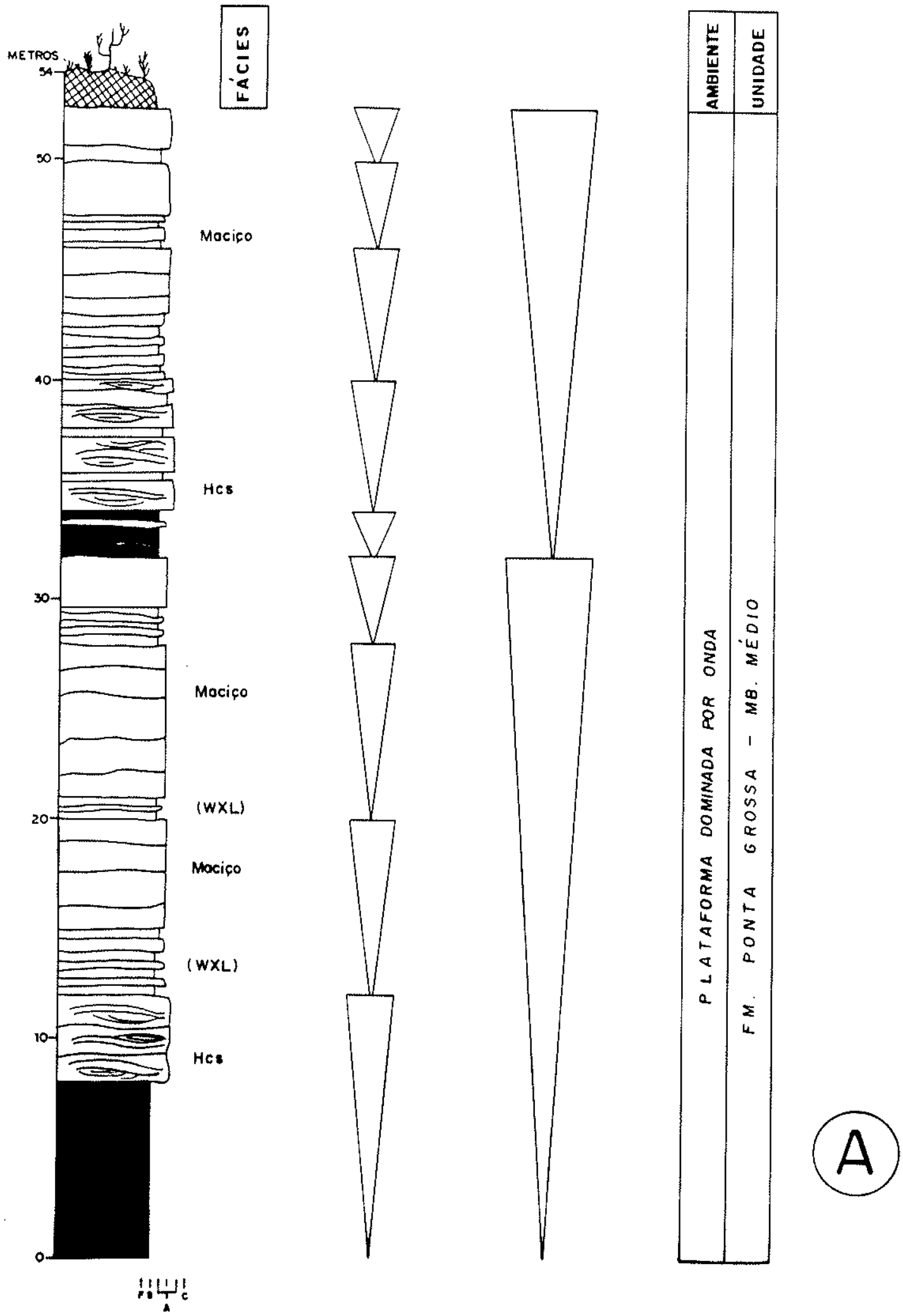

Fig. 18 - Perfil sedimentológico detalhado, realizado ao sul da cidade de Amorinópolis (GO), em um corte de serra da rodovia GO-174, envolvendo os sedimentos do Membro Médio da Formação Ponta Grossa. 


\subsubsection{2 - Região de Piranhas (GO)}

A ampliação da rodovia BR-158, no trecho entre as cidades de Piranhas e Caiapônia, possibilitou uma nova exposição do conjunto sedimentar devoniano. Nesta seção, embora não sejam observadas as relações de contato entre as unidades, foi possivel identificar o empilhamento estratigráfico completo do conjunto devoniano, envolvendo a Formação Furnas e a Formação Ponta Grossa, com seus respectivos membros inferior, médio e superior.

A Formação Furnas apresenta uma excelente exposição no Km 118 da BR-158. A melhor seção aflorante corresponde ao topo da unidade. As características sedimentológicas observadas são bastante similares àquelas analisadas na região próxima à Amorinópolis (GO-174, Km 153). Destacam-se no afloramento não só as litofácies arenosas com estratificação cruzada planar e acanalada, como também a presença de lentes extensas formadas por arenitos finos a muito finos laminados (Fig. $19 \mathrm{~A}$ e B). Não se observa diretamente o limite entre a Formação Furnas e a Formação Ponta Grossa. Contudo, os sedimentos da porção basal desta segunda unidade são constituidos por siltitos e arenitos finos portadores de estratificação cruzada por onda de pequeno porte.

O Membro Médio da Formação Ponta Grossa pode ser observado no $\mathrm{Km} 121$ da rodovia. Neste afloramento destaca-se o arranjo dos sedimentos em ciclos de arrazeamento para o topo, que são progressivamente afogados. Internamente, os ciclos são compostos por arenitos médios a grossos, apresentando estratificação cruzada por onda e estruturas do tipo "wavy" e "linsen" (Fig. 19C). Embora não seja possível definir o limite entre estes sedimentos e os folhelhos e siltitos do Membro Superior da Formação Ponta Grossa, à medida que subimos na estratigrafia observamos um progressivo 


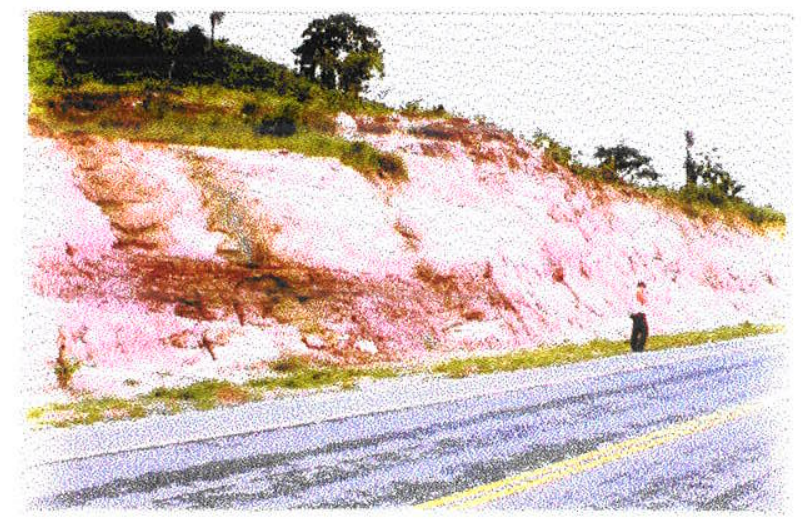

$19 \mathrm{~A}$

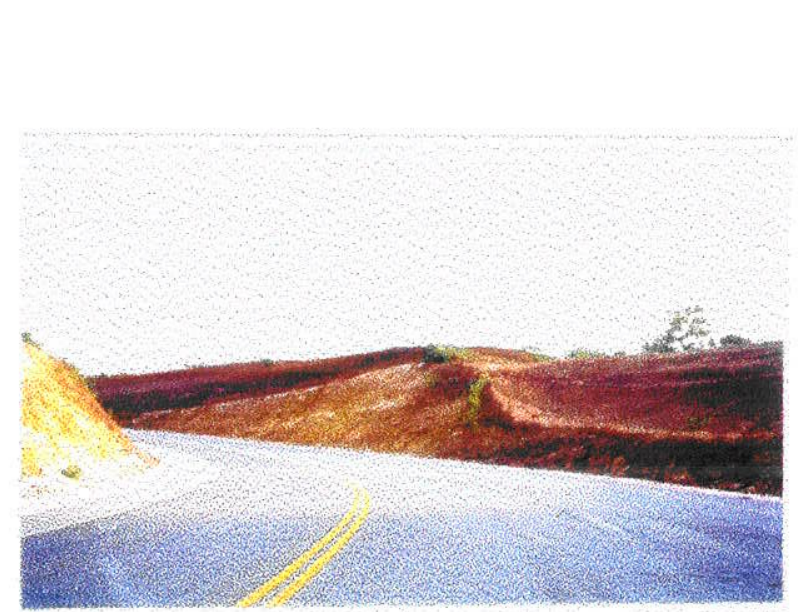

$19 \mathrm{C}$

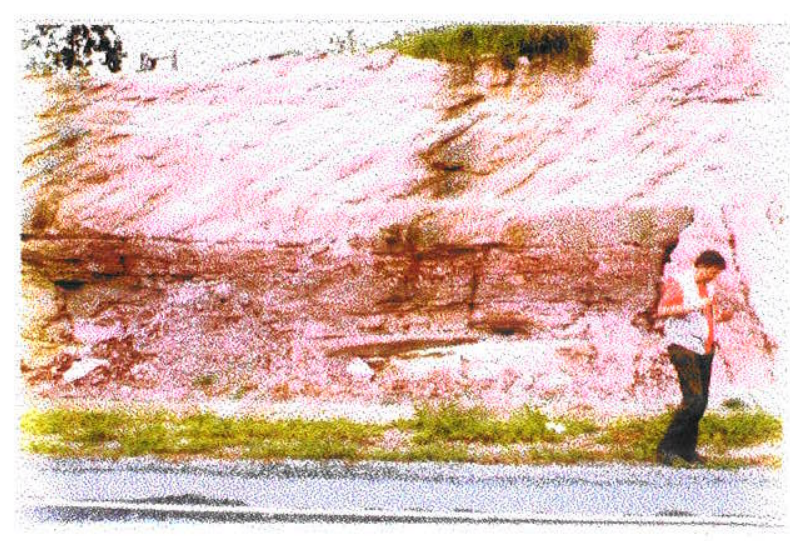

19B

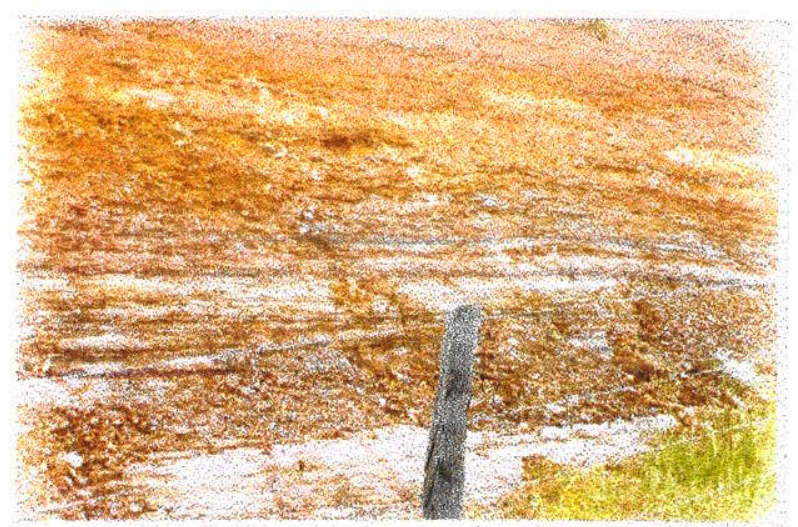

19D

Figura 19 - Aspectos sedimentológicos da seção devoniana, observados na rodovia BR-158, no trecho entre as cidades de Piranhas (GO) e Caiapônia (GO).

A) Aspectos sedimentológicos da Formação Furnas, observados no Km 118 da BR-158;

B) Detalhe dos níveis de arenito fino laminado, observados na foto anterior;

C) Aspectos sedimentológicos da Formação Ponta Grossa (Membro Médio), observados no $\mathrm{Km} 121$ da BR-158;

D) Aspectos sedimentológicos da Formação Ponta Grossa (Membro Superior), observados no Km 149 da BR-158. 
domínio de fácies mais finas, culminando com a deposição de fácies distais representadas por folhelhos ricos em matéria orgânica, que estão muito bem preservados nos afloramentos da rodovia entre os quilômetros 142 e 149 (Fig. 19D). As análises palinológicas realizadas nestes sedimentos confirmam um idade Meso-Devoniaña para os mesmos.

\subsubsection{3 - Região de Baliza (GO) e Bom Jardim de Goiás (GO)}

Nos últimos anos esta região vem sendo palco de trabalhos de investigação geológica, especialmente voltados para o entendimento do contexto estratigráfico dos sedimentos pré-devonianos observados nesta área, em particular no domínio do Ribeirão das Perdizes.

Laranjeiras et al. (1997), Assine et al. (1998a,b) e Alvarenga et al. (1998) relatam a existência de sedimentos pré-devonianos na região do Ribeirão das Perdizes. Tanto Assine et al. (1998a,b) como Alvarenga et al. (1998) identificaram nesta região sedimentos arenosos posicionados estratigraficamente abaixo de diamictitos. Os mesmos foram associados por estes autores à Formação Alto Garças.

Nesta região, destaca-se o afloramento da cachoeira das Perdizes $\left(16^{\circ} 22,11^{\prime} \mathrm{S}\right.$ e $\left.52^{\circ} 22,34^{\prime} \mathrm{W}\right)$, onde estão expostos mais de 80 metros de sedimentos, a partir do embasamento. Nesta seção, Laranjeiras et al. (1997) descrevem uma exposição contínua de sedimentos (Fig. 20A), com cerca de 80 metros, associados à Formação Vila Maria. Em termos sedimentológicos o conjunto foi subdividido em quatro associações de fácies semelhantes àquelas definidas por Pereira (1992). Para Assine et al. (1998a,b) a parte superior do pacote sedimentar exposto na cachoeira estaria associada à Formação Furnas. 

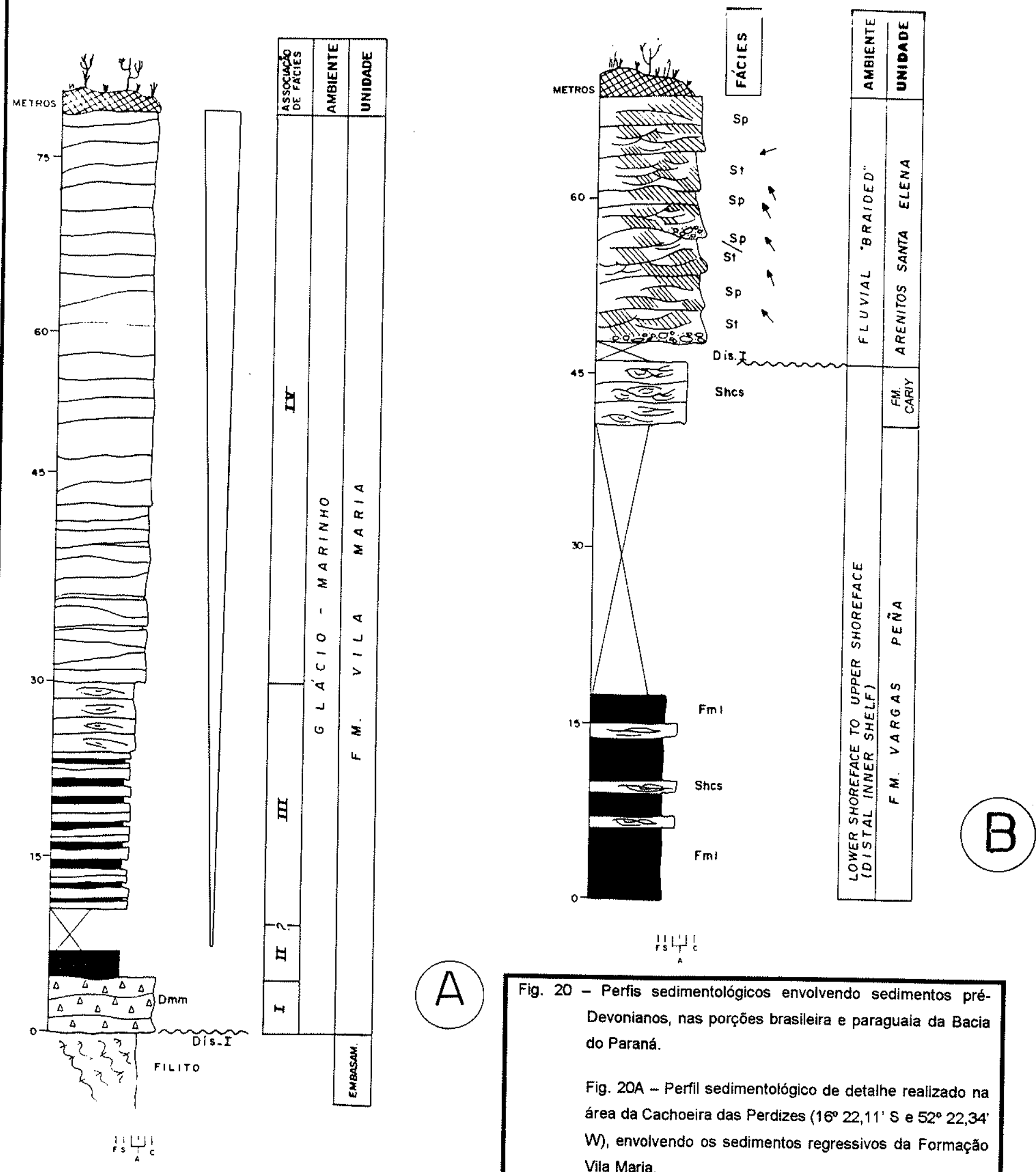

$1 ! 4 ! 5 !$

Fig. 20 - Perfis sedimentológicos envolvendo sedimentos préDevonianos, nas porções brasileira e paraguaia da Bacia do Paraná.

Fig. 20A - Perfil sedimentológico de detalhe realizado na área da Cachoeira das Perdizes $\left(16^{\circ} 22,11^{\prime}\right.$ ' $S$ e $52^{\circ} 22,34^{\prime}$ $W$ ) envolvendo os sedimentos regressivos da Formaçăo Vila Maria.

Fig. $20 \mathrm{~B}$ - Perfil sedimentológico de detalhe realizado na regiāo da cidade de Santa Elena (Paraguai), envolvendo s sedimentos regressivos da Grupo Itacurubí e os - edimentos eodevonianos da Formação Santa Eleıra. 
No entanto, não existe nenhuma evidência de uma quebra na sedimentação ao longo da seção. Na realidade, observa-se um espessamento contínuo das camadas em direção ao topo, e um ligeiro engrossamento ao longo da escarpa. Esta espessura aparentemente anômala da seção arenosa superior da Formação Vila Maria pode ser entendida quando se correlaciona o conjunto sedimentar observado com o Grupo Itacurubí no Paraguai. O contato com a Formação Furnas não é observado diretamente. Acima de uma quebra morfológica presente no relevo da região são descritos arenitos grossos e conglomeráticos que foram atribuídos à base da Formação Furnas. Na Cachoeira das Perdizes a seção sedimentar inicia-se por um pacote de diamictito com cerca de 2 metros de espessura, o qual está depositado diretamente sobre o embasamento, que é constituído por filitos do Grupo Cuiabá. Revisitando esta seção foi possível coletar material palinológico a partir deste diamictito. O material estudado permitiu compreender melhor a relação estratigráfica entre a fácies de diamictito e o folhelho que o recobre. A presença de uma assembléia fossilifera similar, definindo idades próximas, possibilita estabelecer uma direta relação entre o diamictito e o conjunto sedimentar gerado pelo afogamento, que é representado pela fácies de sedimentos finos.

Ainda na região do Ribeirão das Perdizes, próximo à Fazenda Bacuri $\left(16^{\circ} 22,60^{\prime} S\right.$ e $52^{\circ} 24,93^{\prime} \mathrm{W}$ ), foi estabelecido um perfil sedimentológico que também demonstra a intrínseca relação entre os sedimentos finos, gerados em um contexto transgressivo (afogamento), com os sedimentos sotopostos. Neste perfil (Fig. 21A), a sedimentação inicial é marcada por um pacote composto por arenitos com estruturas geradas por escape de fluidos e convolucionamentos. Este pacote é recoberto por lentes arenosas não deformadas de arenitos com estratificação cruzada tabular, que também apresentam icnofósseis do tipo Sckolytus sp. Esse conjunto sedimentar é recoberto por sedimentos finos compostos por folhelhos com estrutura do tipo "wavy/linsen". A correlação entre as seções estabelecidas na área do Ribeirão das Perdizes demonstra uma rápida variação lateral das fácies 
Fig. 21 - Perfis sedimentológicos envolvendo sedimentos da Formação Vila Maria, no sudoeste de Goiás.

Fig. $21 \mathrm{~A}$ - Perfil sedimentológico de detalhe realizado na área da Fazenda Bacuri $\left(16^{\circ} 22,60^{\prime} \mathrm{S}\right.$ e $\left.52^{\circ} 24,93^{\prime} \mathrm{W}\right)$, próximo a Cachoeira das Perdizes.

Fig. $21 \mathrm{~B}$ - Perfil sedimentológico de detalhe realizado na área da Fazenda Fortaleza $\left(16^{\circ} 24,58^{\prime} \mathrm{S}\right.$ e $52^{\circ} 06,60^{\prime}$ W), próximo ao Córrego da Aldeia, municipio de Bom Jardim de Goiás (GO.
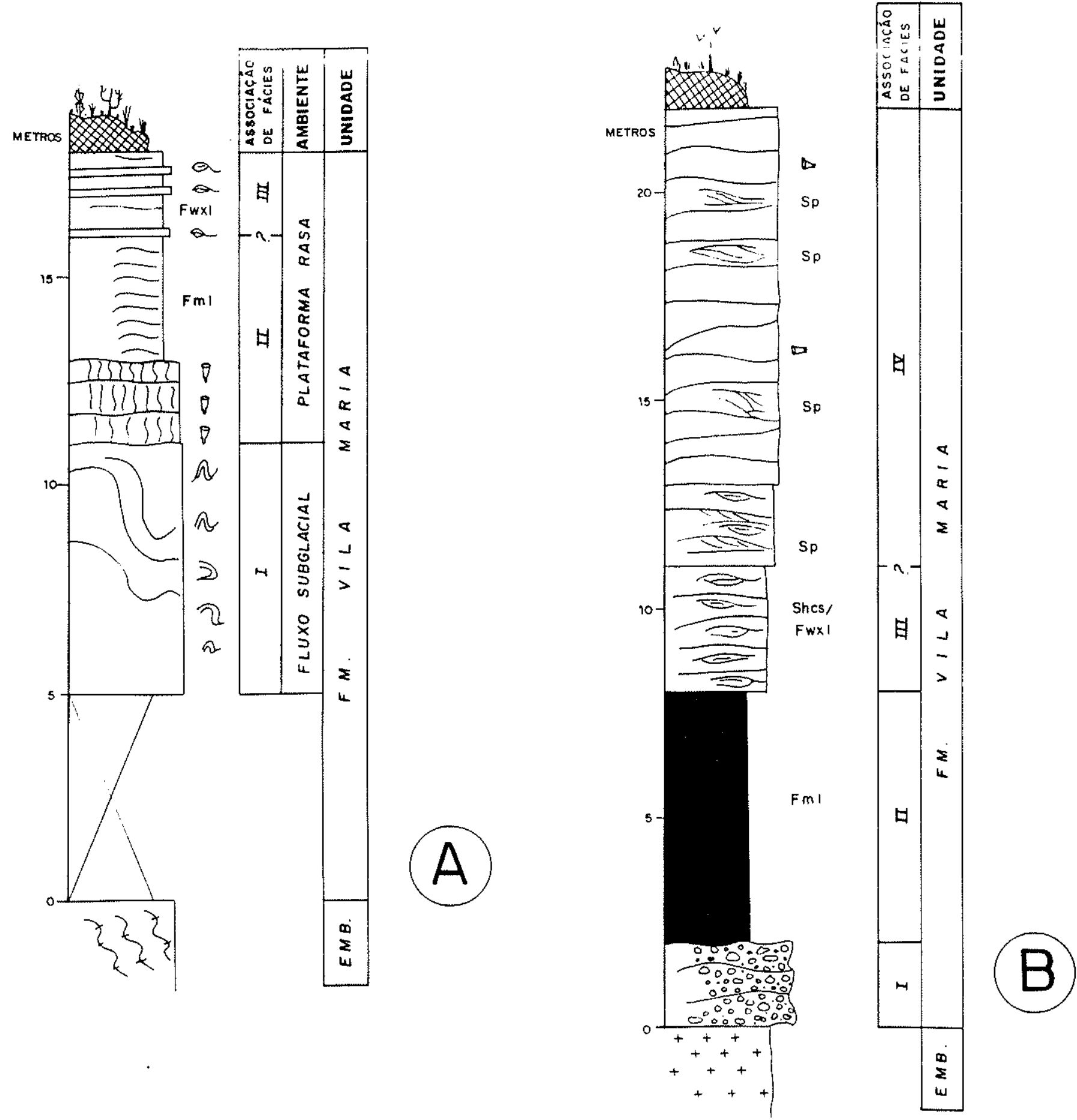
associadas aos sedimentos sotopostos ao folhelho. Esta variação pode estar ligada às mudanças nas características dos fluxos gravitacionais responsáveis pela deposição destes sedimentos, que por sua vez podem estar sendo induzidos por uma dinâmica glacial. Nas duas seções o afogamento é rápido, sendo preservada na Fazenda Bacuri fácies de água rasa na base deste afogamento.

Ainda relacionado aos sedimentos silurianos do sudoeste de Goiás, na região de Bom Jardim de Goiás, próximo a localidade Côrrego da Aldeia, estudada originalmente por Faria (1982), descrevemos uma nova seção sedimentar na Fazenda Fortaleza ( $16^{\circ} 24,58^{\prime}$ S e $52^{\circ} 06,80^{\prime} \mathrm{W}$ ) envolvendo os sedimentos da Formação Vila Maria (Fig. 21B). Nesta seção, sobre o embasamento granítico, está depositado um pacote com cerca de 2 metros de conglomerados organizados que são sucedidos de maneira brusca por folhelhos escuros, nos quais foram observados macrofósseis. A assembléia palinológica presente nestes folhelhos é similar àquelas descritas para este mesmo conjunto sedimentar em outras localidades. Acima desta fácies ocorre um conjunto arenoso que demonstra, nos 15 metros descritos nesta localidade, um contínuo espessamento para o topo, onde as fácies mais características são os arenitos brancos, com geometria sigmoidal e portadores de icnofósseis.

\subsection{4 - Dados de campo obtidos no Paraguai}

Os primeiros trabalhos sobre a geologia do Paraguai remontam ao século dezenove. Contudo, somente na segunda metade do século vinte, iniciaram-se os trabalhos geológicos de caráter mais regional. Como salienta Fúlfaro (1996), até o inicio dos anos oitenta, os trabalhos relacionados à geologia do Paraguai foram realizados exclusivamente com base nos dados de afloramentos. Por sua vez, a maioria dessas publicações relatam informações 
obtidas a partir dos afloramentos existentes na parte central do Paraguai oriental (Fúlfaro, 1996).

As rochas paleozóicas foram estudadas, de forma pioneira, por Harrington (1950). Neste trabalho, o autor descreve dois grupos sedimentares sucessivos para a região oriental do Paraguai, denominados Serie de Caacupé (abaixo) e Série de Itacurubí (acima). Estes nomes foram posteriormente modificados por Harrington (1956) para Grupo Caacupé e Grupo Itacurubi.

A organização estratigráfica proposta por Harrington (1956) e formalizada por este autor em 1972 (Harrington, 1972), de maneira geral, vem sendo utilizada até os dias atuais. Contudo, ao longo de quase meio século de pesquisas várias propostas de modificações foram apresentadas.

Eckel (1959) realizou um detalhado estudo de reconhecimento geológico de todo o território paraguaio. Com relação às rochas do Eopaleozóico, este autor aceita de maneira geral a proposta de Harrington (1950). Todavia, sobre o Grupo Caacupé as interpretações de Eckel (1959) diferem das apresentadas por Harrington (1950), no que se refere: (1) ao posicionamento estratigráfico das localidades fossilíferas denominadas Cerro Aparipí e Pedreira Vargas Peña em Ypacaraí e (2) ao posicionamento estratigráfico da unidade arenítica sacaroidal, no sentido de Eckel (1959) (Formação Tobati; segundo Harrington, 1972). Harrington (1950) acreditava que as duas localidades fossiliferas citadas possuiam uma similar posição estratigráfica, colocadas acima da série arenosa com estratificação cruzada (Arenito Cerro Jhú), mas abaixo da unidade arenítica sacaroidal. Para Eckel (1959) a menos que existissem condicionamentos tectônicos controlando o posicionamento da localidade Cerro Aparipí, a mesma estaria posicionada no topo da série (Grupo Caacupé) e bem acima da unidade sacaroidal. Porém, Eckel (1959) admitia que se o conceito de Harrington sobre um graben na depressão de Ypacarai estivesse correto, as argilas fossiliferas de Ypacarai poderiam estar por baixo da unidade sacaroidal. 
O aspecto controverso referente às localidades fossilíferas foi elucidado por Wolfart (1961, apud Melo, 1985), que teve êxito ao demonstrar que as camadas fossiliferas de Cerro Aparipi e Vargas Peña pertenciam de fato ao Grupo Itacurubi, revelando-se afossilifero o subjacente Grupo Caacupé. De qualquer forma,"o posicionamento estratigráfico dessas camadas abaixo ou acima da unidade sacaroidal não ficou esclarecido.

Em trabalhos mais recentes $\circ$ posicionamento estratigráfico da Formação Tobatí permanece de certa forma em aberto. González et al. (1994), aparentemente, agrupam as unidades arenosas Cerro Jhú e Tobatí, em um único conjunto denominado "Areniscas de Caacupé". $\mathrm{Na}$ interpretação desses autores, no contexto de um ciclo inicial de sedimentação, há um progressivo afinamento para o todo do pacote arenoso, onde ocorreriam arenitos mais puros, melhor selecionados, com aspecto sacaroidal e coloração branca-amarelada. Por outro lado, Orué (1996) afirma, de maneira categórica, que o contato superior da Formação Cerro Jhú é nitidamente discordante com os arenitos de aspecto sacaroide da Formação Tobatí. Orué (1996) afirma ainda que na parte ocidental da Cordilheira de Altos as rochas da Formação Tobatí acham-se superpostas em contato discordante com os arenitos Cerro Jhú. Contudo, Orué (1996) comenta que apesar da Formação Tobatí apresentar razoável extensão na área de seu estudo, o seu contato superior não é observado.

A Formação Tobatí foi formalizada por Harrington (1972). Neste trabalho o autor propõe este nome para substituir a denominação unidade arenítica branca sacaroidal, proposta por Eckel (1959). Para Harrington (1972), a Formação Tobatí (Arenito Tobatí) constitui a parte superior dos "Areniscas de Piribebuy", que para o autor compreende os arenitos Cerro Jhú e Tobatí. Segundo Harrington (1972) a localidade tipo desta formação corresponde às exposições que ocorrem a oeste da rodovia Tobatí para Caacupé, entre 1 e $3 \mathrm{Km}$ ao sul de Tobatí. 
Tanto para Orué (1996) como para González et al. (1994) a Formação Tobatí representa o registro de um conjunto sedimentar inicialmente depositado sob influência fluvial que passa para um ambiente marinho raso, onde podem ser observados icnofósseis associados à icnofácies Skolithos. Contudo, como observamös na área tipo da Formação Tobatí (Fig. 22 - Afl. 7 e Fig. 23A), as características sedimentológicas e deposicionais são bastante distintas das discutidas por esses autores, havendo nesta área o predomínio de estruturas associadas a processos de deformação sin-deposicional como: estruturas de convolução, escape de fluído, e aspecto maciço dos estratos. Subordinadamente, quando podem ser observadas geometrias sigmoídais preservadas, ocorrem estratificação cruzada e climbing ripples, que indicam uma direção de fluxo para noroeste. Esse conjunto de características sedimentológicas pode indicar que a deposição dos sedimentos ocorreu pela interação de fluxos trativos e gravitacionais, no contexto de uma progradação deltaica. Esses aspectos sedimentológicos também podem ser observados em arenitos associados a esta formação no Arroyo Yhacá (Fig. 22 -Afl. 5 e Fig. 23B).

Analisando as descrições originais de Harrignton (1950) fica evidente que a relação estratigráfica entre os arenitos Cerro Jhú e Tobati não foi observada de forma satisfatória pelo autor. O mesmo comenta que somente a parte superior do arenito Tobatí (arenito sacaroidal) está muito bem exposta nas imediações da cidade de Tobatí. Na seção geológica apresentada por Harrington (Fig. 3; Harrington, 1950), a localidade de Tobatí está posicionada no topo de um bloco falhado que compõe o relevo mais alto da região.

Considerando-se os aspectos estratigráficos e sedimentológicos descritos na literatura, e também as observaçōes por nós realizadas, podemos aventar a hipótese de que o pacote sedimentar associado à Formação Tobati, na sua área típica de ocorrência, pertence a uma seqüência deposicional mais jovem, provavelmente Neo-Carbonifera. Esta idade decorre dos dados provenientes do 


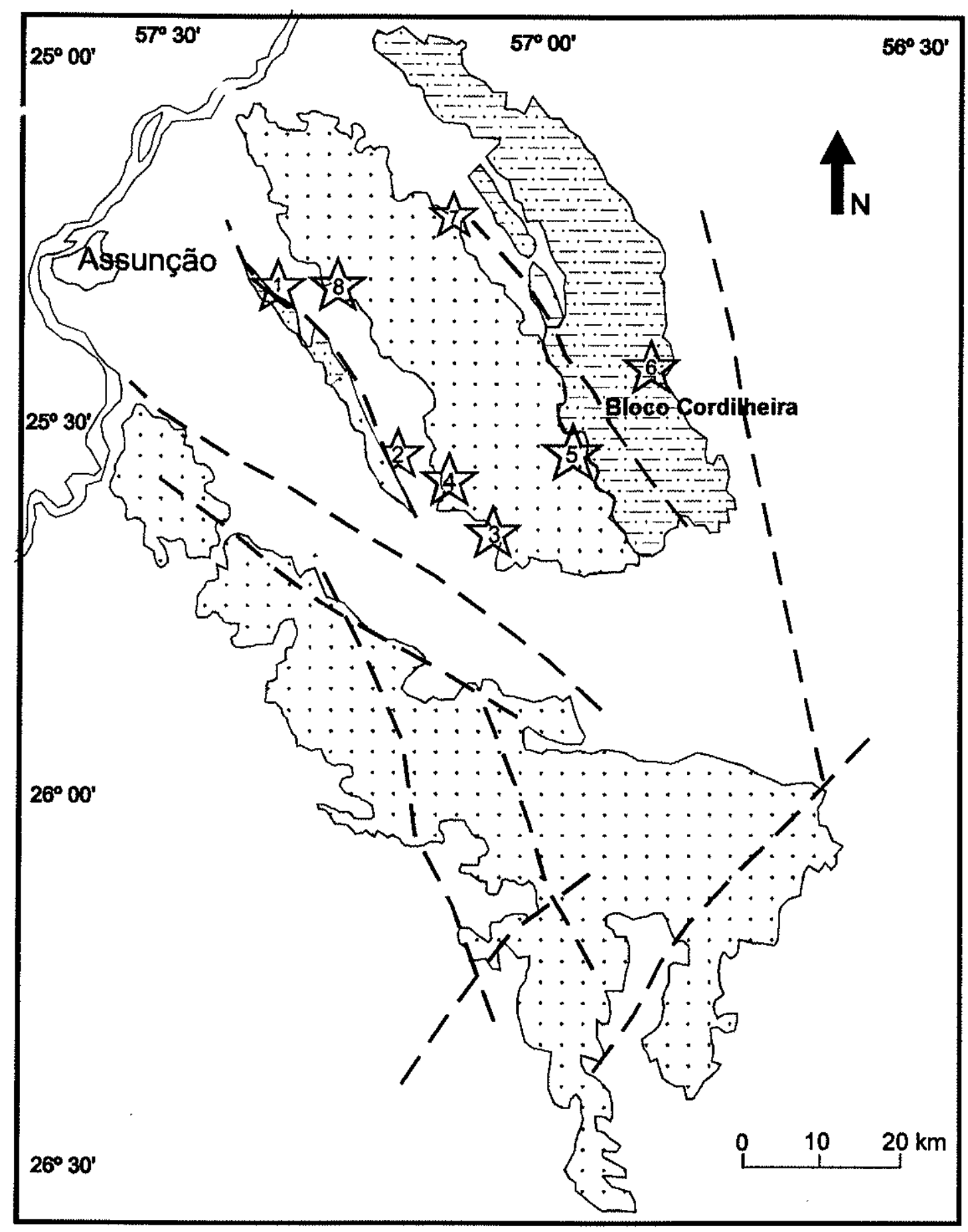

Fig. 22 - Localização dos afloramentos estudados na parte paraguaia da Bacia do Paraná. Base geológica simplificada a partir de González \& Muff (1995).
$=0$ Grupo Itacurubi + Formaçăo Santa Elena
G........ Grupo Caacupé
- Alinhamentos Estruturais
战 Afloramento estudado 
furo de sondagem RD-116, onde foram diagnosticados sedimentos, com idade mínima pós-Frasniana, depositados em discordância sobre sedimentos do EoWenlockiano, sendo que estes sedimentos são ainda sucedidos por sedimentos arenosos grossos com intercalações de níveis argilosos de idade mínima Namuriana. Dessa forma, como se constata neste furo de sondagem, sedimentos grossos de idade no mínimo pós-Frasniana jazem diretamente em discordância sobre sedimentos neo-silurianos. Esta situação pode estar se repetindo, em superfície, na área de ocorrência dos sedimentos silurianos.

O posicionamento estratigráfico do conjunto sedimentar composto pelas formações Paraguari e Cerro Jhú, sobrejacente à Formação Tobatí, é mais consensual na literatura. Após a definição original destas unidades feitas por Harrington (1950), os demais autores que estudaram estes sedimentos (Eckel, 1959; Wolfart, 1961; Putzer, 1962; entre outros) na região central do Paraguai oriental, concordam com a existência de um espesso conjunto arenoso composto na base por conglomerados, que gradam para arenitos estratificados. No entanto, existem dúvidas quanto a espessura desses sedimentos. Os conglomerados Paraguari foram originalmente descritos por Harrington (1950), na localidade de Cerro Jhú. Nesta localidade, segundo Harrington (1972), esses conglomerados podem atingir cerca de 50 metros de espessura. Contudo, como salienta o autor, ao sul da Cordilheira dos Altos (Bloco Cordilheira, segundo Gonzáles et al., 1994) os conglomerados Paraguarí possuem entre 1 e 2 metros de espessura. Esta mesma variação de espessura é admitida por Eckel (1959). Na literatura não existe uma análise explicando se esta variação ocorre de forma lateral ou se há um controle tectônico na distribuição desta litologia.

Tivemos a oportunidade de observar conglomerados associados à Formação Paraguarí em duas localidades (Fig. 22 - Afl. 2 e 4). A primeira está localizada na base da Cordilheira Yaguarón, junto ao limite sudeste do Bloco Assunção, onde foi possivel visualizar o contato entre o embasamento local e o 


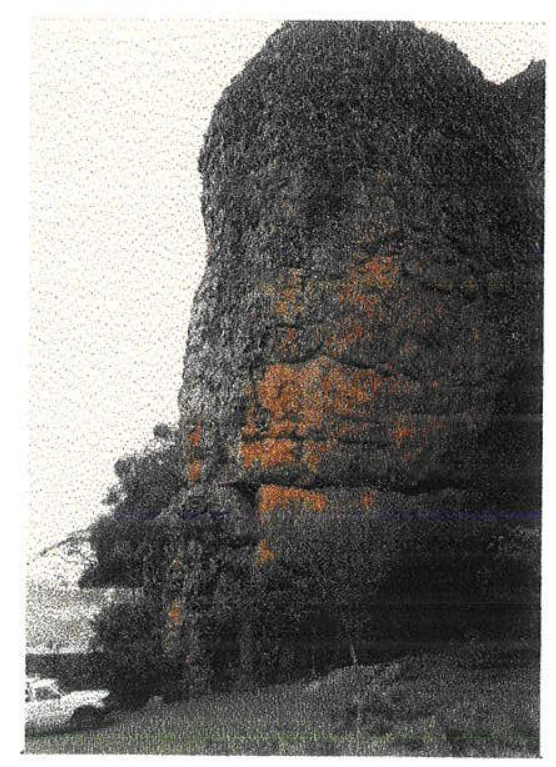

$23 \mathrm{~A}$

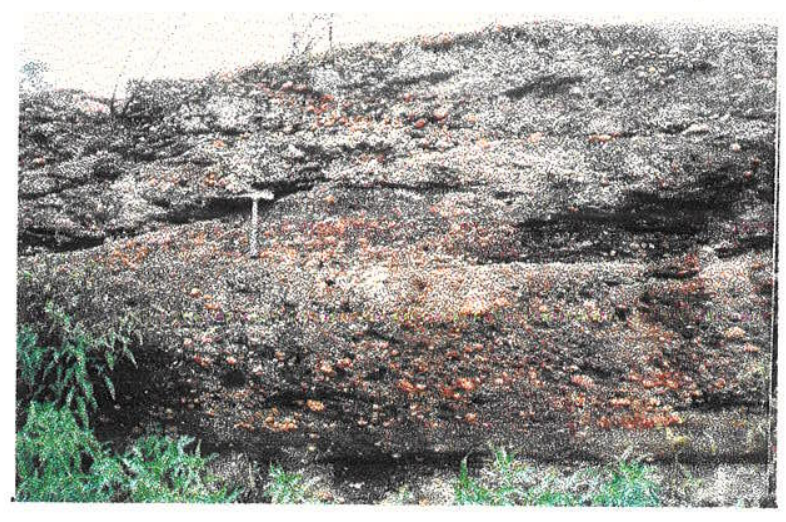

$23 \mathrm{C}$

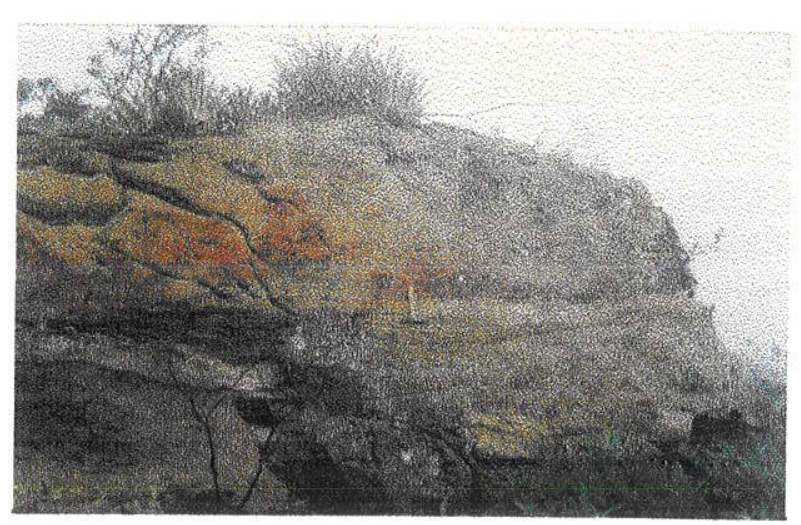

23B

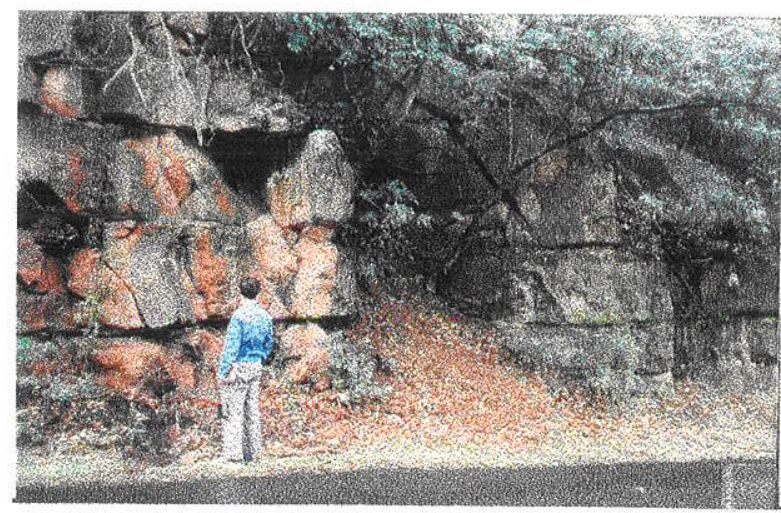

23D

Fig. 23 - Aspectos sedimentológicos do Grupo Caacupé, observados no domínio do Bloco Cordilheira, na República do Paraguai.

A - Depósitos da Formação Tobatí, observados em afloramentos na localidade de $\mathrm{n}^{0} .7$ (Fig. 22)

B - Depósitos da Formação Tobatí, observados em afloramentos na localidade de $n^{\circ} .5$ (Fig. 22)

C - Depósitos do conglomerado Paraguarí, observados em afloramentos na localidade de $\mathrm{n}^{\circ} 4$ (Fig. 22)

D - Depósitos da Formação Cerro Jhú, observados em afloramentos nas localidades de $n^{0} 3$ e 4 (Fig. 22) 
conglomerado Paraguarí. Neste local, o conglomerado, mal preservado, caracteriza-se pelo predomínio de quartzo de veios e quartzito arredondados, esféricos a alongados, envoltos por um matriz predominantemente arenosa. $O$ conglomerado é de maneira geral desorganizado, podendo ocorrer, localizadamente, arranjo gradacional inverso dos seixos e intercalações de arenitos conglomeráticos.

A segunda localidade visitada está situada na porção sudoeste do Bloco Cordilheira na base da Cordilheira dos Altos. Com base nos afloramento isolados descritos ao longo da estrada que liga Paraguarí a Ruta 1 (Fig. 22 - Afl. 4), observa-se uma aparente gradação entre um conglomerado basal menos organizado, com raros seixos imbricados que indicam uma paleocorrente em direção à sudoeste, para um pacote conglomerático organizado portador de estratificação cruzada e com intercalações de arenitos conglomeráticos. 0 conglomerado mais organizado apresenta seixos achatados a pouco esféricos $e$ arredondados. O mesmo é suportado por clastos, os quais são essencialmente quartzosos, ocorrendo subordinadamente matriz arenosa. Os seixos estão aparentemente imbricados para sul/sudeste. Ocorrem ainda estratificação cruzada planar e acanalada, as quais indicam uma direção pretérita de fluxo para sudoeste. Não há indicação de basculamento tectônico afetando os afloramentos observados. Nas porções mais organizadas ocorrem ciclos de gradação normal de poucos metros, composto por um conglomerado na base e arenitos grossos no topo (Fig. 23C). O arranjo de fácies observado nas duas localidades possibilita interpretar que a deposição desses sedimentos ocorreu no contexto de um leque proximal (senso Collinson, 1986). Porém, a presença de seixos achatados no conglomerado observado na segunda localidade e a ausência dos mesmos na primeira podem indicar diferente posicionamento relativo das localidades em relação a uma linha de costa pretérita. 
$\mathrm{Na}$ literatura descreve-se que em sucessão aos conglumerados Paraguarí ocorrem os arenitos Cerro Jhú. Nas duas localidades visitadas referentes ao conglomerado Paraguari, não observamos diretamente esta passagem. Contudo, na localidade situada junto a porção sudoeste do Bloco Cordilheira, na mesma seção dos conglomerados, pouca dezenas de metros à frente, subindo a Corditheira dos Altos, afloram em um novo corte, um pacote sedimentar predominantemente arenoso associado à Formação Cerro Jhú (Fig. 22 - Afl. 3 e 4). Os corpos arenosos são essencialmente tabulares e contínuos. Os corpos organizam-se internamente em ciclos de granodecrescência ascendente, formados na base por níveis conglomeráticos, por vezes erosivos. Os corpos tabulares são, normalmente, delimitados no topo por delgadas camadas de areia fina / silte, não sendo observado retrabalhamento por onda (Fig. 23D). Subindo na estratigrafia, ocorrem corpos arenosos de granulometria média com estratificação cruzada de baixo ângulo, associados à níveis arenosos tabulares com laminação plano-paralela a levemente truncadas, nos quais são observados traços fósseis associados aos icnogêneros Rusophycus e Cruziana.

Acima do horizonte rico em icnofósseis, fechando a seção aflorante, estão expostos estratos arenosos médios a grossos, portadores de estratificação cruzada tabular de grande porte e com alto ângulo. Nas lâminas cruzadas são observadas estruturas do tipo "grain fall" e "grain flow", denotando retrabalhamento eólico dos sedimentos. O arranjo sedimentar observado na base da seção Cerro Jhú indica que a deposição ocorreu em um contexto costeiro, através da interação entre sistemas deposicionais do tipo "braid delta" e de praia.

Arenitos associados à porção intermediária da Formação Cerro Jhú afloram em um grande corte da rodovia que liga Assunção a Caacupé (Fig. 22 Afl. 8). Este afloramento está posicionado na borda oeste do Bloco Cordilheira, na Cordilheira dos Altos, próximo ao lago de Ypacaraí. Neste afloramento são observados corpos arenosos contínuos com geometria tabular a sigmoidal, imbricados e limitados por niveis argilosos, com uma indicação de fluxo para sul. 
Observa-se na base desses corpos estruturas de carga, como também corpos arenosos fluidizados. O conjunto sedimentar observado neste corte é similar ao pacote arenoso sobrejacente aos depósitos de praia descritos na seção anterior. Assim, provavelmente, a sedimentação também ocorreu em um sistema do tipo "braid delta". Entretanto, o predomínio dos depósitos sigmoídais amalgamados, de grande extensằo, limitados por superfícies contínuas, descritos neste afloramento, indica que a deposição ocorreu em posições mais distais em relação ao sítio deposicional definido para a seção mais basal da Formação Cerro Jhú.

Em função da inexistência de fósseis nos sedimentos associados ao conjunto Paraguarí e Cerro Jhú, a idade de sedimentação do mesmo tem que ser inferida pelo seu posicionamento estratigráfico. Como visto, os sedimentos do Grupo Caacupé são sucedidos pelo Grupo Itacurubí (Harrington, 1950), sendo que este último foi originalmente definido por Harrington (1950) como de idade Devonina. Esta idade Devoniana foi mantida por Harrington (1956) e por Eckel (1959). Todavia, como salienta Harrington (1972), Wolfart publicou em 1961 um artigo sobre a estratigrafia e paleontologia do Paraguai, onde o autor (Wofart, 1961) prova que os sedimentos do Grupo Itacurubí expostos a leste da cidade de Eusébio Ayala, até então imaginados como de idade Devoniana, eram em verdade de idade Eo-Siluriana. Neste mesmo trabalho Wolfart (1961) demonstrou que as localidades fossiliferas Cerro Aparipí e Vargas Peña, como já visto, pertenciam ao Grupo Itacurubí, mantendo, no entanto, a idade Siluriana proposta originalmente por Harrington (1950) para as mesmas.

O Grupo Itacurubí foi formalmente definido por Harrington (1972) com base nos seus trabalhos de 1950 e 1956. Segundo Harrington (1972), este grupo está distribuído em afloramentos isolados e descontínuos, formando um cinturão de exposição com mais de $85 \mathrm{Km}$ de extensão, na direção N-NW e S-SW, entre Arroyos y Esteros e San José, e $20 \mathrm{Km}$ de largura entre Eusébio Ayala e Santa Elena. O mesmo é composto, da base para o topo, pelas seguintes formações: Euzébio Ayala, Vargas Peña e Cariy. 
A organização estratigráfica do Grupo Itacurubí, como proposta por Harrington (1972), vem sendo mantida pela maioria dos autores que se ocuparam destes sedimentos. Uma tentativa de modificação foi sugerida por Orué et al. (1992; apud Orué, 1996). Estes autores propuseram a redefinição da Formação Euzébio Ayala, englobando na mesma os sedimentos das formações Vargas Peña e Cariy e a introdução das formações Boquerón e Isla Pucú, respectivamente, como a unidade inferior e superior do Grupo Itacurubí. Os argumentos listados por Orué (1996) justificando as modificações para a Formação Euzébio Ayala são todos de caráter genético. O autor argumenta, corretamente, que existe uma continuidade deposicional entre as formações que compõem o grupo. Este aspecto, contudo, não inviabiliza a individualização das unidades, que são passiveis de reconhecimento no campo em função das características sedimentológicas algo distintas e pelo posicionamento estratigráfico das mesmas. No entanto, uma simplificação de nomenclatura, à luz da estratigrafia genética, poderia ter lugar através da consideração do Grupo Itacurubí como indiviso.

As duas unidades estratigráficas introduzidas por Orué et al. (1992; apud Orué, 1996), formações Boquerón e Isla Pucú, não são aqui consideradas. A primeira, embora não tenha sido por nós reconhecida no campo é de ocorrência muito limitada, como ressaltado por Orué (1996), podendo assim representar uma fácies mais específica da porção basal do Grupo Itacurubí. A segunda unidade, Formação Isla Pucú, é definida pelo autor como sobreposta em discordância, tanto em superfície como em subsuperfície, aos sedimentos da Formação Euzébio Ayala. No entanto, como veremos, o registro bioestratigráfico para o furo RD-116 não demonstra, para $\circ$ intervalo assinalado pelo autor, nenhuma quebra estratigráfica significativa. Em verdade, nesta posição ocorrem sedimentos marinhos de plataforma associados à transgressão Llandoveriana.

As rochas do Grupo Itacurubi representam um grande ciclo transgressivo-regressivo. Este ciclo é formado na base por arenitos e siltitos 
associados a Formação Euzébio Ayala. As rochas desta unidade são formadas por arenitos finos a médios, micáceos, com abundante estratificação cruzadas por onda (Fig. 22 - Afl. 1) Os estratos arenosos organizam-se em conjuntos marcados pelo engrossamento e espessamento para 0 topo. Os estratos individualmente apresentam geomentria sigmoidal e feições de compensação de camadas. Os estratos, decimétricos, representam ciclos tempestíticos marcados na base por estrutura de sola e finalizados por níveis de ondas truncados (Fig. 24A). É comum a presença de níveis ricos em clastos de argila, milimétricos a centimétricos, por vezes alinhados nas cristas das ondulações. Na superfície das ondas são observados icnofósseis em abundância, sendo bem caracterizado os icnogêneros Cruziana e Skolithos. Ocorrem ainda niveis finos com estruturas do tipo "wavy / linsen" característicos de depósitos originados por tempestitos distais.

Os sedimentos associados à Formação Euzébio Ayala assentam-se diretamente sobre o Grupo Caacupé. Aparentemente, o contato entre estas unidades pode ser descrito em uma Pedreira próximo a cidade de Euzébio Ayala. Nesta localidade, ocorre um nítido limite, interpretado como uma superfície transgressiva, marcado pela deposição de siltitos / folhelhos com "wavy / linsen" sobre fácies arenosas sacaroidal. Na pedreira os pacotes arenosos apresentamse na forma de sigmóides imbricadas, limitadas por niveis arenosos finos laminados. Os aspectos sedimentológicos do conjunto arenoso subjacente aos sedimentos finos da Formação Euzébio Ayala, nesta localidade, assemelham-se aos diagnosticados para a Formação Cerro Jhú. Contudo, não existem claras evidências para afastar a possibilidade de que o limite analisado esteja inserido na Formação Euzébio Ayala, como ocorre no furo de sondagem RD-115.

Na literatura é advogada uma associação genética entre as rochas da parte superior do Grupo Caacupé e a Formação Euzébio Ayala. Estas rochas seriam geradas dentro de um contexto transgressivo, onde progressivamente depósitos de plataforma rasa sobrepõem aos depósitos costeiros do Grupo Caacupé. A continuidade desta transgressão culmina com os folhelhos e siltitos da 


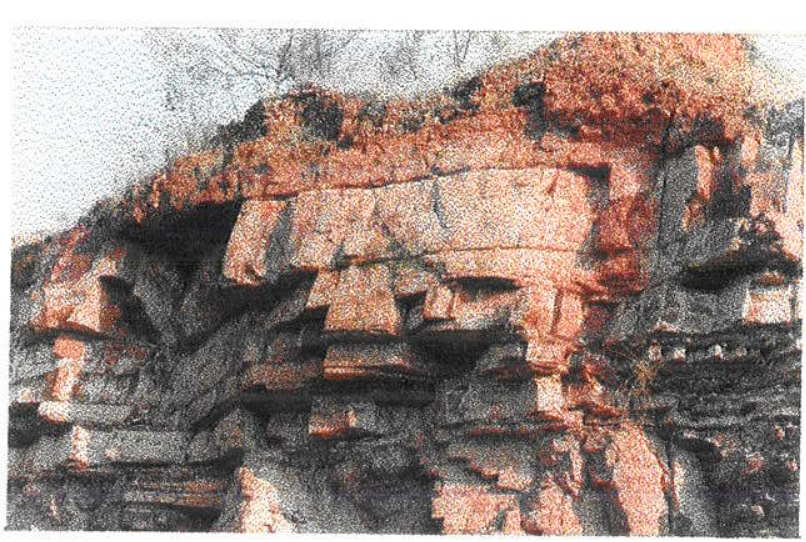

$24 \mathrm{~A}$

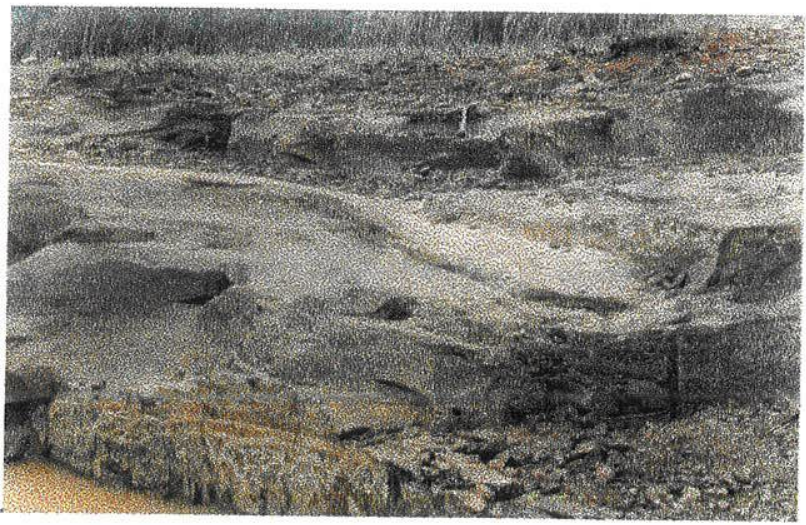

$24 \mathrm{C}$

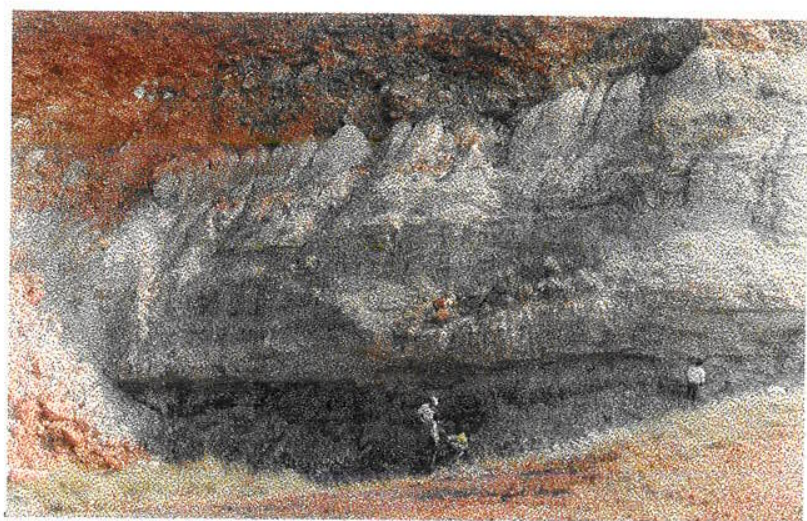

24B

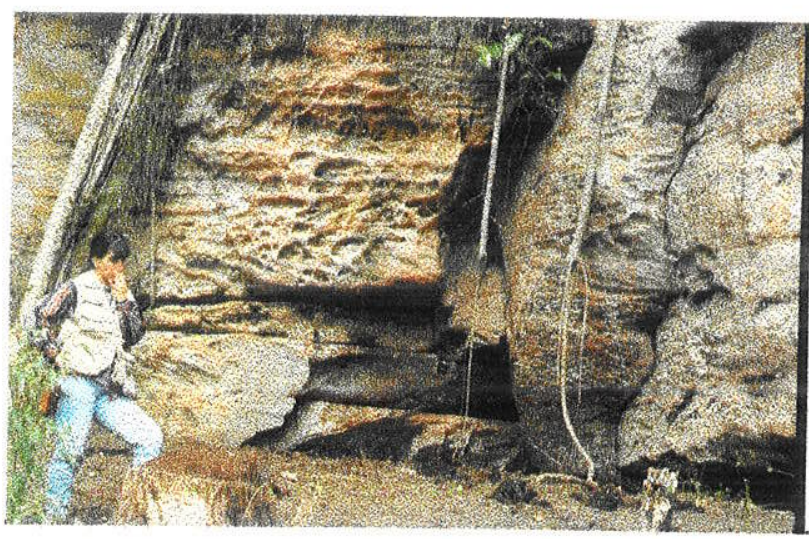

24D

Fig. 24 - Aspectos sedimentológicos do Grupo Itacurubí, observados no domínio do Bloco Cordilheira, na República do Paraguai.

A - Depósitos da Formação Euzébio Ayala, observados em afloramentos na localidade de $\mathrm{n}^{0} 1$ (Fig. 22)

B - Depósitos da Formação Varga Peña, observados em afloramentos na localidade de $n^{\circ} .1$ (Fig. 22)

C - Depósitos da Formação Carriy, observados em afloramentos na localidade de $n^{\circ} .6$ (Fig. 22)

D - Depósitos da Formação Santa Elena, observados em afloramentos na localidade de $\mathrm{n}^{\circ} .6$ (Fig. 22) 
Formação Vargas Peña. Esta unidade constitui a porção mais argilosa do Grupo Itacurubí.

A Formação Vargas Peña, segundo a definição de Harrington (1972), possui cerca de 20 metros de espessura, sendo a mesma composta exclusivamente de folhelhos alterados (Fig. 24B). Esta espessura é a mesma descrita por Wood \& Miller (1997) na localidade tipo desta formação, onde a mesma está limitada pelas formações Euzébio Ayala e Cariy (Fig. 22 -Afl. 1). Analisando-se os furos de sondagem observa-se um expressivo espessamento desta formação, que pode atingir até 70 metros no furo RD-116 (Fig. 32), considerando somente os folhelhos. Contudo, se analisarmos esta unidade com base na relação genética das fácies de folhelhos e arenitos, e na idade de deposição, observaremos que o conjunto sedimentar Llandoveriano pode atingir até 250 metros.

O fechamento do Grupo Itacurubi é marcado pela deposição dos arenitos da Formação Cariy (Fig. 22. - Afl. 6). Esta unidade foi formalizada por Harrignton (1972) para designar um conjunto sedimentar com cerca de 100 metros de espessura formado, predominantemente, por arenitos amarelados com intercalações de folhelhos, sobreposto à Formação Vargas Peña. Nas localidades visitadas (Arroyo Yhaguy e Região de Santa Elena) esta unidade é caracterizada por arenitos finos a médios, bem selecionados, com abundante presença de estruturas hummocky (Fig. 24C). Os arenitos estão organizados em pacotes centimétricos, sendo comum a presença de fósseis e clastos de argila na base dos mesmos, definindo ciclos de tempestades. Ocorrem também pacotes arenosos mais homogêneos, métricos, sem estrutura interna visível, envelopados por niveis finos, sendo o topo dos mesmos normalmente retrabalhado por ondas, representando depósitos de sandwaves retrabalhado por ondas. 
Nas duas localidades não se observa diretamente a relação entre estes arenitos e os sedimentos subjacentes da Formação Vargas Peña. $\mathrm{Na}$ área de Santa Elena, os folhelhos desta última formação apresentam um aumento na razão areia/silte em direção ao topo, ocorrendo uma progressiva intensificação de estratos arenosos com hummocky intercalados aos folhelhos. Este mesmo arranjo para o Vargas Peña pode ser observado de forma sutil no furo RD-116 e na área tipo de ocorrência desta unidade. No caso da localidade tipo, este aumento de estratos arenosos é associado à Formação Cariy, embora os aspectos sedimentológicos sejam distintos. Ainda na região da localidade tipo, os sedimentos que melhor seriam comparáveis à Formação Cariy são, no entanto, cartografados como pertencentes à Formação Euzébio Ayala.

Apesar dos aspectos contraditórios, a Formação Cariy representa o fechamento de um ciclo transgressivo-regressivo de idade Llandoveriana. Seus depósitos são correlacionáveis à Associação de Fácies IV descrita por Pereira (1998) para a Formação Vila Maria. Esta correlação também é admitida por Milani (1997). Este autor correlacionou à Formação Cariy a uma sucessão progradante acima dos pelitos Vila Maria, identificada por Pereira et al. (1995b) no extremo noroeste da Bacia do Paraná, admitindo que a mesma deveria corresponder à seção que sucede aos folhelhos Vargas Peña no poço Asunción - 1 .

Assim, como sugere Borghi et al. (1997) a "sucessão estratigráfica registrada no Grupo Itacurubí parece ser correlacionável àquela da Formação Vila Maria, mostrando uma grande similaridade de sistemas deposicionais e uma sincroneidade de eventos deposicionais". Esta similaridade evolutiva é reforçada pela identificação nos depósitos associados à Formação Vila Maria, como discutido anteriormente, de um expressivo conjunto sedimentar arenoso, glacialmente influenciado, subjacente aos diamictitos desta unidade e, também, pela caracterização de um espessamento da seção regressiva acima dos folhelhos e siltitos da Formação Vila Maria em direção a oeste, como observado na região de Baliza (GO). 
A identificação de sedimentos devonianos na região central do Paraguai oriental, correlacionáveis às formações Furnas e Ponta Grossa, permanece ainda como uma questão polêmica. Como salienta Fúlfaro (1996) a realização de perfurações no início dos anos oitenta, permitiu esta identificação. Milani \& Daemön (1992), a partir de uma análise bio-litoestratigráfica dos poços Asunción - 1 e Asunción - 2, redefiniram a distribuição dos sedimentos devonianos nesses poços. Ainda segundo Fúlfaro (1996), estes sedimentos estariam atualmente preservados em blocos baixos em subsuperfície.

Segundo Harrington (1972), com base nos estudos realizados até aquele momento, não existiam evidências de exposição de rochas devonianas expostas no Paraguai Oriental. No entanto, recentemente, Gonzáles et al. (1994) descreveram um conjunto sedimentar arenoso sobreposto, em discordância, aos sedimentos silurianos do Grupo Itacurubi e subjacentes a sedimentos carboniferos, ao qual atribuíram uma idade Neo-Siluriana - Eo-Devoniana. Este conjunto sedimentar informalmente denominado Formação Santa Elena é composto por arenitos médios a grossos, com estratificação cruzada e conglomerados.

Em um segundo trabalho, Gonzáles \& Muff (1995) formalizaram a ocorrência da unidade Santa Elena. Segundo os autores, a mesma aflora como uma franja NW/SE desde o rio Paraguai até o povoado homônimo (Fig. 22 - Afl. 6). Neste trabalho, os autores argumentam que as investigações de campo identificavam uma idade devoniana para a unidade Santa Elena, porém, como ressaltado pelos mesmos, uma análise detalhada de poços levou a colocação destes sedimentos no Grupo Itacurubí.

Os sedimentos da Formação Santa Elena foram visitados na região de sua localidade tipo nas proximidades do povoado de mesmo nome e na região de Isla Pucú. Estes sedimentos são compostos por arenitos grossos e 
conglomerados. Os estratos estão organizados em ciclos de afinamento para o topo, iniciados por conglomerados. Os arenitos apresentam abundante estratificação cruzada planar e, subordinadamente, estratificação cruzada acanalada (Fig. 24D). As direções de paleocorrentes indicam uma migração das formas de leito para noroeste. Os estratos são métricos, com geometria lenticular. As relações entre os estratos são normalmente erosivas. Excepcionalmente, os estratos atingem mais de um metro de espessura, sendo composto por arenitos com estratificação cruzada de grande porte. $O$ arranjo sedimentar observado conduz a interpretação de que os sedimentos foram depositados a partir da migração de dunas subaquosas em um sistema fluvial de alta energia (fluvial entrelaçado).

Em uma seção levantada próximo ao povoado de Santa Elena, estes arenitos estão em contato com sedimentos associados à Formação Cariy (Fig. 20B). Este contato é de caráter brusco e discordante. Os sedimentos da Formação Cariy, nesta localidade, são caracterizados por arenitos finos a médios com abundante estratificação cruzada por onda. Sobrepondo-se a estes, de forma brusca, observam-se os conglomerados e arenitos grossos da base da Formação Santa Elena. A relação de contato entre estas unidades assemelha-se ao contato entre as formações Vila Maria e Furnas na bacia. O limite entre estas duas últimas unidades é normalmente marcado por um limite brusco e erosivo, que coloca em contato camadas de arenitos finos a médio da porção regressiva da Formação Vila Maria, com corpos lenticulares a tabulares de conglomerado, pertencentes à base da Formação Furnas. Assim, a Formação Santa Elena por suas características sedimentológicas e posição estratigráfica, deve corresponder à parte basal da Formaçäo Furnas.

Dessa forma, ao contrário do que foi proposto por Gonzáles \& Muff (1995), os sedimentos da Formação Santa Elena não devem ser posicionados no Grupo Itacurubí, mas considerados como o registro de um novo evento deposicional pós-Llandoveriano, concepção originalmente proposta por Gonzáles 
et al. (1994). A idade desses sedimentos é de difícil precisão. A correlação estabelecida por Gonzáles \& Muff (1995) no furo RD-116 está equivocada. Parte dos sedimentos admitidos por estes autores como pertencentes à Formação Santa Elena estão associados à conglomerados e diamictitos de idade minima Namuriana. No entanto, no intervalo entre 150 e 99 metros deste furo (Fig. 32), ocorre um pacote sedimentar composto de arenitos e conglomerados, datado de Eo-Wenlockiano no seu topo. A natureza desses sedimentos os diferencia, em parte, daqueles descritos para a Formação Cariy. Poderia ser aventada a correlação deste intervalo arenoso aos sedimentos da Formação Santa Elena. Entretanto, as características sedimentológicas são parcialmente distintas. Não se pode, então, afastar a hipótese de retrabalhamento para este intervalo, dentro do mesmo contexto das rochas sobrepostas.

\subsection{5 - Síntese dos dados de campo}

O levantamento geológico de detalhe realizado ao longo de toda a faixa de afloramento, localizada nos flancos oeste e setentrional da Bacia do Paraná, bem como na parte paraguaia da bacia, possibilitou um melhor entendimento das relações estratigráficas e dos aspectos sedimentológicas das unidades pré-Permianas analisadas.

Com relação às unidades pré-Furnas, dentre as várias questões discutidas, devemos destacar os resultados alcançados quanto a distribuição geológica das mesmas. As diversas seções geológicas realizadas indicam que o registro sedimentar preservado, relativo a estas unidades, é, aparentemente, descontínuo. A possibilidade de uma descontinuidade no registro sedimentar pode ser agora introduzida em função da caracterização de sedimentos associados às unidades Vila Maria, Ponta Grossa e Aquidauana, ao longo da faixa de afloramento oeste e noroeste da bacia, a partir de rochas até então mapeadas de 
forma homogênea, ora como pertencentes à Formação Furnas, ora associadas a sedimentos do Ordoviciano-Siluriano.

$\mathrm{Na}$ maioria das seções levantadas as relações estratigráficas não são observadas de forma direta, fato que dificulta o estabelecimento de uma cronologia para os eventos causadores dessa descontinudade. A dificuldade em se caracterizar as relações estratigráficas das unidades, em especial na borda oeste da bacia é, também, o principal problema para definir a real distribuição dos sedimentos associados à Formação Alto Garças. Esses sedimentos, na concepção aqui estabelecida, só foram registrados com segurança na região da Chapada dos Guimarães e a noroeste do lineamento transbrasiliano. Utilizando-se somente os afloramentos como base de estudo, não se observam evidências para se diagnosticar um controle estrutural / tectônico na deposição desta unidade.

Por outro lado, a distribuição regional da Formação Vila Maria e a sua relação estratigráfica com a Formação Furnas indicam a presença de um possivel controle estrutural na preservação do registro final desta unidade. $\mathrm{Na}$ conceituação apresentada para a Formação Vila Maria, a mesma é composta por um conjunto basal arenoso, com intercalações de diamictitos, sobreposto por siltitos e folhelhos, que gradam para um conjunto arenoso regressivo no topo. A relação de contato é marcada por uma expressiva variação de espessura do conjunto regressivo, provavelmente ligado à erosão pré-Furnas. A perda de seção associada a esta erosão pode ser significativa, ocorrendo em alguns casos a ausência total dos sedimentos da Formação Vila Maria. Esta perda de seção em diferentes situaçōes está relacionada a grandes feições estruturais. Um caso exemplar ocorre junto aos alinhamentos de direção NW-SE presentes na região de Rio Verde de Mato Grosso e que, aparentemente, controlam a distribuição dos sedimentos. Ao norte destes alinhamentos não foram registrados sedimentos que seguramente possam ser associados à Formação Vila Maria. Esta situação se estende ao longo da parte central do flanco oeste da bacia até a falha de São Lourenço, próximo a Rondonópolis (MT). Ao norte desta falha observa-se 
novamente o registro da Formação Vila Maria. É importante ser ressaltado que ao longo da faixa de não-ocorrência dos sedimentos da Formação Vila Maria observa-se, em vários pontos, a deposição de sedimentos relacionados à Formação Furnas diretamente sobre o embasamento.

Uma questão em aberto, no entanto, é a definição se esta ausência do registro é por não-deposição ou erosão. No primeiro caso, teriamos que admitir uma forte influência do embasamento sobre a deposição dos sedimentos. Neste caso, a gênese e a história evolutiva do Granito São Vicente e outros correlatos, que ocorrem na região, podem ter um papel fundamental no controle da sedimentação. Por outro lado, se considerarmos que a ausência dos sedimentos está relacionada a uma perda por erosão, estariamos definindo um evento de mobilização de grande magnitude no tempo pré-Furnas.

A partir da análise realizada para os sedimentos devonianos alguns aspectos podem ser destacados. Foi possível diagnosticar a existência de uma relação genética bem definida entre os sedimentos da Formação Furnas e aqueles da Formação Ponta Grossa. Esta relação é explicitada em vários afloramentos, sobretudo naqueles que ocorrem no extremo nordeste da bacia. Para esta região as seções levantadas demonstram a existência de um progressivo afogamento por parte dos sedimentos marinhos da Formação Ponta Grossa que avançam progressivamente sobre a Formação Furnas até recobrirem o embasamento em direção à Bacia do Parecis, demonstrando desta forma que, possivelmente, esta região da Bacia do Parecis figurava como uma borda de bacia para o tempo Furnas.

Com relação aos sedimentos devonianos um importante fator foi a identificação de sedimentos associados ao Membro médio da Formação Ponta Grossa na borda oeste e, também, na área da Bacia do Parecis. Estes sedimentos normalmente associados ao sudoeste de Goiás são agora mapeados por toda a extensão norte da bacia. Ainda com relação a estes sedimentos, foi possível 
melhor definir sua relação de contato com os sedimentos sotapostos, bem como inferir uma possivel intervalo de não deposição entre os sedimentos do Membro médio e aqueles sotapostos em função da idade dos folhelhos que estão sobrepostos aos arenitos do membro médio.

Ainda em termos litoestratigráficos, podemos destacar a identificação inédita da Formação Aquidauana na borda oeste da bacia, bem como no extremo nordeste da bacia, em áreas de influência do Lineamento Transbrasiliano. As relações estratigráficas observadas nestas novas localidades possibilitam aventar a hipótese de um possivel controle estrutural por parte deste lineamento na deposição da Formação Aquidauana. Confirmando-se este diagnóstico estariamos definindo um importante evento de mobilidade na Bacia do Paraná de idade préNeo-Carbonifera.

O estudo realizado na porção paraguaia da Bacia do Paraná permitiu estabelecer um novo arranjo estratigráfico para a seção pré-carbonífera da mesma. As conclusões apresentadas foram fortemente embasadas nos dados bioestratigráficos obtidos dos poços e furos de sondagem estudados. Dentre estas conclusões, destaca-se a tentativa de individualizar do pacote ordovício-siluriano os sedimentos que foram originalmente descritos como Formação Tobatí, aventando a possibilidade dos mesmos serem de idade mais jovem. Um segundo aspecto importante foi a redefinição da Formação Santa Elena e a sua correlação com os sedimentos da Formação Furnas no Brasil. 
2.2 - Dados Geológicos obtidos a partir de poços e furos de sondagem

\subsection{1 - Introdução}

Nesta pesquisa foram analisados poços perfurados pela Petrobrás e Paulipetro na Bacia do Paraná, no Brasil e pela Pecten e Anschutz, na parte paraguaia da bacia.

$\mathrm{Na}$ parte brasileira foram solicitados à Petrobrás 14 poços, 13 estratigráficos: 2-AG-1-MT, 2-CG-1-MT, 2-TL-1-MT, 2-DO-2-MT, 2-RA-1-MS, 2 RP-1-MT, 2-JA-1-GO, 2-AN-1-PR, 2-RI-1-PR, 2-LA-1-SP, 2-AR-1-SP, 2-OL-1-SP e mais o poço 3-CB-3-SP (Fig. 25). Na parte paraguaia da bacia foram solicitados, ao Departamento de Recursos Minerais do Paraguai, os seguintes furos de sondagem: RD-116, RD-115, 268-R1, 268-R2, 269-R1, 269-R3 e 269-R4 e os poços Asunción n. ${ }^{\circ} 1$ e Asunción n. ${ }^{\circ} 2$ (Fig. 26). Os poços foram estudados em termos sedimentológicos, sendo também coletado, quando possivel, material para a análise palinológica e geoquímica.

Nesta seção iremos apresentar os dados brutos obtidos a partir dos testemunhos e amostras de calha. As interpretações estratigráficas decorrentes do fatiamento dos poços, em termos de seqüências, serão objeto de discussão quando da análise da evolução sedimentar dos intervalos de tempo estudados.

2.2.2 - Dados obtidos na parte brasileira da bacia

Os dados da parte brasileira da bacia são provenientes da descrição de testemunhos e da coleta de material de calha e, também, de 


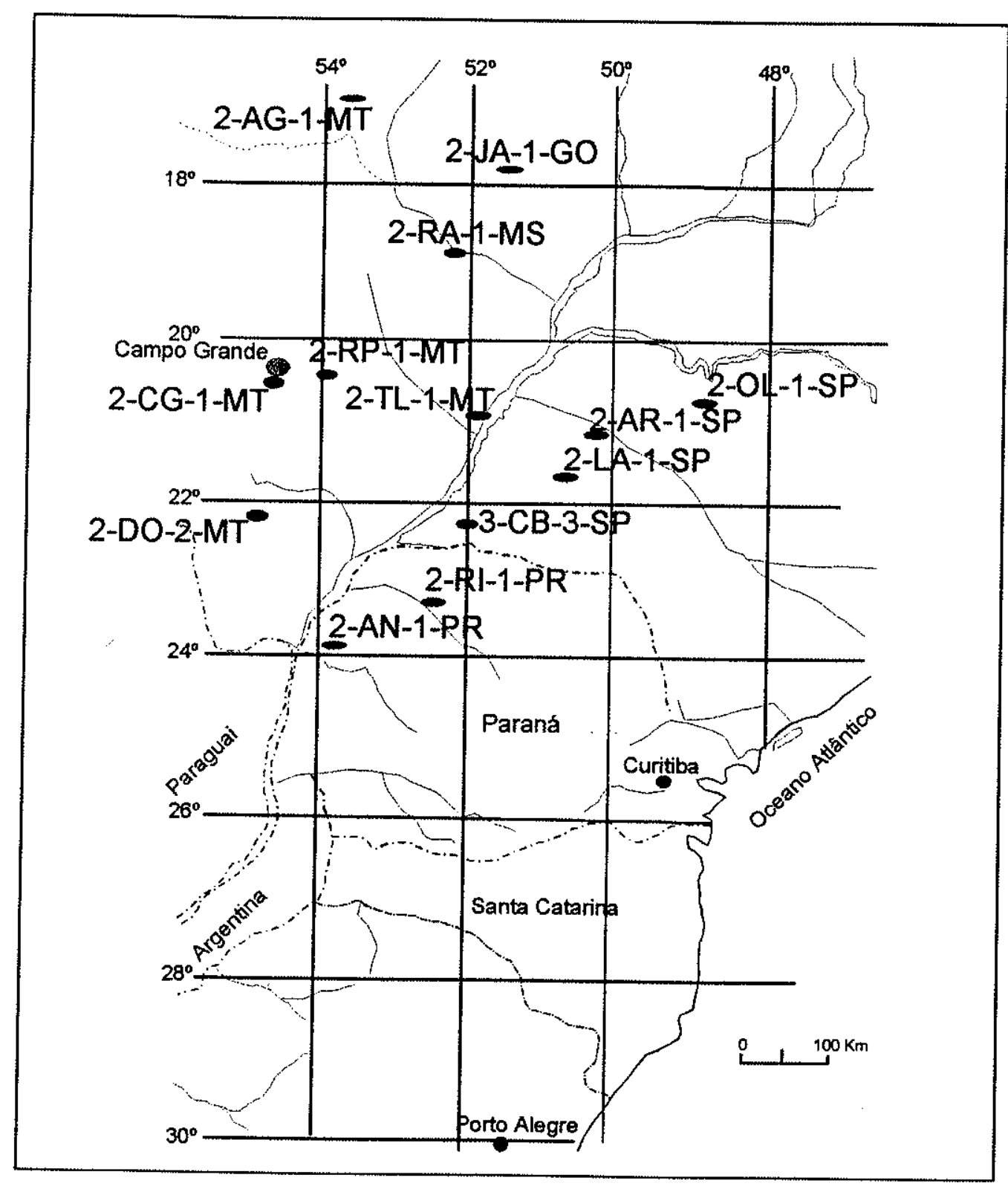

Fig. 25 - Localização dos Poços estudados nesta pesquisa 
testemunhos destinados à análise palinológica. A relação do material coletado pode ser observada na tabela abaixo (Tabela 1).

\begin{tabular}{|c|c|c|c|}
\hline POÇO & TESTEMUNHO & PROFUNDIDADE & FORMACAO \\
\hline 2-AG-1-MT & $\begin{array}{c}16 \\
17 \\
18 \\
. \quad 19 \\
20 \\
21 \\
22 / 23 \\
\text { calha } \\
\end{array}$ & $\begin{array}{l}1200 \\
1300 \\
1400 \\
1477 \\
1570 \\
1675 \\
1815 \\
1930 \\
\end{array}$ & $\begin{array}{l}\text { P. Grossa } \\
\text { P. Grossa } \\
\text { P. Grossa } \\
\text { Furnas } \\
\text { Furnas } \\
\text { Furnas } \\
\text { Alto Garças } \\
\text { Alto Garcas } \\
\end{array}$ \\
\hline 2-AN-1-PR & $\begin{array}{l}\text { calha } \\
\text { calha } \\
\end{array}$ & $\begin{array}{l}5350-5365 \\
5505-5510 \\
\end{array}$ & $\begin{array}{l}\text { P. Grossa (?) } \\
\text { P. Grossa }\end{array}$ \\
\hline 2-AR-1-SP & $\begin{array}{c}\text { Calha } \\
\text { Calha } \\
04 \\
\end{array}$ & $\begin{array}{c}2925-2975 \\
3250 \\
3450 \\
\end{array}$ & $\begin{array}{l}\text { P. Grossa (?) } \\
\text { P. Grossa (?) } \\
\text { Furnas (?) }\end{array}$ \\
\hline 2-CG-1-MT & $\begin{array}{c}22 \\
\text { calha } \\
23 \\
24 \\
\text { calha } \\
\end{array}$ & $\begin{array}{c}2160 \\
2205-2215 \\
2240 \\
2280 \\
2495-2520 \\
\end{array}$ & $\begin{array}{c}\text { Itararé(?) } \\
\text { Itararé(?) } \\
\text { Furnas } \\
\text { Furnas } \\
\text { Furnas (?) } \\
\end{array}$ \\
\hline 2-DO-1-MT & $\begin{array}{c}51 \\
\text { calha } \\
52 \\
\end{array}$ & $\begin{array}{r}3800 \\
3879 \\
4115 \\
\end{array}$ & $\begin{array}{c}\text { Itararé(?) } \\
\text { Itararé(?) } \\
\text { Furnas } \\
\end{array}$ \\
\hline $2-\sqrt{A}-1-G O$ & $\begin{array}{c}29 \\
30 \\
31 / 32 \\
33 \\
34 \\
35 \\
36 / 37 / 38 \\
\end{array}$ & $\begin{array}{l}1735 \\
1770 \\
1800 \\
1835 \\
1925 \\
2010 \\
2150 \\
\end{array}$ & $\begin{array}{c}\text { Ponta Grossa } \\
\text { Ponta Grossa } \\
\text { Ponta Grossa } \\
\text { Ponta Grossa } \\
\text { Furnas } \\
\text { Furnas } \\
\text { Furnas } \\
\end{array}$ \\
\hline 2-LA-1-SP & $\begin{array}{c}13 \\
\text { calha } \\
\text { calha } \\
\text { calha } \\
\end{array}$ & $\begin{array}{c}3875 \\
3925-3950 \\
4018 \\
4340 \\
\end{array}$ & $\begin{array}{c}\text { Itararé } \\
\text { Ponta Grossa } \\
\text { Furnas } \\
\text { Furnas } \\
\end{array}$ \\
\hline $2-O L-1-S P$ & $\begin{array}{c}20 \\
21 \\
22 / 23 \\
24 / 25 \\
26 \\
27 \\
\end{array}$ & $\begin{array}{l}2150 \\
2240 \\
2270 \\
2305 \\
2370 \\
2535 \\
\end{array}$ & $\begin{array}{c}\text { Itararé (?) } \\
\text { P. Grossa } \\
\text { P. Grossa } \\
\text { P. Grossa } \\
\text { P. Grossa } \\
\text { Furnas } \\
\end{array}$ \\
\hline 2-RA-1-MS & $\begin{array}{l}\text { Calha } \\
\text { calha }\end{array}$ & $\begin{array}{c}2950-3000 \\
3420\end{array}$ & $\begin{array}{l}\text { Ponta Grossa } \\
\text { Furnas }\end{array}$ \\
\hline 2-RI-1-PR & $\begin{array}{l}\text { calha } \\
18 \\
\text { calha } \\
\end{array}$ & $\begin{array}{c}4815.4820 \\
5175 \\
5275 \\
\end{array}$ & $\begin{array}{c}\text { P. Grossa } \\
\text { Pré-Devoniano } \\
\text { Pré-Devoniano }\end{array}$ \\
\hline 2-RP-1-MT & $\begin{array}{c}17 / 18 \\
19 \\
24 \\
\end{array}$ & $\begin{array}{l}2810 \\
2887 \\
3270 \\
\end{array}$ & $\begin{array}{c}\text { P. Grossa } \\
\text { Furnas } \\
\text { Furnas } \\
\end{array}$ \\
\hline 2-TL-1MT & $\begin{array}{c}32 \\
33 \\
34 \\
35 \\
36 \\
37 \\
38 \\
\text { calha }\end{array}$ & $\begin{array}{l}4135 \\
4138 \\
4213 \\
4310 \\
4405 \\
4415 \\
4525 \\
4550 \\
\end{array}$ & $\begin{array}{c}\text { Ponta Grossa } \\
\text { Ponta Grossa } \\
\text { Furnas } \\
\text { Furnas } \\
\text { Furnas } \\
\text { Furnas } \\
\text { Furnas } \\
?\end{array}$ \\
\hline 3-CB-3-SP & $\begin{array}{l}\text { calha } \\
\text { calha }\end{array}$ & $\begin{array}{l}4900 \\
4950 \\
\end{array}$ & $\begin{array}{l}\text { Ponta Grossa } \\
\text { Ponta Grossa }\end{array}$ \\
\hline
\end{tabular}

Tabela 1 - Localização das amostras coletadas em poços da Petrobrás e Paulipetro. 


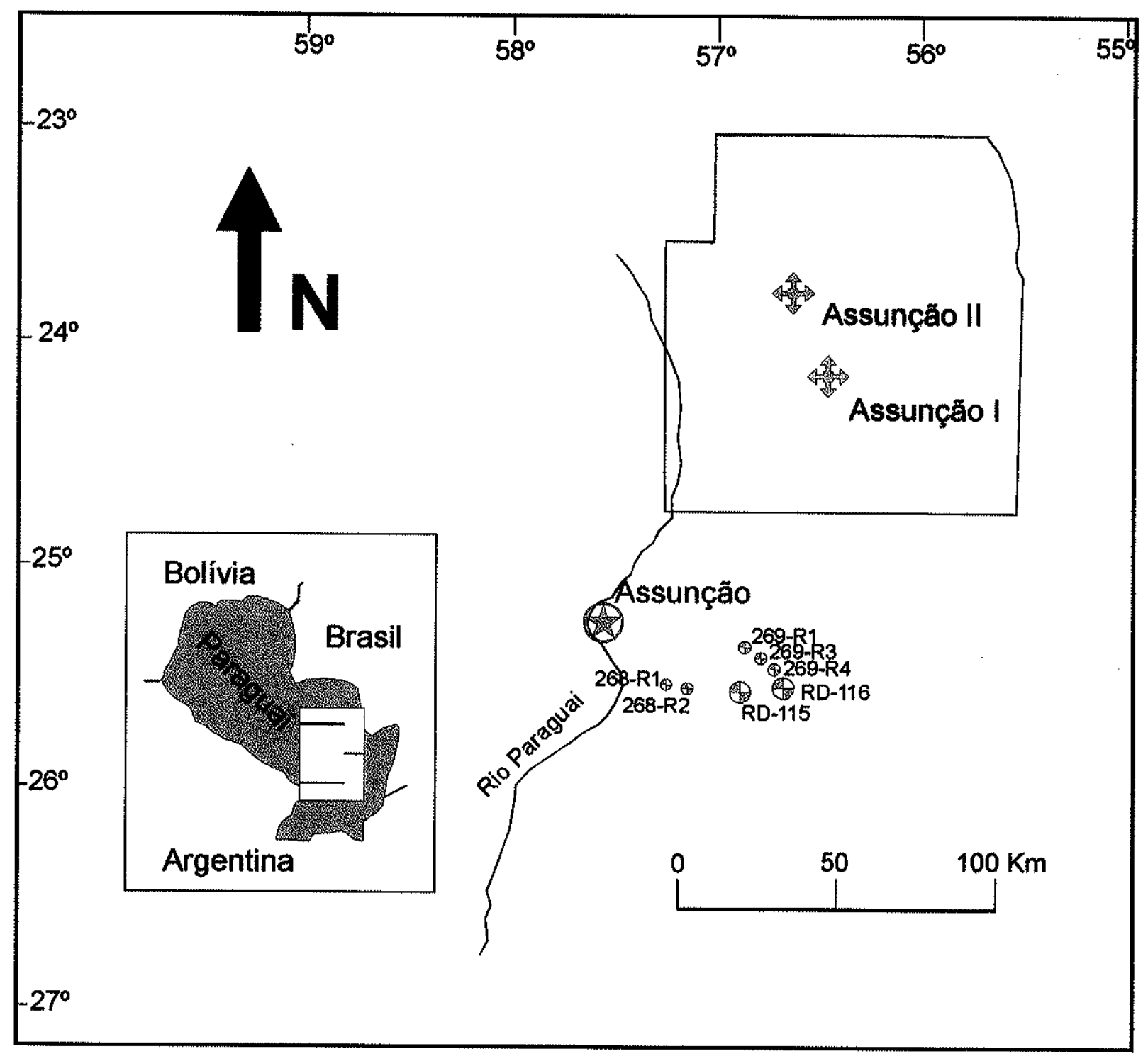

Fig. 26 - Mapa de localização dos poços Assunção I e II e dos furos de sondagem RD-116, RD-115, 269-R1, 269-R3, 269-R4, 268-R1 e 268-R2. 
Os resultados palinológicos obtidos a partir das amostras coletas são apresentados no capítulo 2.3. Com relação ao estudo sedimentológico, foram descritos 19 testemunhos envolvendo os seguintes poços: 2-AG-1-MT (\# 16, 17, 18, 19, 20, 22 e 23), 2-JA-1-GO (\# 29, 30, 31, 33, 34 e 36), 2-RP-1-MT (\# 17 e 18), 2-TL-1-MT (\# 34, 37 e 38), 2-RI -1-PR (\# 18), 2-OL-1-SP (\#27) e 2-AR-1-MT (\#4). A partir do estudo faciológico foram definidos os possiveis ambientes de sedimentação responsáveis pela deposição das rochas e que irão auxiliar no mapeamento dos ambientes deposicionais na âmbito da bacia. Nas figuras 27 (a e b), 28 ( $a$ e b), 29, 30 e 31 são apresentados os resultados deste estudo.

\subsection{3. - Dados obtidos na parte paraguaia da bacia}

$\mathrm{Na}$ porção paraguaia da bacia os furos de sondagem estudados foram testemunhados de forma contínua. Assim, os poços RD-116 e RD- 115 foram descritos em termos sedimentológicos (Fig. 32). Esses poços também foram amostrados, de forma contínua, visando os estudos bioestratigráficos e geoquímicos. Os resultados provenientes da análise bioestratigráfica serão apresentados em capítulo específico, sendo que os de geoquímica serão analisados junto a discussão da evolução sedimentar das seqüências sedimentares definidas na pesquisa.

Os poços Asunción 1 e Asunción 2 não possuem testemunhos de sondagem, o que impossibilita uma acurada definição dos ambientes de deposição envolvidos na sedimentação. Em função de existirem somente amostras de calha, esses poços só foram amostrados sistematicamente para o estudo bioestratigráfico. Os resultados desses estudos são apresentados no capítulo 2.3 . 

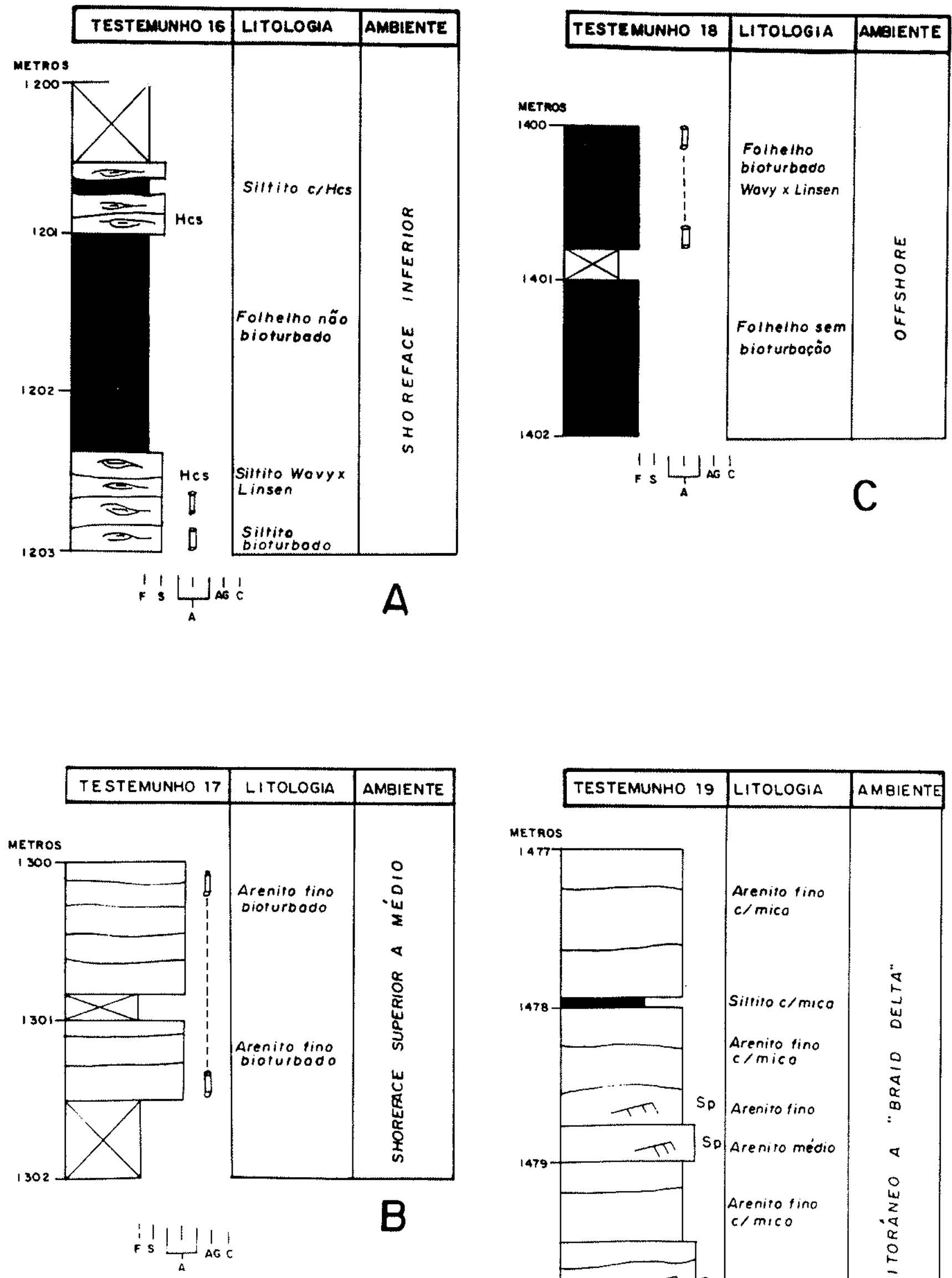

Fig. 27 (a) - Perfis sedimentológicos realizados em testemunhos do poço 2-AG-1-MT.

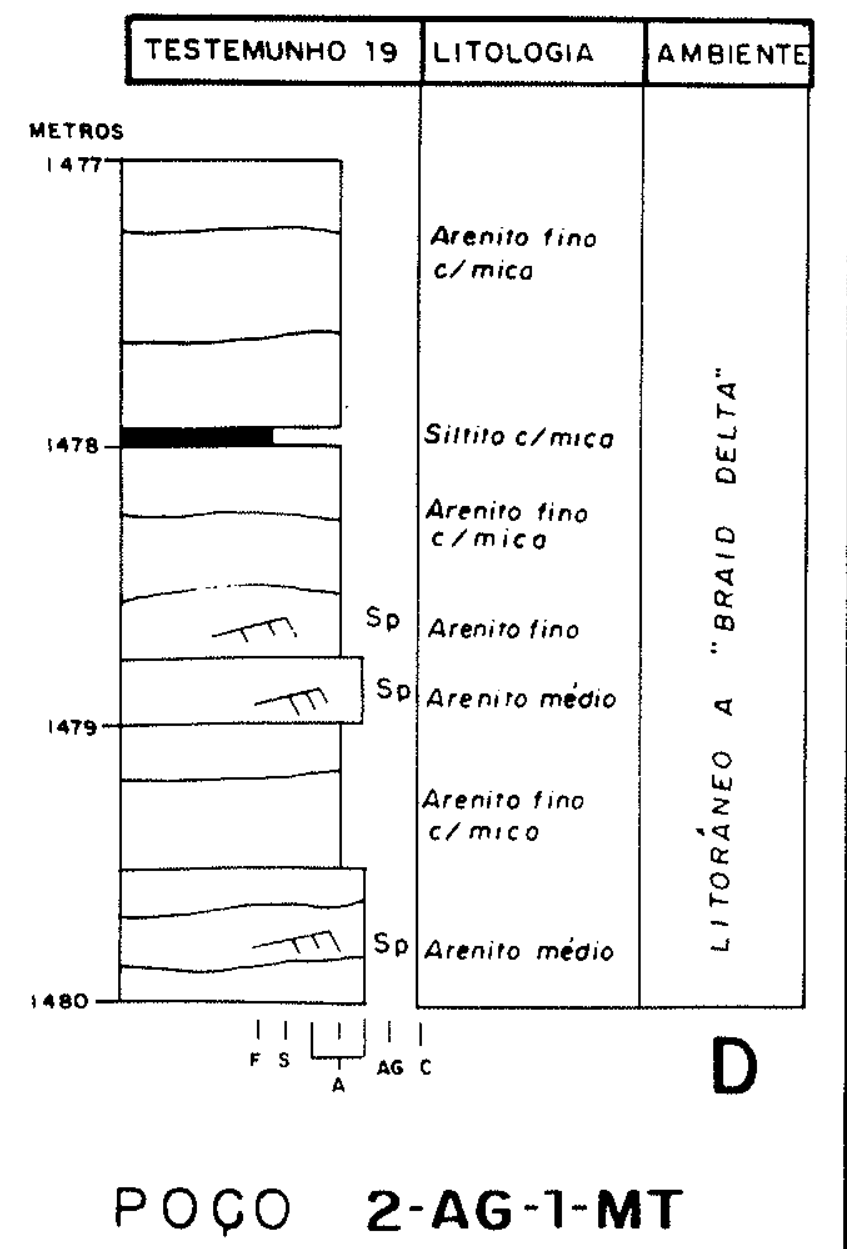



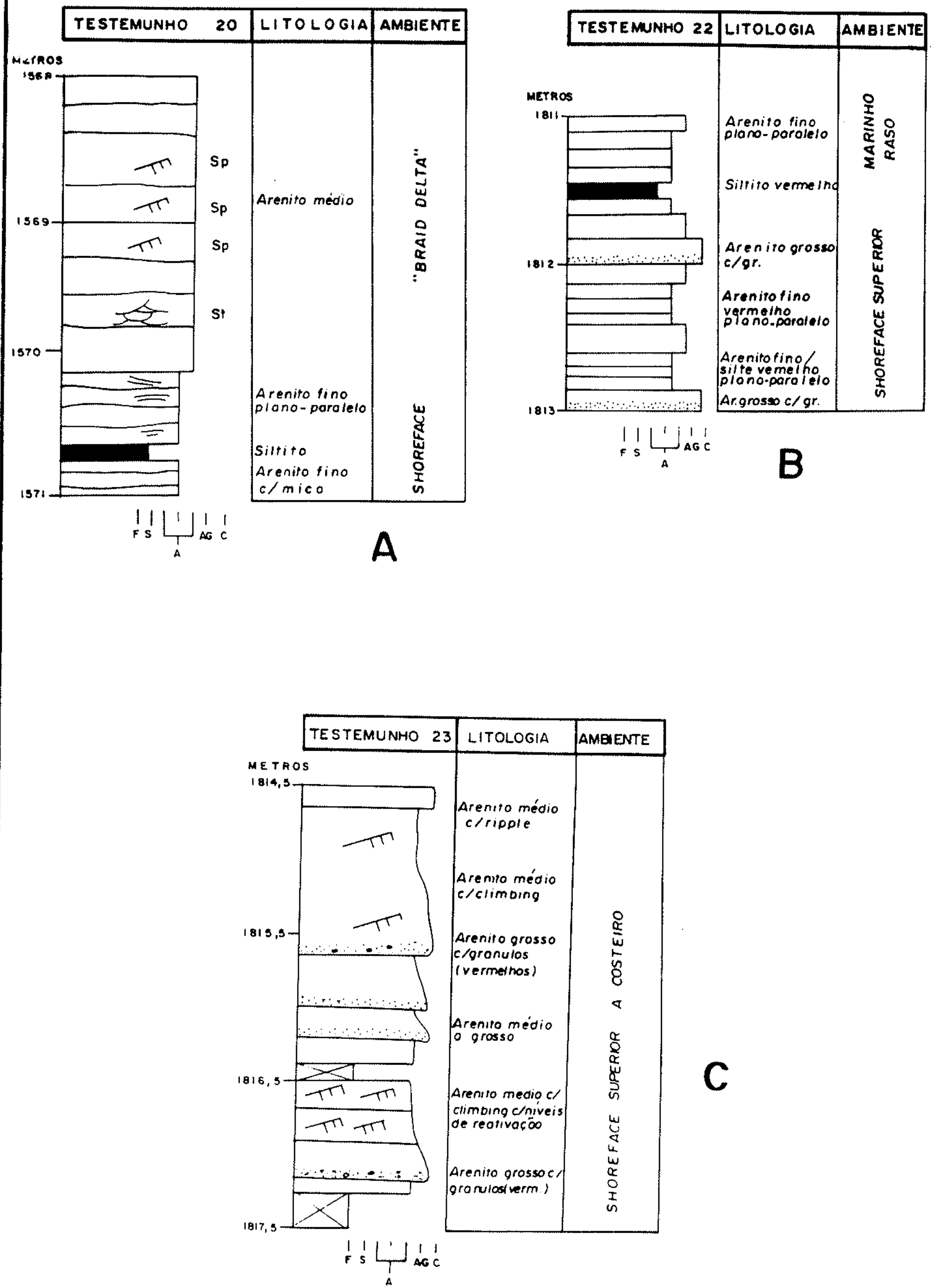

Fig. 27 (b) - Perfis sedimentológicos realizados em testemunhos do poço 2-AG-1-MT. 


\section{3- Dados Bioestratigráficos}

\subsection{1- Introdução}

A Estratigrafia de Seqüências, como já visto, é definida como o estudo das relações das rochas dentro de um arcabouço cronoestratigráfico. Neste novo contexto da análise estratigráfica, a questão da definição temporal dos eventos passa a ser uma das bases desta análise. Assim, o estudo da base de dados paleontológicos visando a definição das idades relativas das rochas ganha uma nova dimensão.

Esse aspecto passa a ter uma importância ainda maior quando o objeto de estudo é a Bacia do Paraná, na qual podemos dizer que nenhuma revisão bioestratigráfica geral foi realizada após os trabalhos de Lange (1967) e Daemon et al. (1967), utilizados por décadas como referência.

Nos últimos anos, no entanto, algumas contribuições geraram novos paradigmas para análise bioestratigráfica na Bacia do Paraná.

Gray et al. (1985) comprovaram, pela primeira vez, a idade siluriana para os sedimentos da Formação Vila Maria, na sua localidade tipo, baseados em dados palinológicos. Esta datação foi posteriormente confirmada em outros afloramentos, como também em poços (Grahn, 1992; Laranjeira et al., 1997). Grahn (1992) realizou, ainda, um sumário sobre o estado-da-arte da bioestratigrafia da Bacia do Paraná, com base em quitinozoas

A descoberta de fragmentos de plantas vasculares em lentes argilosas da parte superior da Formação Furnas, primeiro na margem nordeste da bacia (Quadros \& Melo, 1986) e, posteriormente, nas margens sudeste e noroeste (Rodrigues et al., 1989; Mussa et al., 1991, 1996; Schubert \& Borghi, 1991; Bolzon et al., 1994), possibilitou novas oportunidades para a determinação de uma idade 
para a Formação Furnas, bem como estabeleceu outros parâmetros para a correlação dessa unidade, em termos regionais, utilizando-se dos dados paleobotânicos.

Dino \& Rodrigues $(1991,1995)$ contribuíram de forma significativa para o estudo bioestratigráfico ao demostrarem a existência de sedimentos de idade pré-Emsiana na Bacia do Paraná. Loboziack et al. (1995), além de confirmar a idade Lochkoviano-Praguiano para a porção mais superior da Formação Furnas e para a base da Formação Ponta Grossa, também registraram, pela primeira vez, a existência de palinofloras do Fameniano tardio ("Struniano") em sedimentos da Bacia do Paraná.

Oliveira (1997) realizou um estudo palinológico detalhado, com base em acritarcos, para o conjunto sedimentar devoniano da bacia no Brasil, Paraguai e Uruguai, dando continuidade ao trabalho realizado pela mesma autora em 1991 (Oliveira, 1991).

No trabalho de Oliveira (1997) existe um equivoco importante que distorce os dados bioestratigráficos apresentados para a região paraguaia. Nos poços AS-I e AS-II, as coletas realizadas pela autora estenderam-se até a profundidade 2100 metros em ambos os poços. Este controle da coleta se baseou nas descrições originais dos poços realizadas pela Pectem que indicavam o limite siluriano / devoniano nesta profundidade. Contudo, os estudos palinológicos preliminares realizados por Milani \& Daemon (1992) já haviam demonstrado a possibilidade da existência de rochas devonianas abaixo deste limite original. Assim, os resultados apresentando por Oliveira (1997), indicando a inexistência de sedimentos de idade Eo-devoniana na parte paraguaia da Bacia do Paraná são incorretos, como será aqui demostrado. 

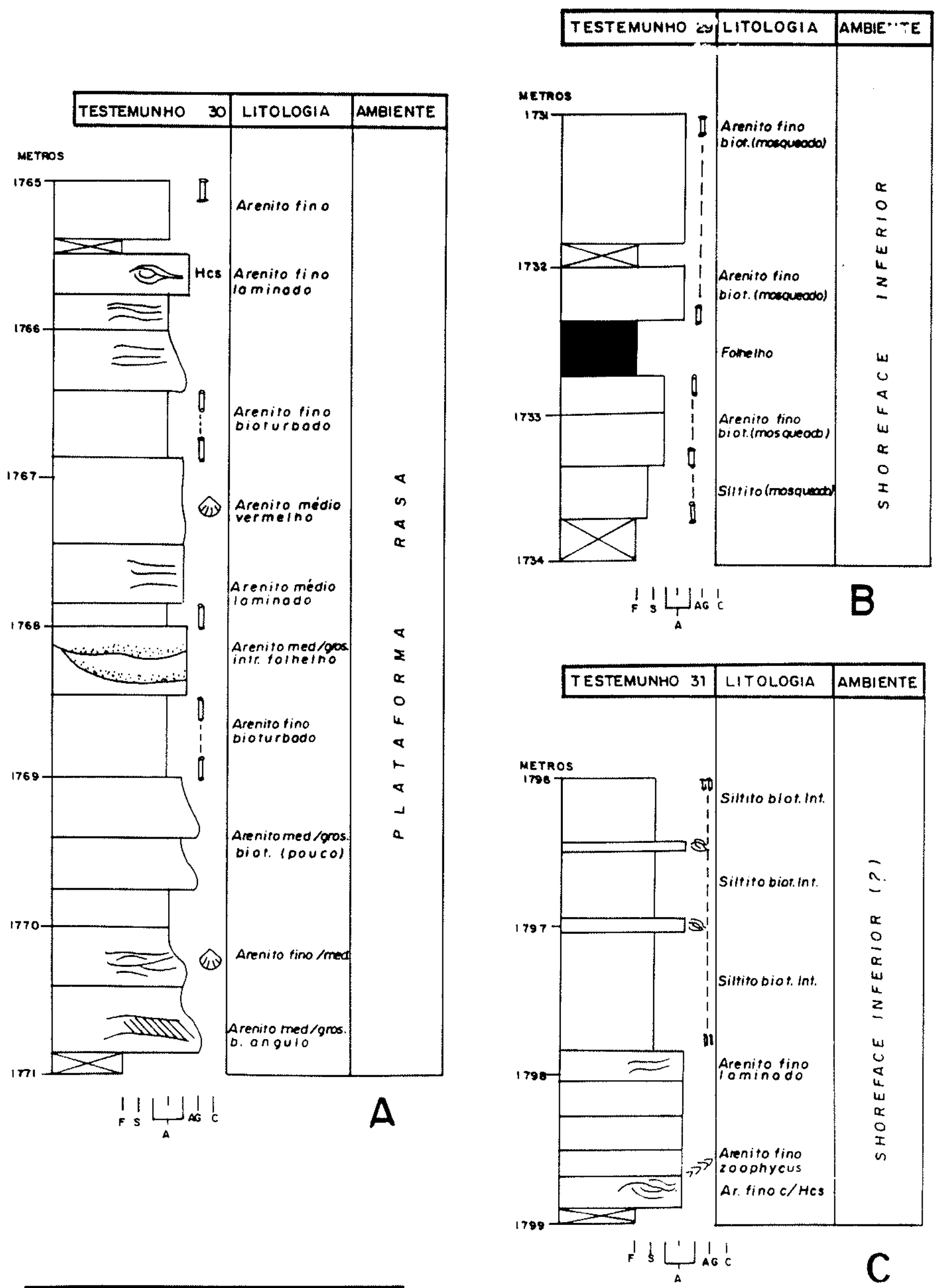

Fig. 28 (a) - Perfis sedimentológicos realizados em testemunhos do poço 2-JA-1-GO. 
Grahn et al. (in press, 1999) propuseram uma detalhada subdivisão bioestratigráfica do intervalo Siluro-Devoniano da bacia, através de uma extensa revisão e atualização dos dados referentes aos quitinozoas presentes na Bacia do Paraná, no Brasil e em países vizinhos. Esta revisão foi possível a partir da coleta sistemática de amostras realizada ao longo deste programa de pesquisa, objetivando o" zoneamento bioestratigráfico da seção compreendida entre o Ordoviciano e o Devoniano, através da utilização de diferentes ferramentas palinológicas.

As investigações acima mencionadas mostram que ao longo dos últimos anos foram realizados trabalhos especificos, ora pontuais, ora de caráter mais regional, visando a análise palinológica dos estratos siluro-devoniano da bacia. Contudo, os estudos realizados não objetivaram a construção de um arcabouço bioestratigráfico integrado, envolvendo as diferentes ferramentas palinológicas.

Neste contexto, ao longo desta pesquisa realizamos uma coleta sistemática de amostras, em poços e afloramentos, englobando os sedimentos ordovicianos, silurianos e devonianos, na parte brasileira e paraguaia da Bacia do Paraná. As amostras coletadas em duplicata foram processadas e estudadas para quitonozoários na Universidade do Estado do Rio de Janeiro, pelo Dr. Yngve Grahn e foi por nós estudada, para esporos e criptosporos, na Universidade de Liège - Bélgica, sob a supervisão do Dr. Philippe Steemans do Laboratório de Palinologia desta Universidade.

Este laboratório (Services Associés de Paleontologie de L'Université de Liège) é um dos centros de pesquisas palinológicas mais conceituados da Europa. O mesmo tem como principal atividade de pesquisa o estudo paleobotânico, paleopalinológico e micropaleontológico dos sedimentos paleozóicos. Neste laboratório, são aplicadas as mais modernas técnicas de preparação palinológica, fato fundamental, uma vez que em função da intensa 
ação intempérica a que estão submetidas as rochas no Brasıl, há uma grande dificuldade em se obter amostras que possuam alto indice de matéria orgânica preservada. Normalmente, as rochas sofrem uma intensa oxidação que elimina quase toda a matéria orgânica. Assim, para se obter resultados satisfatórios é necessário realizar um tratamento mais específico, que envolve uma série repetitiva de ataques químicos, em cilindros rotativos, bem como processos de filtragem à vácuo, entre outras técnicas que são aplicadas neste laboratório.

O trabalho desenvolvido possibilitou atingir um dos principais objetivos estabelecidos nesta pesquisa, no que se refere a análise palinológica, que foi o de desenvolver um arcabouço bioestratigráfico geral para os sedimentos do Paleozóico Inferior da Bacia do Paraná, em especial na parte paraguaia da bacia.

\subsection{2 - Material e Método}

Durante a pesquisa, foram tratadas 179 amostras: 131 provenientes do Paraguai e 48 coletadas no Brasil. Diferentes métodos de preparação foram utilizados, envolvendo variações na concentração dos ácidos e no tempo de reação.

As amostras paraguaias foram coletadas a partir dos seguintes poços: Assunção le Assunção Il; e dos furos de sondagem RD-116 e RD-115. As amostras brasileiras foram obtidas a partir dos poços perfurados pelas companhias Petrobrás e Paulipetro: 3-CB-3-SP, 2-CG-1-MT, 2-RA-1-MS, 2-AG-1MT, 2-LA-1-SP, 2-DO-1-MT, 2-AR-1-SP, 2-RI-1-PR, 2-TL-1-MT, 2-AN-1-PR, 2-JA1-GO e a partir de afloramentos (E9 - P. 04; P. 11; P. 39; P. 41; P. 45; P. 47 e E3 P. 01; P. 04; P 10; P. 11). 
Fig. 29 - Perfil sedimentológico realizado a partir dos testemunhos 17 e 18 do poço 2-RP-1-MT.

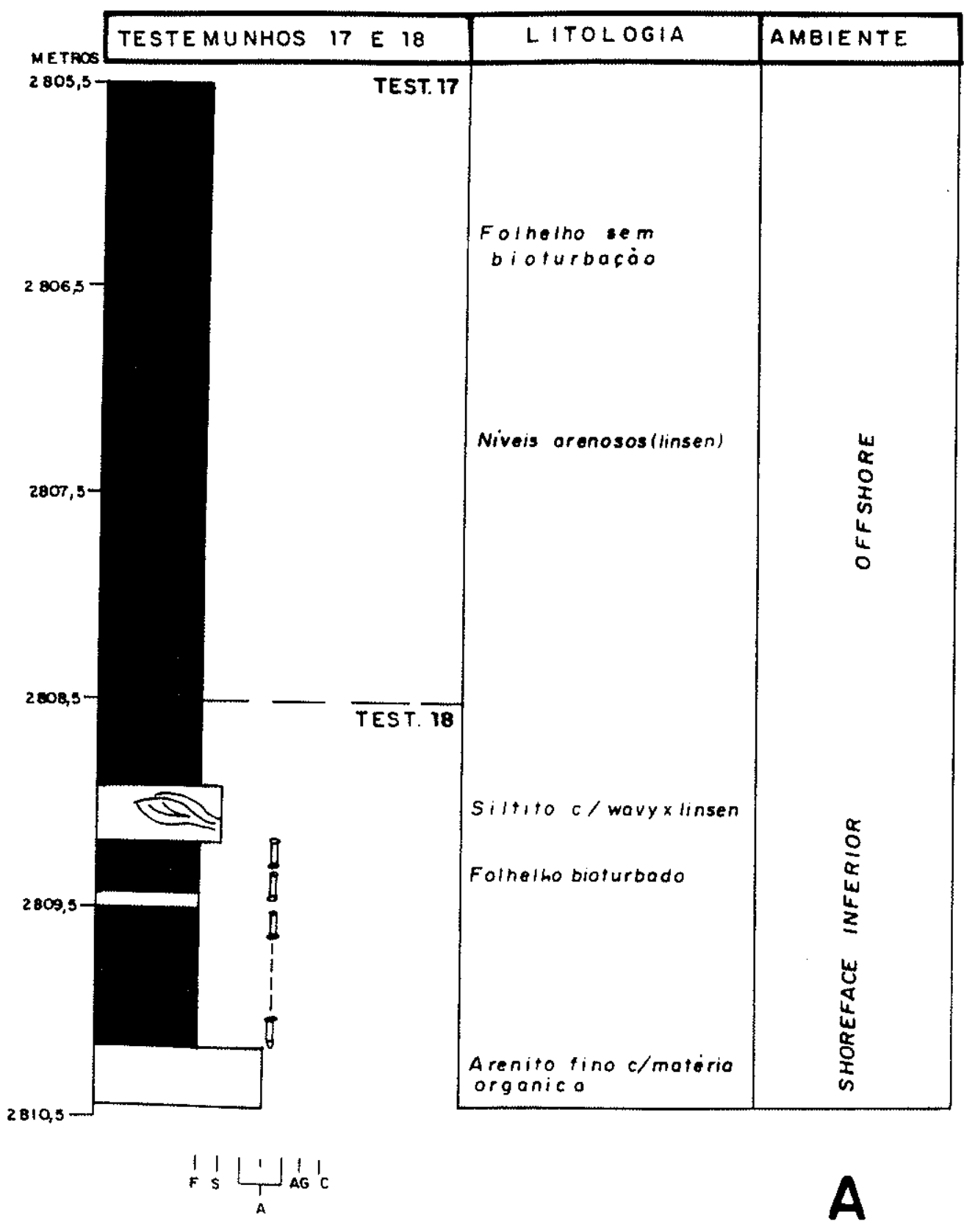

POCO 2-RP-1-MT 
Das 179 lâminas preparadas, foram escolhidas 126 para estudo. 0 conjunto de lâminas estudadas permitiu a obtenção de uma melhor visão do arcabouço bioestratigráfico dos sedimentos do Eopaleozóico da Bacia do Paraná.

As lâminas foram produzidas visando o estudo bioestratigráfico do conjunto sedimentar mais basal da Bacia do Paraná, envolvendo sedimentos com idades variando entre o Ordoviciano ao Eodevoniano, utilizando-se como elemento de estudo os esporomorfos, ou seja, criptosporos e esporos.

Os criptosporos são palinomorfos provavelmente derivados de plantas não marinhas (Richardson, 1996). Os mesmos possuem três tipos morfológicos distintos: mônades, díades e tétrades, que podem estar envoltos por membranas, ornamentadas ou não (Steemans, 1999). Segundo Steemans, (1999) os cripotsporos mais antigos foram encontrados em sedimentos do Eo-ordoviciano (Llanvirniano) da Arábia Saúdita e República Checa. Os criptosporos desaparecem completamente durante o Lochkoviano, sendo que sua maior diversidade ocorre no período pós-Llandoveriano. Durante o Llandoveriano a diversidade do grupo decresce, atingindo seu nível mais baixo no intervalo Telyciano - Sheinwoodiano. A curva de biodiversidade dos criptosporos é aproximadamente paralela à curva de variação global do nivel do mar (Kaljo et al., 1995; apud Steemans, 1999).

Os esporos são palinomorfos originados a partir das plantas terrestres. Os mesmos são liberados aos milhares no ambiente pela abertura dos esporângeos de uma população vegetal (Steemans, 1989). Os esporos triletes mais antigos foram diagnosticados por Steemans et al. (1996), na Turquia, em sedimentos de idade Ashgilliana. A biodiversidade dos esporos triletes amplia-se significativamente durante o Neo-Siluriano e o Devoniano. 

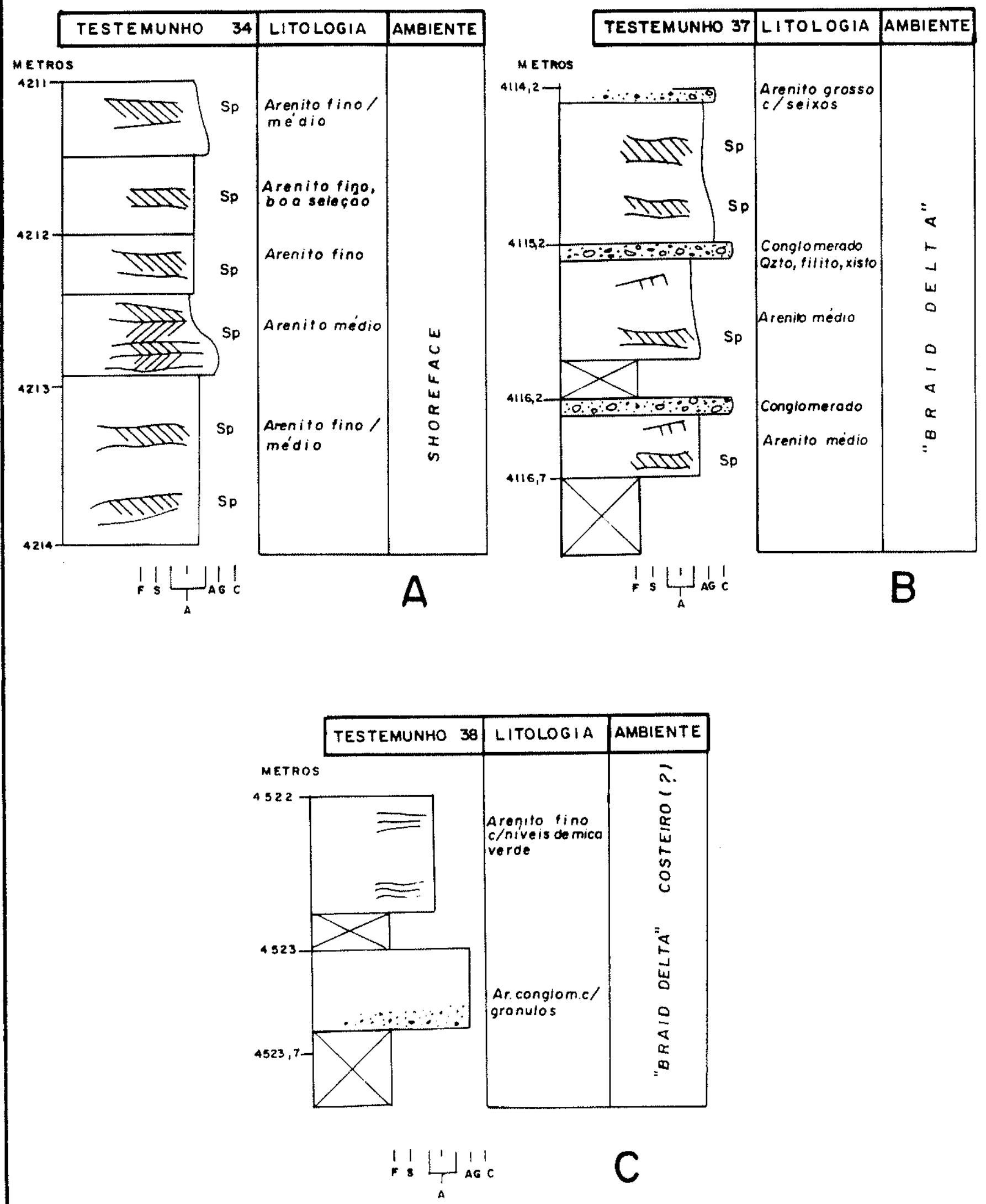

Fig. 30 - Perfis sedimentológicos realizados em testemunhos do poço 2-TL-1-MT. 
Os esporomorfos com marca trilete real, observada sobre sua superfície proximal, e com um tamanho, menor que 200 um, arbitrariamente definido, são referidos como miosporos.

A identificação dos gêneros e espécies foi realizada utilizando-se microscópio óptico normal e tendo por base várias publicações específicas, destacando-se entre as mesmas as seguintes: Richardson \& Lister (1969), McGregor (1973), McGregor \& Camfield (1976), McGregor (1977), Miller \& Eames (1982), McGregor (1984), Richardson \& McGregor (1986), Steemans (1989), Burgess \& Richardson (1991, 1995), Richardson (1996), Steemans et al. (1996), Streel \& Loboziak (1996), Wang et al. (1997).

Os resultados alcançados neste estudo, em especial para a parte paraguaia da bacia, trouxeram novas informações sobre as idades dos sedimentos, as quais são importantes para o entendimento da evolução geológica da bacia durante o Paleozóico.

\subsubsection{1 - Método de Preparação das Amostras}

O método de preparação das amostras compreende três diferentes etapas:

a) Limpeza das amostras e ataque com ácido fluoridrico;

b) Ataque com solução de Schutz e filtração dos resíduos; e

c) Preparação das lâminas

A primeira fase consiste no ataque com ácido fluoridrico sobre as amostras previamente limpas. Este ataque dura toda uma noite e ocorre em equipamento especial desenvolvido pelo Laboratório de Palinologia da Universidade de Liège. O equipamento possui três rolos que permanecem em 
contínuo movimento de rotação. $U$ movimento contínuo produz um ataque mais eficiente, o que possibilita a total destruição dos fragmentos de rocha.

O resíduo resultante é submetido a um novo ataque químico com a solução de Schultz. O objetivo desta reação é a oxidação da matéria orgânica de forma a torná-la mais clara. O tempo de reação depende das características das amostras e, em algumas situações, pode ser necessário repetir esta reação várias vezes.

Terminado este procedimento inicia-se a filtração do residuo. Esta filtração é feita sobre pressão. O sistema utilizado para a filtração permite a alternância de condições de pressão e vácuo sobre os resíduos. Tal procedimento possibilita a concentração da matéria orgânica.

As lâminas são montadas sobre uma base formada por um líquido viscoso composto por hydroscyaethylcelulose e álcool. Esta base permite uma maior dispersão do resíduo orgânico na lâmina.

\subsubsection{2 - Método Normal de Preparação das Amostras}

A metodologia usual do Laboratório de Palinologia foi aplicada no tratamento das amostras. Esta metodologia compreende uma série de procedimentos, conforme descritos abaixo, e envolve diferentes filtrações e reações químicas.

a) Fase I

1- Checar a ocorrência de carbonatos.

II - Lavar as amostras e secá-las. 


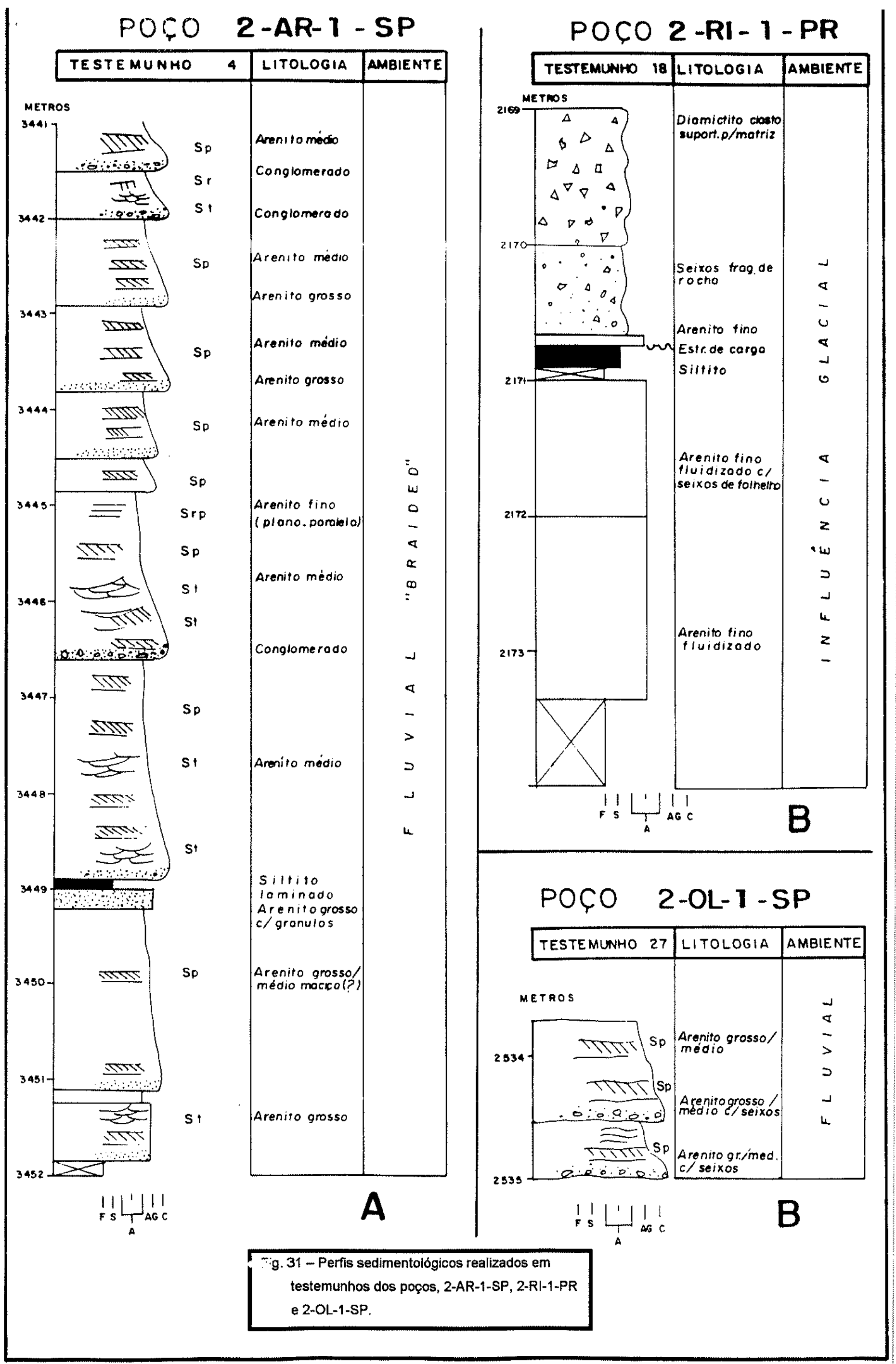


III - Quebrar as amostras em pequenos fragmentos $(+/-1 \mathrm{~mm}) \epsilon$ colocar $25 \mathrm{~g}$ deste material em um frasco de plástico.

IV - Neste frasco adicionar $150 \mathrm{ml}$ de ácido fluorídrico (40\%).

$V$ - Colocar o(s) frasco(s) sobre os rolos e deixá-los em contínua rotação por 16 horas.

b) Fase II

1 - Lavar os frascos com água e transferir o resíduo orgânico para um novo frasco. Colocar este novo frasco para centrifugar por 5 minutos sob 3000 rpm.

II - Eliminar os ácidos e repetir o procedimento anterior.

III - Lavar novamente com água o resíduo orgânico e transferi-lo para um frasco de vidro. Centrifugar o material por 5 minutos sob 3000 rpm.

IV - Eliminar a água.

$V$ - Atacar o resíduo com solução de Schutz $\left(\mathrm{HNO}_{3}+\mathrm{KCL}\right)$ por 2 horas. Dependendo das características das amostras, o ataque pode ser realizado somente com ácido nítrico.

VI - Após o procedimento anterior, inicia-se a filtração sob pressão usando filtro de 12 micra.

VII - Lavar o resíduo orgânico retido no filtro com água e transferi-lo para um becher. Neste becher, adicionar ao resíduo, ácido clorídrico e aquecer o material até a ebulição por 5 minutos.

VIII - Lavar os filtros em um equipamento de ultra-som e repetir o processo de filtração sob as mesmas condições.

IX - Transferir o resíduo orgânico retido no filtro para um pequeno frasco, utilizando água destilada.

$X$ - Centrifugar o resíduo por 5 minutos a $3000 \mathrm{rpm}$.

XI - Eliminar a água. 
c) Fase III

I - Colocar o resíduo centrifugado sobre uma base composta por hydroscyaethylcelulose e álcool (HEC) em uma lâmina preliminar.

II - Secar a lâmina preliminar a baixas temperaturas.

III" - Preparar a lâmina definitiva sobre uma base composta por Euparol (Croma - 3C239).

\subsubsection{3 - Método Especial de Preparação das Amostras}

Em função da elevada concentração de minerais nas amostras obtidas dos furos de sondagem RD-116 e RD-115, foi necessário modificar a metodologia. Assim, foi utilizado o seguinte procedimento.

I - Finalizada a fase 1 do método normal, lavar os frascos com água e transferir o resíduo para novos frascos. Centrifugar o resíduo por 5 minutos sob $3000 \mathrm{rpm}$.

II - Eliminar o ácido e repetir o procedimento anterior.

III - Transferir o resíduo orgânico para um cadinho de níquel e adicionar uma pequena quantidade de ácido fluorídrico e aquecer por 5 minutos até a ebulição.

IV - Lavar os cadinhos com água e transferir o resíduo orgânico para um novo frasco. Centrifugar o resíduo por 5 minutos sob $3000 \mathrm{rpm}$.

V - Transferir o resíduo para um becher; adicionar ácido clorídrico técnico e aquecer até a ebulição por 5 minutos.

VI - Iniciar o processo de filtração. 


\subsection{3 - Resultados Palinológicos Obtidos}

Os resultados que são apresentados foram obtidos pelo estudo palinológico realizado com base na identificação de criptosporos, miosporos, quitinozoas e acritarcos. Assim, se tenta estabelecer um arcabouço bioestratigráfico integrado.

\subsubsection{1 - Amostras provenientes do Paraguai}
A) Furo de Sondagem RD - 116

O furo de sondagem RD-116 está localizado na parte leste do Paraguai. Esta área da Bacia do Paraná apresenta características geológicas similares à parte brasileira da bacia. Este furo foi perfurado pela Anschutz Minerals em 1980.

A partir deste furo foram coletadas 36 amostras de testemunhos, as quais foram tratadas e estudadas. Com base nas lâminas preparadas, foi possível identificar 20 gêneros de miosporos e 13 gêneros de cryptosporos (Tabela 2) que possibilitaram a definição das idades dos sedimentos.

O furo RD-116 pode ser dividido em três partes diferentes. A primeira é composta por uma sucessão contínua de sedimentos (402m a 99m), limitada em sua parte superior por uma discordância. No primeiro intervalo, na posição de 99,80 metros, é possível definir uma idade eo-wenlockiana, mais precisamente na transição Telychiano / Sheinwoodiano, utilizando-se como base a presença do acritarco Dactylofusa maranhensis para esta posição. Assim, a idade deste intervalo com base nos criptosporos, esporos e acritarcos encontrados, varia do Neo-Ordoviciano, para sua base, ao Eo-Wenlockiano. 


\begin{tabular}{|c|c|c|c|c|c|c|c|c|c|c|c|c|c|c|c|c|c|c|c|c|c|c|c|c|c|c|c|c|c|c|c|c|c|}
\hline Espécie/Prof. & \begin{tabular}{|}
0 \\
0 \\
0 \\
0 \\
\end{tabular} & $\begin{array}{l}0 \\
0 \\
0 \\
0 \\
0 \\
0\end{array}$ & $\begin{array}{l}1 \\
8 \\
\\
\overline{0}\end{array}$ & & $\begin{array}{l}\omega \\
\infty \\
\infty \\
0 \\
\mathbf{\infty} \\
\end{array}$ & 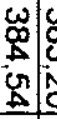 & & & $\begin{array}{l}\omega \\
0 \\
0 \\
\sigma \\
\end{array}$ & $\begin{array}{l}\omega \\
\tilde{G} \\
0 \\
\overrightarrow{0}\end{array}$ & & 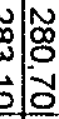 & $\mid \begin{array}{c}0 \\
G \\
G \\
0\end{array}$ & 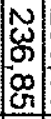 & & $\begin{array}{ll}\mathbf{w} & \\
\omega & \\
\infty & 0 \\
0 & 0\end{array}$ & 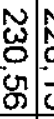 & 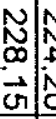 & & & & $\begin{array}{l}\overrightarrow{0} \\
w \\
\underline{\Delta}\end{array}$ & $\mid$\begin{tabular}{|c|}
$\overrightarrow{0}$ \\
$\omega$ \\
$\infty$ \\
0 \\
\end{tabular} & $\begin{array}{l}\vec{\Phi} \\
\vec{\sigma} \\
\vec{\sigma}\end{array}$ & & 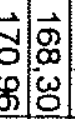 & $\left.\mid \begin{array}{l}\vec{A} \\
\omega \\
\vec{D}\end{array}\right]$ & & $\begin{array}{c}\bullet \\
\bullet \\
\infty \\
\varnothing\end{array}$ & & & & \\
\hline Tetrahedraletes medinensis & $\mathrm{x}$ & $\mathrm{x}$ & $x$ & $x$ & $x$ & $\mathrm{x}$ & $x$ & $x$ & $\mathrm{x}$ & $\mathrm{x}$ & $x$ & $x$ & $x$ & $x$ & $x$ & $x$ & $\mathrm{x}$ & \begin{tabular}{l|l}
$x$ & 2 \\
\end{tabular} & 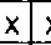 & $x \sqrt{x}$ & $x] x$ & $x$ & $\mathrm{x}$ & $x$ & $x$ & & & $x$ & $x$ & & & & \\
\hline Dyadospora murusdensa & $\mathrm{x}$ & $\mathrm{x}$ & $x:$ & $x$ & $\mathrm{x}$ & $x$ & & $x$ & $x$ & $x$ & & $x$ & $x$ & $x$ & $x$ & $x$ & $x$ & $x$ & & $x \mid x$ & $x$ & $x$ & $\mathrm{x}$ & $x$ & $x$ & & & & & $x$ & & & \\
\hline Lagvolancis divellomedium & $x$ & $x$ & $x$ & $x$ & $\underline{x}$ & $x$ & $\mathrm{x}$ & $x$ & $x$ & $x$ & $x$ & & $x$ & $\mathrm{x}$ & $x$ & \begin{tabular}{|l|l}
$x$ \\
\end{tabular} & $\begin{array}{ll}x \\
\end{array}$ & $x: 2$ & $x: 2$ & $x \mid x$ & $x \mid x$ & $\mathrm{x}$ & $x$ & & & & & & & & & & \\
\hline Rimosotetras problematica & $x$ & $x$ & & $x$ & $x$ & $x$ & & $\underline{x}$ & & & & & & $x$ & $x$ & & & & $x$ & & & & & & & & & & & & & & \\
\hline Velatitetras laevigata & & $x$ & $x$ & & & $\mathrm{x}$ & & $x$ & & & & & & & & & & & & & & & & & & & & & & & & & \\
\hline Velatitetras anatoliensis & & $\underline{x}$ & & & & & & & & & & & & & & & & & & & & & & & & & & & & : & & & \\
\hline Velatitetras retimembranifera & & & & & & & & & $x$ & & & & & & & & & & & & & & & & & & & & & & & & \\
\hline Velatitetras reticulata & & & & & & & & & & & & & & $x$ & & & & & & & & & & & & & & & & & & & \\
\hline Segestrespora laevigata & & & $\mathrm{x}$ & & $x$ & & $\mathrm{x}$ & & & $x$ & & & & & & & & & & & & & & & & & & & & & & & \\
\hline Rugosphera tosconviensis & & & & & & & & & & & & & & $\mathrm{x}$ & & & & & & & & & & & & & & & & & & & \\
\hline Rugosphera cerebra & & & & & & & & & & & & & & $x$ & & & & & & & & & & & & & & & & & & & \\
\hline Quadrisporites sp. & & & & & & & & & & & & & & $x$ & & & & & & & & & & & & & & & & & & & \\
\hline Ambitisporites (?)varurdovae & & & & & $x$ & & $x$ & & & & $x$ & & & & & & & & & $x$ & $x$ & & & & & & & & & 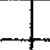 & & & \\
\hline Ambitisporites avitus-dilatus & & & & & & & & & & & $x^{\pi}$ & & $x^{*}$ & $x^{*}$ & & & & & $x$ & & & & $\mathrm{x}$ & $x$ & & 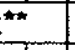 & & $x$ & $x$ & $x$ & & $x$ & \\
\hline Cryptospore (New genus 1) & & $x$ & $\mathrm{x}$ & & & $\underline{x}$ & & & & & & & & & & & & & & & & & & & & & & & & & & & \\
\hline Cryptospore (New genus 2) & & & & & & & & $x$ & & & & & & & & & & & & & & & & & & & & & & & & & \\
\hline Archaeozonotriletes chulus & & & & & & & & & & & & & & & & & & & $\left.x^{*}\right]$ & & & & & & & & & & & & & & \\
\hline Retusotriletes ssp. & & & & & & & & & & & & & & & & & & & & & & & & & $x^{\star \star}$ & & & & & $x$ & \begin{tabular}{c|c}
$x$ \\
$x$
\end{tabular} & $x$ & \\
\hline Acynorisporites sp. & & & & & & & & & & & & & & & & & & & & & & & & & & & & & & & $x$ & & \\
\hline Amicosporites sp. & & & & & & & & & & & & & & & & & & & & & & & & & & & & & & 2 & $x$ & & \\
\hline Apiculiretusispora ssp. & & & & & & & & & & & & & & & & & & & & & & & & & & & & & & $x[1$ & $x]$ & $6 x$ & \\
\hline Apiculiretusispora plicata & & & & & & & & & & & & & & & & & & & & & & & & & & & & & & & & $x$ & \\
\hline Apiculiretusispora pygmea & & & & & & & & & & & & & & & & & & & & & & & & & & & & & & & $\underline{x}$ & & \\
\hline Cymbosporites ssp. & & & & & & & & & & & & & & & & & & & & & & & & & & & & & & $x$ & $x$ & & \\
\hline Didolisporites echinaceus & & & & & & & & & & & & & & & & & & & & & & & & & & & & & & $\underline{x}$ & $x$ & $x$ & \\
\hline Emphanisporites rotatus & & & & & & & & & & & & & & & & & & & & & & & & & & & & & & $x$ & $x$ & 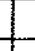 & \\
\hline Emphanisporites neglectus & & & & & & & & & & & & & & & & & & & & & & & & & & & & & & & & $x$ & \\
\hline Emphanisporites micromatus & & & & & & & & & & & & & & & & & & & & & & & & & & & & & & & $x$ & & \\
\hline Perotriletes sp. & & & & & & & & & & & & & & & & & & & & & & & & & & & & & & $x$ & $x$ & & \\
\hline Raistrickia sp. & & & & & & & & & & & & & & & & & & & & & & & & & & & & & & $x$ & & & \\
\hline cf. Rhabdosporites parvulus & & & & & & & & & & & & & & & & & & & & & & & & & & & & & & & & $x$ & 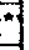 \\
\hline Samarisporites sp. & & & & & & & & & & & & & & & & & & & & & & & & & & & & & & $x$ & & L & \\
\hline Symorisporites papillensis & & & & & & & & & & & & & & & & & & & & & & & & & & & & & & $x$ & & $x$ & \\
\hline (?) Carboniferous miospore & & & & & & & & & & & & & & & & & & & & & & & & & & & & & & & $\underline{x}$ & & \\
\hline Leiotriletes sp. & & & & & & & & & & & & & & & & & & & & & & & & & & & & & $x$ & & & & \\
\hline & & & & & & & & & & & & & & & & & & & & & & & & & & & & & & & & & \\
\hline$x^{*}-$ Dúvida & & & & & & & & & & & & & & & & & & & & & & & & & & & & & & & & & \\
\hline$x^{* *}=c f$ & & & & & & & & & & & & & & & & & & & & & & & & & & & & & & & & & \\
\hline
\end{tabular}

Tabela 2 - Esporos e Cryptosporos identificados no furo RD-116. 
O segundo intervalo inicia-se com uma discordância em 99,00 metros. Na posição imediatamente acima desta discordância, em 75,62 m, a idade obtida com base em quitinozoas é Neo-Telychiana. Contudo, utilizando-se os esporos, a idade mínima obtida é Neo-Emsiano. Analisando-se o mesmo intervalo, com base em acritarcos (Dactylofusa striatifera) e na associação dos mesmos com os esporos zonados (Perotrilites $s p$.), a idade deste intervalo varia entre o NeoSiluriano a Lochkoviano. Assim, existe uma clara mistura de formas que indica uma idade mínima Neo-Emsiano para este intervalo. Em uma segunda amostra deste mesmo intervalo, na posição de $74,87 \mathrm{~m}$, esta mistura de formas fica bem evidenciada. O estudo realizado por José Henrique G. de Melo (comunicação escrita) confirma a presença dos seguintes elementos: Emphanisporites annulatus, Samarisporites sp., Camarozonotriletes ? concavus, Geminospora sp., Cymbosporites of catillus, Grandispora tabulata, Verrucosispora bulliferus, cf Lophonozotriletes sp. e Crucidia camirense; destacados de ampla maioria de palinomorfos de idade Llandoveriana. Esta assembléia indica que os sedimentos foram depositados em um contexto de retrabalhamento, de idade pós-Frasniana, em que a maioria do suprimento sedimentar proveio de áreas fontes silurianas e, secundariamente, de rochas do Devoniano médio e do Frasniano. O topo deste intervalo é marcado por uma nova quebra no registro sedimentar.

O terceiro intervalo inicia-se na posição de 54 metros e estende-se até 0 topo do furo. $O$ início deste intervalo é caracterizado pela presença de diamictitos. A idade do mesmo é no mínimo Namuriano em função da presença da gênero Potoneisporites observado nas lâminas preparadas a partir de amostras coletadas nas posições de 42,16 m e 43,57 m. (Estampa I) 


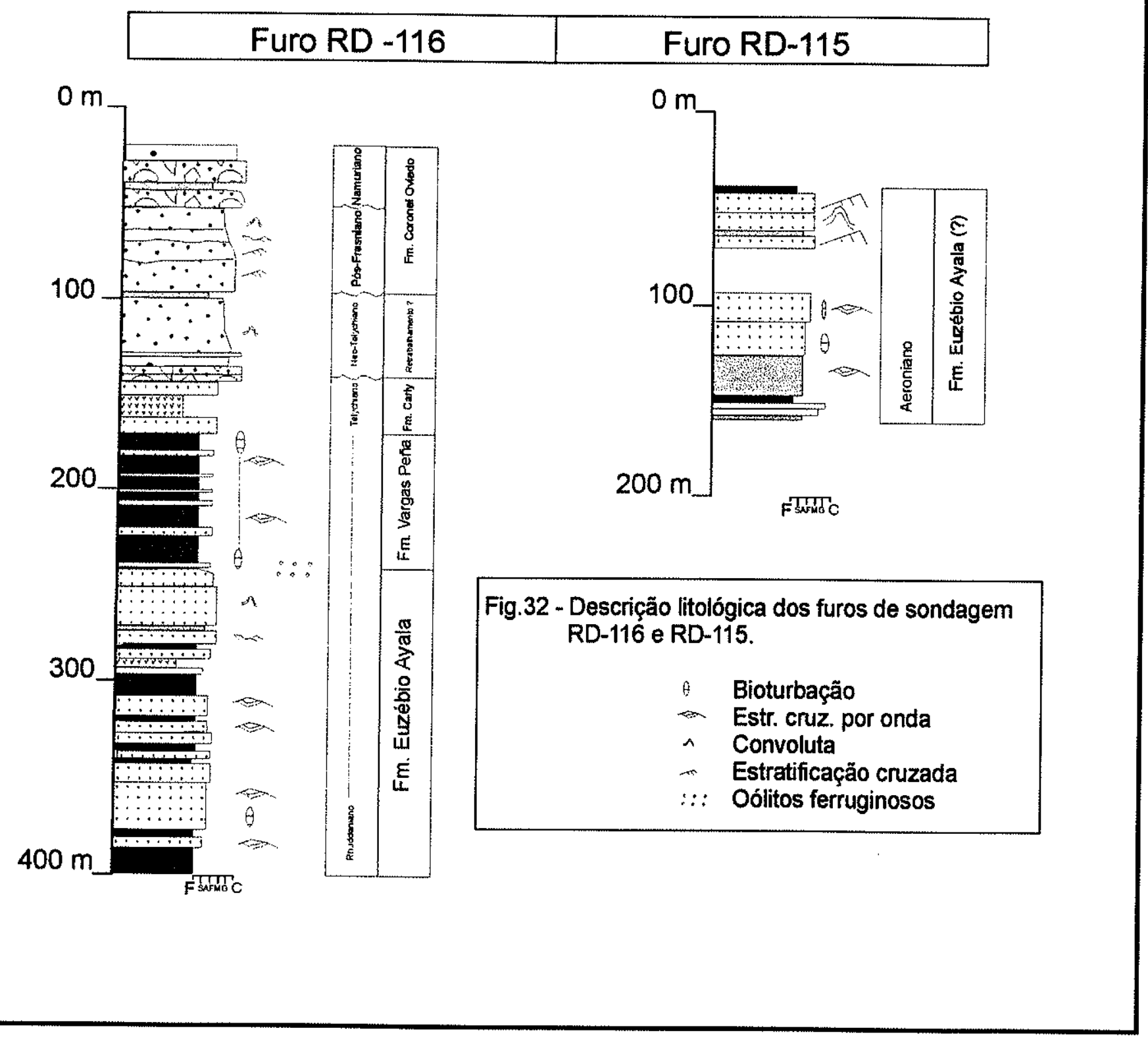


B) Furo de Sondagem RD - 115

O furo de sondagem RD-115 está localizado próximo ao furo RD116. Este furo também foi perfurado pela Anschutz Minerals em 1980. Possui 150 metros de profuñdidade e é composto por uma contínua sucessão sedimentar. Quinze lâminas foram preparadas a partir das amostras coletadas nos testemunhos do furo, sendo que todas foram estudadas.

Foram identificados nove gêneros de cryptosporos e dois gêneros de miosporos (Tabela 3). Em função do primeiro aparecimento da espécie Ambitisporites sp. ocorrer na profundidade de 101,35 metros, a idade dos sedimentos pode ser dividida em dois intervalos: a) de $150 \mathrm{~m}$ a $100 \mathrm{~m}$ e b) de $101 \mathrm{~m}$ até o final do furo. Para o primeiro intervalo, a idade dos sedimentos varia do Caradociano até o Ashgilliano e, para o segundo, varia do Neo-Ashgilliano até o Llandoveriano. Utilizando-se os dados de quitinozoários (Grahn et al., no prelo, 1999) pode-se definir uma idade Aeroniana para a base do furo.

\section{C) Poço Assunção 1}

O poço Assunção I foi perfurado pela companhia petrolífera Pecten em 1981. Trata-se do poço mais profundo da parte oriental do Paraguai, atingindo uma profundidade máxima de 3223 metros. O poço Assunção I corta uma espessa sucessão sedimentar de idade variando do Ordoviciano ao Permiano.

Quarenta e três (43) amostras foram tratadas. As mesmas foram coletadas a partir de sedimentos de calha, em dois diferentes intervalos: a) de 


\begin{tabular}{|c|c|c|c|c|c|c|c|c|c|c|c|c|c|}
\hline Espécie/Prof. & $\begin{array}{l}\vec{\sigma} \\
0 \\
\omega \\
\omega \\
\sigma\end{array}$ & $\begin{array}{l}\overrightarrow{\vec{\omega}} \\
\underline{\omega} \\
\omega\end{array}$ & $\begin{array}{l}\overrightarrow{\vec{a}} \\
\vec{\omega} \\
\vec{\omega}\end{array}$ & $\begin{array}{l}\vec{A} \\
\vec{a} \\
v\end{array}$ & $\begin{array}{l}\vec{\omega} \\
\mathbb{0} \\
\vec{\omega}\end{array}$ & $\begin{array}{l}\vec{\omega} \\
\omega \\
\omega \\
\omega\end{array} \mid$ & $\begin{array}{l}\vec{N} \\
\mathrm{c} \\
\mathrm{O}\end{array}$ & $\overrightarrow{\mid}$ & $\mid$\begin{tabular}{|l|} 
\\
0 \\
0
\end{tabular} & $\begin{array}{l}R \\
B \\
0\end{array}$ & $\begin{array}{l}\mathscr{S} \\
6 \\
\mathscr{O} \\
\end{array}$ & $\begin{array}{c}G \\
\mathbb{A} \\
\mathrm{N}\end{array}$ & $\overrightarrow{0}$ \\
\hline Tetrahedraletes medinensis & $x$ & $x$ & $x$ & & $\mathrm{x}$ & $\mathbf{x}$ & $x$ & $\mathbf{x}$ & $x$ & $x$ & $x$ & & $x$ \\
\hline Dyadospora murusdensa & $x$ & & $x$ & $\mathbf{x}$ & $x$ & $x$ & & $x$ & $x$ & $x$ & & & $x$ \\
\hline Laevolancis divellomedium & & & & & $x$ & $x$ & $x$ & $\mathrm{x}$ & $x$ & $x$ & $x$ & & $x$ \\
\hline Segestrespora laevigata & $x$ & & & & & & & & & & & & \\
\hline Rimosotetras problematica & $x$ & & & & & & $x$ & & & $x$ & $x$ & & \\
\hline Hispanaediscus sp. & & & $x$ & & & & & & & & & & \\
\hline Pseudodyadospora petasus & & & & & & & & & $x$ & & & & \\
\hline Velatitetras laevigata & & & & & & & & & $x$ & & & & \\
\hline Ambitisporites (?)varurdovii & & & & & & & & & & & $x$ & & \\
\hline Ambitisporites sp. & & & & & & & & $\mathbf{x}$ & & & & & \\
\hline Ambitisporites avitus-dilatus & & & & & & & & & & $\mathbf{x}$ & & & \\
\hline & & & & & & & & & & & & & \\
\hline
\end{tabular}

Tabela 3 - Esporos e Cryptosporos identificados no furo RD-115.

\begin{tabular}{|c|c|c|c|c|c|c|c|c|c|c|c|c|}
\hline Espécie/Prof. & $\begin{array}{l}N \\
\mathbf{w} \\
\mathbf{w} \\
0 \\
8 \\
8\end{array}$ & & & & & & & & & & & \\
\hline Tetrahedraletes medinensis & & $x$ & & & & & & & & $x$ & & \\
\hline Dyadospora murusdensa & & & & & & & & $x$ & & & & $x$ \\
\hline Laevolancis divellomedium & $x$ & & & & & & & & & & & \\
\hline Ambitisporites avitus-dilatus & & & & & & & & & & $x$ & & \\
\hline Ambitisporites (?)varurdovae & & & $\mathrm{x}$ & & & & & & & & & \\
\hline Miospore from Devonian & & $\mathrm{x}^{\star}$ & $x^{\star} \mid$ & & & & & & $\bar{x}$ & & & \\
\hline Archaezonotriletes chulus & & & & & & & & & & & & \\
\hline Aneurospora sp. & & & & & & & & & & & & \\
\hline Cymbosporites proteus & & & & & & & & & & & & \\
\hline Dibolisporites echinaceus & $x^{*}$ & & & & & & & & & & & \\
\hline & & & & & & & & & & & & \\
\hline$x^{*}$ - Contaminação & & & & & & & & & & & & \\
\hline
\end{tabular}

Tabela 4 - Esporos e cryptosporos identificados no poço Assunção I, no intenvalo entre 2835 e 2775 metros. 
$2835 \mathrm{~m}$ até $2770 \mathrm{~m}$ e b) de $2365 \mathrm{~m}$ até $2267,5 \mathrm{~m}$. Trinta e três (33) lâminas deste poço foram estudadas.

A partir das lâminas estudadas, foi possível identificar 09 gêneros de cryptosporos e 37 gêneros de miosporos. No primeiro intervalo (a), na profundidade de $2815 \mathrm{~m}$ ocorre, pela primeira vez, a espécie Archaezonotriletes chulus. Dessa forma, a idade dos sedimentos deste intervalo pode ser subdividida em dois diferentes conjuntos. No primeiro $(2835 \mathrm{~m}$ a $2817,5 \mathrm{~m})$, a idade varia do Caradociano ao Llandoveriano, e para o segundo $(2815 \mathrm{~m}$ a $2775 \mathrm{~m})$, a idade varia do Neo-Llandoveriano ao Eo-Wenlockiano (Tabela 4). Estas idades são pouco precisas. Contudo, utilizando-se os dados de quitinozoas (Grahn et al., no prelo, 1999), pode-se definir uma idade Aeroniana para todo intervalo estudado.

No segundo intervalo (b) foi possivel estabelecer uma boa divisão bioestratigráfica. Neste intervalo foram identificados 31 gêneros de miosporos e 05 gêneros de cryptosporos (Tabela 5). A assembléia descrita permite a definição de três diferentes zonas informais para o intervalo.

$\mathrm{Na}$ primeira zona $(2365 \mathrm{~m}$ a $2347,5 \mathrm{~m})$ a idade obtida varia do Pridoliano ao Lochkoviano. Na profundidade de $2347,5 \mathrm{~m}$ inicia-se a segunda zona. Nesta posição ocorrem os miosporos Cymbosporites multiconus e Cymbosporites dammamensis. Esta segunda zona continua até a profundidade de $2292,5 \mathrm{~m}$ e sua assembléia palinológica corresponde as Zonas $\mathrm{Si}$ e G de Steemans et. al. (1996). Esta assembléia indica uma idade Lochkoviana.

A última zona inicia-se na profundidade de $2292,5 \mathrm{~m}$ e continua, ao menos, até a profundidade de $2267,5 \mathrm{~m}$, posição da última lâmina preparada. $\mathrm{Na}$ posição de $2292,5 \mathrm{~m}$ ocorre, pela primeira vez, os miosporos Camptozonotriletes macrospinosus e Dibolisporites cf. efeliensis. Neste intervalo a assembléia 


\begin{tabular}{|c|c|c|c|c|c|c|c|c|c|c|c|c|c|c|c|c|c|c|c|}
\hline Espécie/Prof. & & 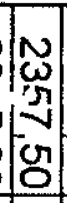 & & & $\begin{array}{l}\omega \\
\omega \\
N \\
\omega \\
0\end{array}$ & $\begin{array}{l}N \\
\omega \\
\omega \\
v \\
o \\
0\end{array}$ & & 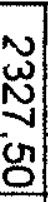 & $\begin{array}{l}\mathrm{N} \\
\mathbf{w} \\
\mathrm{N} \\
\mathrm{v} \\
\mathrm{o}\end{array}$ & $\begin{array}{l}N \\
\omega \\
\vec{v} \\
\mathcal{g}\end{array}$ & $\begin{array}{l}N \\
\omega \\
\vec{N} \\
\dot{O} \\
\end{array}$ & $\begin{array}{c}N \\
0 \\
0 \\
-0 \\
0\end{array}$ & 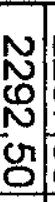 & 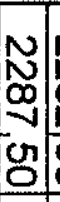 & \begin{tabular}{l}
$N$ \\
$N$ \\
$N$ \\
\hdashline \\
$O$
\end{tabular} & & & & \\
\hline Ambitisporites avitus-dilatus & & $\mathbf{x}$ & $\mathbf{x}$ & $x$ & & $x$ & $x$ & $x$ & $x$ & $x$ & $\mathrm{x}$ & $x$ & $\mathbf{x}$ & $x$ & $\mathbf{x}$ & $x$ & & $\mathrm{x}$ & \\
\hline Ambitisporites tripapillatus & $x$ & $x$ & $\mathbf{x}$ & $x$ & $x$ & & $x$ & $\mathbf{x}$ & & & $x$ & & & $x$ & & & & & \\
\hline Ambitisporites sp. & $x$ & & & & & & & & & & & & & & & & & & \\
\hline Amicosporites sp. & & & & $x$ & & & & & & & & & & & & & & & \\
\hline Aneurospora sp. & $x$ & & & & & & & & & & & & & & & & & & \\
\hline Apiculiretusispora pilicata & & & & & & & & & & & $\underline{x}$ & & & & $\mathbf{x}$ & & & $x$ & \\
\hline Apiculiretusispora pygmea & & & & & & & & & & & & & & & & $x$ & & & \\
\hline Apiculiretusispora $\mathrm{sp}$. & & & & & & & & & & & $x$ & & & & & & & & \\
\hline Aneurospora cf. tojoides var. B & & & & & & & & & & & & & & & & & & $x$ & \\
\hline Aneurospora cf. tojoides var. C & & & & & & & & & & & & & & & & & & $\mathbf{x}$ & \\
\hline Archaeozonotriletes chulus & & $x$ & & & & & & $x$ & & & & & & & & & & & \\
\hline Cymbosporites multiconus & & & & $\underline{x}$ & & & & & & & & & & & & & & & \\
\hline Cymbosporites dammamensis & & & & $x$ & & & & & $x$ & & & & & & & & & & \\
\hline Cymbosporites ssp. & & & & & $x^{\star}$ & & & & & & & $x$ & $\mathrm{x}$ & & & & & & \\
\hline Cymbosporites proteus & & & & & & & & & & $\mathrm{x}$ & $\mathbf{x}$ & & & & & & & & \\
\hline Camptozonotriletes macrospinosus & & & & & & & & & & & & & $x$ & $x$ & & & & $x$ & \\
\hline Dyadospora murusdensa & $x$ & $x$ & & & $x$ & & & & & & $\mathbf{x}$ & & & & & & & & \\
\hline Dictyotriletes cf. emsiensis & & & & & & & & & & & & & & & & & & $x$ & \\
\hline Didolisporites ssp. & & & & & & & & $x$ & & & & & & & & $x$ & & & \\
\hline Didolisporites cf. efeliensis & & & & & & & & & & & & & $\mathrm{x}$ & & & & & & \\
\hline Didolisporites echinaceus & & & & & & & & & & & & & & $x$ & & & & $x$ & \\
\hline Didolisporites efeliensis & & & & & & & & & & & & & & & $x$ & $\mathbf{x}$ & & . & \\
\hline Emphanisporites rotatus & $x$ & $x$ & $x$ & $x$ & $x$ & $\mathbf{x}$ & & & $x$ & $\mathbf{x}$ & $\mathbf{x}$ & $x$ & $\mathbf{x}$ & & & $x$ & & $x$ & \\
\hline Emphanisporites neglectus & & & $\mathrm{x}$ & & & & & & & & & & & & & & & & \\
\hline Emphanisporites novelus & & & & & & & & & & & $\mathbf{x}$ & & & & & & & & \\
\hline Laevolancis divellomedium & $x$ & $x$ & & & $x$ & & & & & & & & & & & & & & \\
\hline Quadrisporites ssp. & $x$ & $x$ & & & & & & & & & $x$ & & & & & & & & \\
\hline Quadrisporites granulatus & $x$ & & & & & & & & & & & & & & & & & & \\
\hline Retusotriletes ssp. & $x$ & $x$ & $x$ & $x$ & & & & & $x$ & & $\mathbf{x}$ & $x$ & $x$ & $x$ & $x$ & $x$ & $\mathrm{x}$ & $x$ & \\
\hline Retusotriletes maculatus & & & & $x$ & & & & & & & & & & & & & & & \\
\hline Perotniletes cf. laevigatus & & & & & & & & & & & & $x$ & & & & & & & \\
\hline Synorisporites papillensis & & & & & $x$ & & $\mathbf{x}$ & $\mathbf{x}$ & $x$ & & $\mathbf{x}$ & $x$ & $\mathbf{x}$ & & & $x$ & $\mathbf{x}$ & $x$ & \\
\hline Synorisporites verrucatus & & $x$ & & & & & & & & & & & & & \multicolumn{3}{|c|}{$\mathrm{x}^{\star \star \star}$} & & \\
\hline Tetrahedraletes medinensis & $x$ & $x$ & & & & & & & & & $\mathrm{x}$ & $x$ & & $\mathrm{x}$ & & & & & \\
\hline Triquitites sp. & & & & & $x^{*}$ & & & & & & & & & & & & & & \\
\hline Zonotriletes ssp. & & & $x$ & & & & & & & & & & & & $x$ & & & $x$ & \\
\hline & & & & & & & & & & & & & & & & & & & \\
\hline * Contaminaçäo / $X^{\star \star}$ - Cf. & & & & & & & & & & & & & & & & & & & \\
\hline
\end{tabular}

Tabela 5 - Esporos e Cryptosporos identificados no poço Assunção I, no intervalo entre 2365 e 2267,5 metros. 
palinológica corresponde às Zonas Z e E de Steemans et. al. (1996). Esta assembléia indica uma idade Lochkoviana / Praguiana para este intervalo.

Para o mesmo intervalo, o biozoneamento com base em quinozoários é menos preciso. Contudo, a presença da espécie Ramochitina magnifica (Grahn' et al., in press, 1999) confirma a idade Praguiana, observada para a parte superior deste último intervalo.

D) - Poço Assunção II

O poço Assunção II foi perfurado próximo ao poço Assunção I, pela companhia petrolífera Pecten em 1982. A perfuração do poço foi interrompida na profundidade de $2925,9 \mathrm{~m}$.

Trinta e sete (37) amostras foram coletadas a partir de sedimentos de calha, em dois diferentes intervalos: a) $2790 \mathrm{~m}$ a $2600 \mathrm{~m}$ e b) $2400 \mathrm{~m}$ a $2300 \mathrm{~m}$. De todas as amostras preparadas 22 lâminas foram estudadas (Tabela 6 ).

A assembléia de miosporos observada neste poço é composta, em ambos intervalos, por gêneros associados a sedimentos de idade Devoniano superior ou mais jovens. Há uma ocorrência freqüente de Grandispora $s p$., Samarisporites sp., Aneurospora sp., Cymbosporites sp., Emphanisporites annulatus, etc.

Os resultados preliminares obtidos neste poço indicam para o primeiro intervalo (a), provavelmente, uma idade Neo-Emsiano e para o segundo (b) uma idade variando entre o Meso - Neo-Devoniano. Entretanto, este resultado é muito diferente dos alcançados em análises prévias realizadas neste poço. Existe a possibilidade de contaminação por desabamento, mas a 


\begin{tabular}{|c|c|c|c|}
\hline Pró. & Lâmina & Prof. & Lâmina \\
\hline 7xnก & $x$ & 2625 & 51391 \\
\hline 2302,5 & 51442 & 2630 & $\mathbf{x}$ \\
\hline 2305 & $x$ & 2635 & $x$ \\
\hline 2307,5 & 51441 & 2640 & $x$ \\
\hline 2310 & $x$ & 2645 & $\mathbf{x}$ \\
\hline 2312,5 & 51440 & 2650 & 51390 \\
\hline 2315 & $x$ & 2655 & 51389 \\
\hline 2320 & 51439 & 2660 & $x$ \\
\hline 2325 & 51430 & 2665 & 51388 \\
\hline 2330 & $x$ & 2695 & $x$ \\
\hline 2332,5 & 51429 & 2700 & $x$ \\
\hline 2342,5 & $x$ & 2705 & 51387 \\
\hline 2347,5 & 51428 & 2710 & 51386 \\
\hline 2350 & $x$ & 2715 & 51385 \\
\hline 2355 & 51427 & 2725 & 51384 \\
\hline 2360 & 51426 & 2735 & 51383 \\
\hline 2365 & 51425 & 2740 & $x$ \\
\hline 2370 & 51424 & 2745 & 51382 \\
\hline 2375 & 51423 & 2750 & 51381 \\
\hline 2380 & 51398 & 2755 & 51380 \\
\hline 2385 & 51397 & 2760 & 51379 \\
\hline 2390 & $\mathbf{x}$ & 2765 & 51378 \\
\hline 2395 & 51396 & 2777,5 & $x$ \\
\hline 2400 & $\mathbf{x}$ & 2780 & 51377 \\
\hline 2600 & 51395 & 2782,5 & 51376 \\
\hline 2605 & $x$ & 2785 & 51375 \\
\hline 2610 & 51394 & 2787,5 & 51374 \\
\hline 2615 & 51393 & 2790 & $x$ \\
\hline 2620 & 51392 & & \\
\hline
\end{tabular}

Tabela 6 - Lâminas preparadas a partir de amostras coletadas no poço Assunção II. 
assembléia palınológica apresenta uma regular evolução ao longo de 500 metros.

Essas idades foram em parte confirmadas pelo $\mathrm{Dr}$. Stanislas Loboziack (comunicação escrita), após o estudo realizado em oito lâminas coletadas entre 2787,50 a 2302,50, o qual indicou uma idade Eo-Efeliana para todo o intervalo" estudado.

Os estudos preliminares realizados nos intervalos amostrados no poço AS-II, visando um fatiamento bioestratigráfico com base em acritarcos e quitinozoas, de maneira geral confirmam uma idade Meso-Devoniana para o intervalo estudado. No entanto, em função das amostras estudadas terem sido coletadas a partir de material de calha, pode existir a possibilidade de contaminação por desabamento.

As idades obtidas para os sedimentos implica em uma total reformulação nas correlações prévias estabelecidas até então entre os poços AS-1 e AS-II.

\subsubsection{2 - Amostras provenientes do Brasil}

As amostras provenientes do Brasil foram coletadas a partir de poços da Petrobrás e de afloramentos localizados na parte norte da Bacia do Paraná. Quarenta e oito (48) amostras foram tratadas e vinte (20) lâminas foram estudadas (Tabela 7). Estas lâminas foram obtidas de amostras provenientes de sedimentos associados às formações Vila Maria, Furnas e Ponta Grossa. 


\begin{tabular}{|c|c|c|c|c|}
\hline Poço & Prof. & Lâmina & Afloramento & Lâmina \\
\hline $3-C B-3-S P$ & 4899 & 51485 & E3 P.1-Am2 & 51630 \\
\hline 3-CB-3-SP & 4902 & 51486 & E3 P.4-Am 5 & $51681 / 51694$ \\
\hline 3-CB-3-SP & 4947 & 51487 & E3 P.10-Am6c & 51631 \\
\hline 3-CB-3-SP & 4950 & 51488 & E9 P. 4-Am1 & 51633 \\
\hline 2-CG-1-MT & 2508 & 51489 & E9P.11-Am3 & $51680 / 51693$ \\
\hline 2-CG-1-MT & 2511 & 51490 & E3 P. 11-Am7 & 51632 \\
\hline 2-CG-1-MT & 2517 & 51491 & E9 P. 39-Am1b & $51675 / 51689$ \\
\hline $2-C G-1-M T$ & 2520 & 51492 & E9 P.41-Am1d & 51676 \\
\hline 2-RA-1-MS & 2970 & 51531 & E9 P.41-Am1e & $51677 / 51690$ \\
\hline 2-RA-1-MS & 2994 & 51532 & E9 P. 45-Am1 & $51678 / 51691$ \\
\hline 2-RA-1-MS & 3423 & 51533 & E9 P. 47-Am1 & $51679 / 51692$ \\
\hline 2-AG-1-MT & $\# 16(1 / 3)$ & 51626 & & \\
\hline 2-AG-1-MT & $\# 16(2 / 3)$ & 51627 & & \\
\hline 2-AG-1-MT & $\# 22(1800)$ & $51695 / 51682$ & & \\
\hline 2-LA-1-SP & $\# 13(3882)$ & 51628 & & \\
\hline 2-LA-1-SP & $\# 13(3900)$ & 51629 & & \\
\hline 2-LA-1-SP & 3924 & 51534 & & \\
\hline 2-LA-1-SP & 3939 & 51535 & & \\
\hline 2-LA-1-SP & 3951 & $51536 / 51539$ & & \\
\hline 2-LA-1-SP & 4017 & 51537 & & \\
\hline 2-DO-1-MT & 3873 & 51538 & & \\
\hline 2-DO-1-MT & 3876 & 51580 & & \\
\hline 2-DO-1-MT & 3879 & 51581 & & \\
\hline $2-A R-1-S P$ & $2949 / 2958$ & 51582 & & \\
\hline 2-AR-1-SP & 3249 & 51583 & & \\
\hline 2-AR-1-SP & 3252 & 51584 & & \\
\hline 2-TL-1-MT & 4497 & 51585 & & \\
\hline 2-TL-1-MT & 4500 & 51586 & & \\
\hline 2-TL-1-MT & 4551 & 51587 & & \\
\hline 2-AN-1-PR & 5346 & 51602 & & \\
\hline 2-AN-1-PR & 5361 & 51603 & & \\
\hline 2-AN-1-PR & 5364 & 51604 & & \\
\hline 2-AN-1-PR & 5508 & 51605 & & \\
\hline 2-R|-1-PR & 4815 & 51606 & & \\
\hline 2-RI-1-PR & 4821 & 51607 & & \\
\hline 2-RI-1-PR & 5274 & 51608 & & \\
\hline 2-JA-1-GO & $\# 36(2030,00)$ & 51609 & & \\
\hline & & & & \\
\hline
\end{tabular}

Tabela 7 - Lâminas preparadas a partir de amostras coletadas em poços e afloramentos, localizadas na parte brasileira da Bacia do Paraná. 


\subsubsection{1 - Amostras de Poços}

A) Poço 2-TL-1-MT

O poço 2-TL-1-MT foi perfurado pela Petrobrás em 1963 e está localizado na parte norte da Bacia do Paraná.

Três lâminas deste poço foram estudadas. As amostras tratadas foram coletadas nos sedimentos de calha associados à Formação Furnas. Entretanto, existe dúvida se os sedimentos estão efetivamente associados a esta formação ou se os mesmos estão relacionados à Formação Vila Maria.

$\mathrm{Na}$ lâmina preparada a partir da amostra coletada na profundidade de $4551 \mathrm{~m}$ foram identificadas somente três espécies de cryptosporos: Tetrahedraletes medinensis, Dyadospora murusdensa e Laevolancis divellomedium.

Uma similar assembléia foi descrita para a profundidade de $4500 \mathrm{~m}$ : Tetrahedraletes medinensis, Dyadospora murusattenuata e Velatitetras laevigata. A outra lâmina estudada foi coletada na profundidade de $4497 \mathrm{~m}$. Nesta lâmina foram registradas 04 espécies de cryptosporos: Tetrahedraletes medinensis, Dyadospora murusdensa, Velatitetras laevigata e Segestreespora laevigata. Somente um espécimen de miosporo (Synosporites $s p$.) foi encontrado nesta lâmina, contudo existe dúvida em sua identificação.

A assembléia identificada não permite uma acurada definição da idade dos sedimentos, mas indica um intervalo de idade entre o Neo-Ashgilliano ao Llandoveriano. 
B) Poço 2-RI-1-PR

O poço 2-RI-1-PR foi perfurado pela Paulipetro em 1982 e está localizado na parte sul da Bacia do Paraná.

Três lâminas deste poço foram analisadas, sendo que as mesmas foram preparadas a partir de sedimentos de calha associados à sucessão sedimentar Pré-Furnas e à Formação Ponta Grossa.

$\mathrm{Na}$ lâmina coletada junto aos sedimentos pré-Furnas, na profundidade de $5274 \mathrm{~m}$, foram encontrados 05 espécies de cryptosporos: Tetrahedraletes medinensis, Laevolancis divellomedium, Quadrisporites granulatus, Rimosotetras problematica e Velatitetras laevigata. Estes elementos indicam uma idade Neo-Ashgilliana a Llandoveriana.

As duas outras lâminas foram preparadas a partir de sedimentos coletados nas profundidades $4821 \mathrm{~m}$ e $4815 \mathrm{~m}$. Na lâmina $4821 \mathrm{~m}$ foram descritas as seguintes espécies: Apiculoretusispora sp., Synorisporites papillensis, Aneurospora isidori, cf. Synorisporites sp., Quadrisporites $s p$. e formas triletes. Na lâmina preparada a partir de sedimentos coletados seis metros acima da posição anterior, foi observada uma assembléia mais diversificada composta pelos seguintes elementos: Retusotriletes sp., Cymbosporites echinaceous, Cymbosporites sp., Synorisporites sp., Apiculiretusispora sp., knoxisporites ?rionde, Emphanisporites rotatus, cf. Emphanisporites perfilum e Quadrisporites $s p$.. Estas duas assembléias indicam uma idade Lochkoviana para os sedimentos.

C) Poço 2-RA-1-MS

O poço 2-RA-1-MS foi perfurado pela Petrobrás em 1981 e está localizado na parte norte da Bacia do Paraná. Três lâminas foram estudadas a 
partir de amostras de calha coletadas em sedimentos associados às formações Furnas e Ponta Grossa.

$\mathrm{Na}$ lâmina preparada a partir de sedimentos originalmente atribuidos à Formação Furnas, na profundidade de $3423 \mathrm{~m}$, doze (12) diferentes espécies de miosporos e cryptosporos foram identificados. Nove espécies de miosporos foram descritas: Ambitisporites sp., Aneurospora sp, Emphanisporites mcgregorii, Aneurospora tojoides, Cymbosporites cf. parisii, Cymbosporites sp., Chelinospora $s p$. ., cf. Anapiculiretusispora sp. e outros miosporos zonados e ornamentados. Foram também descritos três gêneros de cryptosporos: cf. Laevolancis divellomedium, Velatitetras laevigata e Dyadospora murusdensa. Esta assembléia permite a definição de um intervalo de idade que varia do Lochkoviano ao mesoDevoniano.

A assembléia registrada nas duas outras lâminas, obtidas de sedimentos coletados nas profundidades de $2994 \mathrm{~m}$ e $2970 \mathrm{~m}$, é similar à observada na lâmina anterior. Estes resultados não permitem a definição de uma idade mais acurada, como também não excluem a possibilidade de contaminação por desabamento para a lâmina obtida na profundidade de $3423 \mathrm{~m}$.

\section{D) Poço 2-AR-1-SP}

Duas amostras do poço 2-AR-1-SP foram estudadas. Nestas amostras, posicionadas em 3252 metros e 3249 metros, foi identificada uma assembléia palinológica associada ao Neo-Devoniano. Mais precisamente na amostra coletada em 3249 metros foi observada a espécie Retispora lepidophyta, que indica uma idade Neo-Fameniana. Contudo, nestas amostras são também encontrados elementos mais velhos (acritarcos), aparentemente silurianos, demonstrando uma mistura de formas. Assim, como os elementos analisados foram obtidos a partir de amostras de calha, esta mistura de formas pode estar 
associada a uma contaminação por desabamento ou por retrabalhamento $(N$. Maziane, inf. escrita).

Milani et al. (1995) descrevem a presença de acritarcos silurianos, neste poço, no intervalo entre 3319 a 3360 metros. A partir desta informação, os autores associaram estes sedimentos à base da Formação Vila Maria, que estaria no poço em contato com a Formação Alto Garças. Em função do registro de novas ocorrências de acritarcos silurianos, em níveis estratigraficamente acima dos anteriormente assinalados e em associação com formas mais jovens, teriamos então que desenvolver duas novas hipóteses: 1) Os sedimentos de idade siluriana, associados à Formação Vila Maria, se estenderiam até níveis mais rasos do poço e as formas mais jovens ocorreriam em função de uma contaminação por desabamento ou 2) teríamos no poço o registro de sedimentos associados a depósitos mais jovens de idade "struniana" (retrabalhamento), como observado Loboziack et al. (1995) em outras posições da bacia.

E) Poços 2-LA-1-SP; 2-CG-1-MT; 2-AG-1-MT e 2-JA-1-Go

A partir destes poços foram preparadas 12 lâminas, sendo estudadas aquelas relacionadas à Formação Furnas. Os resultados obtidos não foram satisfatórios, uma vez que as lâminas apresentaram raros fragmentos de matéria orgânica. No entanto, a lâmina de número 51537, preparada a partir da profundidade de 4017 metros, no poço 2-LA-1-SP, demonstrou uma abundância de elementos palinológicos de idade Devoniana. Contudo, por se constituir de uma amostra de calha, existe a possibilidade de contaminação por desabamento, a partir de niveis mais jovens superiores. 


\subsubsection{2 - Amostras de Afloramentos}

Onze amostras coletadas em afloramentos foram preparadas (Tabela 7). Todos os afloramentos amostrados estão localizados na parte norte da Bacia do Paraná. Estas amostras foram coletadas a partir de sedimentos associados às formações Vila Maria, Furnas e Ponta Grossa. Todas as lâminas obtidas a partir de sedimentos associados à Formação Vila Maria foram estudadas.

Infelizmente, nestas lâminas há pouca matéria orgânica preservada. Com relação aos cryptosporos, em uma única lâmina obtida a partir de sedimentos coletados na localidade E9 P.47 - Am. 01 (Ribeirão das Perdizes), foi possivel identificar maior diversidade de elementos: Tetrahedraletes medinensis, Rimosotetras problemática, Velatitetras rugosa e Velatitetras $s p$.

Nas demais lâminas raros espécimens de cryptosporos foram encontrados. Entretanto, em algumas lâminas foram observados fragmentos de acritarcos e quitinozoas. Contudo, o estudo destes fragmentos em associação com os cryptosporos não auxiliaram na definição da idade dos sedimentos.

Foram obtidos, também, resultados satisfatórios para algumas amostras coletadas junto à Formação Ponta Grossa.

\section{A) Cachoeira das Perdizes (Fm Vila Maria)}

Neste afloramento pode ser observada uma seção sedimentar completa associada à Formação Vila Maria. Para o estudo bioestratigráfico foram coletadas amostras em diamictitos e siltitos / folhelhos presentes na seção. Este afloramento foi inicialmente estudado, em termos palinológicos, por Laranjeiras et al. (1997). A assembléia palinológica diagnosticada por esses autores indicou uma idade eossiluriana (Landoveriano inferior a médio: Rhudaniano a Aeroniano) para 
os sedimentos innos. A revisão realizada no material estudado por esses autores mostrou a existência de uma abundante diversidade de criptosporos e a ausência de esporos triletes verdadeiros. Este fato indica uma idade mais antiga para os sedimentos finos desta localidade, ou seja, uma idade Eo-Llandoveriano (Neohirnantiano a Eo-aeroniano).

Neste mesmo afloramento, a assembléia diagnosticada no diamictito (Amostra: E9 P.47 - Am. 01): Tetrahedraletes medinensis, Rimosotetras problemática, Velatitetras rugosa e Velatitetras $s p$, demonstra uma grande similaridade com aquela observada nos sedimentos finos, posicionados imediatamente acima dos diamictitos. Assim, as idades observadas, tanto para o diamictito quanto para os sedimentos finos estão muito próximas, variando entre 0 Neo-ordoviciano e o Eossiluriano.

B) Rodovia GO-174, Km 148 (Formação Ponta Grossa)

Neste afloramento foram coletadas amostras junto a base da Formação Ponta Grossa, mais precisamente a um metro do contato entre as Formações Furnas e Ponta Grossa. Esta superfície de contato é marcada por um nivel conglomerático pouco espesso, de caráter local (vide: Pereira, 1992). Os elementos encontrados em uma das lâminas permite definir uma idade Praguiana para a base da Formação Ponta Grossa, principalmente em função da presença de espécie Ramochitina magnifica, um quitinozoa utilizado como guia deste intervalo no Gondowana Ocidental. 
C) Rodovia GO-174, Km 126 (E3P1-Am2a) (Formação Ponta Grossa)

Nesta localidade foi coletada uma amostra a partir de folhelhos I siltitos oxidados, associados à Formação Ponta Grossa. Aparentemente, este conjunto de sedimentos encontra-se em contato por falha com um pacote composto por arenitos grossos de cor vermelha, associados ao Membro Médio da Formação Ponta Grossa.

A lâmina estudada (n. ${ }^{\circ}$ 51630) apresentou inúmeros elementos palinológicos, tais como: Synorisporites cf. verrucatus, Synorisporites tripapillatus, Poleyedryxium fragorulum; que permitiram definir uma idade Meso a NeoPraguiana para estes sedimentos.

\subsection{4 - Resultados Bioestratigráficos Gerais}

Os resultados obtidos a partir das amostras paraguaias permitem a definição de uma divisão bioestratigráfica geral para os sedimentos do EoPaleozóico. Pela primeira vez, foram registrados sedimentos de idade EoDevoniana no Paraguai. A mesma situação ocorre para os sedimentos de idade Neo-Ordoviciana. Estes sedimentos são, normalmente, descritos para a região, mas só agora existem realmente elementos que provam esta idade.

Este novo arcabouço bioestratigráfico possibilita a realização de correlações estratigráficas mais seguras entre os diferentes poços e afloramentos no Paraguai, com os dados obtidos nos países vizinhos. Esta situação é bastante importante porque o controle estrutural sobre o registro sedimentar é intenso. Normalmente, é extremamente difícil definir a posição estratigráfica de diferentes sedimentos observados nos afloramentos e poços porque os aspectos faciológicos são similares e há um forte controle por falhas. 
Os dados obtidos a partir das amostras brasileiras contribuem para um melhor esclarecimento das idades dos sedimentos associados às sucessões sedimentares silurianas e eo-devonianas. Estes resultados preliminares mostram que existe uma assembléia similar de cryptosporos para o Eo-Siluriano da Bacia do Paraná. Novas investigações sobre os sedimentos silurianos são necessárias para melhor esclarecer as relações estratigráficas entre os diferentes registros da Formação Vila Maria no Brasil e os sedimentos de mesma idade no Paraguai. Os resultados também sugerem que a idade dos sedimentos associados à parte inferior da Formação Ponta Grossa, na parte oeste da Bacia do Paraná, são provavelmente de idade Lochkoviana, ficando mais jovem para leste onde a mesma é Praguiana.

De forma geral, os dados palinológicos obtidos a partir dos poços e afloramentos, tanto na área brasileira como no Paraguai, possibilitaram atingir os objetivos inicialmente traçados nesta pesquisa, referente à elaboração de um refinamento biostratigráfico para o intervalo. Os novos dados obtidos, sobretudo no Paraguai, geraram um grande avanço na redefinição do empilhamento estratigráfico, além de permitir uma melhor caracterização dos elementos constituintes das biozonas identificadas para este intervalo de tempo. No Brasil, os dados bioestratigráficos possibilitaram uma contribuição importante no esclarecimento de pontos polêmicos relativos à identificação dos sedimentos de idade Siluriana, bem como na melhor definição da idade dos sedimentos envolvidos na histórica questão do contato Furnas-Ponta Grossa. De forma acoplada a este estudo bioestratigráfico, foi realizada uma análise geoquímica detalhada de alguns afloramentos e furos de sondagem (apresentada no capítulo 3). Os dados finais obtidos desta análise foram bastante efetivos na definição das principais superfícies de inundação observadas na bacia. 


\section{4 - Dados Geocronológicos}

\subsection{1 - Introdução}

A datação de rochas pelíticas através da utilização de métodos radiométricos vem sendo desenvolvida há cerca de três décadas em todo o mundo, por várias equipes de pesquisa. Contudo, este mecanismo de datação não é amplamente aceito na literatura, em decorrência dos inúmeros condicionantes teóricos e metodológicos que são necessários para a aplicação dos mesmos.

Como salienta Clauer (1979), é provável que a descrença na datação de rochas sedimentares esteja relacionada ao fato de que várias datações foram estabelecidas para rocha total; outros estudos foram realizados sem um rígido controle mineralógico e também porque a história metamórfica dos sedimentos, na maioria das vezes, não era conhecida ou foi desprezada.

As rochas sedimentares são compostas por minerais detríticos e por minerais autigênicos. Assim, a datação de rocha total pode produzir um dado referente à área fonte, em função dos detríticos, caso não tenha ocorrido uma homogeneização isotópica ou, como prefere Mizusaki (1992), uma uniformização da razão isotópica inicial. Essa uniformização é função do ambiente de sedimentação, estando a mesma condicionada pela presença de fluídos intersticiais e pela presença de minerais abertos com alta capacidade de troca catiônica (CTC), bem como pode ser influenciada também pelo método de coleta.

Esses minerais, normalmente representados por alguns argilominerais, concentram-se nas frações mais finas, abaixo de 2 micras. Os mesmos, contudo, são suscetíveis às alteraçōes termais e as variações químicas decorrentes do processo de evolução diagenética da rocha, que pode culminar com o início do metamorfismo de baixo grau. Esta evolução pode causar a 
abertura da estrutura do mineral, fato que poderá alterar sua razão isotópica inicial.

Assim, a datação de rochas sedimentares é um campo de trabalho que requer o estabelecimento de premissas básicas, envolvendo as condições iniciais de homögeneização isotópica, o padrão de amostragem e a evolução mineralógica dos argilominerais, para se obter resultados pertinentes com a história evolutiva dos sedimentos analisados.

\subsection{2 - Métodos de Datação Radiométricas}

\subsubsection{1 - Premissas Básicas}

A utilização de métodos radiométricos visando a datação geocronológica é aplicada partindo-se da premissa de que em algum momento os minerais que compõem a rocha foram submetidos a um evento que fechou o sistema isotópico, assegurando uma razão isotópica inicial homogênea para toda a rocha.

Para as rochas ígneas, as trocas químicas desenvolvidas na fase líquida possibilita uma razão isotópica homogênea, quando da cristalização dos minerais. Para as rochas metamórficas, os eventos térmicos e de pressão a quais as mesmas são submetidas geram uma homogeneização isotópica por difusão no estado sólido, como salienta Thomaz Filho \& Lima (1981).

No caso de rochas sedimentares esta homogeneização inicial irá envolver minerais detríticos de granulometria variada, que herdaram razões isotópicas de áreas fontes distintas entre si, depositados em um ambiente que possui uma determinada composição isotópica. Assim, se o objetivo do estudo é o de datar a idade de uma determinada sedimentação, e não os eventos 
diagenéticos ou metamórficos, há a necessidade de se utilizar o conceito de dispersão mecânica em meio aquoso elaborado por Cordani et al. (1978).

Este conceito admite que em um mesmo ambiente de sedimentação a dispersão mecânica do material detrítico produzirá uma uniformização das razões isotópicäs do estrôncio, considerando-se amostras de rocha total de pequenas dimensões. O mesmo baseia-se ainda na possibilidade de ocorrer trocas químicas entre as frações mais finas e o meio deposicional (Thomaz Filho \& Lima,1981; Cordani et al., 1985).

Este modelo de homogeneização é admitido por Misuzaki (1992). Contudo, a autora apresenta alguns condicionantes para o mesmo, como: 1) as características do ambiente de sedimentação, considerando os ambientes com influências marinhas os mais favoráveis, devido a maior facilidade de trocas químicas por percolações de fluidos; 2) a presença de argilo-minerais abertos, na fração granulométrica menor que duas micras e 3) a realização de uma coleta sistemática das amostras a serem datadas, levando-se em conta um pequeno espaçamento entre as mesmas. Sob tais condições, a uniformização ocorrerá no momento imediatamente após a sedimentação, ainda na fase da diagênese precoce.

Bonhomme (1987) sugere que se as argilas transformam-se, recristalizam-se, ou cristalizam-se durante os processos sedimentares contemporâneos à deposição, elas irão adquirir um novo equilíbrio isotópico $(\mathrm{Rb} / \mathrm{Sr})$ ou irão liberar o seu $\mathrm{Ar}$ radiogênico herdado. Esta reorganização possibilitará, então, a determinação de uma idade estratigráfica. Contudo, como salienta este autor, as condições para que tal situação ocorra são muito específicas, sendo raramente satisfeitas.

Após o momento da deposição, atuam sobre os sedimentos eventos no campo da diagênese e do metamorfismo que afetam os minerais de argila. 
Assim, estes eventos são passiveis de datação, uma vez que poderá ocorrer uma reorganização isotópica desses minerais, que foram transformados ou neoformados em decorrência desses eventos. Contudo, a definição do limite entre os campos da diagênese e do metamorfismo não é clara, sendo necessário, para melhor defini-la, a utilização de metodologias que levem em consideração a relação entre ä evolução dos argilominerais com a intensidade dos processos termodinâmicos.

Dessa forma, sob condições adequadas, é possível a utilização das metodologias de $\mathrm{Rb} / \mathrm{Sr}$ e K/Ar para a datação do momento da deposição dos eventos diagenéticos e da atuação do metamorfismo.

\subsubsection{2 - Definição do Limite Diagênese - Metamorfismo}

Como visto, a datação radiométrica de rochas sedimentares pode auxiliar no estabelecimento da evolução de um determinado conjunto sedimentar, desde o momento da deposição dos sedimentos até o início da atuação dos eventos metamórficos. Nesse sentido, é possível definir o campo da diagênese e do metamorfismo. Contudo, como discutido por vários autores (Dunoyer de Segonzac, 1970; Kisch,1983 e Frey \& Kisch,1987), não é possível estabelecer um limite nítido entre os processos diagenéticos e metamórficos. Como salienta Kisch (1983), o incremento das condições de temperatura e pressão é o responsável pela instabilidade dos minerais. As reações químicas decorrentes que governam o restabelecimento do equilíbrio entre as diversas fases minerais e entre estas e o ambiente, ocorrem tanto no campo diagenético como no campo metamórfico.

A diagênese foi definida como um conceito geológico por Walther (1893-1894; apud Kisch,1983) para incorporar "... todas aquelas variações físicas e químicas a que uma rocha é submetida após a sua deposição, sem a intervenção de compressão orogênica e calor vulcânico". 
Existe na literatura um amplo espectro de definições que tentam estabelecer um conjunto de fases diagenéticas que marcam a evolução da diagênese até o campo do metamorfismo. Dunoyer de Segonzac (1970) propôs um modelo de evolução (Tabela 8), com base nos argilominerais, que apresenta uma razoável correlação com o modelo de evolução diagenética elaborado por autores russos, que leva em consideração estágios de modificações texturais dos sedimentos detríticos.

\begin{tabular}{|c|c|}
\hline $\begin{array}{c}\text { Estágios da Evolução Diagenética } \\
\text { segundo Dunoyer de Segonzac (1970) }\end{array}$ & $\begin{array}{c}\text { Modelo de Evolução Diagnética segundo } \\
\text { autores russos }\end{array}$ \\
\hline Diagênese Inicial & Diagênese \\
\hline Diagênese Intermediária & Catagenesis inicial \\
\hline Diagênese Tardia & Catagenesis tardia \\
\hline Anquizona & Metagenesis \\
\hline
\end{tabular}

Tabela 8 - Estágios da evolução diagenética

Kubler (1964) introduziu o conceito da existência de uma zona anquimetamórfica (ou anquizona), intermediária entre a zona de diagênese tardia e a epizona do metamorfismo regional (incluído a fácies xisto verde). Esta zona anquimetamórfica foi definida com base nos valores de cristalinidade das illitas. Este método é utilizado como um dos principais indicadores do grau metamórfico e está baseado na medição do índice de cristalinidade da illita (IC), que foi proposto por Kubler $(1964,1968)$ para caracterizar o aumento da cristalinidade desde a diagênese até o metamorfismo de baixo grau, em rochas sedimentares clásticas, monitorado pelo decréscimo na largura do pico de difração de Raio $X$ de 10A, medido na metade de sua altura (Índice de Kubler). 
Segundo Robinson et al. (1990), acredita-se que o fator dominante no incremento da cristalinidade é a temperatura, embora, como ressaltado por estes autores, outros fatores podem influenciar como:(1) pressão de fluido, (2) stress, (3) litologia, (4) composição química [incremento de $\mathrm{K}$ ], (5) mineralogia e (6) tempo.

$\mathrm{Na}$ literatura existe um conjunto de técnicas destinadas à medição do índice de cristalinidade. Esta diversidade de métodos experimentais, associada ao fato de ocorrer uma variedade de fatores que controlam o IC, podem produzir resultados distintos, que dificultam a definição exata do limite diagênesemetamorfismo. Toselli \& Weber (1982) apresentam uma tabela comparativa desses limites e ressaltam que para o campo diagenético haveria maior influência do meio externo sobre o IC da illita, em comparação com a zona metamórfica. Nesta, devido a menor influência externa o IC seria um excelente indicador do limite anquimetamórfico e epimetamórfico.

Robinson et al. (1990), após uma detalhada investigação nos erros envolvidos e na precisão do IC, sustentam que este é um método de caráter estatístico (Frey, 1987), pelo qual somente variações gerais no grau metamórfico podem ser definidas.

Durante os estágios mais avançados da diagênese e no campo do metamorfismo inicial, além do progressivo incremento da " $C$ " da illita, ocorre também uma variação nos politípos de illita, onde em função do aumento da temperatura, há uma transformação do politipo $1 \mathrm{Md}$ para 2M1. Assim, sob as mais altas temperaturas, a estrutura $2 \mathrm{M}$ é mais estável, sendo mais freqüente no campo metamórfico. Hunziker et al. (1986) afirmam que dependendo do tamanho do gräo, litologia e composição dos fluídos intersticiais, as micas atingem este estágio polimorfo em torno de $150^{\circ}$ a $300^{\circ} \mathrm{C}$. 
Dunoyer de Segonzac (1970) argumenta que os tipos polimorfos $1 \mathrm{Md}$ e $1 \mathrm{M}$ transformam-se para $2 \mathrm{M}$, sob condições de diagênese profunda e no estágio anquimetamórfico. Dessa forma, segundo o autor, os parâmetros cristalográficos dos polimorfos de illita são suficientemente bem definidos para servirem como escalas no zoneamento dos processos pós-deposicionais até o metamorfismo.

Portanto, a definição de limites rígidos para os processos que atuam sobre os sedimentos nos campos da diagênese e do metamorfismo não é pertinente, uma vez que os mesmos são contínuos e os mecanismos de aferição dos mesmos são feitos por métodos analíticos sujeitos a várias influências. Tal situação poderá causar dificuldades quando da análise dos dados geocronológicos.

\subsection{3 - Influência do Metamorfismo na Datação de Rochas Pelíticas}

\subsubsection{1 - Aspectos Gerais}

A homogeneização isotópica de Estrôncio e Argônio nos sedimentos pelíticos em ambiente de baixo grau metamórfico pode ocorrer envolvendo um grande volume de rocha sedimentar. Conforme Clauer \& Kröner (1979), embora o mecanismo de homogeneização isotópica do estrôncio nas frações menores que 2 (duas) micra não seja totalmente explicado, aparentemente o mesmo ocorre em grande escala nas frações finas que apresentam as mesmas paragêneses.

Segundo Clauer (1976), uma temperatura de aproximadamente $250^{\circ} \mathrm{C}$ e pressões menores que $1 \mathrm{Kbar}$, são provavelmente necessárias para homogeneizar as frações sedimentares argilosas. Contudo, pelos estudos de Clauer \& Kröner (1979), a influência do metamorfismo regional sobre as frações 
finas depenae não só da temperatura e pressão, mas tambem da natureza química do sedimento original.

De maneira geral, as metodologias $\mathrm{Rb} / \mathrm{Sr}$ e $\mathrm{K} / \mathrm{Ar}$ comportam-se de forma similar quando da datação de sedimentos afetados pelo metamorfismo de baixo grau. Bonhomme (1987) sugere, com base em dados dos Alpes Franceses, que em um ambiente metamórfico que progride de condições de catagênese para - campo da fácies xisto verde, os sistemas isotópicos $\mathrm{Rb} / \mathrm{Sr}$ e $\mathrm{K} / \mathrm{Ar}$ modificam-se similarmente como conseqüência da extração de ambos os nuclídeos radiogênicos, em função da variação na intensidade dos eventos termo-tectônicos.

Com base nos dados de Macedo (1982; apud Bonhomme,1987) 0 citado autor argumenta que o sistema isotópico KJAr seria mais sensivel para datar eventos tardios de menor intensidade. Este argumento parece ser contraditório à afirmação de Clauer \& Kröner (1979), que constatam que o sistema $\mathrm{K} / \mathrm{Ar}$ é relativamente mais resistente que o sistema $\mathrm{Rb} / \mathrm{Sr}$, podendo haver em algumas situações apenas a homogeneização deste último.

Hunziker et al. (1986) descrevem em seus estudos que os dados de $\mathrm{Rb} / \mathrm{Sr}$ obtidos a partir de zonas de diagênese tardia e de anquizonas são sistematicamente maiores que os valores correspondentes para KJAr. Segundo estes autores, isto pode ser um reflexo de uma menor ativação energética requerida para afetar a difusão de $40 \mathrm{Ar}$, comparada com a exigida para a difusão de $87 \mathrm{Sr}$. Ainda conforme os citados autores, a uma temperatura de $260+/-30^{\circ} \mathrm{C}$, pode ocorrer uma perda total de Ar por difusão, em função da reorganização da estrutura de illita. Assim, as idades KJAr são progressivamente reduzidas, fato associado a um concomitante decréscimo de $40 \mathrm{Ar}$ e aumento no conteúdo de $\mathrm{K}$.

Ainda segundo Bonhomme (1987), em áreas onde não são registrados efeitos visiveis de atuação metamórfica, poderão ocorrer alterações diagenéticas induzidas por esse metamorfismo, que são passíveis de datação. 


\subsubsection{2 - Metodo Rubídio / Estrôncio}

Como visto, a atuação de condições metamórficas de baixo grau ou mesmo de diagênese profunda sobre os sedimentos pode modificar a razão isotópica inicial. Este fato estará associado a um momento pós-deposicional, gerando uma ñova reorganização isotópica que irá registrar estes eventos. Como já observado, as frações mais finas são mais sensiveis a estes eventos.

Dessa forma, as datações radiométricas obtidas a partir de rochas sedimentares que sofreram a atuação de algum evento termodinâmico devem ser cuidadosamente analisadas, pois podem revelar dados associados tanto ao momento deposicional como a eventos de remobilização.

Seguindo este raciocínio, Cordani et al. (1978) propuseram quatro modelos de interpretação para os diagramas $\mathrm{Rb} / \mathrm{Sr}$ em rochas pelíticas. Estes modelos são exemplos de diagramas isocrônicos, nos quais todas as amostras cogenéticas de rocha total foram sujeitas às condições ideais de uniformização pelo mecanismo de dispersão do material clástico e assim exibem a mesma razão inicial $87 \mathrm{Sr} / 86 \mathrm{Sr}$.

O modelo isocrônico I (Modelo I) caracteriza uma unidade pelítica no qual processos diagenéticos à baixa temperaturas produzem a homogeneização isotópica do estrôncio nas frações mais finas do sistema, em volumes de poucos centímetros cúbicos. No segundo modelo isocrônico (Modelo II), os processos diagenéticos de baixa temperaturas provocam a homogeneização do estrôncio em amostras de rocha total em volumes de poucos centímetros cúbicos.

No modelo isocrônico III (Modelo III), os eventos pós-deposicionais diagenéticos e metamórficos possuem intensidade suficiente para a homogeneizar, em nivel de uma unidade litoestratigráfica, as razőes isotópicas dos argilominerais, alinhando, em uma única isócrona, as frações finas, bem como 
os subsistemas compostos pelos resíduos e lixiviados. O modelo IV (Modelo IV) diferencia-se do modelo anterior pelo alinhamento das amostras de rocha total com as frações mais finas ( $<2$ micra) e os subsistemas, em função da atuação de processos diagenéticos e metamórficos muito intensos, que provocam uma homogeneização total da unidade litoestratigráfica, já no campo do anquimetamorfismo.

Estes modelos foram aplicados para a análise de dados (Cordani et al., 1978; Thomaz Filho \& Lima, 1981; Cordani et al. 1985; entre outros) referentes às coberturas cratônicas brasileiras e depósitos associados ao ciclo brasiliano.

\subsubsection{3 - Considerações gerais sobre a metodologia}

Analisando-se vários artigos que utilizaram-se dessa metodologia para a obtenção de idades radiométricas (Bonhomme, 1976; Clauer, 1976; Brito Neves et al., 1977; Thomaz Filho \& Bonhomme, 1979; Parenti Couto et al., 1982; Bonhomme et al. 1982; Macedo et al., 1984; Bonhomme, 1987) podemos observar que o metamorfismo de baixo grau modifica substancialmente as razões isotópicas iniciais dos sedimentos, promovendo um reequilibrio isotópico que ficará impresso na rocha, sendo que o momento de atuação desse evento de remobilização poderá ser datado pelos métodos $\mathrm{Rb} / \mathrm{Sr}$ e KJAr.

A atuação do metamorfismo ocorre tanto no campo da estruturação química dos argilominerais, como promovendo a modificação das razões isotópicas pela perda ou ganho dos elementos radiogênicos. Embora estas modificações desenvolvam-se, aparentemente, com uma intensidade regulada pelo incremento do metamorfismo, não está claro a possibilidade de se identificar esses sucessivos eventos nas amostras. 
Os dados de idades radiométricas obtıdos a partir de rochas sedimentares devem ser analisados levando-se em consideração os resultados obtidos pela análise mineralógica dos sedimentos, através de estudo do índice de cristalinidade dos argilominerais, bem como suas características de estruturação química.

Para sedimentos pelíticos que sofreram a atuação de eventos de rejuvenescimento isotópico, as frações finas são as mais apropriadas para a datação, pois nas mesmas há uma maior probabilidade de concentrarem-se os argilominerais. Estes são mais facilmente afetados pelos eventos de rejuvenescimento que provocam sua reestruturação.

As amostras de rocha total dos sedimentos possuem uma tendência de alinharem-se com as frações finas, quando os sedimentos são afetados pelo metamorfismo. Por outro lado, no campo da diagênese esse alinhamento não ocorre necessariamente, podendo existir um alinhamento das frações finas indicando um evento de remobilização e uma isócrona de rocha total, que pode ser analisada em termos de uma idade mínima de sedimentação.

Por último, parece que condições de soterramento profundo dos sedimentos, ainda no campo da diagênese, podem provocar transformações nos argilominerais, como modificar razōes isotópicas iniciais, promovendo uma homogeneização isotópica do meio, de forma similar à atuação do metamorfismo.

2.4.4 - Aplicação do método Rubídio/Estrôncio em sedimentos paleozóicos da Bacia do Paraná

A aplicação do método Rb/Sr em sedimentos da Bacia do Paraná foi realizada, de forma pioneira, por Kawashita (1972) e Thomaz Fitho (1976). Os resultados positivos obtidos por estes autores desencadearam um série de 
trabalhos (Thomaz Filho et al., 1976; Cordani et al. 1978 e 1985) que demostraram a real possibilidade da datação radiométrica de materiais pelíticos, em função da obtenção de idades radiométricas, pelo método $\mathrm{Rb}-\mathrm{Sr}$, concordantes com os valores esperados para a época da sedimentação.

Nos últimos anos esta metodologia foi pouco utilizada. Contudo, Mizusaki (1992) por meio de um estudo detalhado do comportamento do Rb e $\mathrm{Sr}$ em sedimentos recentes, demonstrou a existência do fenômeno de uniformização isotópica, premissa básica para o uso do método $\mathrm{Rb} / \mathrm{Sr}$.

$\mathrm{Na}$ Bacia do Paraná ainda persiste alguns problemas com relação a datação relativa de algumas unidades, principalmente naquelas onde as litofácies arenosas são predominantes, como as formações Furnas e lapó. Assim, tentando auxiliar na solução dessa questão, realizamos uma ampla coleta de amostras visando a datação radiométrica de toda a seção sedimentar pré - Formação Ponta Grossa (Tabela 9).

\begin{tabular}{|c|c|c|c|c|c|c|}
\hline AMOSTRAS & QUANTIDADE & ETAPA & LATITUDE & LONGITUDE & UNID. ESTRAT. & LOCAL \\
\hline DR-1-GO & $\overline{A-E}$ & $5^{\circ}$ & $16^{\circ} 47,500^{\prime} \mathrm{S}$ & $51^{\circ} 05,000^{\prime} \mathrm{W}$ & $\begin{array}{c}\text { Formação Pta } \\
\text { Grossa? }\end{array}$ & GO \\
\hline DR-2-GO & $A-E$ & $5^{\circ}$ & $16^{\circ} 28,107^{\prime} \mathrm{S}$ & $52^{\circ} 05,865^{\prime} \mathrm{W}$ & $\begin{array}{l}\text { Formação } \\
\text { Furnas }\end{array}$ & GO \\
\hline DR-3-MT & $A-E$ & $5^{\circ}$ & $15^{\circ} 51,157^{\prime} \mathrm{S}$ & $52^{\circ} 16,357^{\prime} \mathrm{W}$ & $\begin{array}{c}\text { Formação Vila } \\
\text { Maria }\end{array}$ & MT \\
\hline DR-4-MT & $A-E$ & $5^{\circ}$ & $15^{\circ} 19,916^{\prime} \mathrm{S}$ & $52^{\circ} 14,384^{\prime} W$ & Vale dos Sonhos & MT \\
\hline DR-5-MT & $\overline{A-E}$ & $5^{\circ}$ & $13^{\circ} 51,033^{\prime} \mathrm{S}$ & $52^{\circ} 03,013^{\prime} \mathrm{W}$ & $\begin{array}{l}\text { Formação } \\
\text { Diamantino }\end{array}$ & $\overline{M T}$ \\
\hline DR-6-MT & $A-D$ & $7^{\circ}$ & $16^{\circ} 56,979^{\prime} \mathrm{S}$ & $53^{\circ} 05,280^{\prime} \mathrm{W}$ & $\begin{array}{c}\mathrm{Fm} \\
\text { Corumbatai }\end{array}$ & MT \\
\hline DR-7-MT & $A-B$ & $7^{\circ}$ & $16^{\circ} 49,044^{\prime} \mathrm{S}$ & $53^{\circ} 00,746^{\prime} \mathrm{W}$ & Embasamento & MT \\
\hline DR-8-MT & $A-E$ & $7^{\circ}$ & $16^{\circ} 47,517^{\prime} \mathrm{S}$ & $52^{\circ} 58,978^{\prime} W$ & $\begin{array}{c}\text { Formação } \\
\text { Furnas }\end{array}$ & MT \\
\hline DR-9-MT & A & $7^{\circ}$ & $14^{\circ} 53,168^{\prime} \mathrm{S}$ & $52^{\circ} 30,275^{\prime} \mathrm{W}$ & $\begin{array}{c}\text { Formação Vila } \\
\text { Maria }\end{array}$ & $\overline{M T}$ \\
\hline
\end{tabular}




\begin{tabular}{|c|c|c|c|c|c|c|}
\hline E2-P10 & $E-F-H$ & $2^{\circ}$ & $\begin{array}{l}\text { Lachoeira do } \\
\text { Rio São Jorge }\end{array}$ & & $\begin{array}{c}\text { Formação } \\
\text { lapó }\end{array}$ & $P R$ \\
\hline E2-P06 & $A \in B$ & $2^{\circ}$ & $\begin{array}{l}\text { Rod. Castro - } \\
\text { Tibagi }\end{array}$ & & $\begin{array}{c}\text { Formação } \\
\text { lapó }\end{array}$ & $\overline{P R}$ \\
\hline E3-P39 & $15 A-15 B$ & $3^{\circ}$ & $18^{\circ} 57,26^{\prime} \mathrm{S}$ & $54^{\circ} 57,26^{\prime} \mathrm{W}$ & $\begin{array}{c}\text { Fm. Vila } \\
\text { Maria? }\end{array}$ & MS \\
\hline E3 - P10 & $A m .6 A$ & 3 & Amorinópolis & & $\begin{array}{c}\text { Formação Ponta } \\
\text { Grossa }\end{array}$ & GO \\
\hline
\end{tabular}

Tabela 9 - Amostras coletadas visando a datação radiométrica.

As amostras coletadas foram estudadas em colaboração com a Dra. Ana Maria Misuzaki, sendo que as análises foram realizadas em laboratórios da UFRGS e no Laboratório de Geocronologia da USP.

A fração argila (fração menor que 2 micra) de algumas amostras foi analisada por Difração de Raio X (DRX). Os resultados obtidos para as amostras DR-4-MT e DR-5-MT não foram satisfatórios em função da intensa silicificação das mesmas. A maioria das amostras apresentou as seguintes características: um alto teor relativo de caulinita, que pode identificar ação intempérica; uma ausência ou baixos teores de inter-estratificado illita-esmectita e a presença de illita (Tabela 10).

\begin{tabular}{|c|c|c|c|c|c|}
\hline AMOSTRAS & Illita/Esmectita & Illita & Clorita & Caulinita. & Quartzo \\
\hline $\begin{array}{c}\text { DR-1-GO } \\
\text { Am.B }\end{array}$ & $35 \%$ & $25 \%$ & & $40 \%$ & \\
\hline $\begin{array}{c}\text { DR-1-GO } \\
\text { Am.D }\end{array}$ & $27 \%$ & $27 \%$ & & $46 \%$ & \\
\hline $\begin{array}{c}\text { DR-1-GO } \\
\text { Am.E }\end{array}$ & $47 \%$ & $31 \%$ & & $22 \%$ & \\
\hline $\begin{array}{c}\text { DR-2-GO } \\
\text { Am.A }\end{array}$ & & $84 \%$ & & $16 \%$ & \\
\hline $\begin{array}{c}\text { DR-2-GO } \\
\text { Am.B }\end{array}$ & $\operatorname{Tr}$ & $79 \%$ & & $21 \%$ & \\
\hline $\begin{array}{c}\text { DR-2-GO } \\
\text { Am.E }\end{array}$ & $\operatorname{Tr}$ & $73 \%$ & & $27 \%$ & \\
\hline
\end{tabular}




\begin{tabular}{|c|c|c|c|c|c|}
\hline $\begin{array}{c}\text { DR-3-M1 } \\
\text { Am.E }\end{array}$ & $30 \%$ & $42 \%$ & $5 \%$ & $23 \%$ & \\
\hline $\begin{array}{c}\text { E2-P10 } \\
\text { Am.F }\end{array}$ & & $62 \%$ & & $38 \%$ & TR \\
\hline $\begin{array}{c}\text { E2-P06 } \\
\text { Am.A }\end{array}$ & & $54 \%$ & & $46 \%$ & $\mathrm{Tr}$ \\
\hline $\begin{array}{c}\text { E2-P06 } \\
\text { Am.B }\end{array}$ & $\cdots$ & $53 \%$ & & $47 \%$ & $\mathrm{Tr}$ \\
\hline $\begin{array}{c}\text { E3-P39 } \\
\text { Am.15A }\end{array}$ & & $8 \%$ & & $92 \%$ & $\mathrm{Tr}$ \\
\hline $\begin{array}{c}\text { E3-P39 } \\
\text { Am.15B }\end{array}$ & & $8 \%$ & & $92 \%$ & $\mathrm{Tr}$ \\
\hline $\begin{array}{c}\text { E3-P10 } \\
\text { Am.6A }\end{array}$ & $50 \%$ & $42 \%$ & & $8 \%$ & \\
\hline
\end{tabular}

Tabela 10 - Amostras analisadas por DRX.

Das amostras analisadas, foram preparadas as seguintes para a análise isotópica:

Formação lapó: E2-P10, amostras E, F e H

E2 P06, amostras A e B

Formação Vila Maria: $\quad$ DR-3-MT, amostra E

E3-P39, amostras 15A e 15B

Formação Furnas: $\quad$ DR-2-GO, amostras A, B e E

Formação Ponta Grossa: DR-1-GO, amostras B, D e E

E3-P10, amostra 6A

De todo o material estudado, aquele referente à Formação lapó, foi o que gerou a melhor isócrona, com excelente alinhamento, fornecendo um resultado preliminar para a idade de deposição dos sedimentos de 456,4 +/- 6,4 Ma. O material analisado é composto por diamictitos de coloração cinza, de caráter polimítico, com clastos variando entre 0,5 e $2,0 \mathrm{~cm}$. Os mesmos foram coletados na Rodovia Castro-Tibagi, na localidade tipo desta unidade, e também 
em afloramentos da Cachoeira do Rio São Jorge, na cidade de Ponta Grossa (PR).

Nas demais amostras os resultados não foram produtivos, contudo novas coletas foram realizadas e estão sendo objeto de estudo. Os resultados preliminares destas novas análises estão sendo discutidos por Misuzaki et. al. (em preparação).

Como visto, a utilização do método isocrônico $\mathrm{Rb} / \mathrm{Sr}$ para a datação radiométrica de sedimentos, pode apresentar bons resultados, como o resultado inédito aqui obtido para a Formação lapó, desde que todas as premissas básicas estabelecidas pelo método sejam rigorosamente admitidas. 


\section{5 - Seções Geológicos}

\section{5 .1 - Introdução}

As seções geológicas foram obtidas a partir da análise dos poços e furos de sondägem relacionados na seção 2.2 (Fig. 25). As seções foram construídas com base na correlação dos padrões das curvas de raio gama e de potencial expontâneo, através da definição de marcos estratigráficos identificados nos perfis por superfícies contínuas, com um padrão de assinatura específico, de fácil observação nos poços utilizados. Estas superfícies representam eventos de inundação marinha, os quais são considerados, na magnitude da seção, como horizontes isócronos. As correlações foram elaborados utilizando-se, também, os dados bioestratigráficos discutidos na seção 2.3.

Foram elaboradas seções para todos os intervalos de tempo analisados nesta pesquisa. Ao todo foram preparadas oito seções estratigráficas envolvendo rochas do Ordoviciano, Siluriano, Eo-Devoniano e Meso-Devoniano, nas porções brasileira e paraguaia da Bacia do Paraná.

\subsection{2 - Seções envolvendo rochas do Ordoviciano / Siluriano}

As seções elaboradas para este intervalo de tempo foram levantadas através da correlação estabelecida entre afloramentos e poços, localizados na parte norte e sul da porção brasileira da bacia e pela correlação de furos de sondagem na porção paraguaia da Bacia do Paraná. 


\subsubsection{1 - Seção Chapada dos Guınarães (MT) - Poço 2-LA-1-SP}

Esta seção, com direção NW a SE, envolve a área de afloramento do pacote sedimentar Ordoviciano e Siluriano na região da Chapada dos Guimarães (MT) e os poços 2-AG-1-MT, 2-RA-1-MS, 2-TL-1-MT e 2-LA-1-SP (Fig. 33). Com exceção do poço 2-TL-1-MT, cujo a assinatura elétrica é dada pelo perfil SP, nos demais poços a correlação foi baseada no padrão dos perfis de Raio Gama. Como datum de correlação foi utilizada a superfície de inundação marinha Llandoverina datada no poço do 2-TL-1-MT.

Na seção o conjunto sedimentar ordoviciano, totalmente incluido na Formação Alto Garças, apresenta uma terminação abrupta em direção a noroeste e um afinamento em direção a sudoeste, estando ausente a partir do poço 2-RA-1MS. Embora não datados, os sedimentos da Formação Alto Garças são considerados de idade Ordoviciana, em função da relação de contato brusco entre estes sedimentos e os sedimentos sobrepostos associados à Formação Vila Maria, bem caracterizado no poço 2-AG-1-MT (Zalán et. al., 1987 e Pereira, 1998).

A distribuição destes sedimentos demonstra a existência de algum controle pós-deposicional na preservação do registro sedimentar. A terminação abrupta dos sedimentos ordovicianos em direção à Chapada do Guimarães e a deposição, nesta região, de sedimentos eo-devonianos diretamente sobre o embasamento evidenciam a atuação de um evento modificador pós-siluriano. Em direção à oeste a seção ordoviciana apresenta uma tendência de afinamento. No poço 2-RA-1-MS, conglomerados associados à Formação Vila Maria estão depositados diretamente sobre o embasamento, sendo os mesmos recobertos pela superfície de inundação eo-llandoveriana. Este mesmo arranjo se repete no poço 2-TL-1-MT. Neste último poço os sedimentos assentam-se 


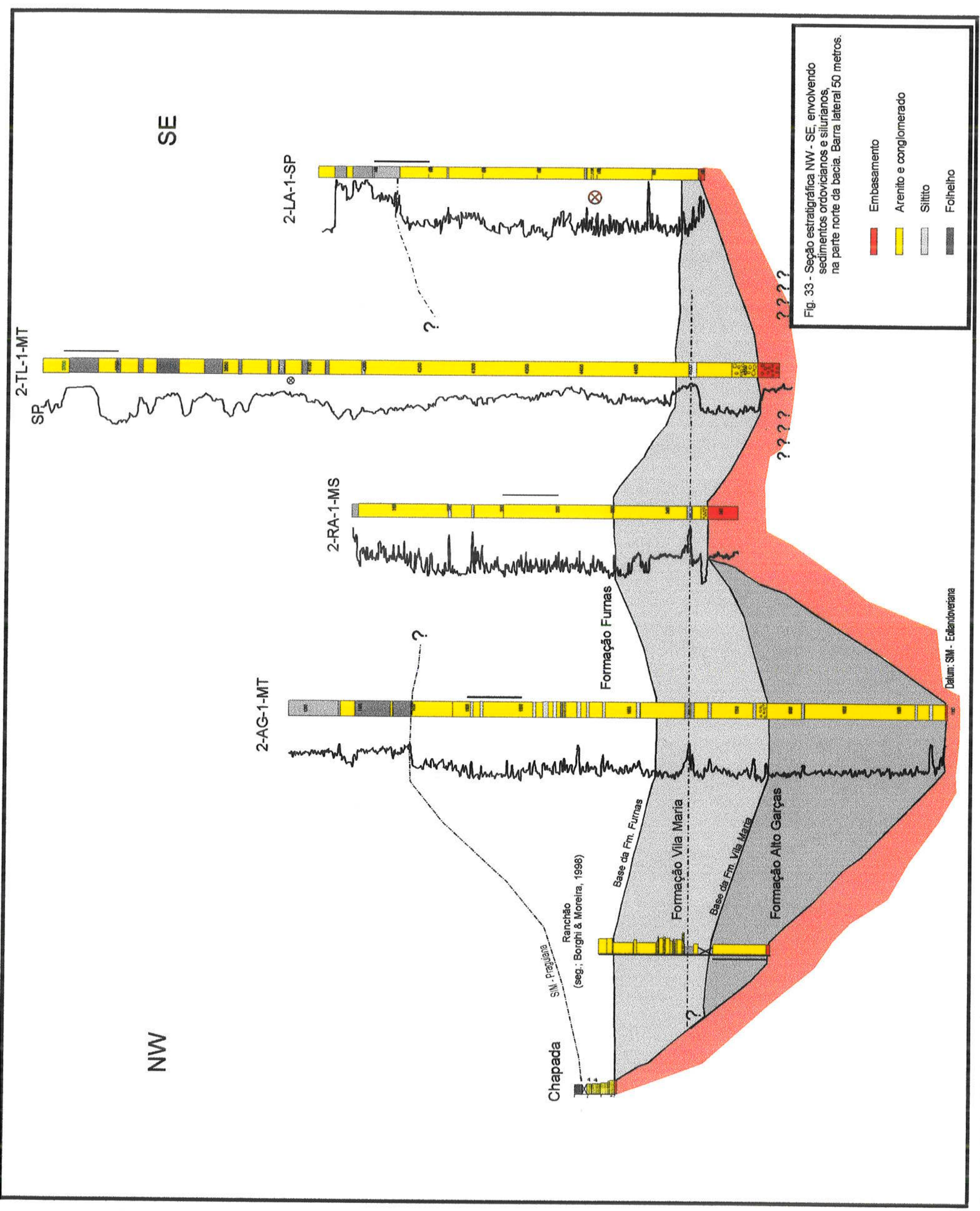


diretamente sobre rochas básicas, denominadas basalto Três Lagoas. Essas rochas foram datadas por Mizusaki (1989; apud Milani, 1997) como do NeoCarbonífero pelo método K-Ar. No entanto, segundo Milani (1997) em função da posição estratigráfica do basalto e seu estado de oxidação, a idade obtida não pode ser considërada. Nas seções estabelecidas por Milani (1997) admite-se que este basalto ocorra intercalado aos sedimentos ordovicianos, gerando desta forma um possivel espessamento deste conjunto sedimentar no poço. Convém ressaltar que o pacote sedimentar que está assentado sobre o basalto Três Lagoas possui em sua base conglomerados, os quais estão em contato com as rochas básicas. Estes sedimentos são aqui correlacionados à Formação Vila Maria. Esta correlação é proposta em função da idade Eo-Siluriana obtida nos sedimentos finos e, também, pelas características sedimentológicas observadas neste poço, que são distintas daquelas analisadas para o intervalo ordoviciano do poço 2-AG1-MT. Por outro lado, as rochas básicas apresentam um perfil de oxidação que pode ser interpretado como indicativo da ação de processos intempéricos (exposição). Assim, os sedimentos eo-silurianos descritos neste poço estariam assentados em discordância com as rochas básicas.

A partir destas evidências é difícil estabelecer uma cronologia de eventos para entender o possível afinamento da seção ordoviciana em direção à leste, uma vez que a mesma poderia ter sido originalmente depositada sobre as rochas básicas e posteriormente retirados por erosão ou ter sua deposição inicial controlada por uma calha de direção NE limitada na regiäo do poço 2-RA-1-MS.

Em termos sedimentológicos, a seção ordoviciana se apresenta essencialmente arenosa. As estruturas sedimentares observadas nos testemunhos 22 e 23 do poço 2-AG-1-MT (Fig. 27b) indicam que a deposição dos sedimentos ocorreu em um ambiente marinho raso (upper shoreface), de forma similar as condições de deposição descritas por Borghi \& Moreira (1998) na região 
da Chapada dos Guimarães. A provável presença do icnogênero Skolitnos (Milani, 1997), no testemunho 23, reforça esta hipótese.

O pacote sedimentar siluriano, litoestratigraficamente definido como Formação Vila Maria, apresenta uma regular distribuição ao longo da seção, com exceção da região da Chapada onde, de maneira similar ao pacote ordoviciano, ocorre uma perda abrupta dos sedimentos silurianos. Para leste, também se observa uma progressiva diminuição da espessura da seção siluriana, em direção ao poço 2-LA-1-SP. Neste poço, sobre o embasamento deposita-se um conjunto arenoso, com cerca de 20 metros de espessura, arranjado sob a forma de um ciclo de espessamento para o topo, que é associado ao conjunto regressivo da Formação Vila Maria. Tanto para este poço (2-LA-1-SP) como para o poço 2-RA1-MS, o limite entre os pacotes associados à Formação Vila Maria e à Formação Furnas foi estabelecido pela mudança no padrão do perfil de Dipmeter.

O padrão de empilhamento dos sedimentos silurianos observado nos poços reproduz o mesmo arcabouço transgressivo - regressivo anotado, em afloramento, para os sedimentos silurianos associados à Formação Vila Maria. $\mathrm{Na}$ seção, evidencia-se claramente o arranjo retrogradacional das parasseqüências até a superfície de inundação máxima, e a partir desta, o empilhamento progradacional das mesmas, bem marcado por ciclos de espessamento para o topo observados no poço 2-RA-1-MS. Em termos genéticos, a seção siluriana pode ser entendida como uma seqüência de segunda ordem, no sentido de Vail et al. (1977b). Na seção, não há elementos para se mapear o trato de mar baixo e trato transgressivo. No entanto, em afloramento é possivel diferenciar estes tratos, como no afloramento da Fazenda Bacuri (Fig. 21A), onde a superfície transgressiva marca 0 limite entre sedimentos arenosos com estrutura convoluta, associados ao do trato de mar baixo e sedimentos ricos no icnogênero Skolithos, entendidos como do trato transgressivo. 
O limitado número de testemunhos nesta seção (2-TL-1-MT; testemunho 38, Fig. 30C) dificulta a melhor caracterização dos ambientes de deposição em subsuperfície. Contudo, em função das datações obtidas no poço 2TL-1-MT, para o intervalo entre 4551 e 4500 metros, que possibilitaram uma melhor correlação com os dados de afloramentos, podemos, então, com base nesta correlaçãö e no padrão de empilhamento dos sedimentos nos poços, estender os ambientes observados em afloramento para o interior da bacia.

\subsubsection{2. - Seção 2-DO-1-MT - Cachoeira das Perdizes (GO)}

Esta seção envolve os poços 2-DO-1-MT, 2-CG-1-MT, 2-RA-1-MS e o conjunto sedimentar siluriano aflorante na região da Cachoeira das Perdizes (Fig. 34). A mesma apresenta uma direção SW - NE e teve, também, como datum de correlação a superfície de inundação marinha Llandoveriana. Desse modo, esta seção possui um caráter cronoestratigráfico para os sedimentos pré-Furnas. Um fator que limita a correlação é a assinatura elétrica utilizada nos perfis 2-DO-1MT e 2-CG-1-MT (perfis SP).

Na seção, a maioria dos sedimentos pré-Furnas estão associados à Formação Vila Maria com exceção do poço 2-DO-1-MT, onde estes sedimentos foram subdivididos nas formações Vila Maria e Alto Garças. Esta divisão foi realizada com base na mudança do padrão do perfil SP, que pode ser observada em torno da profundidade de 3960 metros. Uma idade Eo-Llandoveriana foi obtida para os sedimentos da Formação Vila Maria em afloramentos da Cachoeira das Perdizes. 


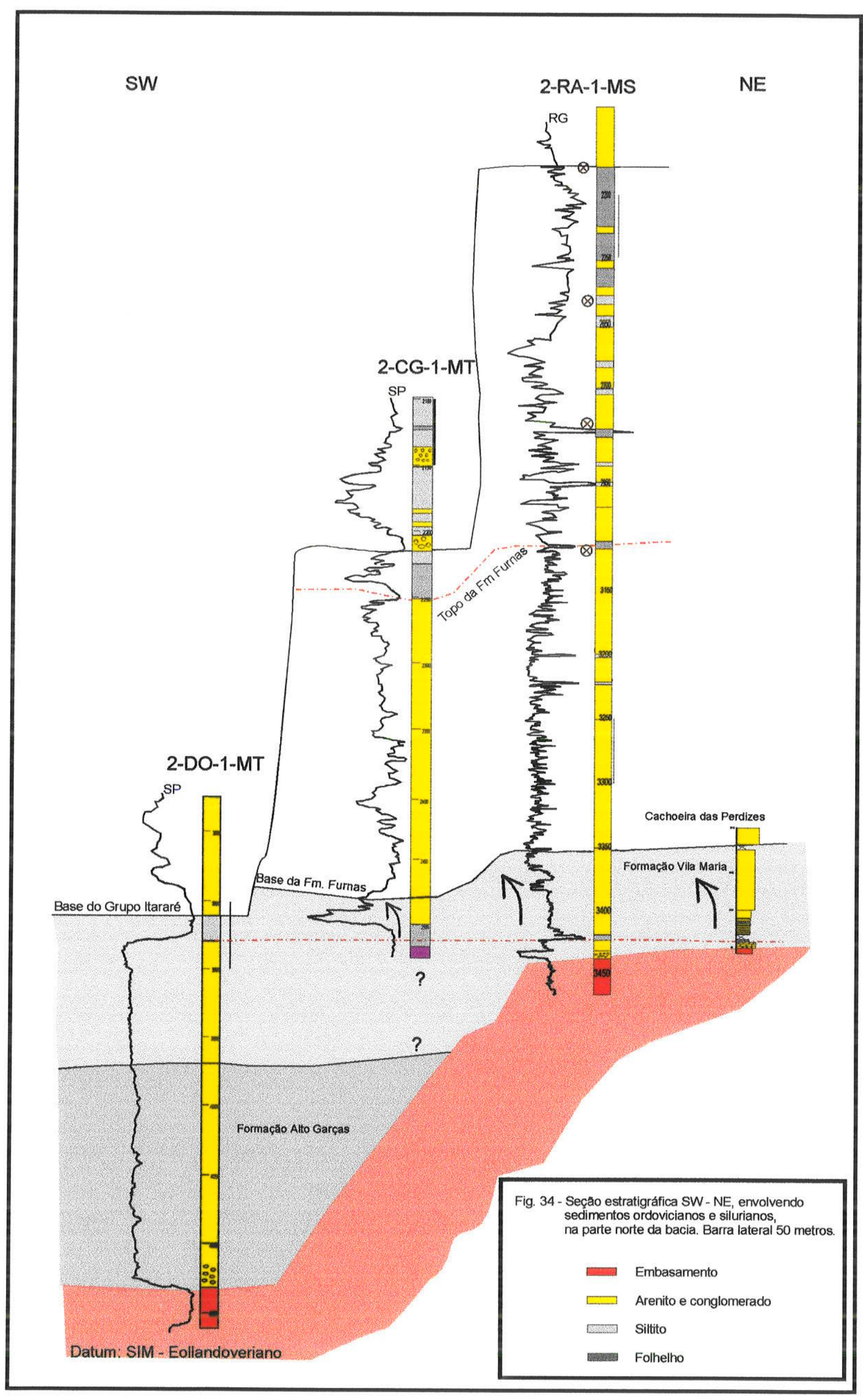


A distribuição dos sedimentos silurıanos nesta seção demonstra um espessamento deste conjunto em direção ao poço 2-DO-1-MT. Neste poço, um espesso pacote arenoso inicialmente atribuível à Formação Furnas está depositado sobre o embasamento. A assinatura elétrica do poço não possibilita uma maior acuidade nesta correlação. Contudo, a análise palinológica dos folhelhos sobrepostos a estes arenitos indicam uma assembléia fossilifera pobre, composta por raros elementos de idade, provavelmente, Llandoveriana e por elementos mais jovens como pólens, identificados como contaminação. Dessa forma, este pacote arenoso poderia ser correlacionada aos sedimentos préFurnas. No entanto, a análise da literatura demonstra a existência de interpretações alternativas. No perfil composto, datado de 1961, os sedimentos arenosos estão associados à Formação Furnas sendo limitados no topo por uma discordância com o Grupo Itararé, representado por folhelhos e arenitos. No arquivo geral e litológico de poços da Petrobrás, datado de 1995, o conjunto arenoso, também, é correlacionado à Formação Furnas, porém o fino pacote de folhelho sobreposto aos arenitos é associado à Formação Ponta Grossa. A mesma é limitada no topo pelo truncamento gerado pelas rochas do Grupo Itararé. Uma outra proposta foi apresentada por Assine et al. (1994). Esses autores associaram os arenitos, localizados abaixo dos folhelhos, ao Grupo Caacupé, os folhelhos à Formação Vila Maria e parte dos arenitos sobrepostos aos folhelhos à Formação Furnas.

A associação dos sedimentos arenosos observados na parte inferior do poço 2-DO-1-MT à Formação Furnas ou, de forma alternativa, ao conjunto préFurnas implica em duas história evolutivas antagônicas, onde na primeira situação teriamos um afinamento progressivo da seção ordoviciana / siluriana em direção à oeste, estabelecendo nesta posição o limite da bacia para este intervalo de tempo ou, conforme a segunda hipótese, teríamos na verdade um abrupto espessamento da seção pré-Furnas. O mesmo teria um caráter localizado, uma vez que em afloramentos descritos na região de Rio Negro, na atual borda oeste da bacia (Fig. 01-B), observa-se uma diminuição na espessura dos sedimentos posicionados 
abaixo da superficie de inundação. Nesta região a espessura máxima entre o embasamento e a superfície de inundação marinha é de 40 metros.

No poço 2-CG-1-MT a perfuração não atingiu o embasamento. A mesma parou em biabásios sotopostos a cerca de 15 de metros de siltitos. Estes últimos sedimentos mostraram-se infrutiferos em ternos palinológicos. Contudo, 0 empilhamento estratigráfico observado neste poço para os sedimentos pré-Furnas nos leva a associá-los à Formação Vila Maria. Deste modo, a seção demonstra um progressivo aumento de espessura em direção a região sudoeste da bacia. Por outro lado, em direção a leste e nordeste o espessamento do conjunto sedimentar, junto a atual borda da bacia, indica que a bacia, no tempo Siluriano, possuía uma maior amplitude do que aquela atualmente preservada.

O arranjo sedimentar observado para os sedimentos silurianos é bastante consistente podendo o mesmo ser facilmente seguido tanto em subsuperfície como em afloramento, sobretudo para o intervalo regressivo da seqüência siluriana. A ausência de testemunhos impossibilita uma meihor análise do conjunto sedimentar posicionado abaixo dos folhelhos eo-llandoverianos, em especial no poço 2-DO-1-MT. Neste mesmo poço, os sedimentos associados à Formação Alto Garças são, predominantemente, conglomeráticos e com estratificação cruzada planar. Tais características podem indicar um caráter mais continental para a deposição dos mesmos.

\subsubsection{3. - Seção Assunção 1 - RD-115}

O detalhamento bioestratigráfico realizado nos poços e furos de sondagem da parte paraguaia da bacia, em especial para o intervalo NeoOrdoviciano / Eo-Devoniano, possibilitou uma melhor definição do empilhamento estratigráfico sobretudo por permitir correlações mais criteriosas. A seção em destaque (Fig. 35) foi elaborada envolvendo o poço Assunção 1 e os furos de 
sondagem RD-116 e RD-11b. A mesma possui uma direção aproximadamentલ iv$S$ e teve como datum de correlação a superfície de inundação Llandoveriana.

Esta seção enfoca, preferencialmente, a distribuição dos sedimentos silurianos na parte paraguaia da bacia. Os furos RD-116 e RD-115, por se tratarem de sondagens rasas, apresentam um registro sedimentar incompleto, onde predominam os sedimentos silurianos. $O$ estudo detalhado dos aspectos bioestratigráficos e sedimentológicos destes furos, bem como a assinatura estratigráfica observada para o intervalo Llandoveriano tornou possivel, através das correlações estabelecidas, a identificação de sedimentos de idade EoLlandoveriana, associados à Formação Euzébio Ayala, no poço Assunção 1.

Este poço apresenta o registro mais completo da seção paleozóica da Bacia do Paraná no Paraguai. Para o intervalo de estudo foi redefinido o arranjo estratigráfico das unidades silurianas e eo-devonianas. No empilhamento observado, os sedimentos equivalentes à Formação Ponta Grossa estão limitados na base, em torno da profundidade de 2355, pela Formação Santa Elena. Esta se estende até 2660 metros onde são identificados níveis de conglomerado, que delimitam a parte inferior desta unidade. Os sedimentos equivalentes à Formação Ponta Grossa e aqueles associados à Formação Santa Elena não estão registrados nos furos de sondagem estudados. No poço Assunção 1 foram identificadas todas as unidades que compöem o Grupo Itacurubí. Este pacote sedimentar atinge uma espessura de cerca de 390 metros. A parte inferior deste grupo é constituída por sedimentos associados à Formação Euzébio Ayala. $O$ limite inferior desta unidade foi posicionado em 3050 metros, baseando-se na mudança do padrão de assinatura do perfil de raio gama e pela caracterização de um espesso conjunto arenoso anômalo. Em termos genéticos este limite pode corresponder a base de uma seqüência de maior ordem hierárquica. 
Assunçăo 1

N

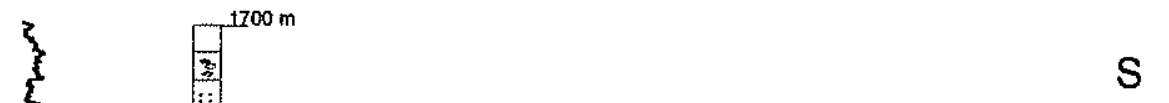

$=$ Pridoliano ao Lochkoviano

$B=$ Lochkoviano

$\mathrm{C}=$ Lochkoviano / Praguiano

2200

종

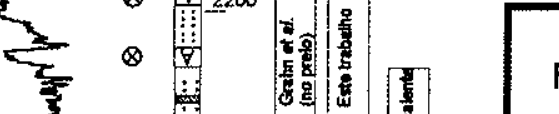

Fig. 35 - Seção estratigráfica N - S, envolvendo sedimentos ordovicianos e silurianos, na parte paraguaia da bacia.

[४ Vulcânica

arenito e conglomerado

$\square$ Siltito

Folhelho 
O Grupo Caacupé, neste poço, apresenta uma espessura mínima de 175 metros, uma vez que a sondagem foi finalizada em 3223 metros sem ter atingido o embasamento. No poço Assunção 1 não existem elementos para se individualizar as diferentes unidades do referido grupo. No entanto, no furo de sondagem 268-R2 (Fig. 36) podem ser identificados sedimentos associados ao conglomerado P'araguarí e a Formação Cerro Jhú. O conglomerado Paraguarí, com cerca de 40 metros de espessura, assenta-se diretamente sobre o embasamento. Este conjunto sedimentar é composto por conglomerados e arenitos conglomeráticos normalmente maciços. As características sedimentológicas observadas permite admitir que os depósitos de subsuperfície também foram depositados em um contexto de leque proximal como interpretado, para a mesma unidade em afloramento. Em sucessão aos conglomerados ocorrem, aproximadamente, 100 metros de arenitos de granulometria média a grossa, atribuídos à Formação Cerro Jhú, organizados em ciclos de afinamento para o topo e apresentando estratificação cruzada acanalada e tabular. O contexto deposicional que emerge deste arranjo faciológico é o de uma planície aluvial. 0 somatório do empilhamento deste conjunto sedimentar com o pacote correspondente a esta formação, observado em afloramento, permite reconstruir um modelo deposicional para o Grupo Caacupé, onde podem ser diagnosticadas desde as condições de leque proximal até a atuação de sistema do tipo "braid delta".

Nesta seção, as características sedimentológicas e o arranjo estratigráfico observados para o Grupo Itacurubi repete, em grande parte, as condições de deposição definidas para este grupo em superfície. No entanto, em subsuperfície, os sedimentos associados à Formação Euzébio Ayala apresentam um conjunto faciológico algo distinto ao diagnosticado em afloramento. No furos $\mathrm{RD}-116$ e RD-115, há um expressivo conjunto arenoso composto por arenitos médios a finos, intensamente fluidizados, que produz um aspecto maciço para as rochas. Nos pacotes maciços são observados, por vezes, estruturas de escape de fluido e convoluções. Ocorrem ainda, localizadamente, estratificação cruzada 
Furo de Sondagem 268-R2

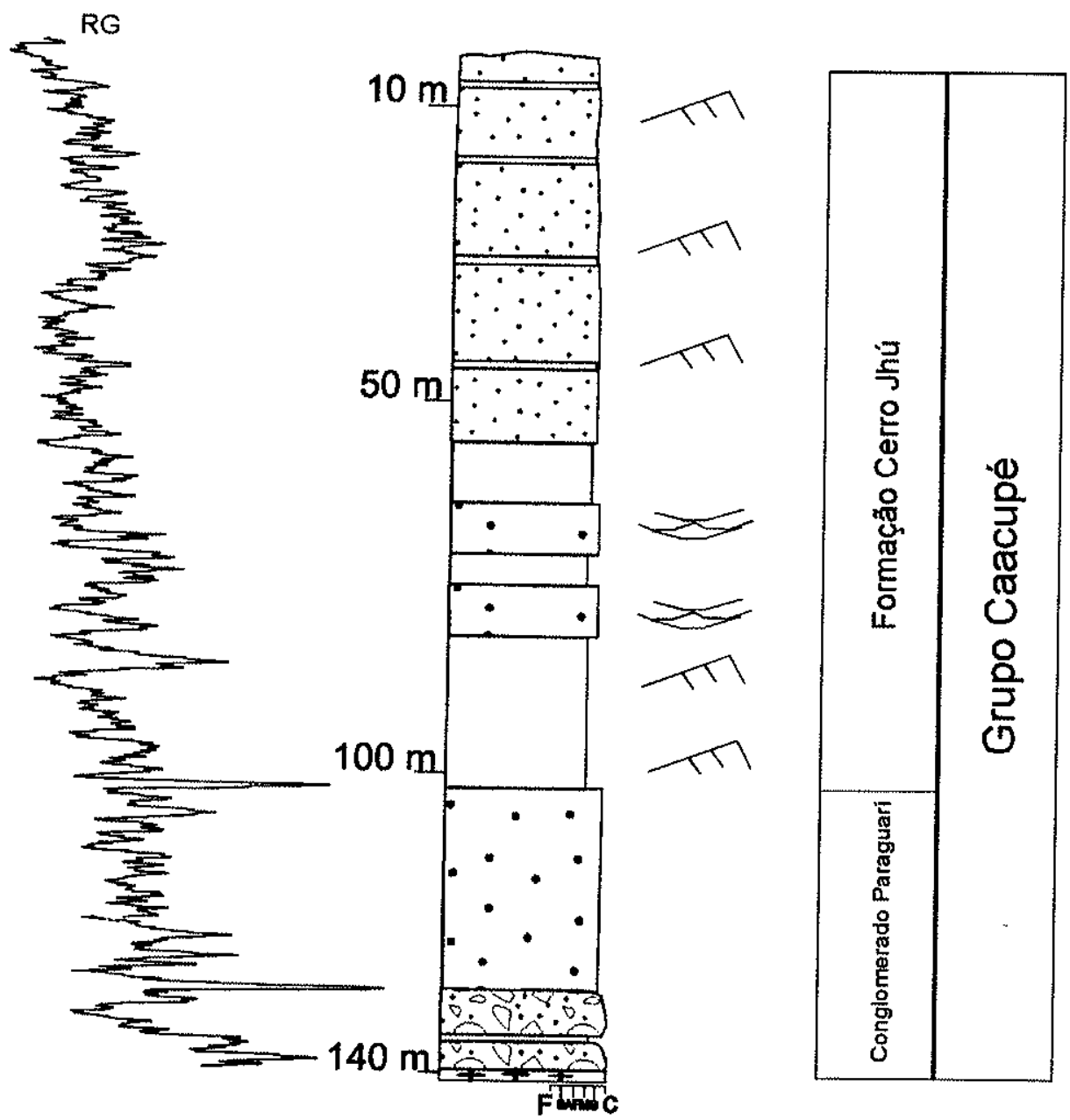

Fig.36 - Descriçăo litológica do furo de sondagem 268-R2.

Estr. cruz. acanalada

Estratificação cruz. tabular 
cavalgante. Esses pacotes organizam-se em ciclos de engrossamento para 0 topo, limitados por níveis de sedimentos finos. Esse arranjo, em ambos os furos, posiciona-se em direção à parte superior da unidade, abaixo da superfície transgressiva. Esse conjunto sedimentar é facilmente rastreado na seção, como também pode sër identificado nos sedimentos silurianos do poço 2-RI-1-PR (Fig. 37 e Fig. 31B), na parte brasileira da bacia. No furo RD-116 a superfície transgressiva é marcada pela presença de arenitos com oólitos ferruginosos e no poço 2-RI-1-PR, por um pacote arenoso com grânulos e seixos.

As características sedimentológicas do conjunto sedimentar em discussão, o seu arranjo estratigráfico, a geometria externa dos pacotes e a associação genética com depósitos de diamictito depositados por influência glacial, como no poço 2-RI-1-PR, permitem interpretar que os mesmos foram gerados por uma composição de fluxos trativos e gravitacionais, em uma posição periglacial, no contexto de uma progradação deltaica.

\subsubsection{4. - Seção 269 R1 - RD-115}

A seção em questão é composta pelos furos de sondagem 269-R1, 269-R3, RD-116 e RD-115 (Fig. 38). A mesma possui uma direção NW - SE e foi estabelecida utilizando-se como datum de correlação a superfície de inundação marinha eo-siluriana. A seção envolve sedimentos atribuídos ao Grupo Itacurubi.

A correlação entre os furos demonstra uma persistência lateral do padrão de empilhamento dos sedimentos, em especial daqueles associados à Formação Vargas Peña. Nos furos RD-116, 269-R3 e 269-R1 a espessura dos folhelhos e siltitos associados a esta unidade são constantes em torno de 70 metros. As idades obtidas para estes sedimentos no furo RD-116 são similares às idades divulgadas por Gray et al. (1992), a partir de amostras coletadas no furo 
269-R3, entre as profundidades de 35 e 80 metros. Segundo os autores, as espécies observados neste furo, tais como: Cyathochitina ssp, Dactylofusa maranhensis, Leptrolypa aniae e Oppilatala eoplanktonica, definem uma idade Meso a Neo-Llandoveriana (Aeroniano a Telychiano).

Nos sedimentos da Formação Vargas Peña predominam estruturas sedimentares do tipo: "wavy / linsen", estratificação cruzada por onda e intensa bioturbação. Essas características, corroboradas pelo conteúdo paleontológico, definem condições francamente marinhas de deposição (offshore).

\subsection{3 - Seção envolvendo rochas do Eo-Devoniano}

Em função dos diferentes padrões de registro dos sedimentos nos perfis compostos obtidos nesta pesquisa, envolvendo perfis de raio gama e de potencial expontâneo (SP), e da distância existente entre os poços optamos por estabelecer para este intervalo uma única seção utilizando-se somente os poços com perfil de raio gama.

\subsubsection{1 - Seção 2-RI-1-PR - 2-LA-1-SP}

Esta seção foi estabelecida ao longo da calha central da Bacia do Paraná envolvendo poços alinhados paralelamente ao Rio Paraná. A seção possui uma direção $S W$ - NE, sendo composta pelos poços 2-RI-1-PR, 3-CB-3-SP, 2-LA1-SP e 2-AR-1-SP (Fig. 39). A mesma compreende sedimentos de idade, provavelmente, Eo-Devoniana, associados à Formação Furnas. Como datum de correlação foi utilizada a primeira superfície de inundação observada no pacote sedimentar, bem definida na primeira parte dos sedimentos da Formação Furnas. 


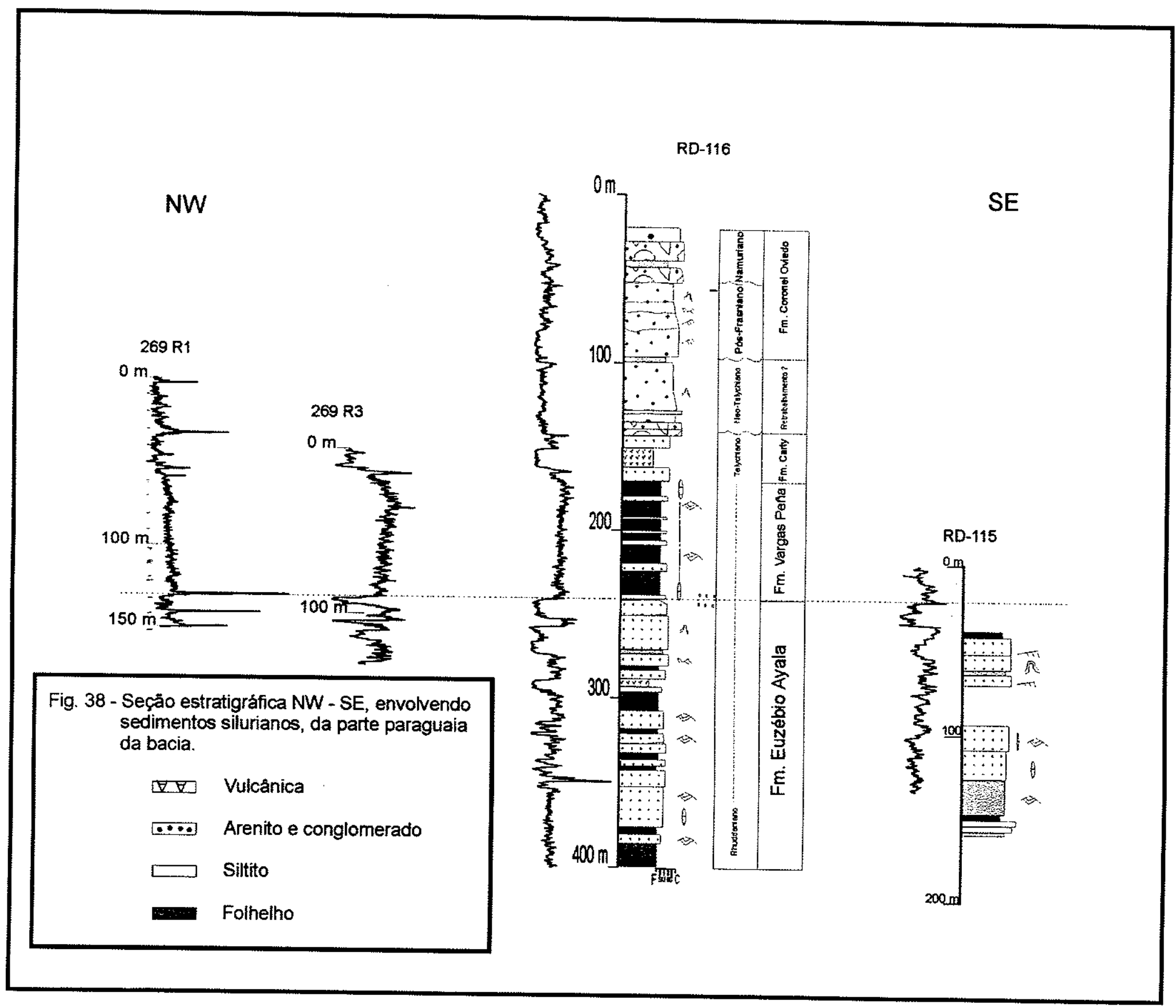


O pacote eo-devoniano da Bacia do Paraná, principalmente no domínio sul da bacia, tem sido alvo recente de estudos destinados a estabelecer um modelo estratigráfico, em especial para os sedimentos da Formação Furnas. Existe um razoável consenso em relação à caracterização do empilhamento do conjunto sedimentar em questão. Nos poços analisados nesta seção, e em outros descritos na literatura, pode ser identificado um padrão de empilhamento marcado por um ciclo inicial de afinamento normal até a porção intermediária da Formação Furnas, e a partir deste ponto ocorre um ciclo de engrossamento para o topo, evidenciado por uma deflexão da curva de raio gama para a esquerda. Este último ciclo é finalizado por uma nova migração da curva de raio gama para a direita, marcando o predomínio de folhelhos e siltitos associados à Formação Ponta Grossa. Os vários autores que estudaram este conjunto sedimentar (Assine, 1996; Milani, 1997; Bergamaschi, 1999) associam à variação relativa do nível do mar o controle do padrão de empilhamento dos sedimentos expresso na curva de raio gama.

$\mathrm{Na}$ literatura atual existem dois modelos genéticos propostos para a evolução sedimentar deste intervalo. Assine (1996) e Milani (1997) dividem o intervalo em discussão em dois ciclos. O primeiro ciclo envolveria os sedimentos basais da Formação Furnas e se estenderia até a superficie de inundação marinha na posição intermediária dessa unidade. O segundo ciclo teria início no terço superior da unidade e estaria limitado por uma discordância definida na base de uma sucessão de arenitos, associada a uma queda relativa do nível do mar. Estes arenitos apresentam um padrão em caixote nos perfis de raio gama e estão posicionados a cerca de 50 metros abaixo do contato Furnas - Ponta Grossa. Os mesmos são delimitados superiormente pelas "camadas de transição" (Petri, 1948), representadas por uma deflexão a direita da curva de raio gama.

De forma alternativa a este modelo, Bergamaschi (1999) acredita que esta deflexão para direita verificada no topo da Formação Furnas é uma resposta a um aumento de fácies pelíticas inseridas no próprio contexto dos sistemas 


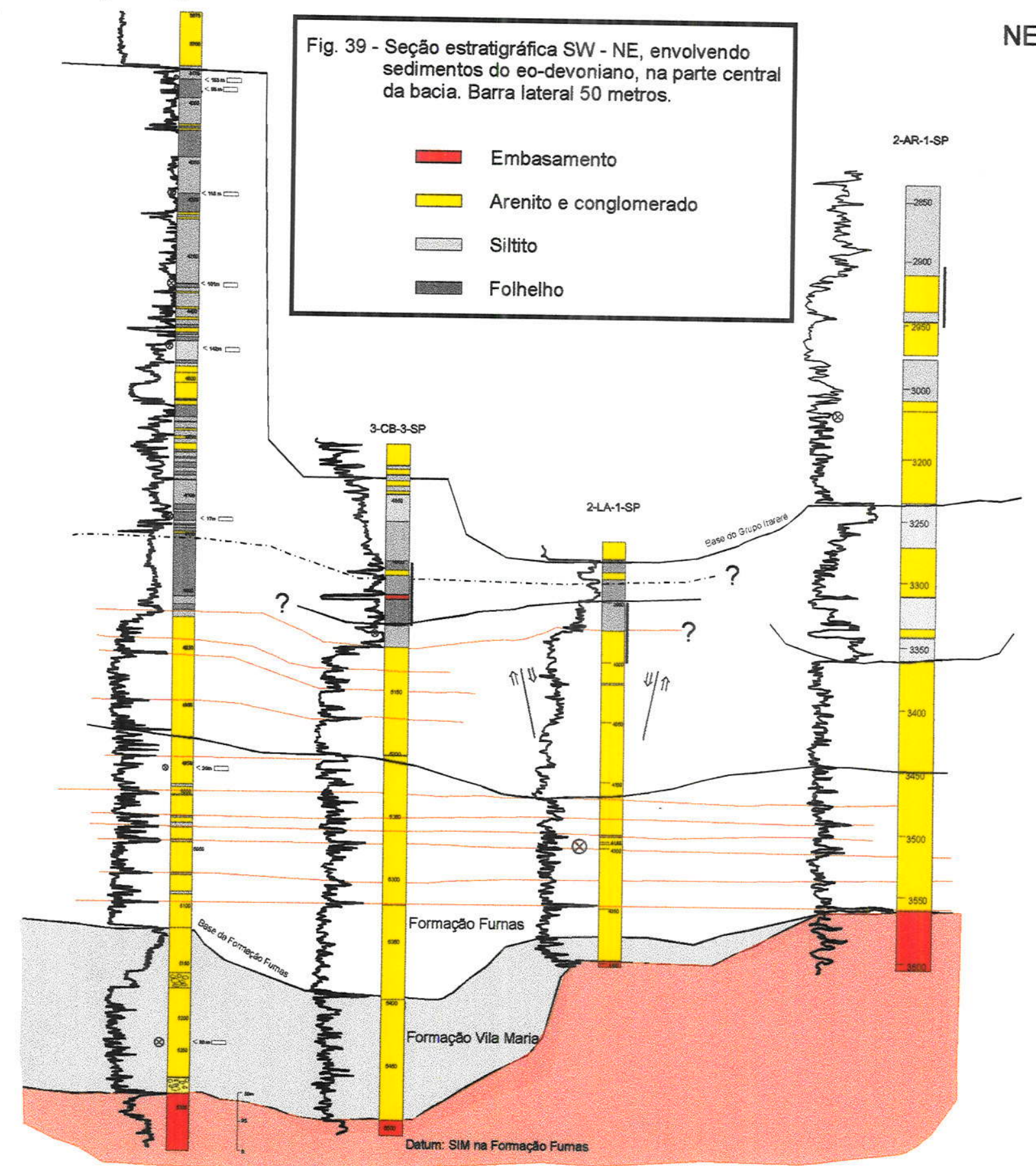


deposicionais atuantes na parte superior desta unidade. Para esse autor, os sedimentos da Formação Furnas estariam totalmente contidos em uma seqüência de $3^{\circ}$ ordem. Esta seqüência seria composta por um trato de sistema transgressivo na base, marcado pelo estaqueamento de pacotes arenosos com um padrão de räio gama em forma de caixote, que se estenderiam até a superfície de inundação máxima, posicionada no domínio central da unidade, coincidente com a inflexão relativamente mais acentuada à direita. A partir dessa superfície, sucede-se a tendência de suave inflexão à esquerda, culminando com padrões de assinaturas em caixote, progressivamente mais espessos, até o topo da seqüência. Este intervalo constitui o trato de sistema de mar alto. O limite superior desta seqüência é marcado pelo truncamento dos depósitos transicionais e costeiros do topo da Formação Furnas por arenitos finos com hummocky da base da Formação Ponta Grossa.

A definição de modelos genéticos evolutivos fundamentados nos conceitos da estratigrafia de seqüência, deve ter sua aplicação analisada com cautela. $O$ arcabouço bioestratigráfico para o conjunto eo-devoniano é ainda muito frágil, de forma que a definição de limites de seqüência de $2^{\circ}$ ou $3^{\circ}$ ordem ocorrerá, quase exclusivamente, por uma análise do padrão de empilhamento dos sedimentos, pois em termos bioestratigráficos não há resolução para se definir a magnitude dos hiatos. Na seção, esta situação é evidenciada pela análise dos poços 2-RI-1-PR, 3-CB-3-SP e 2-LA-1-SP. Os resultados bioestratigráficos apresentados no poço 2-RI-1-PR indicam uma idade Lochkoviana para a base dos sedimentos da Formação Ponta Grossa. Em recente trabalho, Gerrienne et al. (submetido, 1999) definem uma idade Eo-Lochkoviana para o topo da Formação Furnas, a partir da análise do registro palinológico e paleobotânico da região de Jaquariaiva (PR). Com base nestas idades, não existiria um hiato significativo entre estas unidades. Em verdade, poderia ocorrer uma continuidade deposicional como observado no poço Assunção 1 (Fig. 35), onde os sedimentos equivalentes à Formação Ponta Grossa teriam uma idade similar àquela obtida para o topo da 
Formação Furnas em atloramento. No poço 2-RI-1-PR o pacote eo-devonıano pode ser dividido, ao menos, em 06 parasseqüências bem definidas por superfícies de inundação.

O empilhamento sedimentar observado no poço 3-CB-3-SP é comparável ao p̈oço 2-RI-1-PR, embora exista uma controvérsia com respeito à idade dos sedimentos da base da Formação Ponta Grossa. No perfil composto do poço 3-CB-3-SP é apresentada uma idade Emsiana a Givetiana para a base da unidade. $A$ análise de lâminas obtidas neste intervalo confirmam a presença de elementos jovens, contudo não se pode abandonar a hipótese de contaminação dos sedimentos, uma vez que há indícios de desabamento neste intervalo. Por outro lado, o arranjo sedimentar observado no poço 2-LA-1-SP, em especial para a sua metade superior, é algo distinto daquele registrado nos outros dois poços. A partir da profundidade de 4065 metros há uma mudança significativa no padrão da curva de raio gama. Esta mudança de padrão é também observada no registro do perfil dipmeter. Dessa forma, a mudança de padrão pode estar associada a um falhamento. Como no poço 3-CB-3-SP, o perfil do poço 2-LA-1-SP indica uma idade Givetiana para a base da Formação Ponta Grossa. Neste último poço, a análise do conteúdo palinológico das amostras coletadas em torno de 3950 metros confirma a presença de elementos associados a uma idade Devoniana mais jovem. As lâminas analisadas são provenientes de amostras de calha, fato que pode possibilitar a existência de contaminação. Contudo, nesta profundidade ocorre um brusca mudança no padrão dos perfis de raio gama e dipmeter. A variação no padrão dos perfis, em conjunto com a definição de uma idade devoniana mais jovem para os folhelhos acima da profundidade de 3950 metros, é indicativa de um limite de seqüência. Este limite pode ser correlacionado à quebra de seqüencia descrita em afloramentos na região de Rio Verde de Mato Grosso (MS).

A partir dos dados apresentados nesta seção, emerge um modelo genético de uma seqüência de $2^{\circ}$ ordem envolvendo todo o conjunto sedimentar 
associado à Formação Furnas mais os sedimentos das "camadas de transição", que na concepção de Bergamaschi (1999) incluem os depósitos tempestíticos da base da Formação Ponta Grossa. Em função do padrão de empilhamento dos sedimentos, a seqüência pode ser dividida em duas outras seqüências de $3^{\circ}$ ordem nos moldes proposto por Milani (1997). A primeira seqüência seria marcada na base pelo estaqueamento de pacotes arenosos com um padrão de raio gama em forma de caixote, que afinam progressivamente e diminuem de espessura em direção à superfície de inundação máxima, posicionada no domínio central da unidade. A segunda seqüência estaria posicionada no terço superior da unidade, sendo sua base marcada por uma sucessão de corpos arenosos espessos, que apresentam um afinamento para o topo. Os mesmos são limitados pela superfície transgressiva posicionada na base da Formação Ponta Grossa e representada pelo truncamento dos depósitos arenosos da Formação Furnas por depósitos tempestíticos da base da Formação Ponta Grossa. O limite inferior da segunda sequência está bem caracterizado no poço 3-CB-3-SP na profundidade de 5200 metros. A correlação deste limite nos demais poços sugere uma incisão de pequena magnitude gerada, provavelmente, por uma queda relativa do nível do mar. O padrão de empilhamento do conjunto sedimentar na base desta seqüência indica uma provável retomada da sedimentação fluvial na bacia, conforme sugerem as características sedimentares descritas no testemunho 4 do poço 2 AR-1-SP (Fig. 40). O conjunto sedimentar deste poço é aqui admitido como pertencente à Formação Furnas em função dos resultados bioestratigráficos alcançados no mesmo, do padrão do empilhamento sedimentar e das características faciológicas dos sedimentos.

\subsection{4 - Seção envolvendo rochas do Meso e Neo-Devoniano}

Os sedimentos do Meso / Neo-Devoniano foram discutidos em duas seções de correlação; uma na parte norte da Bacia do Paraná no Brasil e uma segunda localizada na porção paraguaia da bacia. 


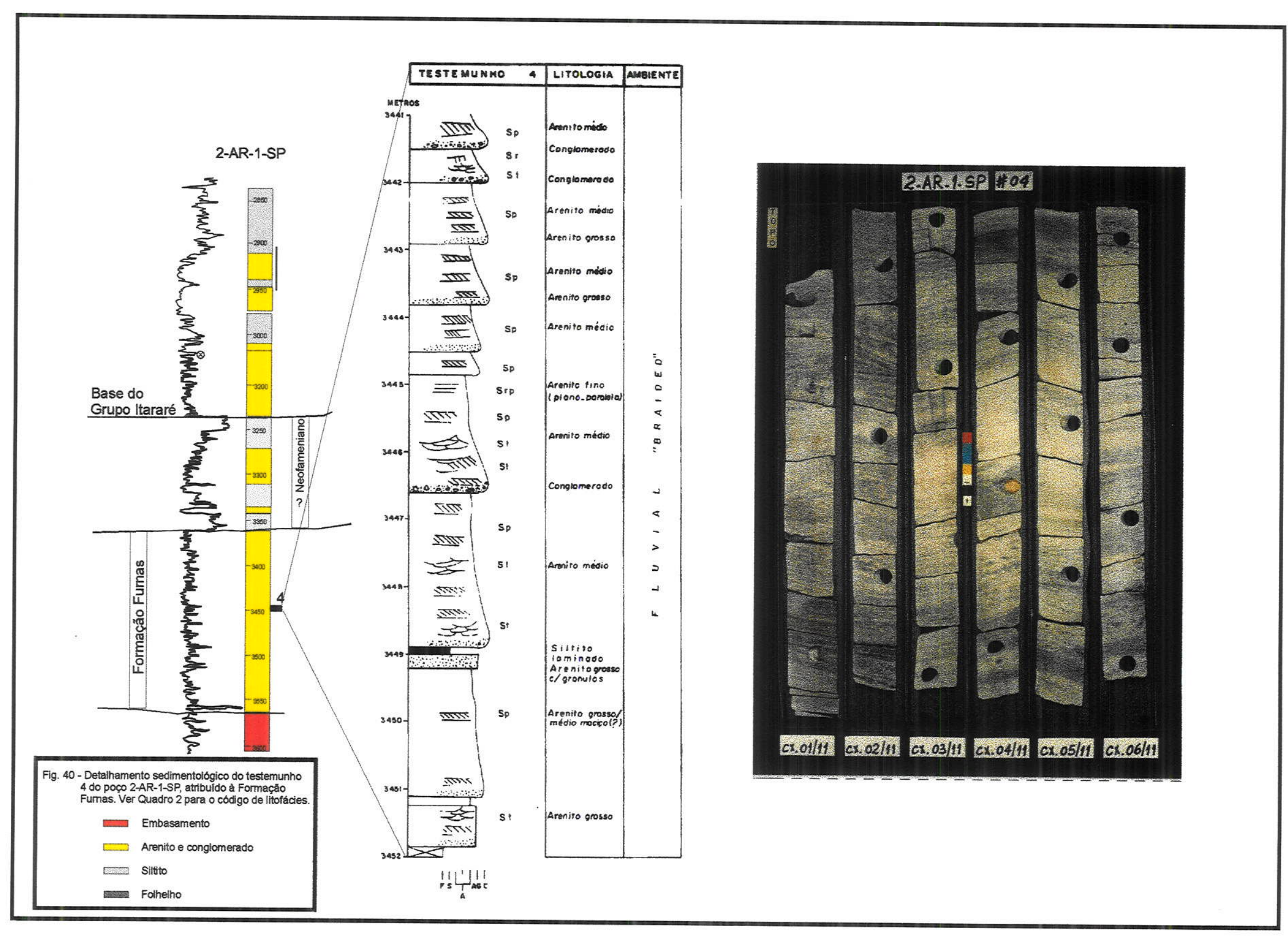




\subsubsection{1 - Seção 2-AG-1-MT - 2-TL-1-MT}

Esta seção, enfocando os sedimentos devonianos, foi preparada utilizando-se os poços 2-AG-1-MT, 2-JA-1-Go e 2-TL-1-MT (Fig. 41). A mesma possui uma direção NNW a SSE e teve como datum de correlação uma superfície de inundação marinha posicionada por Grahn (1998), no poço 2-AG-1-MT, no limite Efeliano / Givetiano.

A sedimentação eo-devoniana registrada nesta seção apresenta uma sucessão sedimentar comparável àquela descrita na calha central da bacia. No poço 2-AG-1-MT, próximo à profundidade de 1550 metros, ocorre um deflexão da curva de SP para à direita. Embora o perfil de SP não reflita com a mesma precisão de uma curva de raio gama a variação da argilosidade, podemos inferior um ciclo de afinamento normal, a partir da base da unidade até esta posição. Após este intervalo mais argiloso, sucede-se um padrão de engrossamento para o topo, limitado superiormente pelos sedimentos finos da Formação Ponta Grossa. Esta ciclicidade está também refletida nas características sedimentológicas observadas nos testemunhos. O testemunho 20 (Fig. 27b) deste poço indica que a deposição neste intervalo ocorreu em condições de plataforma rasa a costeira. Utilizando-se os dados sedimentológicos do testemunho 36 do poço 2-JA-1-GO (Fig. 28b), indicativos de uma deposição em condições mais continentais, observa-se uma progressiva implantação de ambientes mais distais na bacia, em direção à porção intermediária da unidade. A partir da observação do testemunho 37 do poço 2-TL1-MT, este progressivo afogamento, aparentemente, ocorre de NNW para SSE, uma vez que as características deposicionais observadas neste testemunho indicam condições mais proximais de deposição em relação ao testemunho 20 do poço 2-AG-1-MT, situado em uma posição estratigráfica similar. A retomada de condições mais continentais de deposição na bacia, no segundo ciclo deposicional, fica evidenciada pelas características faciológicas apresentadas nos testemunhos 34 do poço 2-JA-1-GO e 19 do poço 2-AG-1-MT. 


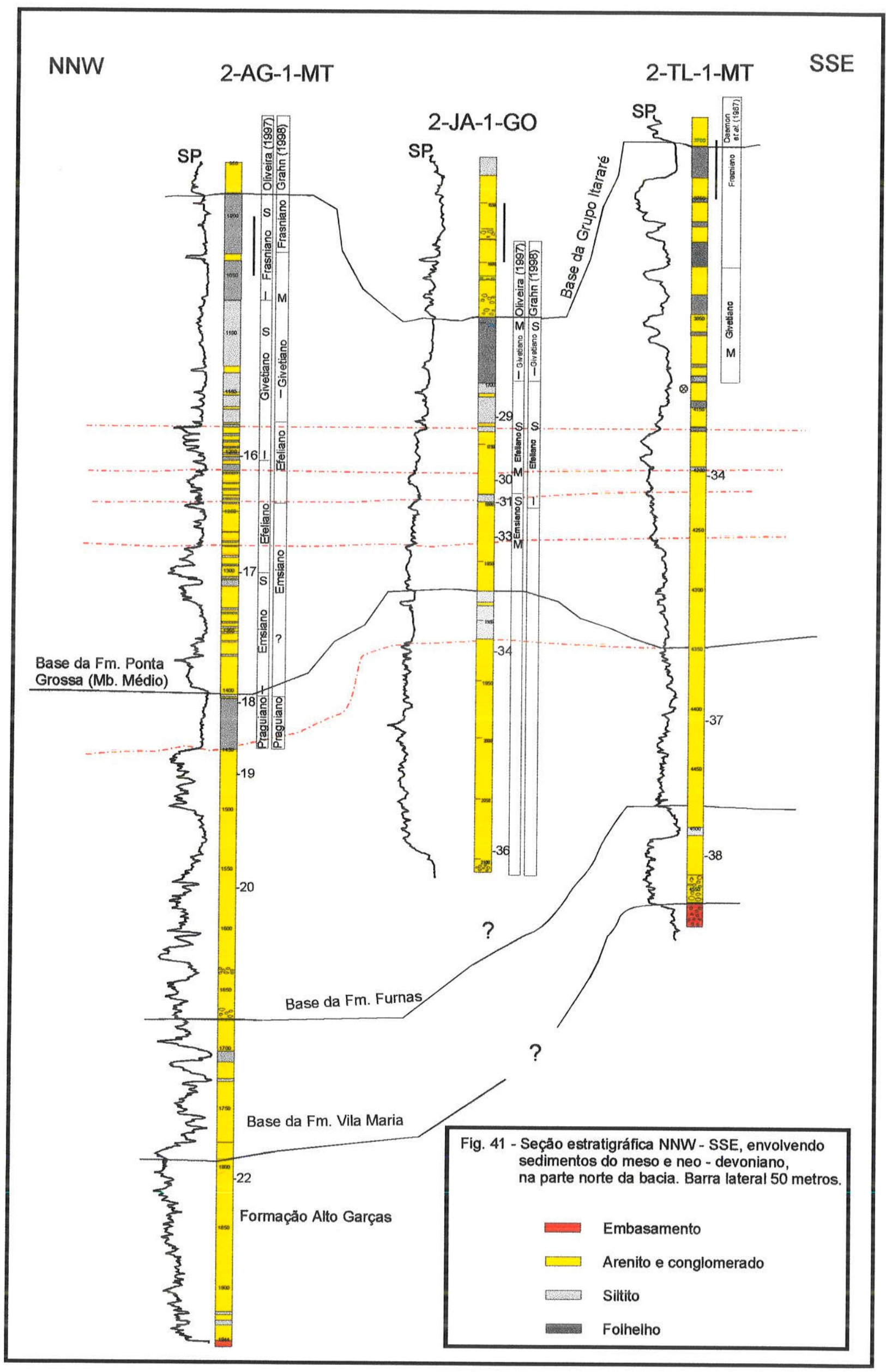


Nestes testemunhos a deposição ocorre em situações costeiras, em especial no testemunho 34 , onde a sedimentação ocorreu sob a ação de um sistema deposicional do tipo "braid delta".

A "distribuição dos sedimentos do Meso-Devoniano na seção demonstra um expressivo espessamento dos mesmos no poço 2-AG-1-MT, onde depositam-se abruptamente sobre sedimentos do eo-devoniano. No poço 2-TL-1MT os sedimentos eo-devonianos estão ausentes e os sedimentos do mesodevoniano assentam-se diretamente sobre a Formação Furnas. Em termos litoestratigráficos optamos por manter a proposição original de Andrade \& Camarço (1980) que denominaram estes sedimentos, em afloramento, como Membro Médio da Formação Ponta Grossa.

O truncamento dos sedimentos eo-devonianos por sedimentos do Membro Médio da Formação Ponta Grossa bem caracterizado nesta seção é, também, descrito em outras posiçōes da bacia. Na faixa de afloramento posicionada na borda oeste da bacia este truncamento pode ser observado na cidade de Rio Verde de Mato Grosso (MT), no barreiro Felix (Fig. 4b-A). Neste afloramento, tempestitos associados ao membro médio estão em contato erosivo com sedimentos praguianos. Esta situação se repete na margem nordeste bacia, na região entre Amorinópolis (GO) e Ivolândia (GO), onde estes sedimentos assentam-se sobre o embasamento. Aparentemente, na região da Bacia do Parecis esta situação se repete.

Essa relação erosiva entre os sedimentos do meso e do eodevoniano é também evidenciada no poço 2-AG-1-MT, pela brusca mudança faciológica observada entre os testemunhos 18 e 17 . No testemunho 18 os aspectos faciológicos indicam condições marinha franca de deposição (offshore) que são abruptamente substituidas por condições deposicionais de plataforma 
rasa, como pode ser caracterizaau nos sedimentos observados no testemunho 17 , localizados em uma espessa cunha arenosa.

A definição do hiato temporal envolvido neste truncamento é de difícil determinação, uma vez que os pacotes arenosos não foram datados. Contudo, uma estimativa, énvolvendo ao menos a perda de todo o intervalo Emsiano, pode ser inferida a partir das informações coletadas na região de Rio Verde de Mato Grosso, como já discutido (p. 25). Se correlacionarmos a superfície efeliana, datada no afloramento, a superfície utilizada como datum desta seção, observaremos uma significativa mudança na taxa de deposição, em função da espessura reduzida do pacote arenoso, sotaposto à superfície de inundação, que trunca os sedimentos praguianos. Na borda nordeste, a magnitude de tempo envolvida neste hiato pode ser consideravelmente maior, em função da deposição dos sedimentos do membro médio diretamente sobre o embasamento, embora esta região seja caracterizada por altos locais.

O arcabouço estratigráfico discutido na seção permite agrupar os sedimentos do meso-devoniano e do neo-devoniano em uma seqüência de segunda ordem, tendo como limite inferior uma discordância associada à base dos arenitos do membro médio da Formação Ponta Grossa e limitada no topo pelo truncamento da seção devoniana pelos sedimentos do Grupo Itararé.

O preenchimento da seqüência é feito pelo empilhamento de ciclos de engrossamento granulométrico e estratal para o topo, com dezenas de metros de espessura, limitados por superfícies de inundação marinha, definidos como parasseqüências. A associação de fácies descritas nos testemunhos refletem claramente a tendência de arrazeamento para o topo, em função do preenchimento do espaço de acomodação. No poço 2-JA-1-GO, os testemunhos 30 e 31 demonstram esta tendência. No testemunho 31 a sucessão de fácies registra condições mais distais de deposição (shoreface inferior) que gradam para condições de plataforma rasa (shoreface superior) definidas pelas fácies do 
testemunho 30. O arranjo dos sedimentos em ciclos de arrazeamento para o topo (shallowing-upward), definido pelo empilhamento dos sedimentos em ciclos de coarsening up, foi detalhado por Pereira (1992) em afloramentos do membro médio no sudoeste de Goiás e interpretado como ciclos de agradação pontuada (PAC's) de Goodwin \& Anderson (1985).

A tendência de um predomínio de fácies mais proximais em direção a SSE, observada para os sedimentos eo-devonianos, parece se manter no tempo Meso-Devoniano. Comparando-se as características faciológicas dos testemunhos 34 do poço 2-TL-1MT, 30 do poço 2-JA-1-GO e 16 do poço 2-AG-1-MT, nota-se, a partir do testemunho 34 , uma contínua deposição dos sedimentos em posições cada vez mais distante da área fonte.

O conjunto de parasseqüências individualizados neste intervalo da seção comporia o trato de sistema transgressivo da seqüência de $2^{\circ}$ ordem. Dessa forma, a superfície transgressiva é posicionada junto a discordância. Este modelo reflete a distribuição dos tratos de sistema de uma seqüência estabelecida em um contexto de uma bacia em rampa, onde a queda relativa do nivel do mar não gera espaço deposicional suficiente para a preservação de grandes acumulações de sedimentos associados ao trato de sistema de mar baixo (Posamentier \& Allen, no prelo). Assim, com o incremento da taxa de subida relativa do nível do mar, os sedimentos do trato de mar baixo podem ser completamente retrabalhados pela ação das ondas. No entanto, como demonstram Walker \& Plint (1992), a superfície de ravinamento gerada no processo transgressivo pode preservar arenitos de "shoreface", associados ao trato de mar baixo, gerados em um processo de regressão forçada. Esses arenitos de "shoreface" de base abrupta estão envelopados por sedimentos lamosos de costa-afora (offshore). Ainda segundo este modelo, a superfície de ravinamento pode ser coberta por um pavimento transgressivo. O resultado final deste processo seria o empilhamento de uma sucessão de fácies iniciada por folhelhos e siltitos bioturbados, depositados em condições de plataforma externa, truncados 
por arerutos finos com estratificação cruzada por onda, associados a depósitos de "shoreface", limitados no topo por um pavimento de conglomerado gerado pela superficie de ravinamento e fechando o empilhamento depositam-se, novamente, lamitos marinhos de costa afora, em um contexto transgressivo.

As características acima descritas foram observadas em corpos arenosos, associados à base da seqüência, na região de General Carneiro (MT) (Fig. 15) e, parcialmente, em Rio Verde de Mato Grosso (MS) (Fig. 4a-C). Esses pacotes arenosos podem representar resquicios do trato de sistema de mar baixo, relativo à seqüência meso-neodevoniana. Em subsuperfície, o melhor conjunto sedimentar que poderia ser associado a este trato de sistema seria um pacote arenoso, com cerca de 30 metros de espessura, que marca a base da seqüência no poço 2-AG-1-MT, e deposita-se em contato abrupto com os sedimentos praguianos do topo da seqüência inferior.

Em sucessão ao trato transgressivo, sobrepõem-se depósitos distais de plataforma interna gerados pelo progressivo afogamento da bacia, que tem seu máximo de inundação no Frasniano, conforme os dados geoquímicos apresentados à frente. Aparentemente, ao longo de todo este intervalo, o aporte arenoso continua ocorrendo a partir da direção SSE.

\subsubsection{2 - Seção Assunção 1 - Assunção 2}

Esta seção foi estabelecida utilizando-se os dois principais poços perfurados na parte paraguaia da Bacia do Paraná, localizados no baixo de São Pedro (Fúlfaro, 1996) (Fig. 26). A seção teve por objetivo melhor entender a distribuição dos sedimentos do Meso-Devoniano, sobretudo após as novas datações obtidas para o poço Assunção 2 (Fig. 42). 


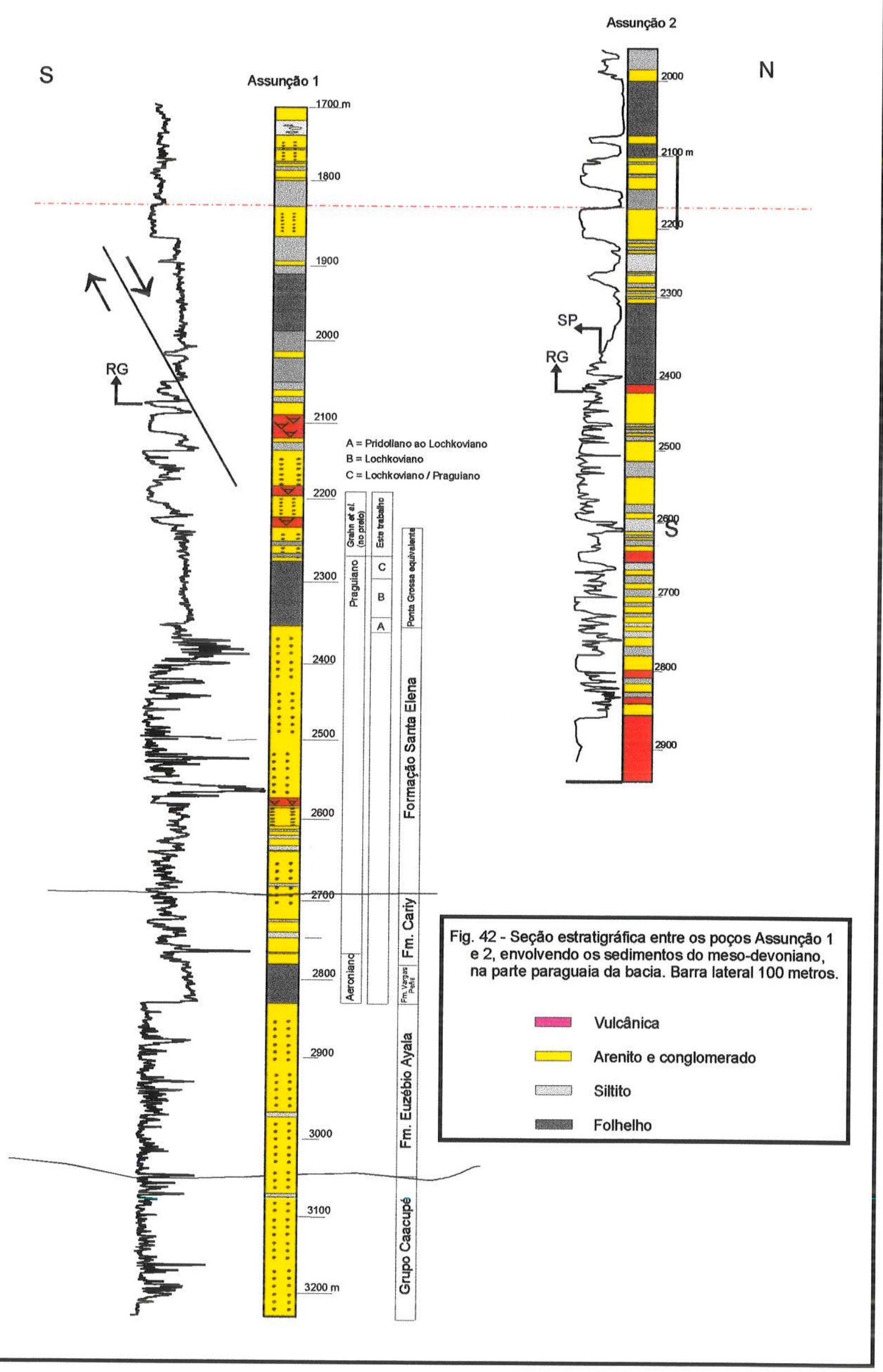


Os resultados palinológicos levantados no poço Assunção 2 indicam que 0 pacote sedimentar observado entre as profundidades de 2300 e 2400 metros possui uma idade Meso-Devoniana. Dessa forma, esses sedimentos são passíveis de correlação com aqueles registrados no poço Assunção 1, entre as profundidades de 1900 e 2060 metros. Para se montar a seção foi utilizado como datum de correläção a superfície de inundação localizada na profundidade de 1830 metros no poço Assunção 1.

Os sedimentos meso-devonianos do poço Assunção 1 apresentam um arranjo sedimentar muito similar ao descrito anteriormente para o poço 2-AG1-MT. Os sedimentos estão organizados em ciclos de engrossamento para o topo, com dezenas de metros de espessura. No poço, não está claro o truncamento entre os sedimentos do meso-devoniano e aqueles do eo-devoniano, como observado na seção anterior. Contudo, na profundidade de 2200 metros do poço Assunção 1 ocorrem níveis de conglomerado depositados sobre um pacote arenoso de granulometria fina, com geometria lenticular, que está depositado sobre os folhelhos bioturbados, associados ao Eo-Devoniano, depositados em condições de costa-afora. Seguindo, novamente, o modelo Walker e Plint (1992) poderíamos identificar esse pacote arenoso, como um corpo de areia de "shoreface" de mar baixo (lowstand shoreface), gerados por um processo de regressão forçada em um contexto de uma queda relativa do nivel do mar. Podese estabelecer assim o limite da seqüência meso-neo devoniana na base desse corpo arenoso, sendo que nesta posição da bacia este limite corresponderia a uma concordância correlativa.

O poço Assunção 2 teve sua perfuração interrompida em 2925 metros de profundidade, após ter penetrado cerca de 65 metros de rocha intrusiva do tipo diabásio. Entre as profundidades de 2800 e 2600 metros, o padrão da curva de raio gama deste poço pode ser correlacionado com a assinatura do intervalo entre 2100 e 2280 metros do poço Assunção 1. No entanto, o pacote sedimentar assinalado entre as profundidade de 2425 e 2600 metros, no poço 
Assunção 2, está ausente no poço Assunção 1. Para entender esta situação teríamos que imaginar um falhamento normal controlando a perda desta seção no poço Assunção 1. Neste poço na altura de 2050 metros há uma quebra no registro dos perfis elétricos e de raio gama.

Estä possibilidade de correlação, embora baseada em dados palinológicos obtidos a partir de amostras de calha, deve ser investigada mais profundamente, uma vez que este modelo implica na existência de um conjunto sedimentar de mais de 1000 metros de espessura, envolvendo sedimentos do Ordoviciano ao Eo-Devoniano; preservado no poço Assunção 2, em profundidades superiores a 2900 metros. 


\section{Capítulo 3 - ARCABouço estratigráfico}

\section{1 - Introdução}

O conjunto de dados analisados, obtidos a partir das várias seções verticais levantadas em afloramento e, sobretudo, a partir das seções de correlação de poços, possibilitou a definição de um arcabouço estratigráfico (Fig. 43) composto por quatro seqüências deposicionais de segunda ordem. As mesmas foram estabelecidas com base nos preceitos da Estratigrafia de Seqüência apresentados em Wilgus et al. (1988) e que foram consolidados, em termos de dados de afloramentos e de testemunhos, por Van Wagoner et al. (1990). O arranjo estratigráfico definido nesta pesquisa difere, parcialmente, daquele apresentado por Pereira et al (1998).

O estudo do empilhamento estratigráfico dos sedimentos da Bacia do Paraná vem sendo objeto de análise de inúmeras publicações ao longo das últimas décadas. A facilidade de acesso aos excelentes afloramentos existentes, principalmente na parte meridional da bacia, a presença de importantes escolas de geologia na sua área de ocorrência e a sua localização estratégica, englobando em seu domínio as principais áreas de desenvolvimento industrial e agrícola do país, possibilitaram que inúmeros grupos de pesquisa, tanto no âmbito acadêmico como no interior das empresas de petróleo, propusessem diferentes cartas estratigráficas para a bacia.

Um dos primeiros estudos de integração de dados feitos para a Bacia do Paraná foi realizado no âmbito da Petrobrás e apresentado por Northfleet et al. (1969). Neste estudo, os autores estabeleceram um arcabouço cronolitoestratigráfico que foi representado através de vários mapas de isópacas, os quais, em boa medida, continuam pertinentes. Ainda no âmbito desta companhia, foi desenvolvida uma revisão estratigráfica para toda a bacia, apresentada por 


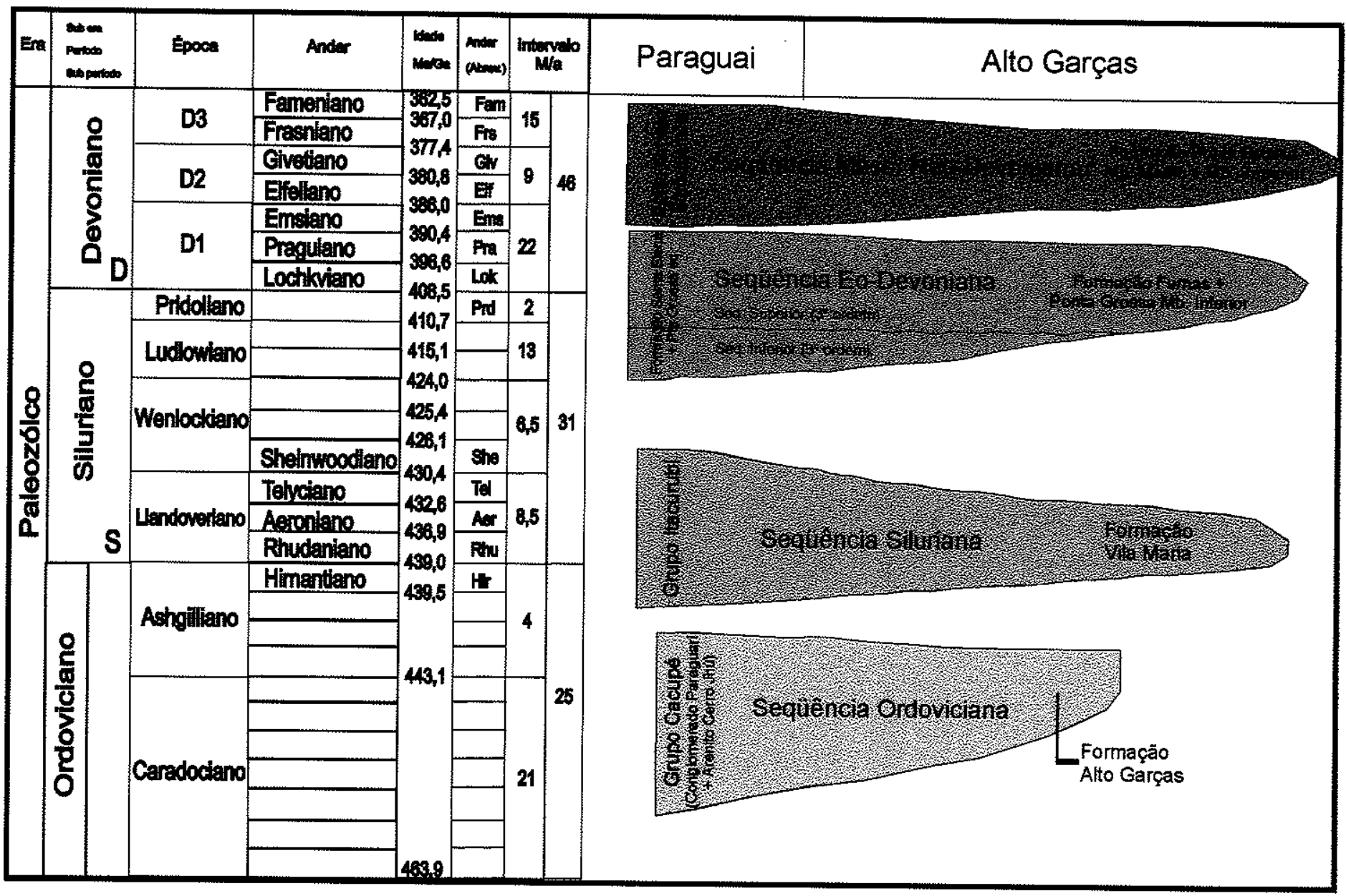

Fig. 43 - Arcabouço Cronolitoestratigráfico discutido nesta pesquisa. 
Schneider et al. (1974). Nesta revisão foram redefinidas, em termos litoestratigráficos, as unidades da bacia, sendo que o arranjo estratigráfico proposto permanece sendo utilizado nos dias de hoje. Outro estudo bastante abrangente foi realizado pela companhia Paulipetro, sendo os seus resultados divulgados em Fúlfaro et al. (1982) e Gama Jr et al. (1982). Nestes trabalhos o arranjo crono-litoestratigráfico foi apresentado sob a forma de um diagrama espaço-tempo, envolvendo os conceitos de seqüências sedimentares introduzidos na bacia por Fúlfaro \& Landin (1976) e Soares et al. (1978).

Todos os trabalhos desenvolvidos antes da década de oitenta não contemplaram a distribuição dos sedimentos pré-devonianos, que foram formalizados por Faria (1982). A primeira carta estratigráfica envolvendo estes sedimentos foi desenvolvida por Zalán et al. (1987). Nos últimos anos, várias cartas cronoestratigráficas foram estabelecidas para os sedimentos précarboníferos, ora de caráter local, Pereira (1992 e 1994), ora de cunho regional Assine et al. (1994), Milani et al. (1995), Assine (1996), Milani (1997) e Pereira et al. (1998).

A proposta apresentada neste trabalho difere das anteriores nos seguintes aspectos: 1) individualização dos sedimentos pré-devonianos em duas seqüências deposicionais, de segunda ordem (Ordoviciana e Siluriana), 2) caracterização, na seqüência Siluriana, de um conjunto arenoso transgressivo limitado pela superfície de inundação Eo-llandoveriano e litoestratigraficamente associado à base da Formação Vila Maria, 3) distribuição mais restrita dos sedimentos ordovicianos, sendo que a ocorrência dos mesmos se dá, preferencialmente, na parte ocidental da bacia, 4) subdivisão dos sedimentos devonianos em duas seqüências de segunda ordem, limitados por uma discordância regional, entre os sedimentos do eo-devoniano e aqueles do mesodevoniana e 5) estabelecimento de um plataforma rasa de deposição na porção centro-leste da bacia, no tempo Devoniano. 


\section{2 - Seqüências deposicionais de $2^{\circ}$ ordem}

Como salienta Van Wagoner et al. (1990), a aplicação da análise estratigráfica, com base na definição de seqüencias, depende: (1) do reconhecimento da hierarquia das unidades estratais, incluindo as camadas, o conjunto de camadas, as parrasseqüências, o conjunto de parasseqüências, e (2) do limite de seqüência, definido por superfícies de erosão ou não deposição e suas superfícies correlativas, com caráter cronoestratigráfico significativo. Como já visto, uma seqüência é definida por uma sucessão relativamente concordante de estratos geneticamente relacionados, limitados por discordâncias e suas concordâncias relativas (Mitchum,1977). Neste conceito de análise estratigráfica a definição do limite de seqüência tem um papel preponderante. No conceito original de Mitchum (1977), uma discordância é caracterizada por uma superfície regional de erosão ou não deposição que separa estratos mais jovens de estratos mais antigos e representa um intervalo de tempo significativo. No entanto, o conceito de discordância introduzido por Van Wagoner et al. (1988) é mais restrito, uma vez que define uma discordância como uma superfície que separa estratos mais jovens daqueles mais antigos, ao longo da qual há evidência de truncamento erosional subaéreo. Tal restrição exclui, da definição de limite, as superfícies erosivas geradas no contexto dos processos geológicos normais e associa, necessariamente, a geração da discordância a uma queda relativa do nivel do mar.

A questão da definição do limite de seqüência é provavelmente um dos mais calorosos assuntos debatidos na teoria da estratigrafia de seqüência. Segundo Liro (1997), há uma verdadeira disputa dogmática se o limite de seqüência deve ser definido por uma superfície de erosão regional associada com uma regressão relativa ("limite de seqüência do modelo Exxon"), ou pela superfície de afogamento regional ("limite da seqüência estratigráfica genética de Galloway, 1989; ou a aparentemente similar superfície de máxima inundação do modelo 
Exxon"). Esta discussão ganha maior relevância em bacias com baixo gradiente de mergulho do substrato deposicional, onde o limite entre a quebra da plataforma e o talude é discreto. Como salientam Posamentier et al. (1992), na maioria das bacias intracratônicas não ocorre uma borda de plataforma, dessa forma essas bacias podem ser definidas como bacias em rampa. Nas bacias em rampa o trato de sistema de mar a baixo é radicalmente diferente daquele caracterizado em bacias onde a quebra da plataforma / talude é bem definida (Posamentier et al., 1992; Van Wagoner et al., 1990). Em um contexto de rampa, no trato de sistema de mar baixo não irá ocorrer a deposição de sistemas turbidíticos de água profunda, sendo que o trato de sistema de mar baixo será melhor caracterizado pela ocorrência de depósitos isolados de linha de costa, associados a processos de regressão forçada (Posamentier et al. 1992; Posamentier \& Allen, 1993). Segundo Kolla et al. (1995), as condições favoráveis para a sedimentação dos depósitos de regressão forçada (bacia em rampa), especialmente para os sistemas siliciclásticos, geralmente não são favoráveis para a deposição de leques de mar baixo.

A regressão forçada é o principal mecanismo que atua na deposição das cunhas progradacionais de mar baixo (depósitos deitáicos e de linha de costa) no trato de sistema de mar baixo inicial (early lowstand systems tract Posamentier et al., 1992). A regressão forçada ocorre em condições de queda relativa do nível do mar, independente do aporte sedimentar, ao contrário da regressão normal que ocorre em condições de nível de mar alto ou estabilizado, em função da taxa de aporte sedimentar. Segundo Posamentier et al. (1992), a principal feição da regressão forçada irá ser a abrupta ocorrência de sedimentos anormalmente grosseiros ou mais proximais em ambiente marinho distal. Esses depósitos podem ser interpretados como uma linha de costa isolada desenvolvida em um contexto de mar baixo e associada com a regressão forçada. Os mesmos são normalmente caracterizados por uma base plana em contato abrupto com os sedimentos sotopostos, definindo uma discordância ou limite de seqüência. Em direção ao continente esses depósitos afinam e o limite de seqüencia é 
normalmente amalgamado com a superfície de erosáo transgressiva, formando uma superfície de erosão/transgressão, ou seja, em direção ao continente o limite de seqüência é expresso como uma superfície de ravinamento formada durante a passagem da linha de costa transgressiva. Esta superfície de ravinamento substitui a superfície subaérea de não deposição ou erosão formada inicialmente, isto é, durante à queda do nível do mar. Ainda no contexto da estratigrafia de seqüência, o limite de seqüência pode ocorrer na base dos depósitos de "shoreface". Como diagnosticado por Posamentier et al. (1992), esta superfície é discreta e realmente identificada onde os depósitos de "shoreface". possuem base plana. Dessa forma, a definição dos limites de seqüência em bacias do tipo intracratônica, dependendo da ordem da sequência que está sendo interpretada, pode ser extremamente difícil. Assim, como discutido por Liro (1997), embora muito textos tenham debatido o mérito de cada surperfície de correlação (limite de seqüência ou superfície de inundação), na prática, o geocientista deve determinar, pela observação ou motivação estratigráfica, qual superfície permite a melhor correlação em uma determinada área de estudo.

Galloway (1989) introduziu o conceito da "seqüência estratigráfica genética", que é uma unidade deposicional regressiva limitada por superfícies transgressivas. Segundo Van Wagoner et al. (1990), embora Galloway (1989) não tenha definido especificamente a mesma, ele a descreve como "um pacote de sedimento que registra um significativo episódio de anexação de uma margem de bacia e preenchimento da bacia, limitado por períodos de generalizado afogamento da margem da bacia". Os conceitos de Galloway (1989) estão baseados na concepção dos episódios deposicionais de Frazier (1974; apud Van Wagoner et al., 1990), definidos para o Quaternário tardio e controlados pelos ciclos glaciais. Esses episódios deposicionais são limitados por hiatos ou superfícies de inundação gerados durante o aumento do nivel do mar ou pela variação lateral dos lobos deltaicos A freqüência das unidades de Galloway (1989), em torno de quatro a cinco milhöes de anos, incluem algumas seqüências de terceira ordem, no sentido de Vail et al. (1977b). 
Segundo Posamentier \& James (1993), a diferença fundamental entre os conceitos da estratigrafia de seqüência e da estratigrafia genética, na visão de Galloway (1989), reside na definição de onde ocorre o início e o fim da seqüência, ou seja, quais são as superfícies limitantes das seqüências. Ou na visão de Van Wagoner et al. (1990), qual seria a melhor superfície de correlação em uma análise estratigráfica regional. Uma série de argumentos estão relatados na literatura em favor da utilização de um ou outro conceito. Como reconhecido por Posamentier \& James (1993), a superfície de máxima inundação, especialmente em novas áreas, pode ser mais facilmente identificada e sua correlação regional pode ser um bom ponto de partida do trabalho. Ainda segundo estes autores, em uma sucessão estratigráfica pontuada por discordâncias e seções condensadas, as mais significativas e reconheciveis quebras (temporal, estratigráfica, deposicional, etc) ocorrem associadas às discordâncias e não às seções condensadas.

Quando se trabalha com um arcabouço de segunda ordem é possivel se identificar, com um razoável grau de precisão, as discordâncias limitantes dos pacotes sedimentares, os quais exibem em seu interior um contínuo empilhamento sedimentar. Isto é exatamente o que se advoga no conceito de estratigrafia de sequêencia do Grupo da Exxon. No entanto, no caso da Bacia do Paraná, uma bacia em rampa, quando mudamos a hierarquia da análise estratigráfica, envolvendo seqüências de terceira e quarta ordem ou superior, torna-se difícil a definição das discordâncias e, consequentemente, sua correlação regional, prevalecendo o mapeamento das superfícies de inundação que são facilmente correlacionadas.

Em termos gerais, havendo dados suficientes e disponiveis, a análise estratigráfica deve envolver tantos os conceitos estratigráficos definidos pela escola da Exxon, como aqueles estabelecidos por Galloway (1989). Em realidade, definido $\circ$ arcabouço de segunda ordem, a análise estratigráfica caminha para a 
definição de uma estratigrafia de parasseqüencias. Como discutido por Posamentier \& James (1993), a estratigrafia de parasseqüências envolve o reconhecimento de sucessōes shallowing-upward limitadas por superfícies associadas ao incremento abrupto da profundidade da água. Para esses autores, as parasseqüências formam os blocos constituintes das unidades identificadas tanto na estratigrafia de seqüência quanto na estratigrafia genética. Em bacias intracratônicas, o empilhamento estratal em parasseqüências e conjuntos de parasseqüências é o elemento estratigráfico de mais fácil identificação em afloramentos, poços e linhas sísmicas e com maior poder de correlação regional.

As seqüências estratigráficas descritas abaixo foram definidas dentro do contexto apresentado para a análise estratigráfica, utilizando-se os conceitos da escola da Exxon. Em função da disponibilidade dos dados foram identificadas nas seqüências as superfícies transgressiva e de máxima inundação, bem como definidos os tratos de sistemas.

$\mathrm{Na}$ concepção de Posamentier et al. (1988), uma seqüência estratigráfica é composta por uma sucessão de tratos de sistemas. A composição dos tratos de sistemas presentes na seqüência é variável em função do tipo de seqüência analisada. Dois tipos de seqüências são reconhecidas (Tipo - 1 e Tipo 2) no registro sedimentar. Elas são definidas e identificadas em função (1) do arranjo dos tratos de sistemas entre os limites de seqüencia e (2) do tipo de discordância envolvido no limite de seqüência (Van Wagoner et al., 1990). Uma seqüência do Tipo - 1 é constituída pelos tratos de sistemas de mar baixo, transgressivo e de mar alto, limitada abaixo por uma discordância do tipo 1 , enquanto que uma seqüência do Tipo - 2 é composta pelos tratos de sistemas de margem de plataforma, transgressivo e de mar alto, limitada abaixo por uma discordância do tipo 2 (Van Wagoner et al., 1990 e Posamentier \& James, 1993).

Segundo Posamentier \& James (1993) uma discordância do tipo 1 se desenvolve em resposta a uma queda relativa do nivel do mar e está associada a 
uma rápida migração, em direção a bacia, do "onlap" costeiro, caracterizada pela regressão forçada e em alguns casos por incisão fluvial. Por outro lado, uma discordância do tipo 2 se desenvolve em resposta à uma desaceleração e uma posterior aceleração da subida relativa do nivel do mar. Nesta situação não ocorre uma queda relativa do nível do mar, porque a taxa da queda eustática é ligeiramente menor ou igual a taxa de subisidência da bacia. Este tipo de discordância é caracterizada por uma rápida migração, em direção a bacia, do "onlap" costeiro, sem a presença de regressão forçada e significante incisão fluvial. A diferenciação, em termos estratais, entre uma seqüência do Tipo -1 e uma do Tipo -2 , ocorre na caracterização do trato de sistema de mar baixo. $\mathrm{Na}$ seqüência do Tipo -2 este trato é substituído pelo trato de sistema de margem de plataforma, sendo que em ambos os tipos de seqüências os tratos transgressivo e de mar alto são similares. Seqüências do Tipo -2 e seqüências do Tipo -1 , depositadas em bacias em rampa, assemelham-se entre si. Nas duas estão ausentes os leques e os canyons, e seus tratos de sistemas iniciais são depositados sobre a plataforma. No entanto, na seqüência do Tipo - 2 não há registro da queda relativa do nível do mar (Van Wagoner et al., 1990).

Com base no que foi exposto todas as seqüências de segunda ordem (no sentido de Vail et al., 1977b; página 86) descritas nesta pesquisa são consideradas como seqüências do Tipo -1 .

\subsection{1 - Seqüência ordoviciana}

O registro preservado da seqüência ordoviciana é incompleto. Em superficie a mesma foi registrada, exclusivamente, em afloramentos da borda oeste da bacia. Nos poços este registro é melhor representado. Contudo, somente um pequeno número de poços atingiu esta seqüência gerando, assim, uma limitação na possibilidade de correlação lateral e, consequentemente, uma deficiência na identificação do arranjo estratal. 
A seqüência ordoviciana apresenta seu limite inferior bem definido nos poços e afloramentos. Este limite foi identificado em afloramentos da parte brasileira e paraguaia da bacia. Nessas localidades, os sedimentos posicionados na base da seqüência assentam-se em discordância angular com o embasamento. Nos poços 2-AG-1-MT, 2-DO-1-MT e no furo de sondagem 268$R 2$, os sedimentos da base da seqüência, também estão em discordância com o embasamento. O limite superior desta seqüência só foi caracterizado nos poços. Nos afloramentos esta relação não foi diretamente observada. No poço 2-AG-1MT o limite superior foi estabelecido a partir de uma mudança brusca no padrão do perfil de raio gama, associado à deposição de sedimentos conglomeráticos acima desta superfície. Nos outros dois poços onde este limite foi estabelecido, poços 2-DO-1-MT e Assunção 1, o mesmo foi caracterizado pela mudança do padrão de assinatura dos perfis. No poço Assunção 1 um espesso conjunto arenoso assenta-se sobre esta superfície marcando uma mudança no padrão de assinatura dos corpos arenosos.

A idade Ordoviciana considerada para os sedimentos é uma decorrência do posicionamento estratigráfico dos mesmos abaixo de rochas de idade Rhudaniana da Formação Euzébio Ayala. A presença de fosseis ordovicianos retrabalhados em sedimentos do Grupo Itacurubí (Y. Grahn, informação verbal) reforça a hipótese de efetivamente ter ocorrido sedimentação na bacia, neste intervalo de tempo.

O modelo de distribuição do registro preservado desta sequêencia apresenta um arranjo restrito de ocorrência (Fig. 44). O mapa de isópaca demonstra a existência de dois eixos principais de deposição / preservação dos sedimentos. Um posicionado, aproximadamente, na parte centro-oeste da bacia, com direção NNE-SSW, e um segundo, mais a sul, com direção NW-SE. Ao longo do primeiro eixo são observados dois depocentros isolados, um na parte norte da bacia em torno do poço 2-AG-1-MT, e outro envolvendo os poços Assunção 1 e 2- 

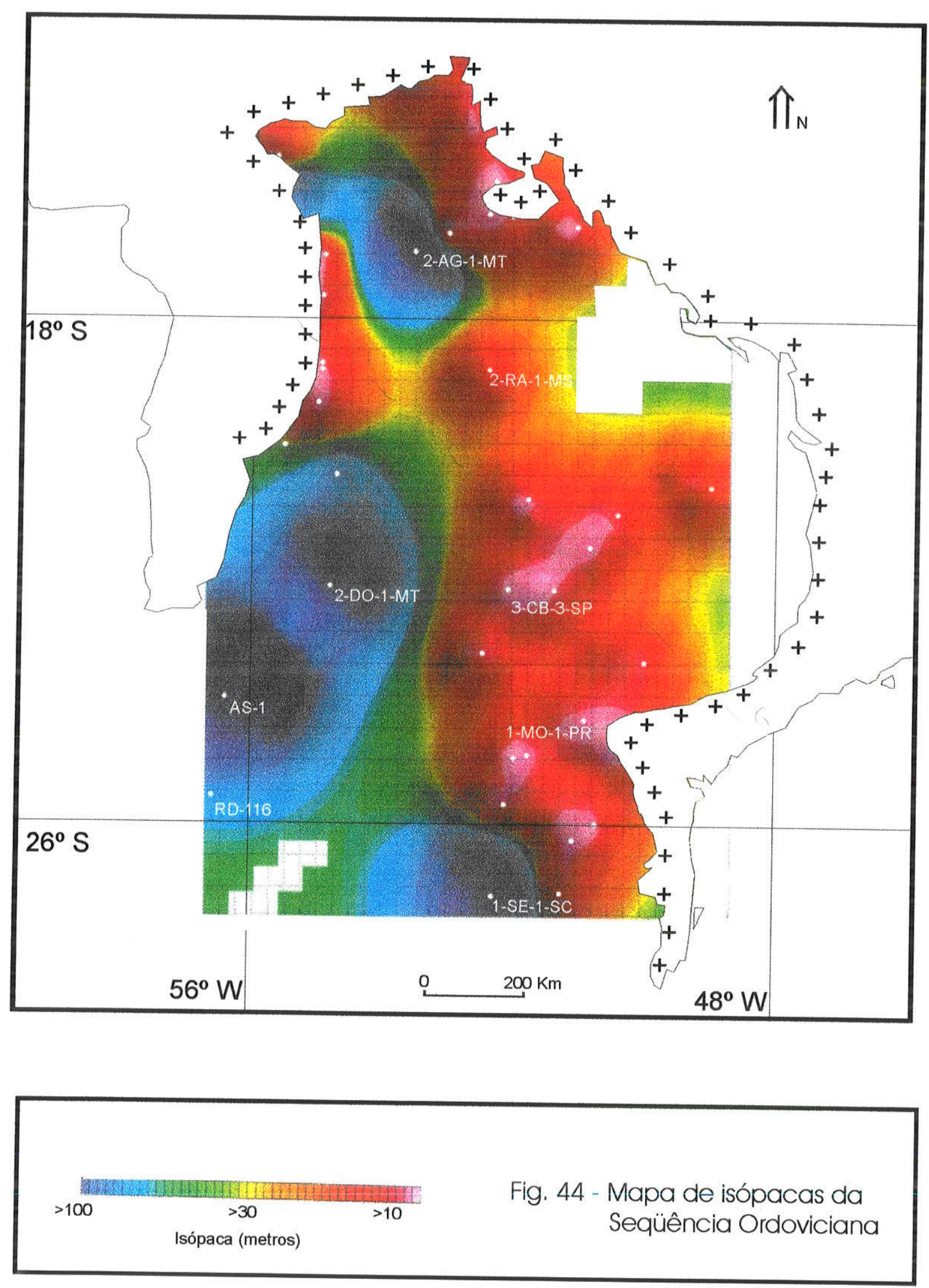
DO-1-MT. Da mesma forma, para o segundo eixo identificado são, também, diagnosticados dois depocentros, um associado ao poço 1-SE-1-SC, e outro englobando o poço Assunção 1 e o furo RD-116. A análise da distribuição dos sedimentos indica que a caracterização de depocentros isolados ao longo do eixo NNE-SSW é, provavelmente, uma resposta a atuação de eventos modificadores da sedimentação na parte norte e central da bacia. Por outro lado, o isolamento constatado para o segundo eixo, pode ser apenas um efeito da baixa densidade de dados utilizados para a montagem do mapa nesta parte da bacia.

A discussão relativa ao preenchimento da seqüência é pouco consistente, pois a densidade de informação é pequena. No eixo NNE-SSW, em seu depocentro norte, há um predomínio de depósitos, diagnosticados em afloramento e em subsuperfície, associados a ambientes de plataforma rasa (Moreira \& Borghi, 1999a). Por outro lado, no depocentro sul deste mesmo eixo, predomina uma sedimentação mais proximal onde são diagnosticadas desde condições de leque proximal até a atuação de sistemas do tipo "braid delta". Como não foi possivel definir uma superfície de correlação envolvendo estes dois depocentros, não se pode estabelecer uma relação temporal entre os diferentes ambientes de deposição. Pode-se, no entanto, especular que os depósitos de leque proximais registrados no Paraguai estariam associados a um trato de sistema de mar baixo, ligados ao início da sedimentação da bacia. Com a contínua expansão da faixa deposicional, pode ter se estabelecido uma conexão marinha, possibilitando assim o progressivo afogamento da bacia e a geração de depósitos ligados ao trato transgressivo, identificados nos sistemas do tipo "braid delta", na parte sul e nos depósitos de plataforma rasa, na parte norte. 


\subsection{2 - Seqüência siluriana}

Em termos litoestratigráfico, a seqüência siluriana envolve os sedimentos associados à Formação Vila Maria, na parte brasileira da bacia e ao Grupo Itacurubí, na sua porção paraguaia. Os sedimentos da Formação lapó, em que pese sua idade Ordoviciana, possuem uma ligação genética com os sedimentos do Eo-Siluriano. Esta associação genética é uma decorrência do controle climático exercido na sedimentação, em função dos periódicos avanços e recuos das massas de gelo, ocorridos na America do Sul, durante o NeoOrdoviciano e o Siluriano (Ross \& Ross, 1996; Caputo \& Crowell, 1985).

Quatro episódios de glaciação, no Siluriano Inferior do Brasil, foram documentados por Grahn \& Caputo (1992). Para esses autores, a idade da glaciação mais antiga é interpretada como Ashgilliana tardia e/ou Rhuddaniana inicial. O posicionamento temporal dos diamictitos, associados às glaciações que ocorreram no intervalo Ordoviciano / Siluriano, é uma questão polêmica nas pesquisas sobre o Gondwana ocidental (Boucot, 1999; Scotese, 1999). Pelos dados aqui apresentados podemos estabelecer a existência de duas fases glaciais neste período. Uma glaciação inicial, de idade Eo-Ashgilliana (sensu, Ross \& Ross, 1988), registrada nos sedimentos da Formação lapó, e uma segunda glaciação, de idade Eo-Rhuddaniana, registrada nos diamictitos da Formação Vila Maria. A primeira, em função das características sedimentológicas (Faria \& Pereira, 1994) e do estado juvenil do embasamento, é associada a uma glaciação de altitude, e a segunda de caráter glacio-marinho, envolvendo condições desde margem glacial até depósitos marinhos distais sem influência glacial (Pereira, 1998). Os dois eventos diagnosticados na bacia marcam quedas eustáticas do nível do mar que podem ser correlacionadas à curva de variação do "onlap" costeiro estabelecida por Ross \& Ross (1988).

A seqüencia siluriana possui superficies limitantes mapeáveis e de fácil observação em toda a bacia. Exceção ocorre na parte paraguaia, onde em 
superfície, os limites desta seqüência não estão bem definidos. O limite inferior está marcado nos afloramentos da borda leste da bacia e nos poços da parte central da mesma, onde os estratos assentam-se diretamente sobre o embasamento. $\mathrm{O}$ contato com os sedimentos da seqüência ordoviciana é também claramente discordante, como observado no poço 2-AG-1-MT e identificado por Borghi \& Moreira' (1998), em afloramenrtos, na região da Chapada dos Guimarães. O contato superior com os sedimentos da seqüência eo-devoniana é francamente discordante marcado por uma expressiva perda de parte da seção sedimentar siluriana. Em alguns afloramentos a caracterização dessa superfície de discordância pode ser polêmica (ver discussão detalhada em Pereira, 1998), uma vez que a mesma ocorre entre corpos arenosos com aspectos petrográficos similares.

Uma idade Siluriana (Llandoveriana) foi definida para esta seqüência. A partir do biozoneamento estratigráfico realizado nesta pesquisa pôde-se caracterizar uma idade mínima Rhuddaniana para os sedimentos posicionados abaixo da superfície transgressiva; uma idade Aeroniana para esta superfície e uma idade Telychiana, para os sedimentos regressivos posicionados acima da mesma.

A distribuição regional dos sedimentos associados à seqüência siluriana (Fig. 45) demonstra uma expansão da área de deposição dos sedimentos, em relação à seqüência anterior. Os sedimentos distribuem-se por uma ampla área da bacia, estando o depocentro principal posicionado na parte sul. Há uma diminuição progressivo da espessura da seqüência no sentido nordeste, que pode em parte representar uma perda de seção mais expressiva na zonas de borda da bacia. Entretanto, este sentido também coincide com a tendência do recobrimento progressivo (onlap) exercido pelo afogamento eollandoveriano, a partir de zonas de maior profundidade na porção paraguaia da bacia até situações de água rasa, nas zonas periféricas da mesma. A restrição na área de deposição observada na parte norte da bacia é produto da perda total ou parcial, por erosão, dos sedimentos silurianos. A subdivisão em três depocentros 


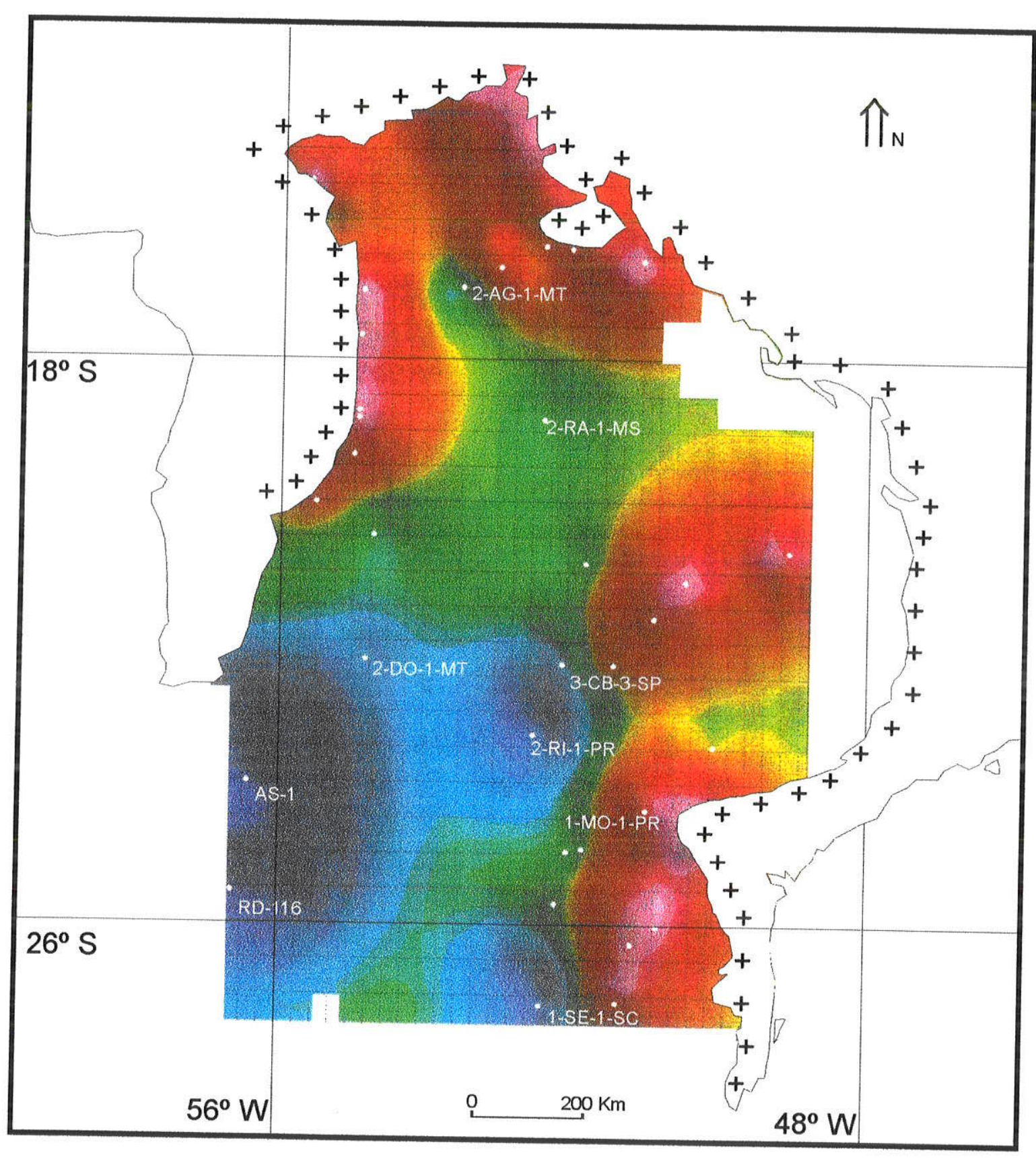

Fig. 45 - Mapa de isópacas da Seqüência Siluriana 
na parte sul pode ser apenas um efeito da confecção do mapa de isópaca. 0 mapa de isópaca representando o somatório das espessuras das seqüências ordoviciana e siluriana (Fig. 46) demonstra, explicitamente, que a ausência de sedimentos pré-devonianos na região oeste-noroeste da bacia é decorrência da posterior erosão dos mesmos.

A expansão verificada na bacia insere-se no contexto dos aumentos globais do nivel do mar que ocorreram durante o Silurianao. Segundo Johnson (1996) pelo menos oito eventos de aumento do nivel do mar, em termos globais, tiveram lugar durante o período Siluriano, sendo que quatro deles, ocorridos durante a época Llandoveriano, estão fortemente associados a episódios interglaciais na região brasileira do Gondwana. Para Ross \& Ross (1996) as fases transgressivas do início do Siluriano, no Rhuddaniano e no Aeroniano, observadas em bacias americanas e européias, são limitadas e a distribuição dos sedimentos indica deposição em vales e baixos deposicionais sobre uma superfície topográfica pós-Ordoviciana.

Na Bacia do Paraná, o evento transgressivo Aeroniano possui um caráter global, podendo ser correlacionada por toda a bacia, como também em outras bacias do Gondwana oriental. No furo de sondagem RD-116 a superfície transgressiva Aeroniana está marcada por uma brusca mudança no perfil de raio gama, em torno de 240 metros de profundidade, onde podem ser observados depósitos oolíticos ferruginosos.

Oólitos ferruginosos são descritos, ao longo de uma ampla área de ocorrência no sudoeste europeu, associados à seqüências ordovicianas, em contexto de plataforma (Young, 1992). Em todos os depósitos analisados por Young (1992) estes sedimentos são posicionados em um contexto transgressivo, relacionada ao aumento do nível do mar e posicionados próximo à superfície de inundação máxima, em um arcabouço de seqüência de segunda ordem. Em algumas regiões gondwânicas, os oólitos ocorrem diretamente sobre os depósitos 


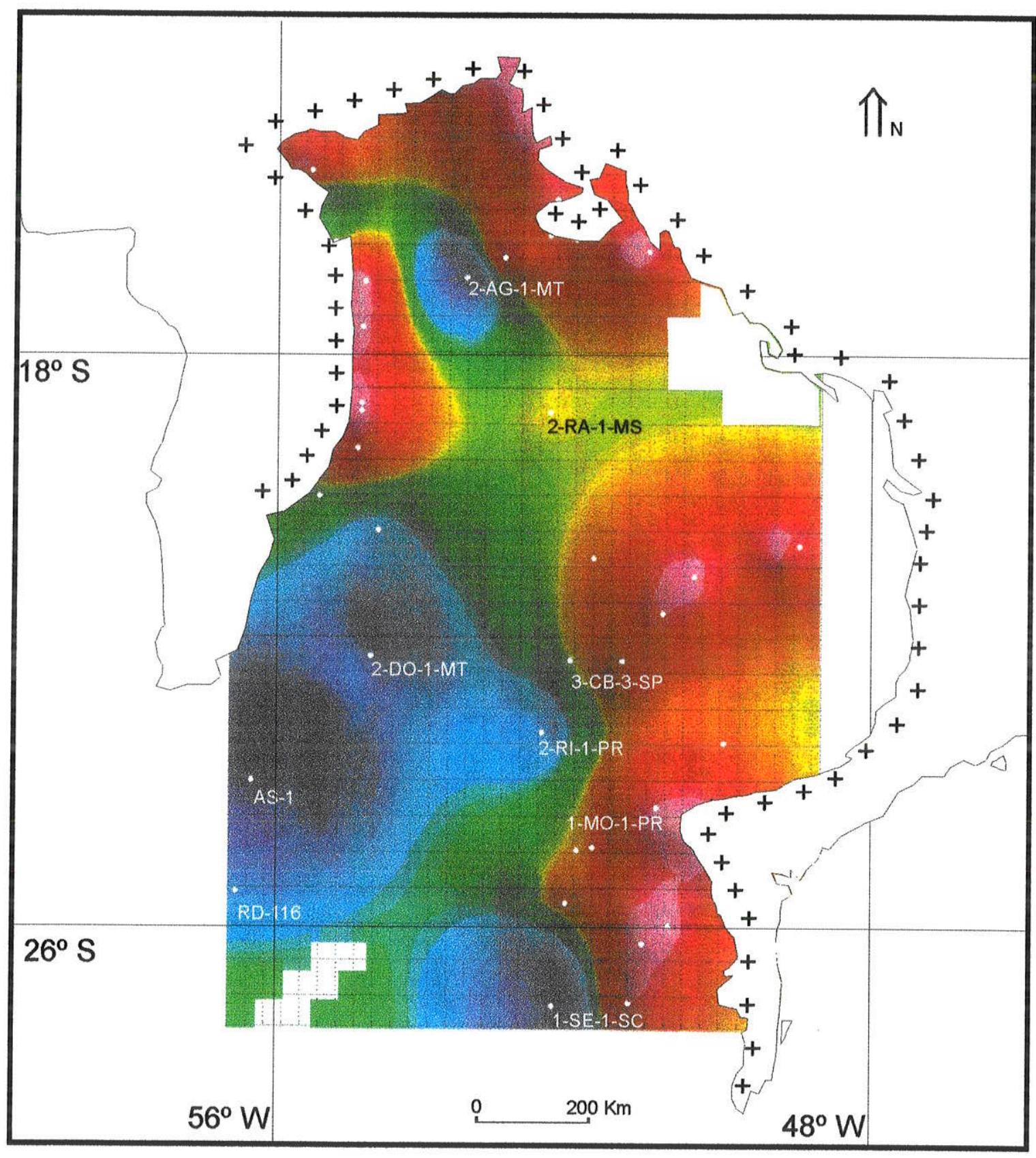

$>250$ $>90$ $>40$ Isópaca (metros)

Fig. 46 - Mapa de isópacas das Seqüências Ordoviciana e Siluriana 
de mar baixo. Segundo Sturesson et al. (1999), na literatura recente o modelo genético mais freqüente para o formação desses depósitos inclui uma associação entre $o$ transporte fluvial até o mar dos produtos do intemperismo laterítico e a variação relativa do nível mar. No entanto, esses autores levantam a hipótese de uma origem vulcânica para os depósitos oolíticos e os descrevem no interior de ciclos de shallowing-upward limitados por superfícies transgressivas.

A fim de caracterizar as superfícies de inundação máxima das quatros seqüências deposicionais definidas foram realizadas análises geoquímicas visando à determinação do teor de carbono orgânico total (COT) dos sedimentos. O estudo geoquímico realizado no furo RD-116 possibilitou a definição da superfície de inundação máxima da seqüência siluriana neste furo (Fig. 47). O padrão de variação observado para os teores de carbono orgânico total permite visualizar uma tendência transgressiva marcada por ciclos limitados por superfícies de inundação marinha, definidas pelos teores mais altos de carbono orgânico. Esta tendência termina no intervalo em torno das profundidades de 210 e 235 metros, onde se registra a superfície de máxima inundação assinalada por valores mais elevados de COT. Após esta superfície a tendência se reverte, ou seja, instala-se um contexto regressivo, marcado pelo decréscimo contínuo dos valores de COT.

A superfície de máxima inundação é tipificada neste furo por folhelhos escuros laminados e bioturdados e está posicionada a cerca de 20 metros da superfície transgressiva. Os depósitos de trato de mar baixo, de maneira geral, estão associados a depósitos gerados por uma composição de fluxos trativos e gravitacionais no contexto de uma progradação deltaica, em uma posição periglacial. Por vezes, esses depósitos podem estar diretamente associados à dinâmica glacial, como observados em afloramentos na parte norte da bacia, onde são descritos diamictitos gerados em condições predominantemente subglaciais. Nos poços os depósitos associados ao trato 


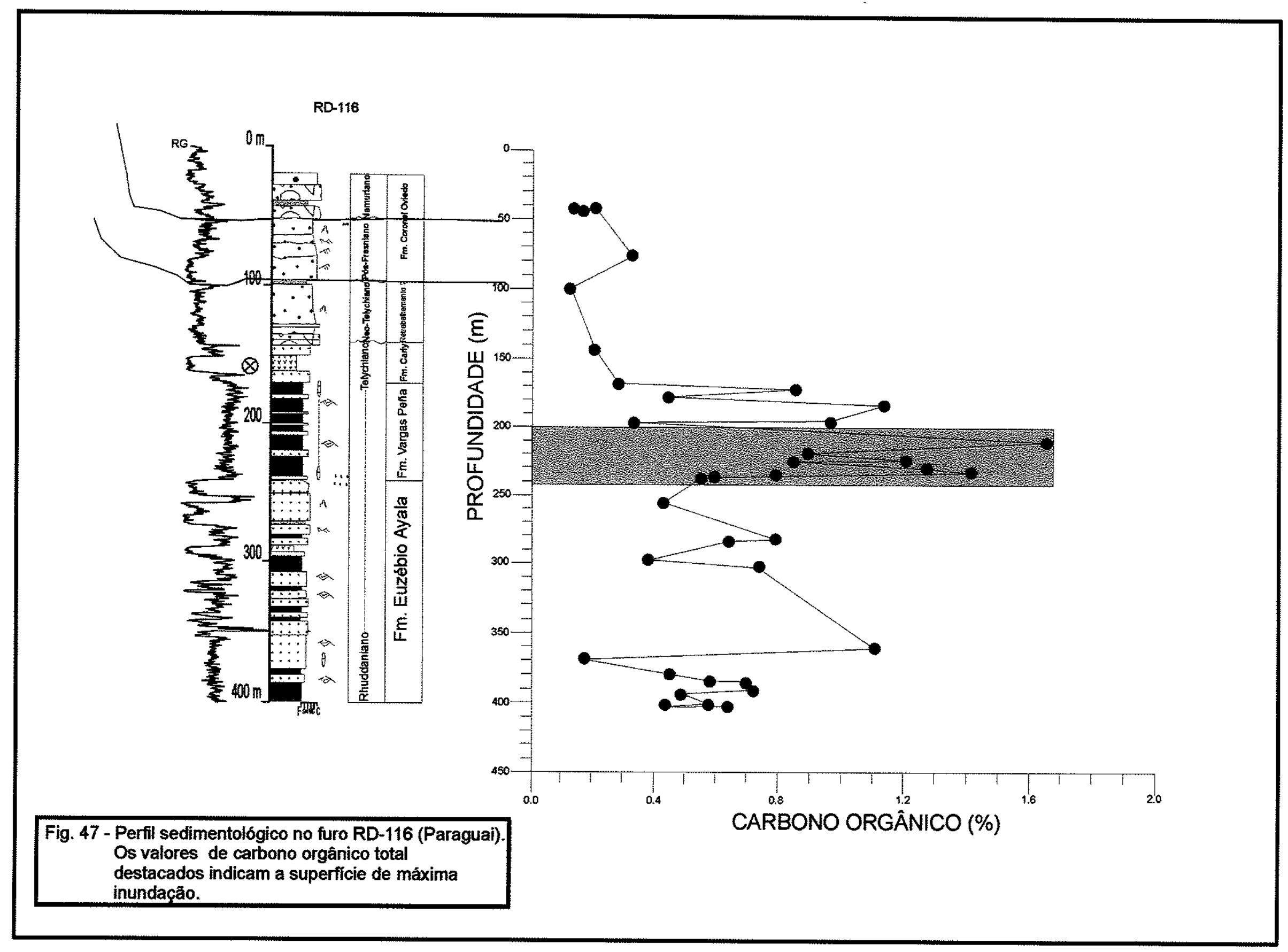


transgressivo são deigados e de difícil mapeamento. Em afloramento esses depósitos são caracterizados por sedimentos gerados em ambiente marinho rasa de alta energia, marcada pela presença da icnofácies Skolithos e em alguns casos, por influência glacial, podem ocorrer ainda conglomerados e ritmitos com seixos caídos, associados a este trato. O trato de sistema de mar alto é reconhecido em diversas posições da bacia pelo empilhamento de ciclos de engrossamento para o topo, agrupados em um arranjo geral progradacional regressivo. Em termos facilógicos, estes ciclos são compostos pelas associações de fácies III e IV definidas em afloramentos por Pereira (1998). Essas fácies foram geradas sob condições deposicionais estabelecidas por uma progressiva implantação de condições plataformais cada vez mais rasa, sob a influência da ação de ondas de tempestades e, por vezes, controladas pela ação de marés.

\subsection{3 - Seqüência eo-devoniana}

A definição de uma seqüência de segunda ordem envolvendo os sedimentos da Formação Furnas e a parte inferior da Formação Ponta Grossa está baseada na caracterização de uma superfície de discordância entre os sedimentos dos membros inferior e médio da Formação Ponta Grossa. Como visto, este limite está bem definido em subsuperfície e nos afloramentos, na parte norte da bacia, em termos estratigráficos e bioestratigráficos. Na parte central da mesma esta situação também é observada pela mudança abrupta no padrão de raio gama dos folhelhos associados a parte inferior da Formação Ponta Grossa, a qual está associada à uma significativa mudança na idade dos sedimentos. A perda de seção contida nesta superfície pode ser da ordem de $7 \mathrm{Ma}$, em função da ausência, na bacia, de sedimentos com idades Neo-Praguiana e Eo-Emsiana (Grahn, 1999).

Dessa forma, esta sequeencia tem como limite superior a superficie acima descrita e como limite inferior a discordância da base da Formação Furnas, 
facilmente reconhecida em afloramentos nas bordas da bacia, onde encontra-se sobreposta, de forma plana, sobre as rochas das diferentes unidades que compõem o embasamento da bacia, bem como sobre os sedimentos silurianos da mesma. Esta seqüência apresenta uma abrangência estratigráfica similar à Formação Furnas. A mesma demonstra uma distribuição regional bastante regular, traduzida por uma uniformidade no empilhamento estratigráfico e por uma relativa similaridade faciológica. Uma visão desta distribuição regional para o tempo Lochkviano (Fig. 48) demonstra uma bacia em rampa com um mergulho deposicional principal direcionado para WSW.

A superfície transgressiva é claramente definida e está posicionada na base da Formação Ponta Grossa. A mesma é representada pelo truncamento dos depósitos arenosos costeiros da Formação Furnas, por depósitos tempestíticos da base da Formação Ponta Grossa, na borda leste da bacia e por pavimentos conglomeráticos, que marcam o contato destas formações, em pontos localizados, na parte norte da mesma. Os resultados bioestratigráficos alcançados na datação dos folhelhos basais da Formação Ponta Grossa demonstram que o incremento relativo do nivel do mar, representado pela superfície transgressiva, possui uma idade progressivamente mais jovem para leste. No poço Assunçăo 1 , no sudoeste da bacia, a idade desta superfície é Eo-Lochkoviana e no poço 2-RI1-PR a mesma superfície possui uma idade Lochkoviana. $\mathrm{Na}$ região de Amorinópolis (GO), extremo nordeste, os folhelhos imediatamente acima dos conglomerados possuem uma idade Praguiana. Esta última idade foi obtida com base em quinozoários, enquanto que as anteriores foram estabelecidas com base em esporos.

A superfície de inundação máxima desta seqüência está contida nos folhelhos, associados às camadas inferiores da Formação Ponta Grossa, que registram a implantação definitiva de condições marinhas na bacia no tempo Eodevoniano (Praguiano). Este afogamento representa um marco global no registro estratigráfico da bacia, sendo caracterizado nos poços por uma abrupta mudança 


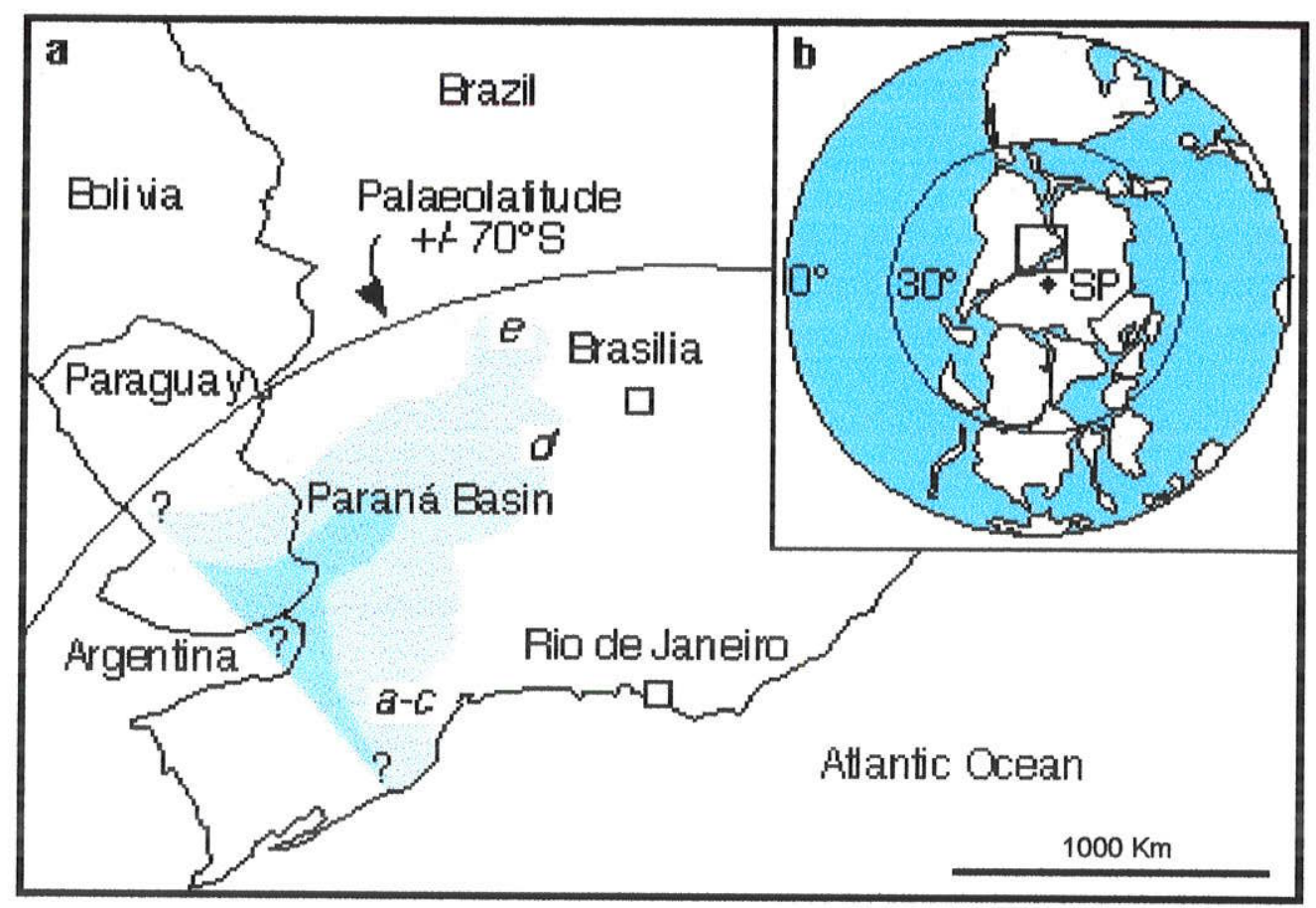

Fig. 48 - Esboço paleogeográfico para a Bacia do Paraná, no tempo Lochkoviano, extraído de Gerrienne et al. (submetido, 1999).

(a-e) Ocorrência de plantas vasculares eo-devonianas. a-c: Área do Arco de Ponta Grossa

d: Amorinópolis (GO)

e: Chapada dos Guimarães

$\square$ depósitos costeiros a marinho raso

$\square$ depósitos de shoreface inferior a offshore 
no padrão dos perfis. Em afloramento, esta superfície está caracterizada faciológicamente por folhelhos escuros laminados e bioturbados. De forma subordinada, ocorrem estruturas tipo wavy / linsen demonstrando uma deposição em condições marinhas de costa-afora (offshore).

A caracterização geoquímica dessa superfície, em termos do teor de carbono orgânico total (COT) dos sedimentos (Fig. 49), foi realizada em um seção aflorante no município de Rio Verde de Mato Grosso (MT). A mesma demonstrou uma variação cíclica dos teores, definindo sucessivas superficies de inundação marinha, que limitam pacotes sedimentares com cerca de 2 metros de espessura. As superfícies apresentam uma ligeira tendência de diminuição dos valores de COT (entre 0,8 e $1,0 \%$ ) para o topo da seção. Nesta seção o registro não é completo, pois posiciona-se no topo da mesma o limite superior da seqüência. Os valores mais elevados de COT podem representar, nesta localidade, a superfície de inundação máxima.

No modelo estratigráfico estabelecido para esta seqüência, os sedimentos relacionados à Formação Furnas estariam associados a um trato de sistema de mar baixo (TSMB). Com base nos conceitos da estratigrafia de seqüência, aplicados a bacias em rampa, esta associação é um paradoxo, uma vez que estariamos posicionando um pacote com cerca de 300 metros de espessura no TSMB. É possivel que este paradoxo resida na dificuldade em se estabeler um fatiamento bioestratigráfico para esta unidade.

Nos últimos anos as camadas mais superiores da Formação Furnas vêm sendo datadas por diferentes ferramentas estratigráficas. A mais recente datação indica uma idade Eo-Lochkoviana (Gerrienne et al., submetido; 1999) para estas camadas. Esta idade estabelece uma contemporaneidade deposicional com os sedimentos, equivalentes à Formação Ponta Grossa, descritos no poço Assunção 1. No entanto, para a base desta unidade não foram realizadas datações. As idades apresentadas na literatura, para esse intervalo, são 


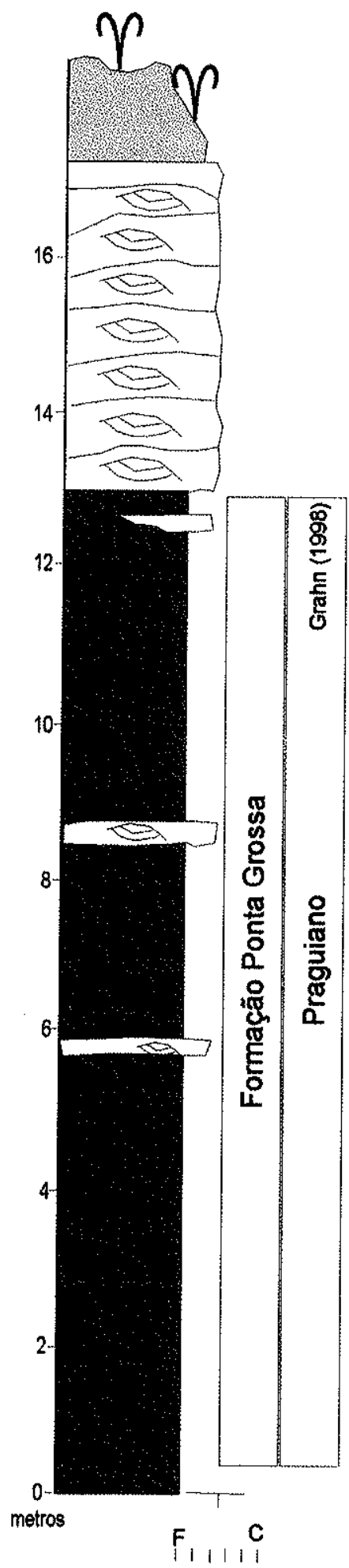

Fig. 49 - Perfil sedimentológico na região de Rio Verde de Mato Grosso (MT).

Os valores de carbono orgânico total destacados indicam sucessivas superfícies de inundação marinha limitando pacotes sedimentares com 2 metros de espessura.

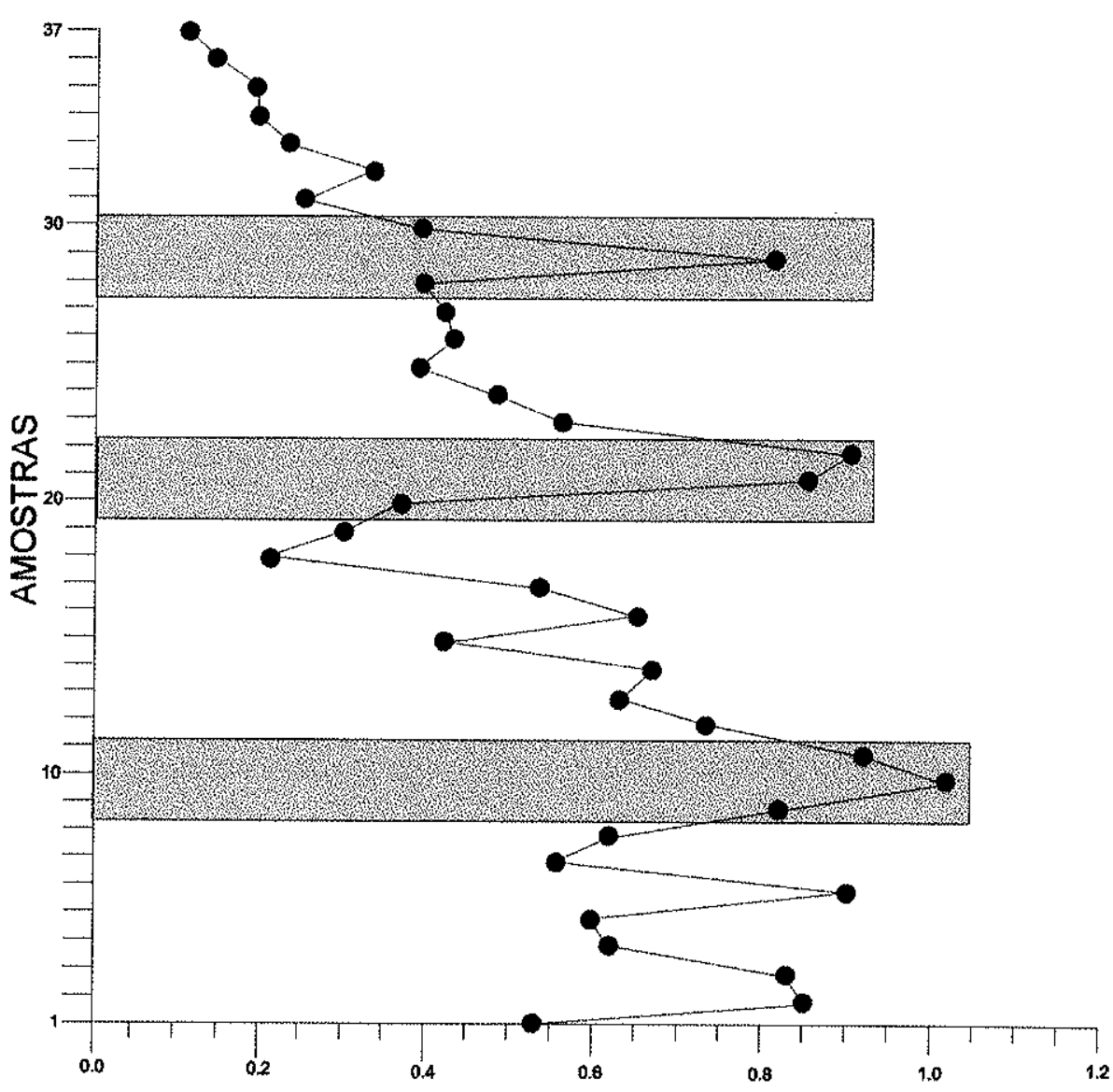

CARBONO ORGÂNICO (\%) 
resultantes dos modelos estratigráficos elaborados pelos diferentes autores, não existindo também um consenso para as mesmas. Milani (1997) indica que o início da sedimentação Furnas ocorreu muito provavelmente próximo ao limite arbitrado entre o Siluriano e o Devoniano (410 Ma). Bergamaschi (1999) posiciona a base da Formação Furnas no Pridoliano, embora considere, também, a possibilidade de uma idade Ludilowiana para esta base. Para Grahn (1999) a porção inferior da Formação Furnas poderia, em parte, ter uma idade Lochkoviana.

Como discutido anteriormente, a seqüência eo-devoniana pode ser dividida em duas outras seqüências de $3^{\circ}$ ordem nos moldes propostos por Milani (1997). A primeira seqüência seria marcada na base pelo estaqueamento de pacotes arenosos, que progressivamente afinam e diminuem de espessura em direção a superfície de inundação máxima, posicionada no domínio central da unidade. Esta superfície de inundação máxima não está datada. A mesma foi posicionada por Milani (1997) no eo-devoniano, mas, em função dos dados ora apresentados, a mesma poderia ser posicionada no Siluriano. A segunda seqüência, por sua vez, estaria posicionada no terço superior da Formação Furnas, sendo sua base marcada por uma sucessão de corpos arenosos espessos, definindo uma incisão de pequena magnitude gerada provavelmente por uma queda relativa do nível do mar.

Correlacionando o modelo estratigráfico descrito com as curvas de variação do nivel do mar, propostas para o Siluriano por Johnson (1996) e Ross \& Ross (1996), poderiamos associar esta superfície de inundação ao evento de aumento do nível do mar ocorrido no Ludlowiano superior. Em decorrência, a base da seqüencia de terceira ordem mais antiga estaria posicionada no Eo-Ludlowiano e a base da seqüência subseqüente no Pridoliano. Como o arcabouço bioestratigráfico para este conjunto é frágil, não há resolução para se definir a magnitude dos hiatos envolvidos. Por essa proposta estratigráfica, o intervalo de tempo envolvido na deposição dos sedimentos da parte inferior da Formação Furnas, está contido em um ciclo de segunda ordem e teria início no Eo- 
Ludlowiano. Esta hipótese estratigráfica poderia minimizar o paradoxo colocado, uma vez que parte dos sedimentos da seqüência eo-devoniana, pertenceriam de fato a uma outra seqüência de mesma hierarquia.

\subsection{4 - Seqüência meso / neo-devoniana}

A seqüência meso / neo-devoniana é composta, em sua base, pelos sedimentos do membro médio da Formação Ponta Grossa. Os mesmos são constituídos por arenitos finos a médios, por vezes grossos, vermelhos, com estratificação cruzada por onda, depositados sobre a forma de estratos tabulares e organizados em ciclos de engrossamento para o topo. Esses sedimentos, na parte norte da bacia, são caracterizados por espessos pacotes arenosos que sobrepõem, em discordância, os sedimentos do eo-devoniano. Em sua quase totalidade, esse pacote arenoso está contido no trato de sistena transgressivo, com exceção de alguns corpos arenosos com aspectos sedimentológicos específicos que foram associados ao trato de sistema de mar baixo (ver discussão em 2.5.4). Esse conjunto arenoso foi depositado em condições de plataforma marinha rasa sob a ação de ondas de tempestades.

$\mathrm{Na}$ parte sul da bacia, sedimentos cronocorrelatos estão presentes no intervalo Efeliano (120-220 metros) da seção colunar Tibagi - Telêmaco Borba descrita por Bergamaschi (1999). Este autor caracteriza este intervalo pelo aumento na proporção de sedimentos arenosos em relação aos intervalos devonianos mais antigos. No intervalo Efeliano, Bergamaschi (1999) descreve a presença de estratos de arenito fino com laminação cruzada por onda e estratificação cruzada hummocky e também por estratos de arenito médio de geometria sigmoidal, bioturbados, com abundantes fragmentos de Spongiophyton e que exibem estratificação cruzada de pequeno porte e estratificação cruzada cavalgante. Ainda segundo 0 autor neste intervalo ocorrem também corpos arenosos de base abrupta e ciclos de "coarsening - shallowing upward", que 
foram associadas a uma deposição por progradação do "shoreface", no contexto de um trato transgressivo. Nesta parte da bacia a definição do limite inferior da seqüência meso / neo-devoniana, em afloramento e poços, é menos evidente. No entanto, o mesmo pode estar representado nesta área pela base da "Seqüência D" (terceira ordem) definida por Bergamaschi (1999).

O aumento na razão areia / argila, que ocorre na bacia neste intervalo de tempo, está registrada no mapa de porcentagem de areia da Formação Ponta Grossa (Fig. 50), elaborado por Northfleet et al. (1969). Embora, tenha ocorrido nos últimos anos um aumento na base de dados, através de novas perfurações, os aspectos gerais da distribuição dos sedimentos apresentados no mapa estão corretos. O mapa demonstra uma tendência do aumento desta razão nas zonas marginais da bacia, com uma concentração das areias nas regiões centro-leste e nordeste da mesma. Este arranjo marca a distribuição do trato de sistema transgressivo. A progressiva subida do nível do mar gera espaço, em um contexto transgressivo, para que se depositem ciclos de "coarsening - shallowing upward". Estes ciclos, PAC'S - no sentido de Goodwin \& Anderson (1985) ou parasseqüências - no sentido de Van Wagoner et al. (1990), representam internamente pequenas progradações do shoreface superior sobre condições de plataforma mais distal.

Estas subidas relativas do nível do mar produzem várias superficies de inundação na bacia. Buscando caracterizar, entre as mesmas, qual define a superficie de máxima inundação, seções aflorantes foram estudadas, em termos de teores de carbono orgânico total. Uma seção, envolvendo os sedimentos do Neo-Emsiano, foi realizada na região de Baliza (GO) (Fig. 51). O maior valor para o teor de carbono orgânico total ( $2 \%$ ) foi registrado em folhelhos e siltitos escuros, laminados e bioturbados. Os mesmos estão inseridos entre pacotes de arenitos finos e siltitos com estratificação cruzada por onda, arranjados sob a forma de turbiditos oscilatórios, depositados em condições "proximal inner shelf zone" (Pereira, 1992). 


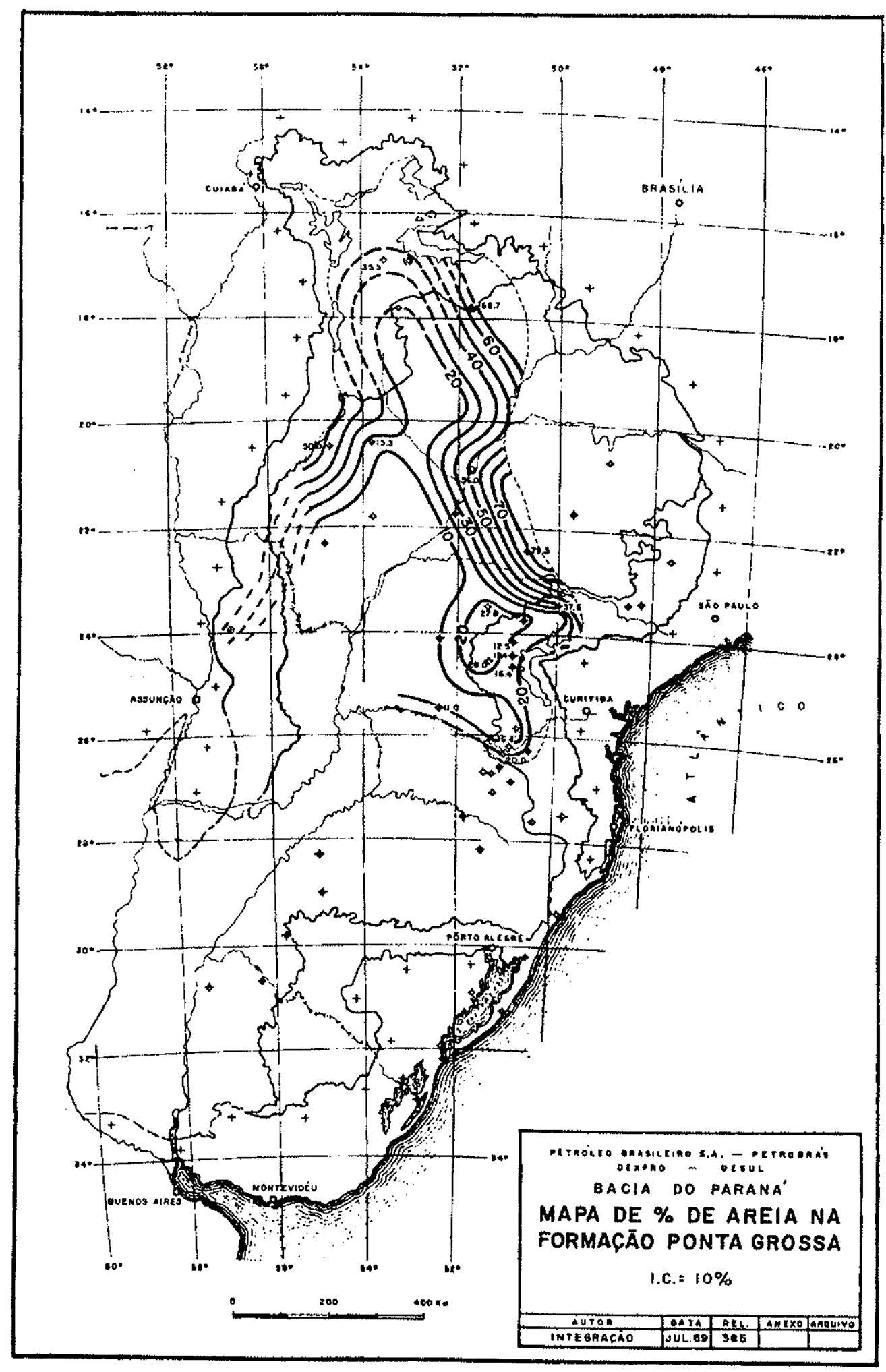

Fig. 50 - Mapa de \% de areia na Formação Ponta Grossa, modificado de Northfleet et al. (1969). 


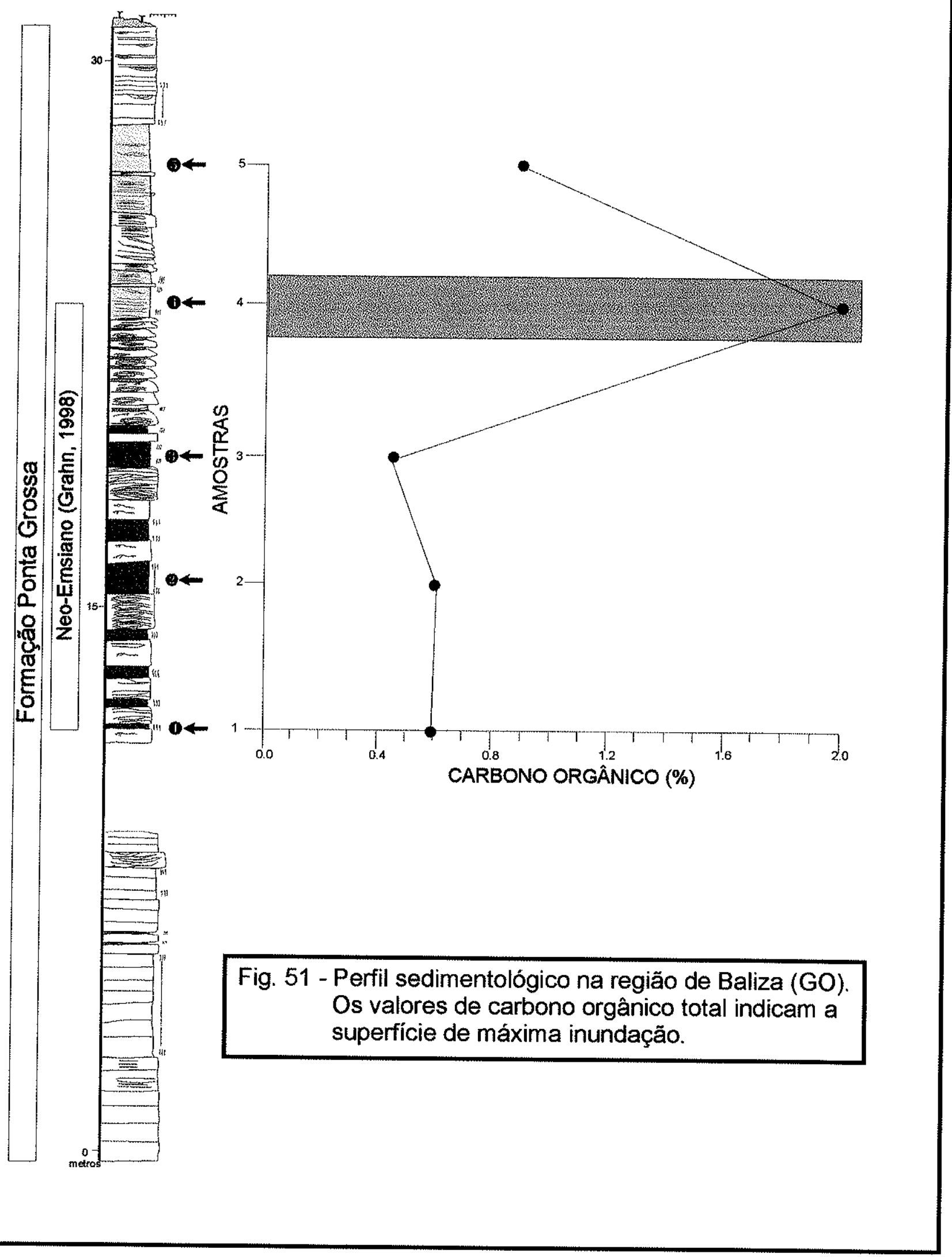


O contínuo aumento no nivel do mar yerou na bacia a implantação de condições deposicionais cada vez mais distais. No limite Efeliano / Givetiano, esta dinâmica produz uma mudança brusca no padrão sedimentar, demonstrado pelo afogamento dos depósitos arenosos do membro médio da Formação Ponta Grossa e a deposição de uma seção composta por folhelhos e siltitos intensamente bioturbados (Fig 28a - B), litoestratigraficamente associada ao membro superior desta unidade. Esta nova inundação marinha de grande magnitude repete o processo observado para o Eo-Devoniano, gerando um amalgamento dos depósitos transgressivos.

O progressivo afogamento da plataforma possibilita o estabelecimento do trato sistema de mar alto, caracterizado por depósitos marinhos de costa-afora influenciados pela ação de tempestades. A superfície de inundação máxima, resultante desse processo, foi posicionada em sedimentos do frasniano inferior, a partir dos teores de carbono orgânico total encontrados na seção Dom Aquino (MT) (Fig. 52). Nesta seção, o limite Givetiano / Frasniano foi estabelecido por Oliveira (1997) e Grahn (1998), a partir de seguras bases palinológicas.

A distribuição dos teores de carbono orgânico total demonstra discretos valores para os sedimentos do givetiano superior e do frasniano inicial. A cerca de 20 metros acima do limite Givetiano / Frasniano, inicia-se um consistente aumento nos teores, culminando, 10 metros acima, com o registro de valores em torno de $4 \%$ de carbono orgânico total, em folhelhos negros, laminados, por vezes papiráceos. Esses expressivos valores, obtidos em amostras de afloramento, marcam provavelmente a superfície de máxima inundação da seqüência mesoneodevoniana.

Os valores obtidos nesta seção são os maiores encontrados para toda o conjunto devoniano analisado. Este dado possibilita definir que em um arcabouço estratigráfico de menor hierarquia, envolvendo toda sedimentação 


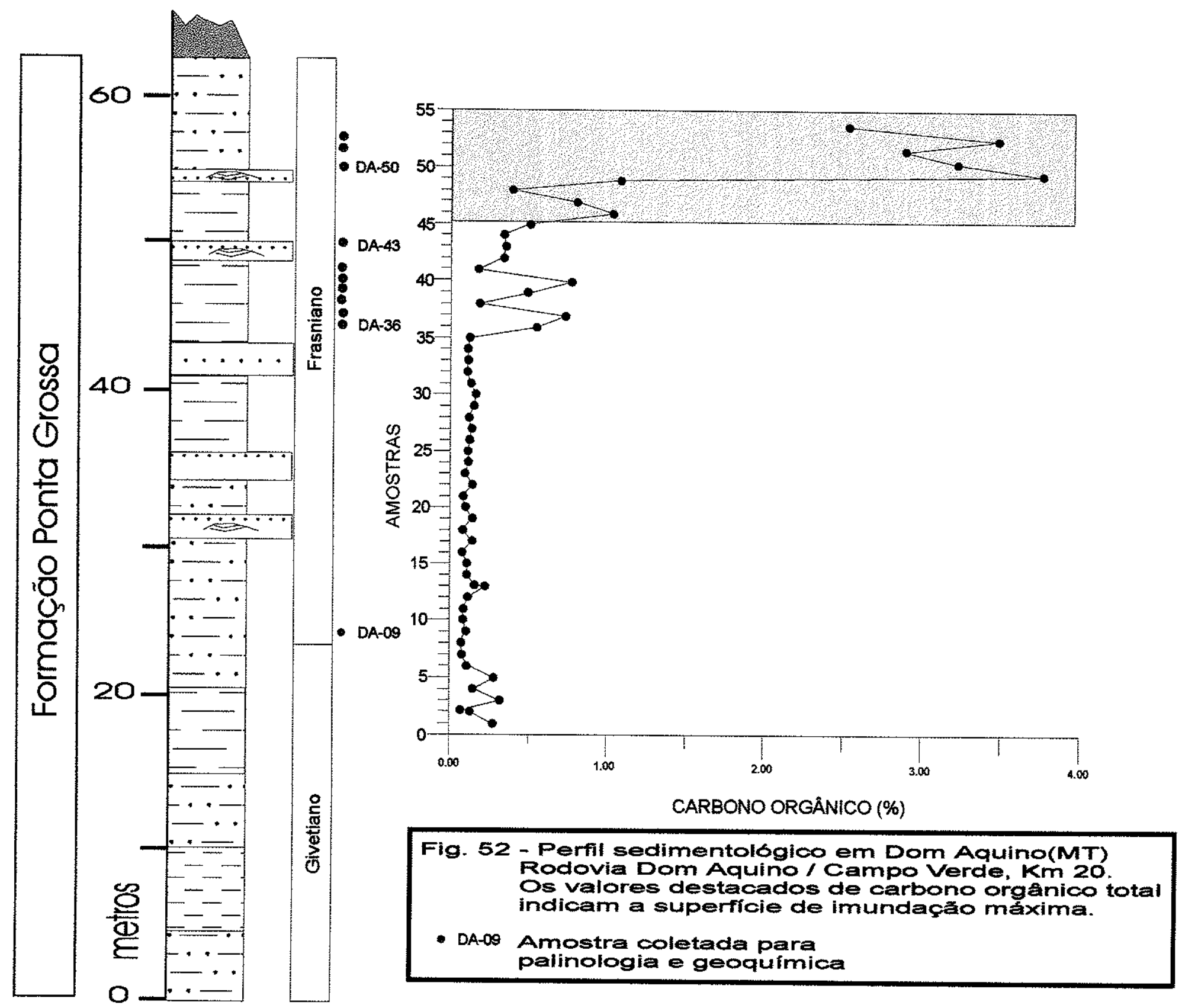


devoniana, a superfície de inundação máxima estaria posicionada em folhelhos do frasniano inferior, quando ocorreria, então, a máxima expansão da bacia. 


\section{Capitulo 4 - ARCabouço Tectônico}

\section{1 - Origens das bacias intracratônicas}

$\mathrm{Na}$ classificação de bacias proposta por Bois et al. (1982; In Leighton, 1990), existem dos tipos de bacias intracratônicas: (1) aquelas que recobrem o embasamento cristalino e (2) aquelas que recobrem bacias de outras categorias previamente formadas. As mesmas são agrupadas na classe de bacias cratônicas ou de plataforma, marcadas por um baixa taxa de sedimentação (Classe 1). Os parâmetros básicos utilizados para a classificação e subdivisão das bacias são geotectônicos, tendo as bacias intracratônicas uma ocorrência não associada aos cinturões móveis. Segundo, Leighton (1990) o uso do termo bacia cratônica, no sentido mais geral, é reservado para todas as bacias posicionadas originalmente sobre o cráton. Desse modo, o espectro das bacias cratônicas varia de ambientes pericratônicos, onde as bacias são formadas junto ou próximo a margem cratônica, até as bacias formadas, efetivamente, no interior do cráton.

A definição de Klein (1995) para as bacias intracratônicas é convergente com aquela apresentada por Bois et al. (op. cit.). Para o autor, as bacias intracratônicas ocorrem no interior continental, distante das margens das placas, assentadas sobre crosta continental, e em muito casos, estão também sobrepostas a rifts abortados ou fósseis. Ainda para Klein (1995), a evolução dessas bacias envolve uma combinação, e sucessão, de processos ligados a formação da bacia, os quais incluem extensão continental, subsidência termal sobre uma área ampla, e reajustamentos isostáticos tardjos.

Discussões acerca dos processos formadores das bacias intracratônicas vêm sendo desenvolvidas por várias décadas sem, no entanto, ocorrer um consenso entre os pesquisadores sobre a gênese das mesmas. 
Leighton \& Kolata (7990) relacionam seis possíveis mecanismos envolvidos na formação e desenvolvimento desse tipo de bacia: (1) soerguimento termal seguido de erosão subaérea e subsidência, (2) estiramento e afinamento da crosta continental, (3) sobrecarga tectônica na margem da placa, (4) mudanças de fase e sobrecarga subcrustal, (5) deflação e flambagem da crosta e (6) subsidência relacionada a transmissão horizontal de stress.

Para Klein (1995), a controvérsia tem marcado o estudo sobre a origem e evolução das bacias intracratônicas. Segundo este autor, foram propostos na literatura cerca de onze modelos diferentes envolvendo a origem dessas bacias. Os mesmos incluem: (1) incremento na densidade da crosta por mudança de fase para eclogito (Bacia de Michigan), (2) riftiamento associado com a colocação de uma pluma termal na base da litosfera (Bacia de lllinois), (3) metamorfismo termal da crosta inferior para condições limite de fácies anfibolito e xisto verde (bacias intracratônicas australianas), (4) subsidência mecânica causada pelo excesso, não compensado, de massas associadas à intrusões ígneas (Bacia de Williston), (5) reativação tectônica ao longo de estruturas antigas (bacias intracratônicas brasileiras), (6) subsidência termal (Bacia de Illinois), (7) fusão parcial na crosta inferior e drenagem da fusão ígnea resultante para cadeias meso-oceânicas por vulcanismo, resultando na subsidência da bacia acima da zona a partir da qual a fusão ígnea foi removida, (8) variações no stress intraplaca, assumindo uma placa visco-elástica (bacias intracratônicas australianas), (9) subsidência termal após intrusão de granitos anorogênicos em resposta a variação do fluxo de calor durante a quebra dos supercontinentes (aplicáveis a todas as bacias intracratônicas; segundo Klein \& Hsui, 1987), (10) subsidência termal em conseqüência de uma subsidência causada pelo excesso de massa, não compensado isostaticamente, gerado pelo resfriamento de intrusões ígneas (Bacia de Illinois) e (11) subsidência causada em função de eventos tectônicos atuantes na margem da placa (Leighton \& Kolata, 1990). 
O levantamento realizado por Klein (1995) demonstra que os diversos modelos propostos são fortemente influenciados pelas características das bacias, havendo uma certa especificidade em cada um. No entanto, dois aspectos mais gerais estão presentes, a existência de algum tipo de subsidência térmica e a presença de stress intraplaca.

O modelo de subsidência térmica tem sido criticado pelo fato de ser pouco provável que um único decaimento térmico seria suficiente para promover a subsidência de uma bacia intracratônica, que tem lugar ao longo de milhões de anos, por vezes pontuados por momentos de aceleração ou diminuição na taxa de subsidência (Leighton \& Kolata, 1990). Por outro lado, a caracterização de modelos demonstrando que o campo de stress induzido, em contatos convergentes de placa, pode se propagar por toda a placa, afetando as margens passivas e bacias intracratônicas (Cloetingh, 1988), leva a considerar o stress intraplaca como um elemento importante no desenvolvimento desse tipo de bacia. Segundo Ziegler (1988; In Leighton \& Kolata, 1990) o impacto do stress intraplaca pode ser sentido a distâncias maiores que $1300 \mathrm{~km}$.

Leighton \& Kolata (1990), com base na análise dos diferentes modelos existentes para a gênese e evolução das bacias intracratônicas, acreditam que os modelos que levam em conta, as tensões intraplaca e as heterogeneidades da crosta acoplada com a carga sedimentar (e a sobrecarga tectônica para as bacias pericratônicas), parecem oferecer a melhor explicação para a evolução das bacias cratônicas. 


\section{2 - As possíveis causas para a origem da Bacia do Paraná}

\subsection{1 - Introdução}

A Bacia do Paraná, na concepção de Zalán et al. (1990), é uma extensa bacia intracratônica desenvolvida sobre uma crosta continental e preenchida por um conjunto de rochas sedimentares e vulcânicas (espessura máxima em torno de 6000 metros), formadas entre o Ordoviciano e o Cretáceo.

Com relação à caracterização dos mecanismos responsáveis pela origem e evolução da Bacia do Paraná, de forma semelhante ao verificado para as várias bacias intracratônicas descritas na literatura, não existe um consenso entre os diversos pesquisadores que se dedicaram ao tema. Contudo, no conjunto das várias teorias existe um elemento aparentemente unificador, relacionado ao controle exercido pelos elementos tectônicos-estruturais (arcos, altos, lineamentos, zonas de falha), tanto na implantação da bacia como em sua evolução sedimentar, os quais guardam uma relação direta com as estruturas pretéritas do embasamento (Northfleet et al., 1969; Fúlfaro et al., 1982; Brito Neves et al., 1984; Zalán et al., 1987; Zalán et al., 1990).

\subsection{2 - O embasamento da Bacia do Paraná}

A estruturação do embasamento da Bacia do Paraná emerge como um segundo consenso entre os pesquisadores. Vários pesquisadores têm postulado um embasamento composto por uma assembléia de núcleos cratônicos e faixas móveis (Cordani et al., 1984; Zalán et al., 1990) (Fig. 53), definindo um mosaico de blocos (Quintas, 1995).

Milani (1997) introduziu uma nova questão, em relação à caracterização do embasamento da bacia, ao questionar a existência do núcleo 

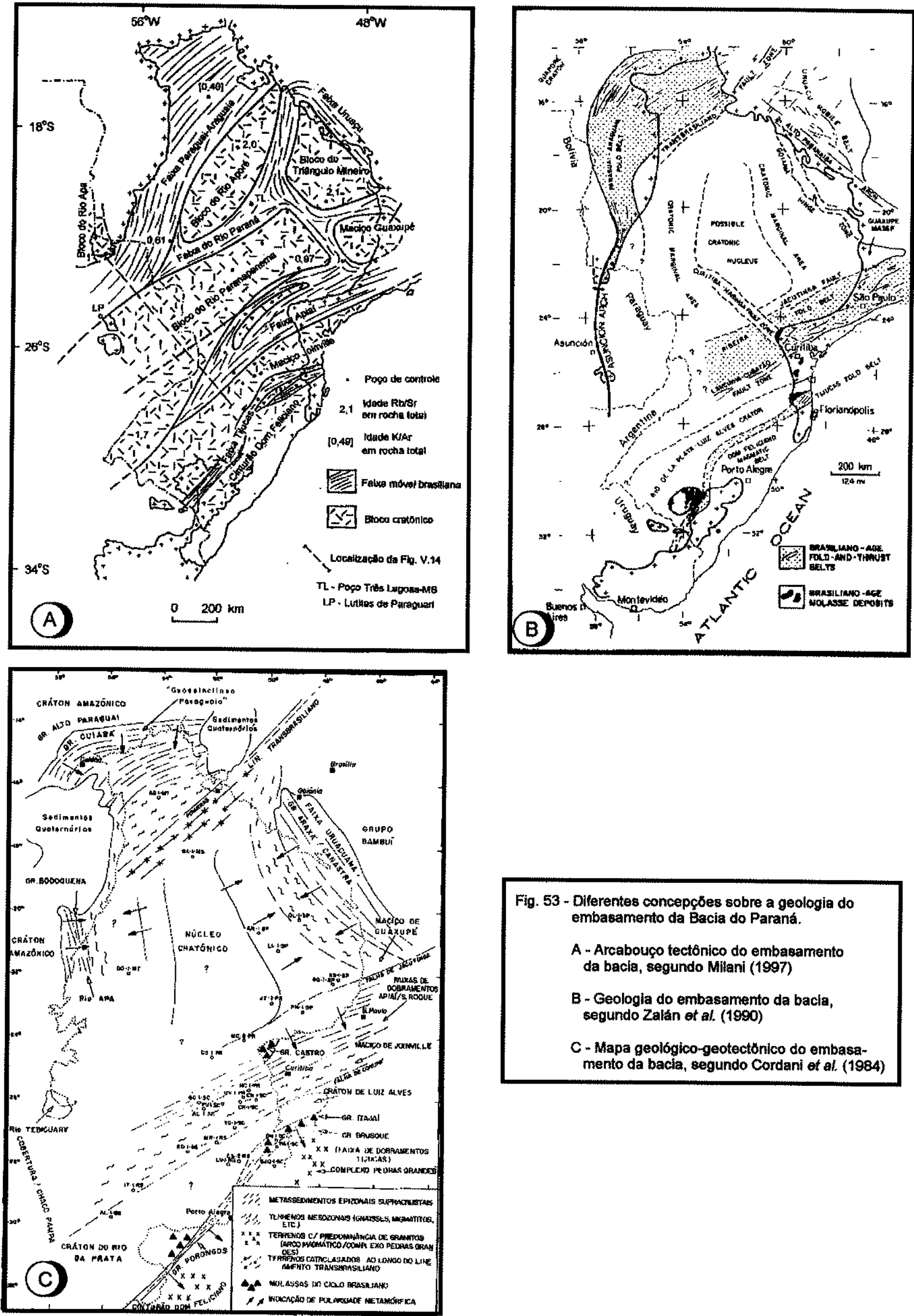

Fig. 53 - Diferentes concepçøes sobre a geologia do embasamento da Bacia do Paraná.

\section{A - Arcabouço tectónico do embasamento} da bacia, segundo Milani (1997)

B - Geologia do embasamento da bacia, segundo Zalán ot al. (1990)

C - Mapa geológico-geotectónico do embasamento da bacia, segundo Cordani ot al. (1984) 
cratônico central, proposto por Cordani et al. (1984) e delimitado, em termos gravimétricos, por Quintas (1995). A existência de um bloco cratônico no centro da bacia foi proposta por Cordani et al. (1984), com base na distribuição das estruturas expostas, nas datações $\mathrm{K}$-Ar de amostras do embasamento, obtidas a partir de furo de sondagens e, também, como salienta Brito Neves et al. (1984), com base na polaridade metamórfica sugerida pelo pelos cinturões brasilianos circunvizinhos. Quintas (1995) realizou a caracterização geofísica do embasamento da bacia, delimitando-o em três grandes zonas, definidas em função do padrão da assinatura gravimétrica. A autora associou estas zonas: a faixa Paraguai - Arco magmático de Goiás (região oeste), ao Maciço de Goiás Bloco Paranapanema (região central) e ao Cinturão Ribeira (região leste). O bloco Paranapanema, segundo a autora, teria características mecânicas semelhantes àquelas do Maciço de Goiás, estando posicionado na parte central da bacia, junto à calha do rio Paraná.

Milani (1997) contesta o modelo de um cráton central, como proposto por Cordani et al. (1984). O autor entende que seria incompativel a existência de um "rifte central", como definido por Marques et al. (1993; In Milani, 1997), na região do suposto núcleo, no qual estariam preservadas grandes espessuras de sedimentos de sua Superseqüência Rio Ivaí. Para Milani (op. cit.), uma área cratônica é caracterizada por grande estabilidade, sendo pouco favorável que sobre ela se desenvolva subsidência e empilhamento sedimentar. Visando compatibilizar esta discrepância, o citado autor introduziu um novo elemento geotectônico denominado faixa móvel do Rio Paraná, que justapõe dois outros domínios geotectônicos denominados bloco Rio Aporé e bloco do Rio Paranapanema, este último com distribuição similar ao bloco Paranapanema de Quintas (1995).

A proposta apresentada por Milani (1997) reforça a idéia defendida por vários autores de que o embasamento da bacia é composto por um mosaico de blocos e megablocos, envolvendo crátons e faixa móveis e, de certa forma, a 
mesma preserva a proposta de existência de areas mais estáveis na parte central da bacia, sobretudo em sua porção centro-leste. A hipótese de áreas cratônicas na parte central da bacia é também aceita por Rocha (1998), a partir de estudos gravimétricos, magnéticos e de fluxo de calor, realizados pela autora, na região entre os paralelos $17^{\circ} \mathrm{S}$ e $33^{\circ} \mathrm{S}$.

O arranjo do embasamento, descrito pelos diversos autores, pode explicar o arcabouço estrutural da bacia, que é dominado por elementos tectônicos lineares agrupados em três distintas direções (NW/SE, NE/SW e W-E), representando falhas ou zonas de falhas, que se interceptam uns aos outros, reproduzindo o arcabouço de blocos e megablocos do embasamento da bacia.

\subsection{3 - Arcabouço Tectônico - Estrutural}

O arcabouço estrutural da bacia foi sumariado por Zalán et al. (1990) (Fig. 54). Na definição desses autores os elementos de direção NW-SW são caracterizados por zonas retilíneas com concentração de falhas e diques, formando extensas zonas de falhas. A origem dessas estruturas ainda não está clara. Contudo, para os autores citados, existem evidências indicando que estes lineamentos são, no mínimo, mais antigos que os lineamentos de direção NE-SW de idade Brasiliana. Esta cronologia foi também admitida por Northfleet et al. (1969) ao descreverem que as estruturas de tendência NE, deslocam as estruturas NW.

A identificação das direções estruturais NW-SE no embasamento da bacia é um outro ponto controverso. Essas estruturas, predominantes na região do Arco de Ponta Grossa, ocorrem secionando transversalmente a faixa móvel Ribeira, de direção NE-SW, que conjuga as rochas do embasamento nesta região. As mesmas são importantes condutores para o evento magmático do Cretáceo. 

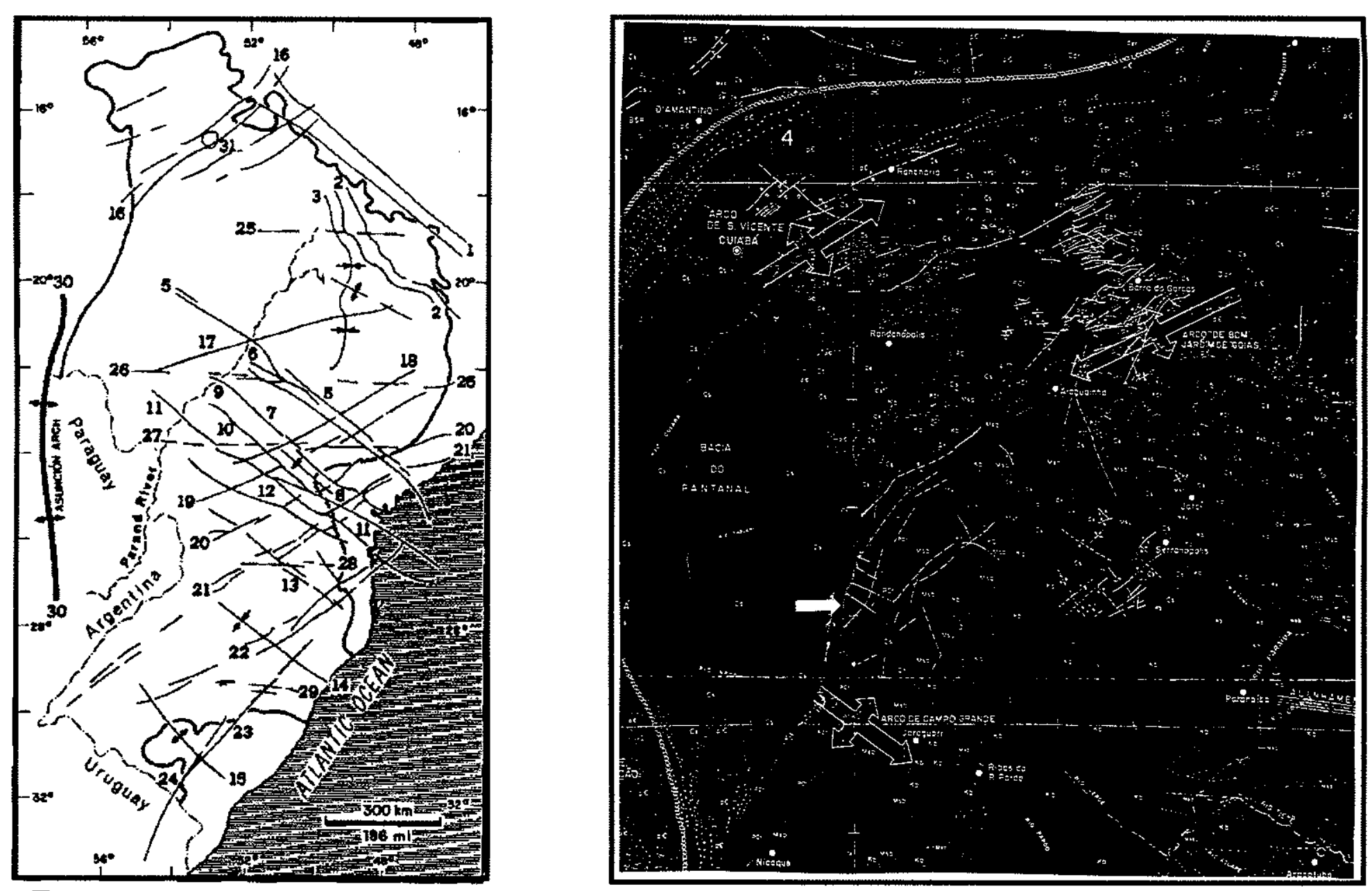

(A)

Fig. 54 - Elemertos estruturais da Bacia do Paraná.

A - Mapa do arcabouço estrutural da Bacia do Paraná, destacando os elemerkos estruturais discutidos nesta pesquisa (extraldo de Zalan er ar., 1090$)$

1) Arco de Alto Paranalba, 5) Zona de falha de Guapiara, 7) Falha de Săo Jeronimo Curiuva, 8) Arco de Ponta Grossa, 9) Zona de Faiha Curitiba - Maringá, 10) Falha do Rio Alonzo, 12) Fatha do Rio Piquiri, 16) Zona de Falha Transbrasitiana, 30) Arco de Assungato 31) Domo de Araguainha

B- Detathe da Zona de Falha Transbrasiliana, destacando os granitos da regia de Coxim (MS). (Fonte: Mapa Geológico - Estrutural Anexo) 
Esses fatos levaram alguns autores a admitir que estas estruturas so toram ativas no Mesozóico. Por outro lado, desde os trabalhos pioneiros realizados na bacia, essas estruturas vêm sendo consideradas como importantes elementos na evolução sedimentar da mesma, sendo responsável pela delimitação dos vários depocentros ao longo de sua evolução (Northfleet et al., 1969; Ramos, 1970; Fúlfaro et al., 1982; Zalán et al. 1990; Eyles \& Eyles, 1993; Eyles et al. 1993).

Entre as estruturas de direção NW-SE, O Alinhamento Guapiara destaca-se como sendo um dos principais elemento controlador da sedimentação da bacia. Para Ferreira et al. (1981), o Alinhamento Guapiara, bem definido na região do Arco de Ponta Grossa, onde se posiciona como o limite setentrional do mesmo, poderia ser estendido ao longo da bacia. Para os autores, o sistema de falhas noroeste, assinalado na folha Corumbá (Corrêa et al., 1979), entre Rio Verde de Mato Grosso e Coxim, que afeta as rochas devonianas, estaria relacionado com o prolongamento deste Alinhamento. Para Ferreira et al. (1981), - Alinhamento de Guapiara atuaria como uma feição positiva separando, no tempo Devoniano, os depocentros Alto Garças e Apucarana. Para Ferreira (1982), a depressão Apucarana seria tectonicamente controlada pela atividade negativa do bloco limitado pelos alinhamentos São Jerônimo - Curiúva e do Rio Alonso.

Aparentemente, o controle deposicional exercido pelos alinhamentos de direção NW-SW, esteve presente ao longo de toda a história evolutiva da bacia. A análise das figuras 44 e 45 que apresentam, respectivamente, a distribuição dos sedimentos das seqüências ordoviciana e siluriana, permite notar uma compartimentação dos depocentros em dois conjuntos: um a sul, onde ocorrem as maiores espessuras sedimentares e um a norte, onde há uma diminuição das mesmas, limitados em uma zona que coincide com a posição do Alinhamento Guapiara, a qual delimita a norte uma zona de "plataforma" mais estável. Rocha (1998) identificou um lineamento magnético, com direção NW-SE, paralelo ao Alinhamento Guapiara, caracterizado por definir uma superfície de deslocamento entre dois segmentos de um bloco cratônico, delimitado por esta 
do rio Paraná. Segundo o relatorio do NEXPAR (1996; apud Rocha, 1998) este lineamento corresponde a linha de charneira da Plataforma Nordeste da Bacia do Paraná. Para Zálan (1998; apud Rocha, 1998) esta linha de charneira evidencia uma falha antiga no embasamento da bacia. Nessa perspectiva, esta linha de charneira pode ter um importante controle na preservação do registro sedimentar pré-devoniano.

Embora as evidências sustentem uma atuação importante desses alinhamentos na história da bacia (vide Eyles \& Eyles, 1993), ainda permanece em aberto a sua gênese. Recentes trabalhos de análise tectono-estrutural realizados em segmentos da Faixa Móvel Ribeira, têm demonstrado a existência de estruturas noroeste em rochas do domínio dessa faixa brasiliana. Heilbron et al. (2000) sugerem que a direção NW pode estar relacionada ao braço de um possivel sistema rift interrompido, associado a uma pluma mantélica, na região de Florianópolis, em posição de costa-afora (offshore) ao cráton Luís Alves. Schmitt et al. (1999), reconhecem na parte sudeste da faixa Ribeira, Bloco Cabo Frio, uma orogenia de idade Cambro-Ordoviciana, envolvendo dois pulsos principais: (1) Cambriano, entre 530 e $514 \mathrm{Ma}$, marcada por metamorfismo de grau alto e deformação NW-SE de baixo ângulo, com transporte tectônico para NW e (2) Ordoviciano, entre 505 e $490 \mathrm{Ma}$, marcada por metamorfismo de fácies anfibolito e estiramento NE-SW, com transporte tectônico para ENE. Esses trabalhos abrem perspectivas para que sejam encontradas a origem dos lineamentos noroeste, tão evidentes na Bacia do Paraná.

Segundo Zalán et al. (1990) os elementos lineares com direção NESE são derivados a partir dos cinturões móveis que se estendem por baixo da bacia, na parte oriental (Cinturões Ribeira e Dom Feliciano) e na parte norteocidental (Cinturão Paraguai-Araguaia) e, também, a partir da Zona de Falha Transbrasiliana, uma estrutura de idade Brasiliana, reativada ao longo da evolução da bacia. 
Dentre as várias estruturas nordeste, o Lıneamento Transbrasiliano é o elemento estrutural mais importante. O Lineamento Transbrasiliano foi definido por Schobbenhaus Filho (1975) como uma faixa intensamente falhada do território brasileiro, representando um elemento estrutural de $1^{\circ}$ ordem, com mais de 2700 $\mathrm{Km}$ de extensão, iniciando no norte do Ceará (Lineamento Sobral - Pedro II) cortando a Bäcia do Parnaíba, o estado de Goiás, e terminando na porção noroeste da Bacia do Paraná, no extremo sudoeste de Mato Grosso. Segundo o autor, os falhamentos relacionados a esse lineamento foram estabelecidos, provavelmente, no Pré-Cambriano.

Na Bacia do Paraná, este lineamento envolve o Sistema de falha do centro-leste de Mato Grosso, definido por Northfleet et al. (1969), como uma zona intensamente falhada no sudoeste / sudeste de Mato Grosso, caracterizada por falhamentos normais, extremamente alongados, podendo atingir até $160 \mathrm{~km}$ de extensão (Falha de Poxoréu). Este lineamento delimita, de forma quase retilínea, a borda noroeste da bacia.

A importância do Lineamento Transbrasiliano no controle da evolução sedimentar da Bacia do Paraná é um aspecto só recentemente analisado. São claras as evidências de que reativações durante o Cretáceo tiveram lugar ao longo desta estrutura, o mesmo não ocorre para os sedimentos mais antigos. O levantamento de campo realizado nesta pesquisa possibilitou demonstrar que durante 0 Carbonífero terminal ocorrem reativações de caráter transtensional ao longo desse lineamento, na região do sudeste de Mato Grosso, controlando a sedimentação inicial da Formação Aquidauana. Nesta região ocorrem dois trends de falhas normais, afetando exclusivamente sedimentos da Formação Ponta Grossa, que controlam a sedimentação carbonifera através da geração de rombográbens. Estes últimos elementos são formados em resposta a um stress horizontal de direção $\mathrm{N} 60^{\circ} \mathrm{W}$, aplicado sobre a zona de deflexão do Lineamento Transbrasiliano (Lopes-Coelho \& Pereira, 2000). Este controle é também observado na borda noroeste da bacia, na região falhada de Correntes, 
pruximo a Sonora (MS). Aparentemente, o mesmo se esiende também até regiões mais ao sul, próximo a Aquidauana (MS). O controle estrutural dos sedimentos da Formação Aquidauana também foi admitido por Eyles et al. (1995, fig. 10), a partir da análise de afloramentos próximo a Rondonópolis (MT). Milani (1997) posiciona o depocentro do pacote Carbonífero ao longo do Lineamento Transbrasiliano, sugerindo um novo espasmo de reativação das estruturas NE-SW.

Como visto, o arcabouço tectônico - estrutural da bacia exerceu um forte controle na história evolutiva da mesma, sendo então necessário buscar nesses elementos as pistas para o entendimento da origem da Bacia do Paraná.

\subsection{4 - A origem da Bacia do Paraná}

Alguns modelos têm sido propostos para explicar a origem da Bacia do Paraná, em quase todos se tenta estabelecer uma relação entre a gênese da bacia e a reativação de estruturas herdadas do embasamento, por vezes associando-se a este modelo um estágio de subsidência térmica.

Segundo Fúlfaro et al. (1982) a direção da calha deposicional da seqüência devoniana foi francamente governada por uma direção NW-SE transversal à direção do seu embasamento. Em função dessas características os autores admitiram que a sedimentação mais basal da bacia estaria fortemente controlada por aulacógenos tardios herdados do Eopaleozóico, de direção NW$\mathrm{SE}$, formados ao final da cratonização da faixa de dobramentos da região sul e sudeste. Ainda segundo os autores, o levantamento da faixa dobrada sul/sudeste e o desenvolvimento dos aulacógenos fariam com que o assoalho da bacia inclinase para oeste, em direção a uma faixa ativa na região andina, possibilitando a formação de uma bacia marginal siluriana. Essa proposta define a subsidência mecânica como condutora do processo inicial de formação da bacia. 
Por sua vez, Cordani et al. (1984) advogam uma subsidência térmica como controladora da origem da bacia, ao admitirem que a Bacia do Paraná, e também a Bacia do Maranhão (Parnaíba), poderiam ter se iniciado como produto da contração da litosfera, após a expansão térmica devido à orogênese brasiliana, caracterizada por alto gradiente termal (Brito Neves et al., 1984). Esses autores também admitém que a subsidência teria sido precedida pelo aparecimento de grandes rifts (e/ou aulacógenos), preenchidos por seqüências vulcanosedimentares do Cambro-Ordoviciano, em muitos casos interpretadas como "molassas" do próprio ciclo brasiliano. Na visão de Brito Neves et al. (1984), essas molassas apresentam um significado tectônico adicional por preencherem os rifts precursores da subsidência das bacias cratônicas do Paraná e Maranhão.

Segundo Zalán et al. (1990) não existem evidências da presença de um rift central precursor, cujo o estiramento crustal e a anomalia térmica relacionada precedessem a fase subseqüente de subsidência térmica. Assim, os autores não concordam com a proposta de Cordani et al. (1984), que admitiram as molassas cambro-ordocivianas do Ciclo Brasiliano como remanescentes destes rifts precursores. No entanto, Zalán et al. (1990) não afastam a possibilidade da existência de um período inicial de estiramento crustal como condutor da subsidência da Bacia do Paraná, em função da distribuição linear do depocentro da Formação Rio Ivaí, composta, na visão desses autores por sedimentos do NeoOrdoviciano / Eo-Siluriano. Porém, os autores citados admitem que o resfriamento pós-orogenia brasiliana pode ter induzido uma subsidência termal de caráter regional, e o mesmo poderia se configurar como o mecanismo condutor para a depressão inicial da bacia. $\mathrm{Na}$ visão dos autores, a história do resfriamento adicionada à sobrecarga sedimentar das seqüências siluriana e devoniana pode justificar a primeira importante fase de subsidência da bacia.

A hipótese de implantação da Bacia do Paraná apresentada por Milani (1997) e Milani \& Ramos (1998) defende um caráter essencialmente mecânico para a subsidência inicial da mesma. Milani \& Ramos (1998) acreditam 
que a acomodação dos esforços da Orogenia Ocloyica na região cratônica induziu a subsidência inicial da bacia, na forma de depocentros transtensivos alongados na direção SW-NE. Para Milani (1997), a área de ocorrência do pacote sedimentar mais antigo da bacia reflete uma subsidência controlada por lineamentos do embasamento. Ainda segundo Milani (1997) "o campo de esforços regional compressivo dóminante neste intervalo de tempo (Neo-Ordoviciano) e a geometria em calhas da Formação Alto Garças, alongadas segundo a orientação dos lineamentos correspondentes a descontinuidades estruturais do substrato, compõem uma associação de informações que sugere ter esta unidade basal da Bacia do Paraná sido acumulada num contexto intraplaca de subsidência por reativação transtensiva de suturas do embasamento, com o desenvolvimento de grábens que controlaram a localização dos depocentros de seu pacote mais antigo, o da Formação Alto Garças". Para Milani \& Ramos (1998) a associação da sedimentação inicial com magmatismo intraplaca sugere fortemente ter ocorrido uma reativação ordoviciana de suturas antigas do embasamento.

Ainda no entender de Milani (1997), a subsidência da bacia foi controlada pela propagação continente-adentro da flexura litosférica originada por sobrecarga tectônica junto à margem convergente do Gondwana sul-ocidental e, também pela reativação transtensiva de lineamentos SW-NE da trama do embasamento. Uma subsidência eminentemente intracratônica desvinculada de qualquer mecanismo ou campo de tensões relacionada à borda de placas, só ocorreu na bacia, segundo este autor, devido à carga dos basaltos Serra Geral.

As teorias apresentadas para a identificar os mecanismos formadores da Bacia do Paraná, em sua grande maioria, têm por base a análise da distribuição regional apresentada pelos sedimentos basais da bacia. A caracterização desses sedimentos, tanto em afloramentos como em subsuperfície, é bastante controversa como foi demonstrado por Moreira \& Borghi (1999b). Nesta pesquisa, seguindo-se a linha de atuação desenvolvida por Pereira (1992), procuramos separar os sedimentos arenosos ordovicianos, daqueles associados à 
Formação Vila Maria, de idade provavelmente Siluriana. Este proceaimento produz como resultado um mapa de isópaca para seqüência ordoviciana (Fig. 44), o primeiro evento deposicional da bacia, que difere daqueles precedentes que tentaram caracterizar a distribuição desses sedimentos basais. O mapa proposto por Zalán et al. (1990), referente a sua Seqüência Siluriana, envolve os sedimentos das formações Rio Ivaí, Vila Maria e Furnas, possuindo um range sedimentar bem mais amplo do que o considerado em nosso mapa. A proposta paleogeográfica apresentada por França et al. (1995), propõe uma distribuição dos sedimentos ordovicianos fortemente controlados por calhas de direção NE-SW. Como salienta Moreira \& Borghi (1999b), a mesma parece ser um forma elegante de representar a ocorrência dessa rochas, embora ainda muito conceitual. Ao longo da pesquisa não foram encontradas evidências da presença de sedimentos conglomeráticos ordovicianos no extremo nordeste da bacia, como também não se observa relato da ocorrência da Formação Piranhas no extremo norte da bacia, estando a mesma descrita na área de influência do Arco de Bom Jardim de Goiás. A distribuição que estamos propondo nesta pesquisa também difere daquela apresentada por Milani (1997), em função das distintas interpretações dadas aos, sedimentos pré-devonianos, nos poços 2-RI-1-PR, 2-AR-1-SP e 2-TL-1-MT, e também pelo registro de uma ampla faixa de ocorrência de sedimentos "ordovicianos", correlacionáveis à Formação Alto Garças, na borda noroeste da bacia.

O mapa de isópaca da Seqüência Ordoviciana, descrito nesta pesquisa (Fig. 44), demonstra a existência de dois eixos principais de deposição: um mais proeminente, posicionado na parte centro-oeste da bacia, com direção aproximada NNE-SSW, e um segundo, mais ao sul, com direção NW-SE. A distribuição dos sedimentos ao longo desse eixo principal, aproximadamente N-S, apresenta um notável paralelismo com a anomalia gravimétrica negativa mapeada por Vidotti et al. (1998), na borda oeste da bacia (Fig. 55). 

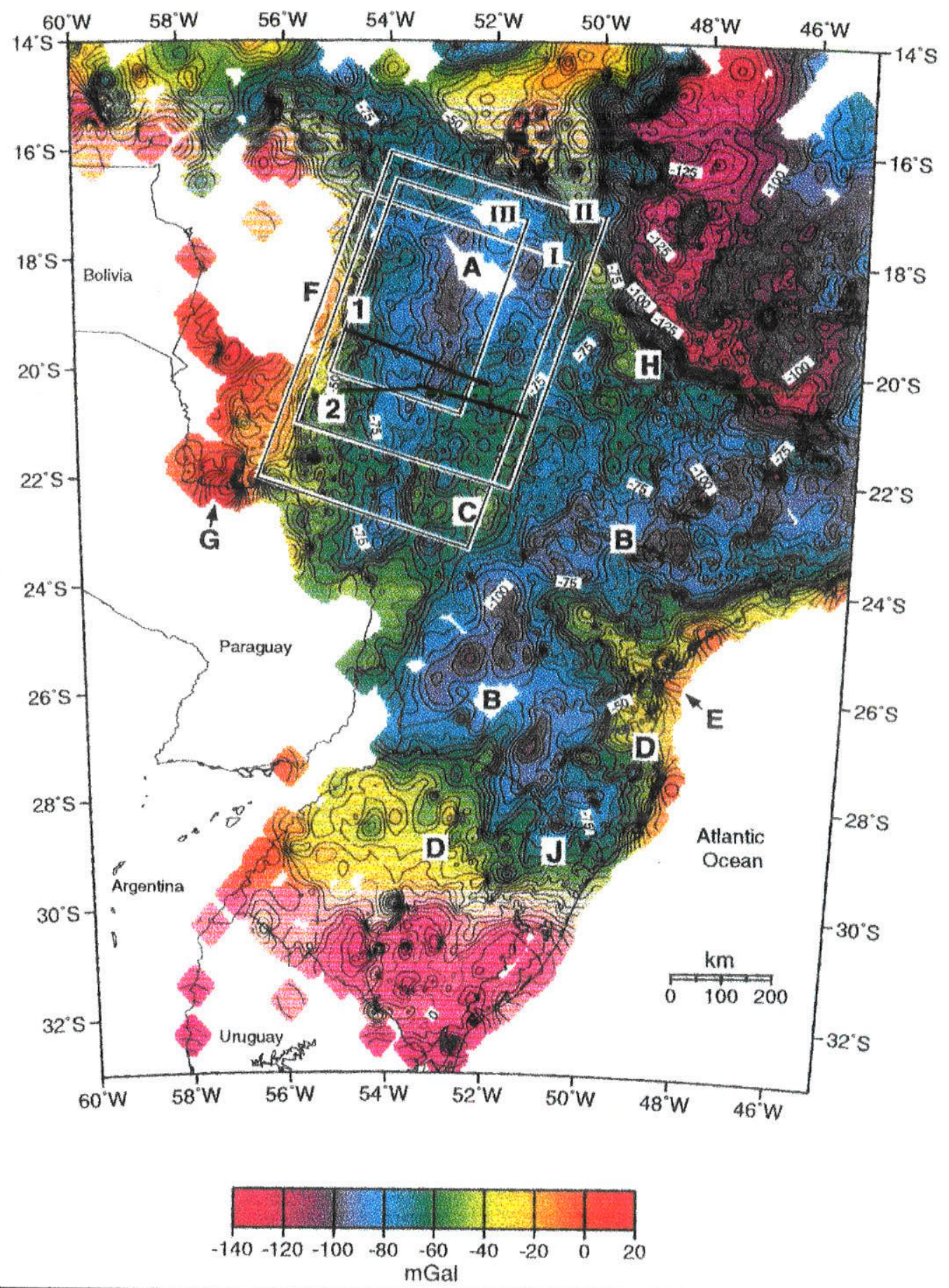

Fig. 55 - Mapa gravimétrico de Bouguer da Bacia do Paraná, extraído de Vidotti et al. (1998). Dados gravimétricos de Bouguer interpolados, com grade de contorno $(5 \times 5 \mathrm{Km})$ e intervalo de contorno de 5 mgal, a partir dos projetos: Gravimetria da America do Sul e Gravimetria Anglo - Brasileira, que recobrem a Bacia do Paraná e áreas adjacentes.

A) baixo gravimétrico ocidental; B) baixo gravimétrico oriental; C) alto gravimétrico relativo; D) cráton de Luís Alves: E) Arco de Ponta Grossa; F) gradientes escalonados na borda ocidental da bacia; G) arco de Assunção; H) zona de chaneira de Goiânia; J) cinturão magmático Dom Feliciano 1. II e III, áreas onde foram estimadas as profundidades do embasamento área I $=4+/-0,5 \mathrm{Km}$, área II = 5,2+l- 0,5 Km e área III = 7,4 +l-2 Km.1 e 2) localização dos perfis de modelagem gravimétrica. 
O mapa de Vidotti et al. (1998) pode ser dividido, grosseiramente, em três conjuntos: baixos gravimétricos oriental $(A)$ e ocidental $(B)$, separados por um relativo alto gravimétrico $(C)$. O baixo gravimétrico oriental $(B)$, com direção nordeste, é paralelo à Faixa Móvel Ribeira composta geralmente por rochas metamórficas de baixa densidade, rochas sedimentares e vulcânicas intermediárias a ácidas. $O$ baixo gravimétrico ocidental (A) apresenta um "surpreendente" arranjo gravimétrico alongado com direção N-S, ao longo de toda borda oeste da bacia. Segundo os autores, a explicação mais convincente para esta anomalia é a identificação de um sistema rift, proterozóico ou eo-paleozóico, de direção N-S, implantado sob as seqüências sedimentares da bacia. O mesmo teria $600 \mathrm{~km}$ de comprimento e aproximadamente entre 100 e $50 \mathrm{~km}$ de largura, com um fator de extensão litosférica $<1.3$, sendo segmentado em três possíveis bacias, relativamente deslocadas: S3 $\left(18^{\circ} \mathrm{S} / 19^{\circ} \mathrm{S}\right.$ e $\left.53^{\circ} \mathrm{W}\right), \mathrm{S} 2\left(20^{\circ} \mathrm{S}\right.$ e $\left.53^{\circ} \mathrm{W}\right)$ e $\mathrm{S} 1$ $\left(23^{\circ} \mathrm{S}\right.$ e $54^{\circ} \mathrm{W}$ ) (Vidotti et al., op. cit.; fig. 4). Além do paralelismo já observado, ocorre ainda uma forte correlação entre os depocentros, identificados nas áreas próximas aos poços 2-AG-1-MT e 2-DO-1-MT, e os segmentos $\mathrm{S} 3$ e $\mathrm{S} 1$ definidos por estes autores. O perfil assimétrico, em direção a leste, observado no rift proposto por Vidotti et al. (1998), como também o escalonamento gravimétrico, demonstrando valores relativamente mais altos em direção a borda oeste da bacia, correlaciona-se muito bem com a distribuição da Formação Alto Garças, na seção Chapada dos Guimarães (MT) - Poço 2-LA-1-SP (Fig. 33). Da mesma forma, esta estrutura explicaria o rápido espessamento da seção ordoviciana entre a região de Rio Negro (MS) e o poço 2-DO-1-MT, confirmando a hipótese de Soares (1991) da existência de blocos abatidos, formando grábens, nesta área. $O$ rift proposto pelos autores tem sua porção ocidental limitada pelo Cinturão Móvel Paraguai-Araguaia, podendo então o mesmo estar posicionado, caso esta faixa se estenda por baixo da bacia, como advogado por Quintas (1995), no interior do cinturão brasiliano.

A notável correlação observada entre a distribuição dos sedimentos ordovicianos e o rift diagnosticado na porção oriental da bacia, nos leva a acreditar 
que a sedimentação inicial da mesma teria ocorrido ao longo desta calha. Devemos considerar também que a estrutura mapeada encontra-se no domínio do Lineamento Transbrasiliano (Fig. 54) podendo a mesma, em nossa opinião, representar a assinatura deste lineamento em subsuperfície. Assim a origem da bacia guardaria uma direta relação com a história desse lineamento.

O Lineamento Transbrasiliano, com diagnosticado por Brito Neves et al. (1984), controla os principais depocentros da Bacia do Parnaíba. Segundo estes autores, durante as atividades tectônicas finais do ciclo Brasiliano, no Cambro-Ordoviciano, o Lineamento Transbrasiliano (Falha de Sobral) e falhas associadas (Falha de Jaguapari) criaram uma zona de rifts intracratônicos. Como discutido pelos autores, há uma clara evidência do espessamento da seqüência paleozóica ao longo do trend Transbrasiliano. O controle sedimentar exercido por esse lineamento sobre os sedimentos mais antigos dessa bacia é, também, demonstrado através dos mapas de isópacas para o Grupo Serra Grande (Neoordoviciano / Siluriano) propostos por Cunha (1986) e Góes et al. (1989). Baldis et al. (1991), também identificaram a importância regional desse lineamento no controle da sedimentação eo-paleozóica, associando-o a uma megaestrutura, de caráter transgondwânico, responsável pela geração de bacias tipo "pull-apart" no Eo-Cambriano. Em uma posição intermediária à bacias do Paraná e do Parnaiba, são registrados extensos falhamentos, com até $150 \mathrm{Km}$ de extensão, limitando o Gráben de Água Bonita, onde estão enfossados os sedimentos arenosos da Formação Água Bonita (Baptista \& Cartner-Dyer, 1966); posicionados estratigraficamente por Drago et al. (1981) abaixo dos sedimentos devonianos da Bacia do Paraná.

Como foi possivel demonstrar, o Lineamento Transbrasiliano, no extremo nordeste da bacia, apresenta um comportamento transtensivo, controlando a sedimentação inicial da Formação Aquidauana. Como salienta Zalán et al. (1990), as zonas de falhas de direção noroeste, observadas na bacia, são preferencialmente reativadas por movimentos transcorrentes. 
Outro aspecto interessante referente a este lineamento é a presença, em sua zona de atuação, de corpos graníticos de idade Cambro-Ordoviciana. No limite noroeste da bacia, nas regiões próximas a Coxim (MS) e Rio Verde de Mato Grosso (MS), entre $18^{\circ}$ e $19^{\circ}$ de latitude sul, ocorrem um série de manifestações ígneas (granitos Coxim, Rio Negro e Taboco) com idades em torno de $490 \mathrm{Ma}$ (Del'arco et al., 1982) correlacionáveis ao Granito São Vicente. O granito São Vicente foi descrito por Almeida \& Mantovani (1975), sendo tectonicamente classificado como uma intrusão "pós-cinemática", intrudida à pequena profundidade, posicionada no limite Cambro-Ordoviciano, secionando brusca e nitidamente as estruturas das rochas encaixantes. Estas são compostas por rochas metamórficas do Grupo Cuiabá, que já se encontravam metamorfizadas e deformadas por eventos finais que tiveram lugar na faixa de dobramentos Paraguai-Araguaia, quando da intrusão. Barros et al. (1982), recalcularam as razões isotópicas obtidas por Almeida \& Mantovani (1975) e chegaram a uma idade de $500+/-4 \mathrm{Ma}$, correspondente ao emplacement deste maciço granítico. $\mathrm{Na}$ borda nordeste da bacia, no domínio do lineamento, ao sul da cidade Piranhas (GO), ocorre a suite intrusiva Serra Negra, a qual no entender de Almeida \& Mantovani (1975), ocorreu simultaneamente ao Granito São Vicente.

A partir desse conjunto de evidências há uma necessidade de se buscar um modelo de gênese da bacia que contemple reativações de caráter transtensional, em zonas de fraqueza herdadas do embasamento, associado à intrusões graníticas. Klein \& Hsui (1987) notaram uma sincroneidade no desenvolvimento de bacias intracratônicas localizadas na América do Norte, Europa, África e América do Sul, formadas aproximadamente ao mesmo tempo (entre 550 e $500 \mathrm{Ma}$ ). Esses autores acreditam que essa bacias foram originadas em resposta à quebra de um supercontinente pré-Cambriano tardio. Na hipótese elaborada por esses autores e desenvolvida por Klein (1995), quando da colagem dos blocos continentais no processo de formação de um supercontinente, as menores taxa de dispersão de calor podem transformar o mesmo em uma zona 
quente, levando a um aumento na taxa de fusão parcial da litosfera continental, em resposta a esse fluxo de calor localizado. Como conseqüência pode ocorrer a intrusão, em níveis crustais rasos, de granitos anarogênicos, gerando descontinuidade nas propriedades físicas da crosta continental (Fig. 56). Extensão acompanhada de estiramento podem ocorrer sobre zonas no interior da litosfera, onde os granitös anarogênicos intrudiram. A crosta imediatamente acima da zona particularmente fundida pode ser afinada, favorecendo um estiramento de caráter local ou regional, induzindo um processo de riftiamento. Assim, a intrusão desses granitos pode gerar domeamento, ruptura (riftiamento), e subsequente subsidência mecânica e termal, na crosta acima das intrusōes. O contínuo estiramento poderia fraturar os corpos graníticos, gerando condutos para a ascensão de material mantélico. O resfriamento do material intrudido causaria subseqüente subsidência termal. O modelo proposto por Klein (1995) contempla a formação das bacias intracratônicas após eventos orogénicos colisionais, fato que se amolda a realidade da Bacia do Paraná.

Para Klein (1995), quando o campo de stress atuante na bacia varia de compressional para extensional, ou vice-versa, ou em direção e magnitude, podem ser esperadas significativas rupturas e deformação superficial associada sobre o supercontinente, especialmente na zona crustal heterogênea.

Assim, acreditamos que a seqüência ordoviciana da Bacia do Paraná teve sua deposição controlada pelo Lineamento Transbrasiliano, a partir da geração de um sistema rift, no interior desse lineamento, inicialmente induzido por intrusões graníticas de idade Cambro-Ordoviciana. A propagação dos esforços compressivos gerados na borda da placa, em forma de esforços transtensionais, (no sentido de Milani, 1997) ao longo do lineamento, somada à carga sedimentar e ao resfriamento das massas intrudidas conduziram a subsidência inicial da Bacia do Paraná. 
A.

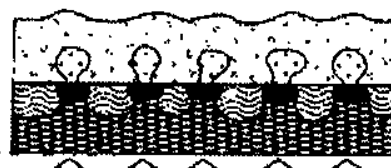

B.

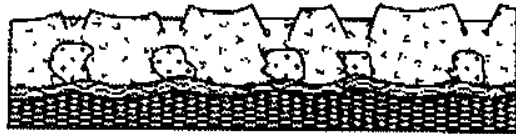

c.

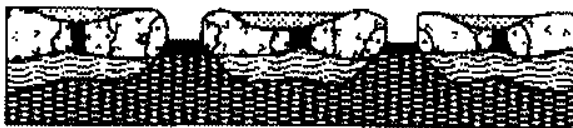

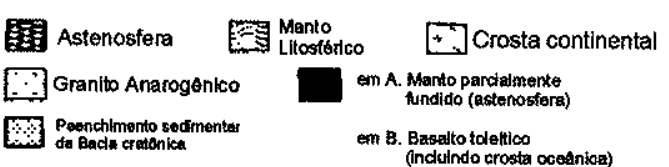

Fig. 56 - Representação esquemática do processo de formação de bacia intracratônica proposto por Klein (1995), modificado de Klein \& Hsui (1987).

A. Evolução e simultânea formação de bacias intracratônicas, a medida que a crosta do supercontinente é parcialmente fundida e o granito anarogênico intrude, durante o estágio no qual o supercontinente está submetido a um alto gradiente térmico.

B. Em seguida, inicia-se o processo de formação do rift, controlado por falhamentos (subsidência mecânica).

C. Esta zona rift, controlada pela subsidência térmica, gera uma bacia intracratônica em forma de plato, a medida que ocorre o resfriamento dos corpos anarogênicos. Consequentemente, as bacias intracratônicas ocorrem sobre corpos graníticos anarogênicos. 


\section{3 - Eventos modificadores atuantes na Bacia do Paraná}

Um aspecto que caracteriza a evolução tectono-sedimentar da Bacia do Paraná é a influência exercida na sua história evolutiva pelas estruturas herdadas de šeu embasamento. Esta influência está presente tanto no controle inicial da sedimentação, onde estas estruturas funcionaram como condutoras da subsidência inicial da bacia (Tectônica Formadora), como controlando a preservação do registro sedimentar (Tectônica Modificadora).

\section{O Lineamento Transbrasiliano e o Alinhamento de Guapiara,} destacam-se como os elementos estruturais que conduziram a história sedimentar da bacia. Se considerarmos a correlação estabelecida por Eyles et al. (1995), entre o Alinhamento de Guapiara e o Lineamento de Chiquitos, o Alinhamento de Guapiara ganharia o significado de um elemento estrutural de primeira ordem, o qual relacionado ao Lineamento Transbrasiliano, geraria um abrangente "par conjugado" intraplaca, limitando blocos cratônicos mais estáveis.

A atuação combinada destes elementos exerceu um papel preponderante na preservação do registro sedimentar, como demonstrado pelos mapas de distribuição dos sedimentos obtidos nesta pesquisa. Admitimos que a origem da bacia está intrinsecamente ligada a movimentos tectônicos no domínio do Lineamento Transbrasiliano, no Ordoviciano. A contínua subsidência e a conseqüente expansão da bacia no Siluriano não ocorreu, aparentemente, de forma homogênea, definindo-se um zona mais profunda ao sul do Alinhamento Guapiara, em contraste com uma zona mais rasa a norte (Fig. 45). No entanto, o controle exercido por esse alinhamento pode ter, também, um caráter modificador, associado a um evento de mobilidade tectônica pré-Furnas, responsável pela expressiva perda de seção registrada na Seqüência Siluriana, materializada no contato discordante entre as formações Furnas e Vila Maria. Este fato é evidenciado no mapa de isópaca, que envolve toda a sedimentação pré-Furnas 
(Fig. 46). Na borda noroeste da bacia, a norte do Alinhamento Guapiara e a sul dos falhamentos da região do rio São Lourenço, inclusos no contexto do domínio norte do Lineamento Transbrasiliano, não ocorre registro da sedimentação siluriana, sendo o embasamento recoberto diretamente por depósitos devonianos. A perda de seções paleozóicas, nesta região, associada ao Alinhamento Guapiara, tambëm foi diagnosticada por Fúlfaro \& Perinotto (1994). Da mesma forma, Faria et al. (1994) identificam, na região do Arco de Ponta Grossa, uma tectônica pré-Furnas ativa, caracterizada pela influência dos lineamentos NW-SE no registro sedimentar da Formação lapó. Aparentemente, ocorre uma reorganização da bacia no tempo "pré-Furnas", impingindo a mesma substancial perdas, no registro das seções ordoviciana e siluriana, condicionadas pelos lineamentos estruturais.

Após esta reativação, materializada pela discordância entre a seqüência siluriana e a seqüência devoniana, tem lugar a sedimentação da porção basal da Formação Furnas em contexto tectônico mais estável, a julgar pela relativa homogeneidade da espessura desse pacote sedimentar, bem como pela distribuição espacial dos sistemas deposicionais. No entanto, são observadas consideráveis variações na espessura da Formação Furnas em direção a borda nordeste, onde não se apresenta a seqüência basal de terceira ordem, descrita na seção 2-RI-1-PR - 2-AR-1-SP, e a superfície transgressiva da Seqüência EoDevoniana posiciona-se a poucos metros do embasamento. Contudo, a distribuição dos sedimentos permite a montagem de um esboço paleogeográfico segundo o qual a Bacia do Paraná, como um todo, parece ter se comportado conforme o modelo de uma bacia em rampa com a paleopendente principal direcionada para WSW (Fig. 48).

A compartimentação observada na bacia prossegue ao longo do Devoniano, culminando no Meso-Devoviano com uma intensa diferenciação entre a parte norte e sul da mesma, controlada segundo Ferreira et al. (1991), pelo Alinhamento Guapiara. Este controle gerou dois depocentros (Northfleet et al., 
1969) formalizados por Ramos (1970), como as sub-bacias de Alto Garças, depocentro norte, e de Apucarana, depocentro sul. Estas duas sub-bacias só voltaram a ter uma comunicação franca no Givetiano / Frasniano (cf., Melo, 1988), associada ao momento de máxima inundação da Seqüência Meso-Neodevoniana.

Posterior a esta sedimentação, a bacia foi palco de um novo rejuvenescimento tectônico, marcado pela movimentação transtensiva ao longo do Lineamento Transbrasiliano, controlando a sedimentação inicial da Formação Aquidauana.

A história que emerge desse conjunto de informações, contempla uma evolução para a Bacia do Paraná, na qual estão presentes dois compartimentos estruturais distintos, posicionados a norte e a sul de uma zona estrutural balizada pelo Alinhamento Guapiara, a qual ao longo dessa evolução teve o comportamento de uma linha de charneira. O compartimento norte, desenvolvido sobre um substrato cratônico mais estável, teve a sua subsidência conduzida por sucessivas reativações transtensivas do Lineamento Brasiliano, somado a sobrecarga sedimentar. Neste domínio, ao longo do tempo há uma preferencial deposição dos sedimentos em condições continentais e de plataforma marinha rasa. Por outro lado, o compartimento sul, estabelecido sobre diferentes faixas de dobramentos de idade brasiliana, parece ter sua subsidência controlada pela propagação continente-adentro (senso Milani, 1997) da flexura litosférica originada por sobrecarga tectônica junto à margem do Gondwana, decorrentes dos diferentes eventos orogênicos, que tiveram lugar na margem proto-Andina da América do Sul, ao longo do Paleozóico (Rapela et al., 1998). Neste segmento preservam-se, no intervalo de tempo analisado, sedimentos associados à deposição em condições de plataforma mais profunda. Este modelo evolutivo respalda a divisão da Bacia do Paraná em duas sub-bacias: Alto Garças e Apucarana, como proposto por Northfleet et al. (1969) e formalizada por Ramos (1970) 
Um aspecto ainda não definitivamente esclarecido relaciona-se ao mecanismo indutor dos movimentos que modificam o registro sedimentar preservado. Os dados apresentados nos levam a acreditar, que excluídas as causas climáticas, esses movimentos são reflexos dos efeitos compressionais que ocorreram na margem Gondwana, como aqueles sumariados em Rapela et al. (1998). Compartilham dessa visão Zalán et al. (1990) e Soares (1991). Por outro lado, Milani (1997) acredita que a atenuação dos efeitos tectônicos na margem do Gondwana, induzindo uma subsidência moderada, associada a uma queda eustática, patrocinaria o desenvolvimento de ampla erosão. Lima \& Lima Neto (1998), analisando o atual efeito compressivo na Placa Sul-americana, em função da convergência entre esta placa e a placa de Nazca, identificaram a existência de uma forte ligação mecânica entre a deformação Andiana e a deformação intraplaca observada. Segundo os autores, a deformação intraplaca é fortemente dependente das estruturas pré-cambrianas mais importantes. Eles também descrevem um levantamento do lado ocidental do cráton brasileiro devido, provavelmente, a um bulge flexural induzido por sobrecarga vertical e horizontal associada com a dinâmica da cadeia. Como conseqüência desse levantamento ocorre denudação das coberturas sedimentares, expondo o núcleo cratónico, e gerando sedimentação. Nesse modelo, o efeito compressivo pode induzir superfícies erosivas de caráter regional no interior cratônico, corroborando o modelo aqui discutido. 


\section{Capitulo 5 -Considerações finais e Conclusões}

\section{1 - Considerações Finas}

A análise da evolução tectono-sedimentar da Bacia do Paraná no intervalo Ordoviciano - Devoniano, com especial ênfase às partes norte e paraguaia da bacia, abordada nesta pesquisa, foi realizada com base na integração de dados sedimentológicos, estratigráficos, bioestratigráficos e geoquímicos, obtidos ao longo de uma ampla faixa de exposição dos sedimentos e a partir de poços e furos de sondagem.

Esta abrangente base de dados possibilitou atingir os objetivos traçados inicialmente, culminando com o estabelecimento de um arcabouço estratigráfico representativo do intervalo de tempo em estudo. Um dos principais pontos da análise realizada foi o estabelecimento, com o apoio de vários especialistas, de um arranjo bioestratigráfico para o range Ordoviciano Devoniano. A informação bioestratigráfica foi fundamental para o empilhamento estratigráfico aqui proposto, sobretudo para definição do mesmo no Paraguai, e também, na certificação do hiato deposicional existente entre os membros inferior e médio da Formação Ponta Grossa.

O arranjo estratigráfico descrito para o Paraguai introduz algumas modificações que podem se revestir de uma aplicação prática. As correlações estratigráficas, com base nos novos dados bioestratigráficos, ampliam substancialmente a espessura do intervalo pelítico Siluriano, bem como o posiciona em situações mais profunda de soterramento. Em que pese os baixos valores de COT, estes resultados podem melhorar as perspectivas de geração deste intervalo. Da mesma forma, a nova proposta de correlação entre os poços Assunção 1 e Assunção 2, introduz a possibilidade da existência de um conjunto sedimentar com mais de 1000 metros de espessura, envolvendo sedimentos do 
Ordoviciano ao Eo-Levoniano, preservado no poço Assunção 2, em profundidades superiores a 2900 metros.

Da mesma forma, a caracterização de corpos arenosos isolados em fácies pelíticas como produto de regressão forçada, posicionados no trato de mar baixo da seqüência meso/ neo-devonina, também pode resultar em uma aplicação prática. Esses corpos são grossos, formados por barras tempestíticas, normalmente limitados acima e abaixo por follhelhos negros, laminados, sendo freqüente a observação de vestígios de óleo nos arenitos, em especial quando ocorre, em relativa proximidade, diques associados ao derrame Serra Geral. A observação de valores COT, relativamente elevados, em folhelhos do EoFrasniano, reforça a idéia de que este horizonte estratigráfico pode se comportar como um possivel intervalo gerador.

Por fim, dentro desta visão de aplicabilidade do estudo, a caracterização de um controle tectônico-estrutural para deposição da Formação Aquidauana, exercido pelo Lineamento Transbrasiliano, pode ter um papel importante em termos exploratórios, uma vez que os arenitos do Grupo Itararé, crono-correlatos a esta unidade, são considerados importantes reservatórios da bacia.

\section{2 - Conclusões}

- Os sedimentos ordovicianos da Bacia do Paraná tiveram sua deposição controlada pelo Lineamento Transbrasiliano a partir da geração de um sistema rift, no interior desse lineamento, inicialmente induzido por intrusões graníticas de idade Cambro-Ordoviciana. A propagação dos esforços compressivos gerados na borda da placa, em forma de esforços transtensionais, ao longo do lineamento (senso Milani, 1997), somada à carga sedimentar e ao 
resfriamento das massas intrudidas conduziram a subsidência inicial da Bacia do Paraná.

- O Lineamento Transbrasiliano e o Alinhamento de Guapiara, destacam-se como os elementos estruturais que conduziram a história sedimentar da bacia, atuando de forma conjugada. Essa atuação combinada exerceu um papel preponderante na preservação do registro sedimentar.

- A Bacia do Paraná, no intervalo de tempo enfocado, teve sua evolução marcada por dois compartimentos estruturais distintos, posicionados a norte e a sul, de uma zona estrutural balizada pelo Alinhamento Guapiara. 0 compartimento norte, desenvolvido sobre um substrato cratônico mais estável, teve a sua subsidência conduzida por sucessivas reativações transtensivas do Lineamento Brasiliano, somado a sobrecarga sedimentar. Por outro lado, o compartimento sul, estabelecido sobre diferentes faixas de dobramentos de idade brasiliana, parece ter sua subsidência controlada pela propagação continenteadentro (senso Milani, 1997) da flexura litosférica originada por sobrecarga tectônica junto à margem do Gondwana. Este modelo evolutivo respalda a divisão da Bacia do Paraná em duas sub-bacias: Alto Garças e Apucarana, como proposto por Northfleet et al. (1969) e formalizada por Ramos (1970)

- O arcabouço estratigráfico, para o intervalo Ordoviciano Devoniano é composto por quatro seqüências deposicionais de segunda ordem (no sentido de Vail et al., 1977b; página 86), consideradas como do Tipo - 1 e estabelecidas com base nos preceitos da Estratigrafia de Seqüência. Foram definidas as seqüências ordoviciana, silurina, eo-devonina e meso/neo-devoniana.

- A Seqüência Ordoviciana é composta pelos sedimentos associados à Formação Alto Garças, no Brasil, e pelo Grupo Caacupé, no Paraguai. A mesma teve sua deposição inicial controlada pelo Lineamento Transbrasiliano. A ausência de informações bioestratigráficas para estes sedimentos não permite definir a 
abrangência do tempo envolvido nesta seqüência.

- A Seqüência Siluriana é formada por sedimentos associados aos intervalos inferior, médio e superior da Formação Vila Maria e pelas rochas do Grupo Itacurubi, no Paraguai. Esta seqüencia envolve todo o intervalo Llandoveriana. A partir do zoneamento bioestratigráfico realizado pôde-se caracterizar uma idade mínima Rhuddaniana para os sedimentos posicionados abaixo da superfície transgressiva; uma idade Aeroniana para esta superficie e uma idade Telychiana, para os sedimentos regressivos posicionados acima da mesma. A distribuição regional é caracterizada por uma expansão da área de deposição, estando o depocentro principal posicionado na parte sul da bacia.

- A seqüência Eo-devoniana envolve os sedimentos da Formação Furnas e a parte inferior da Formação Ponta Grossa. O limite superior da mesma está baseada na caracterização de uma superfície de discordância entre os sedimentos dos membros inferior e médio da Formação Ponta Grossa. Este limite está bem definido em subsuperfície e nos afloramentos, na parte norte da bacia, em termos estratigráficos e bioestratigráficos. A perda de seção contida nesta superfície pode ser da ordem de $7 \mathrm{Ma}$, em função da ausência, na bacia, de sedimentos com idades Neo-Praguiana e Eo-Emsiana (Grahn, 1999). O limite inferior é caracterizado pela discordância da base da Formação Furnas. A distribuição regional da seqüência é bastante regular, traduzida por uma uniformidade no empithamento estratigráfico e por uma relativa similaridade faciológica. Os resultados bioestratigráficos alcançados na datação dos folhelhos basais da Formação Ponta Grossa demonstram que o incremento relativo do nível do mar, representado pela superfície transgressiva, possui uma idade progressivamente mais jovem para leste.

- A Seqüência Eo-Devoniana foi subdividida em duas seqüências de terceira ordem. A primeira sequeência, com sua base colocada no Eo-Ludlowiano, seria marcada pelo estaqueamento de pacotes arenosos, que progressivamente 
atınam e diminuem de espessura em direção à supertıcie de inundação máxima, posicionada no domínio central da unidade e associada a um evento Siluriano. A segunda seqüência, com seu limite inferior associado ao Pridoliano, estaria posicionada no terço superior da Formação Furnas, sendo sua base marcada por uma sucessão de corpos arenosos espessos, definindo uma incisão de pequena magnitude geräda provavelmente por uma queda relativa do nivel do mar.

- A seqüência Meso / Neo-Devoniana é composta, em sua base, pelos sedimentos do membro médio da Formação Ponta Grossa. Os mesmos são constituídos por arenitos finos a médios, por vezes grossos, vermelhos, com estratificação cruzada por onda, depositados sobre a forma de estratos tabulares e organizados em ciclos de engrossamento para o topo. Em sua quase totalidade, esse pacote arenoso está contido no trato de sistema transgressivo, com exceção de alguns corpos arenosos com aspectos sedimentológicos específicos que foram associados ao trato de sistema de mar baixo. O contínuo aumento no nivel do mar gerou na bacia a implantação de condições deposicionais cada vez mais distais. No limite Efeliano / Givetiano, esta dinâmica produz uma mudança brusca no padrão sedimentar, demonstrado pelo afogamento dos depósitos arenosos do membro médio da Formação Ponta Grossa e a deposição de uma seção composta por folhelhos e siltitos intensamente bioturbados, litoestratigraficamente associada ao membro superior desta unidade. Esta nova inundação marinha de grande magnitude repete o processo observado para o Eo-Devoniano, gerando um amalgamento dos depósitos transgressivos.

- A análise do teor de carbono orgânico total, realizada visando configurar as superfícies de máxima inundação das quatro seqüências propostas, indicou os maiores valores para a superfície eo-frasniana. Este dado possibilita definir que em um arcabouço estratigráfico de menor hierarquia, envolvendo toda sedimentação devoniana, a superfície de inundação máxima estaria posicionada em folhelhos do frasniano inferior, quando ocorreria, então, a máxima expansão da bacia. 
- As diversas seções geológicas realizadas indicam que o registro sedimentar preservado, relativo às unidades pré-Furnas, é, aparentemente, descontínuo. A possibilidade de uma descontinuidade no registro sedimentar pôde ser introduzida em função da caracterização de sedimentos associados às unidades Vila"Maria, Ponta Grossa e Aquidauana, ao longo da faixa de afloramento oeste e noroeste da bacia, a partir de rochas até então mapeadas de forma homogênea, ora como pertencentes à Formação Furnas, ora associadas a sedimentos do Ordoviciano-Siluriano.

- Sedimentos associados à Formação Alto Garças, em superfície, na concepção aqui estabelecida, só foram registrados com segurança na região da Chapada dos Guimarães e a noroeste do Lineamento Transbrasiliano.

- A distribuição regional da Formação Vila Maria e a sua relação estratigráfica com a Formação Furnas indicam a presença de um possível controle estrutural na preservação do registro final desta unidade. $\mathrm{Na}$ conceituação apresentada para a Formação Vila Maria, a mesma é composta por um conjunto basal arenoso, com intercalações de diamictitos, sobreposto por siltitos e folhelhos, que gradam para um conjunto arenoso regressivo no topo. A relação de contato é marcada por uma expressiva variação de espessura do conjunto regressivo, provavelmente ligado à erosão pré-Furnas.

- A perda de seção observada na Formação Vila Maria, em diferentes situações, está relacionada a grandes feições estruturais. Ao norte de alinhamentos de direção NW-SE presentes na região de Rio Verde de Mato Grosso (MS), não foram registrados sedimentos que seguramente possam ser associados à Formação Vila Maria. Esta situação se estende ao longo da parte central do flanco oeste da bacia até a falha de São Lourenço, próximo a Rondonópolis (MT). Ao norte desta falha observa-se novamente o registro da unidade. 
- As informações obtidas nos afloramentos, associadas aos dados de subsuperfície, indicam que a ausência desses sedimentos está relacionada a uma perda por erosão, ligada a um evento de mobilização de grande magnitude no tempo pré-Furnas.

- Foi possível diagnosticar a existência de uma relação genética bem definida entre os sedimentos da Formação Furnas e aqueles da Formação Ponta Grossa. Esta relação é explicitada em vários afloramentos, sobretudo naqueles que ocorrem no extremo nordeste da bacia. Para esta região as seções levantadas demonstram a existência de um progressivo afogamento por parte dos sedimentos marinhos da Formação Ponta Grossa que avançam progressivamente sobre a Formação Furnas até recobrirem o embasamento em direção à Bacia do Parecis, demonstrando desta forma que, possivelmente, esta região da Bacia do Parecis figurava como uma borda de bacia para o tempo Furnas.

- A identificação de sedimentos associados ao Membro Médio da Formação Ponta Grossa, normalmente descritos no sudoeste de Goiás, na borda oeste e, também, na área da Bacia do Parecis, possibilitou o mapeamento dos mesmos por toda a extensão norte da bacia.

- As relações estratigráficas observadas para a Formação Aquidauana em novas localidades na borda oeste, bem como no extremo nordeste da bacia, possibilitam aventar a hipótese de um possível controle estrutural por parte do Lineamento Transbrasiliano na deposição desta unidade, definindo um importante evento de mobilidade na Bacia do Paraná de idade préNeo-Carbonífera.

- Foi proposto um novo arranjo estratigráfico para a seção précarbonifera da porção paraguaia da Bacia do Paraná, destacando-se a tentativa de individualizar do pacote ordovício-siluriano os sedimentos que foram 
originalmente descritos como Formação Tobatí, aventando a possibilidade dos mesmos serem de idade mais jovem. Um segundo aspecto importante foi a redefinição da Formação Santa Elena e a sua correlação com os sedimentos da Formação Furnas no Brasil.

- A análise bioestratigráfica das amostras paraguaias permitiu a definição de uma divisão geral para os sedimentos do Eo-Paleozóico. Pela primeira vez, foram registrados sedimentos de idade Eo-Devoniana no Paraguai. A mesma situação ocorre para os sedimentos de idade Neo-Ordoviciana. Estes sedimentos são, normalmente, descritos para a região, mas só agora existem realmente elementos que provam esta idade.

- Os resultados bioestratigráficos preliminares para as amostras brasileiras mostram que existe uma assembléia similar de cryptosporos para o EoSiluriano da Bacia do Paraná. Novas investigações sobre os sedimentos silurianos são necessárias para melhor esclarecer as relações estratigráficas entre os diferentes registros da Formação Vila Maria no Brasil e os sedimentos de mesma idade no Paraguai. Os resultados também sugerem que a idade dos sedimentos associados à parte inferior da Formação Ponta Grossa, na parte oeste da Bacia do Paraná, são provavelmente de idade Lochkoviana, ficando mais jovem para leste onde a mesma é Praguiana.

- Os estudos geocronológicos permitiram a obtenção de um resultado inédito para a idade da Formação lapó. As amostras analisadas geraram uma isócrona, com excelente alinhamento, fornecendo um resultado preliminar para a idade de deposição dos sedimentos de 456,4 +/-6,4 Ma. O material analisado é composto por diamictitos de coloração cinza, de caráter polimítico, com clastos variando entre 0,5 e $2,0 \mathrm{~cm}$. O mesmo foi coletado na Rodovia Castro-Tibagi, na localidade tipo desta unidade, e também em afloramentos da Cachoeira do Rio São Jorge, na cidade de Ponta Grossa (PR). 


\section{Capítulo 6 - Referências Bibliográficas}

ALMEIDA, F.F.M. 1954. Geologia do centro-leste matogrossense. Rio de Janeiro, Divisão de Geologia e Mineralogia, 97 p. (Boletim 150)

ALMEIDA, F.F.M.; MANTOVANI, M. 1975. Geologia e Geocronologia do Granito São Vicente, Mato Grosso. Anais da Academia Brasileira de Ciências, 47 (3/4): $451-458$

ALVARENGA, J.S.; GUIMARÃES, E. M.; ASSINE, L. M.; PERINOTTO, J.A.J.; LARANJEIRA, N.P.F. 1998. Seqüência Ordovício-Siluriana e Devoniana no Flanco Norte da Bacia do Paraná. Anais da Academia Brasileira de Ciências, 70 (3): $587-606$

ANDRADE, S.M. 1988. Distribuição regional dos membros inferior, médio e superior da Formação Ponta Grossa e a semelhança litológica do membro médio com a Formação Aquidauana no flanco nordeste da Bacia do Paraná. In: SBG, Congresso Brasileiro de Geologia, 35, Belém, Anais, 2: 869-879

ANDRADE, S.M. \& CAMARÇO, P.E.N. 1980. Estratigrafia dos sedimentos devonianos do flanco nordeste da Bacia do Paraná. In: SBG, Congresso Brasileiro de Geologia, 31, Balneário de Camboriú, Anais, 5: 2828-2836

ARAÚJO, H.J.T.; NETO, A.S.; TRINDADE, C.A.H; PINTO, J.C.A.; MONTALVÃO, R.M.G.; DOURADO, T.D.C.; PALMEIRA, R.C.B.; TASSINARI, C.C.G. 1981. Geologia. In: Projeto RADAMBRASIL, Folha SF. 21 - Campo Grande, Rio de Janeiro, MME-BRASIL. (Levantamento de Recursos Naturais, 28)

ASSINE, M.L. 1996. Aspectos da estratigrafia das seqüencias pré-carboniferas da Bacia do Paraná no Brasil. São Paulo, Instituto de Geociências, Universidade de São Paulo, Tese de Doutoramento, 207p

ASSINE, M.L.; SOARES, P. C.; MILANI, E. J. 1994. Seqüências tectonosedimentares mesopaleozóicas da Bacia do Paraná, Sul do Brasil. Rev. Bras. Geoc., 24(2): 77-89.

ASSINE, M.L.; PERINOTO, J.A.J; ALVARENGA, 1998a. Formação lapó: glaciação continental no limite ordoviciano/siluriano da bacia do Paraná. Revista Brasileira de Geociências, 2 (1): $51-60$

ASSINE, M.L.; PERINOTO, J.A.J; ALVARENGA, C.J.S.; PETRI, S. $1998 \mathrm{~b}$. Arquitetura estratigráfica, trato deposicionais e paleogeografia da bacia do Paraná no neo-ordoviciano / eo-siluriano. da seqüência Ordovicio-Siluriana na porção Norte da Bacia do Paraná. Revista Brasileira de Geociências, 28(1): $61-78$ 
ASSINE, M.L.; PERINOTO, J.A.J; FULFARO, V.J.; PETRI, S. 1998c. Progradação deltaica no devoniano médio da Bacia do Paraná. Revista Brasileira de Geociências, 28 (2): 125-134

BALDIS, B.A.; MARTINEZ, R.D.; PEREYRA, M.E.; VILLEGAS, C.R. 1991. An approach to the megastrutural Transgondwanic control during Early Paleozoic from the Paleotethys to Andes. Geologica Balcanica, 21 (1): 5-12

BAPTISTA, M.B.; CARTNER-DYER, R. 1966. Ocorrência singular de sedimentos médio-paleozóicos no centro-oeste de Goiás. Rio de Janeiro, DNPM Divisão de Geologia e Mineralogia, 11 p. (Notas Preliminares e Estudos 135)

BARROS, A.; SILVA, R.H. de; CARDOSO, O.R.F.A.; FREIRE, F.A.; JÚNIOR, J.J.S.; RIVETTI, M.; LUZ, D.S. da; PALMEIRA, R.C. de B.; TASSINARI, C.C.G. 1982. Geologia. In: Projeto RADAMBRASIL, Folha SD. 21 - Cuiabá, Rio de Janeiro, MME-BRASIL. (Levantamento de Recursos Naturais, 26)

BERGAMASCHI, S. 1999. Análise estratigráfica do Siluro-Devonianio (Formações Furnas e Ponta Grossa) da Sub-Bacia de Apucarana, Bacia do Paraná, Brasil. São Paulo, Instituto de Geociências, Universidade de São Paulo, Tese de Doutoramento, 167p

BOLZON, R.T., ASSINE, M. L.; GUERRA-SOMMER, M. 1994. Ocorrência de Cooksonia Lang, 1937 na Formação Furnas, Estado do Paraná. In: ALPP, $8^{\circ}$ Reunião de Paleobotânicos e Palinólogos, Resumo das Comunicações, 11

BONHOMME, M. G. 1976. Mineralogie des fraction fines et datations RubidiumStrontium dans le Groupe Bambui (MG-Brésil). Revista Brasileira de Geociências, 6( 4):211-222

BONHOMME, M. G. 1987. Type of sampling and comparison between K-Ar and $\mathrm{Rb}-\mathrm{Sr}$ isotpic dating of fine fractions from sediments in attempt to date young diagenetic events. Chemical Geology, 65: 209-222

BONHOMME, M. G.; CORDANI, U. G.; KAWASHITA, K.; MACEDO, M. H.F. \& THOMAZ FILHO, A. 1982. Radiochronological age and correlation of proterozoic sediments in Brazil. Precambrian Research, 18: 103-118

BORGHI, L; MOREIRA, M.I.C. 1998. Contribuição ao conhecimento do paleozóico Inferior da Bacia do Paraná: Mapeamento geológico da região oriental da Chapada dos Guimarães, estado de Mato Grosso. A terra em revista, 4: 2231

BORGHI, L., ORUÉ, D., FIGUEREDO, L.B., ALVARENGA, D., CLÉRICE, A.M.C. 1997. Correlation between the Itacurubi Group (Paraguay) and the Vila Maria Formation (Brazil), Silurian of the Paraná Basin. In: $3^{\circ}$ Simpósio sobre a Cronoestratigrafia da Bacia do Paraná. Abstract Volume, 7 
BORGHI, L.; MOREIRA, M.I.C.; ROMÃO, F.; YOUNG, Ch.G.K. 1999. O registro do intervalo Ordoviciano - Siluriano da Bacia do Paraná em afloramentos nos estados de Mato Grosso e mato Grosso do Sul, Brasil, e sua correlação no Paraguai. In Jornadas Científicas sobre a Geologia de Paraguay. Resumos, 4 p.

BOUCOT, A.J. 1999. Phanerozoic Gondwanan marine invertebrate presence: palaeoecology, biogeography and climatic inferences. Journal of African Earth Sciences, 27(1): 31-33

BRITO NEVES, B.B.; KAWASHITA, K.; VIEIRA DE MELO E.Z. 1977. Estudo geocronológico do Grupo Estância pelo método Rb/Sr. In: 7th Simpósio de Geologia do Nordeste, Atas, 311-321

BRITO NEVES, B.B; FUCK, R.A.; CORDANI, U.C., THOMAZ-FILHO, A. 1984. Influence of basement structures on the evolution of the major sedimentary basins of Brazil: A case of tectonic heritage. Journal of Geodynamics, 1: 495510

BURGESS, N.D. AND RICHARDSON, J.B., 1991. Silurian cryptospores and miospores from the type Wenlock area, Shropshire, England. Palaeontology, 34(3): $601-628$

BURGESS, N.D.; RICHARDSON, J.B., 1995. Late Wenlock to early Pridoli cryptospores and miospores from south and southwest Wales, Great Britain. Palaeontographica, 236(B): 1-44

CAPUTO, M.V.; CROWELL, J.C. 1985. Migration of glacial centers across Gondwana during Paleozoic Era. Geologycal Society of America Bulletin, 96: 1020-1036

CARVALHO, M.G.P.; MELO, J.H.G.; QUADROS, L.P. 1987. Trilobitas Devonianos do flanco noroeste da Bacia do Paraná. In: SBP, X Congresso Brasileiro de Paleontologia, 10, Rio de Janeiro, Anais, 2: 545-565

CLAUER, N. 1976. Géochimie isotopique du strontium des milieux sédimentaires. Application à la géochronologie de la couverture du craton ouest-africain. Strasbourg, Mémoire Science Géologique. 45, 256p.

CLAUER, N. 1979. A new approach to Rb-Sr dating of sedimentary rochs. In E. Jäger; J.C. Hunziker (ed.) Lectures in Isotope Geology. New York, Springer, $30-51$

CLAUER, N.; KRÖNER, A. 1979. Strontion and argon isotopic homogenization of pelitic sediments during low-grade regional metamorphism: The Pan-African upper Damara sequence of northen Namibia (South West Africa). Earth and Planetary Science, 43: 117-131 
CLOETINGH, S. 1988. Intraplate stresses: a tectonic cause for third-order cycles in apparent sea level? In C.K. WILGUS; B.S. Hastings; H. Posamentier; J. Van Wagoner; C.A. Ross; C.G.St.C. Kendall (ed.) Sea Level Change - an integrated approach. Oklahoma, SEPM Special Publication $n^{\circ} 42,19-30$

COIMBRA, A.M.; RICCOMINI, C.; BOGGIANI, P.C.; GEISICKI, A.L.D. 1995. Ambientes de Sedimentação da Formação Ponta Grossa no estado de Mato Grosso do Sul. Anais da Academia Brasileira de Ciências, 67(4): 518-519 (Resumo de Comunicações)

COLLINSON, J.D. 1986. Alluvial Sedimnets. In H.G. Reading (ed.) Sedimentary Environments and Facies. Oxford, Blackwell, 20-62

CORDANI, U. C.; KAWASHITA, K.; THOMAZ FILHO, A. 1978. Applicabilility of the Rubidium-strontium method to shales and related rocks: Contributions to the Geologic Time Scale. In Studies in Geology, 6, Tulsa, American Associate Petroleum Geologist, 93-118

CORDANI, U. C.; THOMAZ-FILHO, A.; BRITO NEVES, B. B.; KAWASHITA, K. 1985. On the applicability of the $\mathrm{Rb}-\mathrm{Sr}$ method to argillaceous sedimentary rocks: some examples from Precambrian sequences of Brazil. Giornale di Geologia, ser.3, 47(1-2); 253-280

CORREAA, J. A.; CORREIA FILHO, F.C.L.; SCISLEWSKI, G.; NETO, C.; CAVALLON, L.A.; CERQUEIRA, N.L.S.; NOGUEIRA, V.L. 1979. Geologia das regiões centro e oeste de Mato Grosso do Sul - Projeto Bodoquena. Brasilia, DNPM, 111 p. (Série Geologia Básica nº. 3)

CRÓSTA, A. P.; GASPAR, J.C.; CANDIA, M.A.F. 1981. Feições de metamorfismo de impacto no Domo de Araguainha. Revista Brasileira de Geociências, 11 (3): $139-146$

CUNHA, F.M.B. 1986. Evolução Paleozóica da Bacia do Paraná e seu arcabouço tectônico. Rio de Janeiro, Instituto de Geociências, Universidade Federal do Rio de Janeiro, Dissertação de Mestrado, 160p.

DAEMON, R.F., QUADROS, L.P.; SILVA, L.C. da. 1967. Devonian palynology and biostratigraphy of the Paraná Basin. In J.J. Bigarella (ed.), Problems in Brazilian Devonian Geology, Curitiba, Boletim Paranaense de Geociências, 21/22, 99-132

DEL'ARCO, J.O.; SILVA R.G. da; TARAPANOFF, F.; FREIRE, L.G.; MOTA PEREIRA, L.G. da; SOUZA, S.L. de; LUZ, D.S. da; PALMEIRA, R.C.B.; TASSINARI, C.C.G. 1982. Geologia. In: Projeto RADAMBRASIL, Folha SE. 21 - Corumbá e parte da Folha SE. 20, Rio de Janeiro, MME-BRASIL, (Levantamento de Recursos Naturais, 27) 
DIETZ, R.S.; FRENCH, B.; OLIVEIRA, M.A.M. 1973. Araguainha Dome (Goiás) and Serra da Cangalha (Mato Grosso): Probable Astroblemes? In: SBG, Congresso Brasileiro de Geologia, 27, Aracaju, Anais, 1:102. (Resumo de Comunicações)

DINO, R.; RODRIGUES, M.A.C. 1991. Palinomorfos Eodevonianos da Formação Furnas - Bacia do Paraná. In: ALPP, $7^{\circ}$ Reunião de Paleobotânicos e Palinologos, Resumos de Comunicações, 14

DINO, R.; RODRIGUES, M.A.C. 1995. Palinomorfos Eodevonianos da Formação Furnas - Bacia do Paraná. Anais da Academia Brasileira de Ciências, 67: $107-116$

DRAGO, V.A.; PINTO, A.C.; MONTALVÃO, R.M.G.; SANTOS, R.M.G.; SIMŐES, M.A.; OLIVEIRA, F.C.; BEZERRA, P.E.L.; PRADO, P.; FERNANDES, C.A.C.; TASSINARI, C.C.G. 1981. Geologia. In: Projeto RADAMBRASIL, Folha SD. 22 - Goiás, Rio de Janeiro, MME-BRASIL, (Levantamento de Recursos naturais, 25)

DUNOYER DE SEGONZAC, G. 1970. The transformation of clay minerals during diagenesis and low-grade metamorphism: a review. Sedimentology, 15: 281346

ECKEL. E.B. 1959. Geology and mineral resources of Paraguay. United State Geologic Survey, Profissional Paper, 327, p. 1-110.

EYLES, N.; EYLES, C.H. 1993. Glacial geologic confirmation of an intraplates boundary in the Paraná basin of Brasil. Geology, 21: 459-462

EYLES, N.; EYLES, C.H.; FRANÇA, A.B. 1993. Glaciation and tectonics in an active intracratonic basin: the Late Palaeozoic Itararé Group, Paraná basin, Brazil. Sedimentology, 40: 1-25

EYLES, N.; BONORINO, G.G.; FRANÇA, A.B; EYLES, C.H.; PAULSEN, O.L.. 1995. Hydrocarbon-bearing Late Paleozoic glaciated basins of southern and central South America. In A.J. TANKARD; R. SUÁREZ SORUCO; H.J. WELSINK (ed.) Petroleum basins of South America. Tulsa: American Association Petroleum Geologists, Memoir 62, 169-183

FARIA, A.1982. Formação Vila Maria, nova unidade litoestratigráfica siluriana da Bacia do Paraná. Ciências da Terra, 3: 12-15.

FARIA, M.M.; PEREIRA, E. 1994. Análise faciológica preliminar da Formação lapó, Bacia do Paraná. . In: SBG, Congresso Brasileiro de Geologia, 38, Camboriú, Anais, 1: 84-85 
FARIA, M.M.; PEREIRA, E.; DE CESERO, P. 1994. Possíveis evidências de uma mobilidade tectônica pré-Furnas na região do arco de Ponta Grossa, Bacia do Paraná. In: SBG, Congresso Brasileiro de Geologia, 38, Camboriú, Anais, 1: $100-101$

FERNANDES, A. C. S.; PEREIRA, E.; BERGAMASCHI, S., (1994), A presença de Arthrophycus na Formação Vila Maria, no Município de Rondonópolis (MT). Anais da.. Academia Brasileira de Ciências, 67: 383-384 (Resumo de Comunicações)

FERREIRA, F.J.F. 1982. Alinhamentos estruturais magnéticos da região centrooriental da Bacia do Paraná e seu significado tectônico. Geologia da Bacia do Paraná. São Paulo, IPT-Paulipetro, 143-166

FERREIRA, F.J.F.; MORAES, R.A.V.; FERRARI, M.P.; VIANNA, R.B. 1981. Contribuição ao estudo do alinhamento estrutural de Guapiara. In: SBGNúcleo São Paulo, Simpósio Regional de Gelogia, 3, Curitiba, Anais, 1: 226240

FRANÇA, A.B.; MILANI, E.J.; SCHNEIDER, R.L.; LÓPEZ, P.O.; LÓPEZ, M.J.; SUÁREZ S.R.; SANTA ANA, H.; WIENS, F.; FERREIRRO, O.; ROSSELLO, E.A.; BIANUCCI, H.A.; FLORES, R.F.A.; VISTALLI, N.C.; FERNANDEZSEVESO, F.; FUENZALIDA, R.P.; MUÑOZ, N. 1995. Phanerozoic correlation in Southern South America. In A.J. TANKARD; R. SUÁREZ SORUCO; H.J. WELSINK (ed.) Petroleum basins of South America. Tulsa: American Association Petroleum Geologists, Memoir 62, 129-161

FREY, M. 1987. Very low-grade metamorphism of clastic sedimentary rochs. In M. Frey (ed.) Low Temperature Metamorphism. Glasgow, Blackie \& Son Ltda, 958

FREY, M.; KISCH, H. 1987. Scope of Subject. In M. Frey (ed.) Low Temperature Metamorphism. Glasgow, Blackie \& Son Ltda, 1-8

FULFARO. V.J. 1996. Geology of Eastern Paraguay. In P. Comin-Chiaramonti; C.B. Gomes (ed.) Alkaline Magmatism in Central Eastern Paraguay. São Paulo. Edusp, 17-29.

FÚLFARO, V.J.; LANDIM, P.M.B. 1976. Stratigraphy sequences of the intracratonic Paraná Basin. Newsletter Stratigraphy, 4(3): 150-168

FÚLFARO, V.J.; PERINOTTO, J.A.J. 1994. A tectônica Fanerozóica no Mato Grosso do Sul: o "gráben" de Corguinho e a Formação Ponta Porã. In: SBG / Núcleo Brasília, $4^{\circ}$ Simpósio de Geologia do Centro-Oeste, Resumos Expandidos, $61-63$ 
FÚlFARO, V.J.; SAAD, A.R.; SANTOS, M.V.; VIANNA, R.B. 1982. Compartimentação e evolução tectônica da Bacia do Paraná. Revista Brasileira de Geociências, 12(4): 233-256

GALLOWAY, W.E. 1989. Genetic stratigraphic sequences in basin analysis I: architecture and genesis of flooding-surface bounded depositional units. American Association of Petroleum Geologists Bulletin, 73(2): 125-142

GAMA JR., E.; BANDEIRA JR., A.N.; FRANÇA, A.B. 1982. Distribuição espacial e temporal das unidades lioestratigráficas paleozóicas na parte central da Bacia do Paraná. Revista Brasileira de Geociências, 12(4): 578-589

GERRIENNE, P.; BERGAMASCHI, S.; PEREIRA, E.; RODRIGUES, M. A. C.; STEEMANS, P. 1998. Une Association Vegetale du Devonien Inferieur du Bassin du Parana (Brésil): Resultats Preliminaires. In: Neuvième Colloque de I' Organisation Française de Paléobotanique, Liège, Boletim de Resumos, 10-11

GERRIENNE, P.; BERGAMASCHI, S.; PEREIRA, E.; RODRIGUES, M. A. C.; STEEMANS, P. 1999. Cold hardiness in early land plants. submetido

GESICKI, A.L.D. 1996. Geologia da Formação Aquidauana (Neopaleozóico da Bacia do Paraná) na porção centro-norte do estado de Mato Grosso do Sul. São Paulo, Instituto de Geociências, Universidade de São Paulo, Dissertação de Mestrado, 126p

GHIGNONE, J.I. 1980. Relatório da missão de integração das Folhas SD-21 e SD-22. Salvador, Projeto RADAMBRASIL, $4 \mathrm{p}$. (Relatório Interno RADAMBRASIL, 314-G)

GÓES, A.M.O.; SOUZA, J.M.P.; TEIXEIRA, L.B. 1989. Estágio exploratório e perspectivas petrolíferas da Bacia do Parnaíba. In: Petrobrás Departamento de Exploração, Seminário de Interpretação Exploratória, I, Rio de Janeiro, Anais, 25-33

GONÇALVES, A.; SCHNEIDER, R.L. 1970. Geologia do Centro Leste de Mato Grosso. Ponta Grossa, DESUL/Petrobrás. (Relatório interno no 394 )

GONZÁLEZ, M.E.; MUFF, R. 1995. Formación Santa Elena (Silúrico - Devónico), Cuenca del Paraná, Paraguay Oriental. In: SBG / Núcleo Rio Grande do Sul, $6^{\circ}$ Simpósio Sul-Brasileiro do Geologia, Resumos Expandido, 219-221

GONZÁLEZ, M.E.; WIENS, F.; MUFF, R. 1994. Estratigrafia del Paleozoico inferior en el bloque cordillera. Paraguay oriental. In: V Reunión Argentina de Sedimentologia, Actas, 247-252 
GOODWIN, P.W.; ANDERSUN, E.J. 1985. Puntuated aggradational cycles: a general hypothesis of episodic stratigraphic accumulation. The Journal of Geology, 93(5): 515-533

GRAHN, Y. 1992. Revision of Silurian and Devonian Strata of Brazil. Palynology, 16: $35-61$

GRAHN, Y. 1998. Devonian chitinozoan biostratigraphy in the north and northwest part of the Paraná basin, Brasil. Rio de Janeiro, UERJ/FAPERJ, 27p. (Internal Report)

GRAHN, Y. 1999. Recent Progress in Silurian and Devonian Chitinozoan Biostratigraphy of the Paraná Basin in Brazil and Paraguay. In M. A. C. Rodrigues; E. Pereira (ed.) Ordovician - Devonian Palynostratigraphy In Western Gondwana: Update, problems and Perspectives. Rio de Janeiro, UERJ, 147-163

GRAHN, Y.; CAPUTO, M.V. 1992. Early Silurian glaciations in Brazil. Palaeogeography, Palaeoclimatology, Palaeoecology, 99: 9-15

GRAHN, Y., PEREIRA, E.; BERGAMASCHI, S. in press. Silurian and Lower Devonian chitinozoan biostratigraphy of the Paraná Basin in Brazil and Paraguay. Palynology, in press

GRAY, J.; COLBATH, G. K.; FARIA, A.; BOUCOT, A. J. T.; ROHR, D. M. 1985. Silurian-age fossils from the Paleozoic Paraná Basin, Southern Brazil. Geology, 13: 521-525.

GRAY, J.; BOUCOT, A. J. T.; GRAHN, Y.; HIMES, G. 1992. A new record of early Silurian land plant spores from the Paraná Basin, Paraguay (Malvinokaffric Realm). Geological Magazine, 12(6): 741-752

HARLAND, W.B.; ARMSTRONG, R.L.; COX, A.V.; CRAIG, L.E.; SMITH, A.G.; SMITH, D.G. 1990. A Geological Time Scale 1989. London, Cambridge University Press, 131p.

HARRINGTON, H. J. 1950. Geologia del Paraguay Oriental. Universidade de Buenos Aires, Facultad de Ciencias Exactas, Fisicas y Naturales. Contribuciones Cientificas. Série E, Geologia, 1: 1-88

HARRINGTON, H. J. 1956. Paraguay . In W. F. Jenks (ed.) Handbook of South American geology. Geological Society of America, Memoir 65, 99-114

HARRINGTON, H. J. 1972. Silurian of Paraguay. In W. B. N. Berry; A. J. Boucot (ed.) Correlation of the South American Silurian Rochs. Geological Society of America, Special Paper 133, 41-50 
HEILBRON, M.; MOHRIAK, W.U.; VALERIANO, C.M.; MILANI, E.J.; ALMEIDA,J.; TUPINAMBÁ, M. 2000. From collision to extension: the roots of the southeastern continental margin of Brazil. Atlantic Rifts and Continetal Margins. American Geophysical Union, Geophysical Monograph 15: 1-23

HUNZIKER, J. C. 1987. Radiogenic isotopes in very low-grade metamorphism. In: M. Frey (ed.) Low Temperature Metamorphism. Glasgow, Blackie \& Son Ltda, 201-206

HUNZIKER, J. C.; FREY, M.; CLAUER, N.; DALLMEYER, R. D.; FRIEDRISCHEN, H.; HOCHSTRASSER, K; ROGGWILLER, P. \& SCHWANDER, H. 1986. The evolution of illite to muscovite: Mineralogical and isotope data from the Glarus Alps, Switzesland. Contributions to Mineralogy and Petrology, 92:157-180

JONHNSON, M.E. 1996. Stable cratonic sequences and a standard for Silurian eustasy. In B.J. WITZKE; G.A. LUDVIGSON; J. DAY (ed.) Paleozoic sequence stratigraphy: views from the North American craton: Bolder, Colorado, Geologycal Society of America Special Paper n 306, 203-211

KAWASHITA, K. 1972. O método Rb-Sr em rochas sedimentares - aplicação para as bacias do Paraná e Amazonas. São Paulo. Instituto de Geociências, Universidade de São Paulo, São Paulo, Tese de Doutoramento, 111p.

$\mathrm{KISCH}, \mathrm{H} . \mathrm{J}$. 1983. Mineralogy and petrology of burial diagenesis (burial metamorphism ) and incipient metamorphism in clastic rocks. In G. Larsen; C.V. Chillingar (ed.) Diagenesis in Sediments and Sedimentary Rocks, Developments in Sedimentology 25B, Amsterdam, Elsevier, 289-495

KLEIN, G.D. 1995. Intracratonic basins. In C.J. BUSBY; R.V. INGERSOLL (ed.) Tectonics of sedimentary basins. Cambridge, Blackwell Science, p. 459-478

KLEIN, G.D; HSUI, A.T. 1987. Origin of cratonic basins. Geology, 15: 1094-1098

KOLLA, V.; POSAMENTIER, H.W.; EICHENSEER, H. 1995. Stranded parasequences and the forced regressive wedge systems tract: deposition during base-level fall - discussion. Sedimentary Geology, 95: 139-145

KUBLER, B. 1964. Les argiles, indicateurs du métamorphisme. Revue Inst. Fr. Pétrole, 19:1093-1112

KUBLER, B. 1968. Evaluation quantitative du métamophisme par la cristallinité de l'illite. Bull. Centre Rech. Pau-SNPA, 2(2): 385-397

LANA, C.; HIPPERTT, J.; COTA, A. 1999. Aerodynamic sculpturing and Segregation by mass eject bombs from the Araguainha astrobleme, central Brazil. In: SBG / Núcleo Bahia-Sergipe, VII Simpósio Nacional de Estudos Tectônicos. Resumos Expandidos, 63-67 
LANGE, F.W. 1955. Nota preliminar sobre a fáunula do arenito El Carmem, Bolívia. Boletim da Sociedade Brasileira de Geologia, 4(1): 3-25

LANGE, F.W. 1967. Biostratigraphic subdivision and correlation of the Devonian in the Paraná Basin. In: Bigarella, J.J. (ed.) Problems in brasilian Devonian Geology. Boletim Paranaense de Geociências, 21/22: 63-98, plates, 1-7

LARANJEIRA, .. N.P.F., MELO, J.H.G.; PEREIRA, E. 1997. New Palynological Dating of the Vila Maria Formation (Silurian, Paraná Basin) in Southwestern Goiás State, West-Central Brazil. In: $3^{\circ}$ Simpósio sobre a Cronoestratigrafia da Bacia do Paraná. Abstract Volume, 4-5

LEIGHTON, M.W. 1990. Introduction to interior cratonic basins. In M.W. LEIGHTON; D.R. KOLATA; D.F.OLTZ; J.J. EIDEL (ed.) Interior Cratonic basins. Tulsa: American Association Petroleum Geologists, Memoir 51, 1-24

LEIGHTON, M.W.; KOLATA, D.R. 1990. Selected interior cratonic basins and their place in the scheme of global tectonics - a synthesis. In M.W. LEIGHTON; D.R. KOLATA; D.F.OLTZ; J.J. EIDEL (ed.) Interior Cratonic basins. Tulsa: American Association Petroleum Geologists, Memoir 51, 729-797

LIMA, C.; LIMA NETO, F. 1998. Topographic and Structural Expressions of the South American Plate ongoing compression. . In: AAPG, American Association Petroleum Geologists Congress, Rio de Janeiro, Abstracts, 786787

LIRO, L.M. 1997. Sequence stratigraphy: a practitioner's point of view. HGSonline: Sequence Stratigraphy (Liro). (http://members.aol.com/LMLiro/HGS6.html 13/07/99)

LOBOZIAK, S.; MELO, J.H.G.; STEEMANS, P.; BARRILARI, I.M.R. 1995. Miospore evidence por pre-Emsian and Latest Famennian sedimentation in the Devonian of the Paraná Basin, south Brazil. Anais da Academia Brasileira de Ciências, 67(3): 391-392

LOPES-COELHO, A. em preparação. Evolução Tectono-Sedimentar PósDevoniana do "Horst" da Serra Azul, no flanco nordeste da Bacia do Paraná, Vale dos Sonhos (MT). Rio de Janeiro, Faculdade de Geologia, Universidade do Estado do Rio de Janeiro, Dissertação de Mestrado, em preparação

LOPES-COELHO, A.; PEREIRA, E. 2000. Carboniferous transtensional reactivation of the transbrazilian lineament in Paraná basin, Southeastern Mato Grosso State. In International Geological Congress, 31, in press

MACEDO, M. H. F.; BASEI, M. A. S.; BONHOMME, M. G.; KAWASHITA, K. 1984. Dados geocronológicos referentes às rochas metassedimentares do Grupo Itajai (Santa Catarina). Revista Brasileira de Geociências., 14(1): 30-34 
McGREGOR, D.C. 1973. Lower and Middle Devonian spores of eastern Gaspe, Canada. I. Systematics. Palaeontographica B, 142: 1-77

McGREGOR, D.C. 1977. Lower and Middle Devonian spores of eastern Gaspe, Canada. II. Biostratigraphy. Palaeontographica B, 163: 111-142

McGREGOR. D.C. 1984. Late Silurian and Devonian spores from Bolivia. Cordoba, Acad. Nac. de Ciências, 57p. (Miscelanea 69)

McGREGOR, D.C.; CAMFIELD, M. 1976. Upper Silurian ? to Middle Devonian spores of the Moose River Basin, Ontario. Geological Survey of Canada, 263: $1-63$

MELO, J.H.G. 1985. A província malvinocráfrica no Devoniano do Brasil - estado atual dos conhecimentos. Rio de Janeiro, Instituto de Geociências, Universidade Federal do Rio de Janeiro, Dissertação de Mestrado, 890p.

MELO, J.H.G. 1988. The Malvinokaffric realm in Devonian of Brasil. In N.J. MCMILLIAN; A.F. EMBRY; D.J. GLASS (ed.) Devonian of the world. Calgary, Canadian Society of Petroleum Geologists Memoir 14, v. 1: 669-704

MIALL, A.D. 1978. Lithofacies types and vertical profile models in braided river deposits: a summary. In A.D. Miall (ed.) Fluvial Sedimentology, Calgary, Canadian Society of Petroleum Geologists Memoir 5, 597-604

MIALL, A.D. 1985. Architectural-Element Analysis: A new Method of Facies analysis Applied to Fluvial Deposits. Earth Science Review, 22: 261-308

MIALL, A.D. 1990, Principles of Sedimentary Basin Analysis. 2 ed. New York, Spring-Verlag, $668 \mathrm{p}$.

MILANI, E. 1997. Evolução Tectono-Estratigráfica da Bacia do Paraná e seu Relacionamento com a Geodinâmica Fanerozóica do Gondwana SulOcidental. Porto Alegre, Instituto de Geociências, Universidade Federal do Rio Grande do Sul, Tese de Doutoramento, 2v, 255p.

MILANI, E.J.; DAEMON, R.F. 1992. Revisão bio e litoestratigráfica da seção siluro-devoniana dos poços Asunción-1 e Asunción-2 (PECTEN, Paraguai). Curitiba, Petrobras. 19 p. (relatório técnico inédito; NEXPAR)

MILANI, E.J.; RAMOS, V.A. 1998. Orogenias paleozóicas no domínio sulocidental do Gondwana e os ciclos de subsidência da Bacia do Paraná. Revista Brasileira de Geociências., 28(4): 473-484

MILANI, E.J.; ASSINE, M.L.; SOARES, P.C.; DAEMON, R.F. 1995. A seqüência ordovício-siluriana da Bacia do Paraná. Boletim de Geociênciąs da Petrobrás, 9 (2/4): 301-320 
MILLER, M.A.; EAMES, L.E. 1982. Palynomorphs trom the Silurian Medina Group (Lower Llandovery) of the Niagara Gorge, Lewiston, New York, USA. Palynology, 6: 221-254

MITCHUM, R.M. 1977. Seismic stratigraphy and global changes of sea level, part 11: Glossary of terms used in seismic stratigraphy. In C. E. PAYTON (ed.), Seismic Stratigraphy - Applications to Hydrocarbon Exploration. AAPG, Memoir 26, 205-212

MIZUSAKI, A. M. P. 1992. Comportamento do Rb e Sr em sedimentos recentes: Implicações na datação radiométrica de rochas sedimentares. São Paulo, Instituto de Geociências, Universidade de São Paulo, Tese de Doutoramento, $140 \mathrm{p}$.

MIZUSAKI, A. M. P; PEREIRA, E.; MELO, J.H.G.; MILANI, E. em preparação. Aplicação da datação radiométrica pelo método isocrônico $\mathrm{Rb} / \mathrm{Sr}$ nas formações lapó, Vila Maria, Furnas e Ponta Grosa, Bacia do Paraná.

MOREIRA, M.I.C.; BORGHI, L. 1999a. Fácies sedimentares e sistemas deposicionais das formações Alto Garças e Vila Maria na região de Chapada dos Guimarães (MT), borda noroeste da Bacia do Paraná. Revista Brasileira de Geociências, 29 (3): 539-548

MOREIRA, M.I.C.; BORGHI, L. 1999b. Revisão estratigráfica do intervalo Ordoviciano-Siluriano da Bacia do Paraná. Anais da Academia Brasileira de Ciências, 71(4-I): 743-766

MUSSA, D.; BORGHI, L.; BERGAMASCHI, S.; SCHUBERT, G.; PEREIRA, E.; RODRIGUES, M.A.C. 1991. Análise preliminar da tafoflora eodevoniana registrada na Formação Furnas no município de Jaguariaíva, Paraná, Brasil. In: ALPP, $7^{\circ}$ Reunião de Paleobotânicos e Palinólogos, Resumos de Comunicações, 33

MUSSA, D.; BORGHI, L.; BERGAMASCHI, S.; SCHUBERT, G.; PEREIRA, E.; RODRIGUES, M.A.C. 1996. Análise preliminar da tafoflora eodevoniana da Bacia do Paraná na região de Jaguariaiva, PR. Anais da Academia Brasileira de Ciências, 68(1): 65-89

MUTTI, E. 1992. Turbidite Sanstones, S. Donato Milanese, AGIP S.p.A., 275p.

NORTHFLEET, A.A; MEDEIROS, R.A.; MUHLMANN, H. 1969. Reavaliação dos dados geológicos da Bacia do Paraná. Bololetim Técnico da Petrobrás, 12: 291-346 
NUMMEDAL, D.; \& SWIFT, D.J.P. 1987. Transgressive stratigraphy at sequencebounding uncorfomities: Some principes derived from Holocene and Cretaceous examples. In D. Nummedal; O.H. Pilkey; J. D. Howard (ed), Sea-Level flutuations and Coastal Evolution. Special Publications 41.Tulsa, SEPM, 241-260

OLIVEIRA, A.I.; MOURA, P. 1944. Geologia da região de Corumbá e minérios de manganês e ferro do Urucum, Mato Grosso. Boletim da Divisão de Fomento da Produção Mineral, 62: 13-29

OLIVEIRA, M.A.M. 1977. O astroblema de Araguainha. Rio de Janeiro, Petrobrás. 30 p. (relatório técnico inédito; CENPES/DINTEP/MEMÓRIA CENTRAL TÉCNICA nº 670 1213)

OLIVEIRA, M.A.M.; MUHLMANN, H. 1965. Geologia de semidetalhe da região de Mutum, Jaciara, São Vicente e Chapada dos Guimarães. Ponta Grossa, Petrobrás. 63 p., anexo 1-25 (relatório técnico inédito; DEBSP $n^{\circ}$ 300/DEPEX-SEDOC $n^{\circ}$ 119-2261)

OLIVEIRA, S.F. 1991. Acritarcas e Prasinófitas da Formação Ponta Grossa (Devoniano) no flanco noroeste da Bacia do Paraná. São Paulo, Instituto de Geociências, Universidade de São Paulo, São Paulo, Dissertação de Mestrado, 157p.

OLIVEIRA, S.F. 1997. Palinologia da Seqüência Devoniana da Bacia do Paraná no Brasil, Paraguai e Uruguai: Implicações Biocronoestratigráficas, Paleoambientais e Paleogeográficas. São Paulo, Instituto de Geociências, Universidade de São Paulo, Tese de Doutoramento, 188p.

OLIVEIRA, S.F.; ANTONIOLI, L.; DINO,R. 1995. Análise palinológica de sedimentos da Formação Ponta Grossa aflorantes no flanco NW da Bacia do Paraná, MT, Brasil. In: $2^{\circ}$ Simpósio sobre a Cronoestratigrafia da Bacia do Paraná. Resumos Expandidos, 32-35

ORUÉ. D. 1996. Sintese da geologia do Paraguai oriental, com ênfase para o magmatismo alcalino associado. São Paulo, Instituto de Geociências, Universidade de São Paulo, Dissertação de Mestrado, 163p.

ORUÉ. D; ROMERO, A.D.; FIGUEREDO, L.D.; VELÁZQUEZ, J.C.; BÁEZ, A.B.; WEINS, H. 1992. Distribución, fácies y estructuras del Paleozóico Inferior en el paraguay oriental. Archivo Cemit-DDI. Universidad Nacionale de Asunción. Resumo.

PARENTI COUTO, J. G., CORDANI, U. G., KAWASHITA, K., IYER, S. S.; MORAES, N. M. P. 1982. Considerações sobre a idade do Grupo Bambuí, com base em análises isotópicas de $\mathrm{Sr}$ e $\mathrm{Pb}$. Revista Brasileira de Geociências, 11, 5-16 
PEREIRA, E. 1992. Análise estratigráfica do Paleozóico Médio da Sub-Bacia do Alto Garças, no Sudoeste de Goiás, Bacia do Paraná, Brasil. Rio de Janeiro, Instituto de Geociências, Universidade Federal do Rio de Janeiro, Dissertação de Mestrado, 172p.

PEREIRA, E. 1994. Análise estratigráfica do Paleozóico Médio da Sub-Bacia do Alto-Garças. (Bacia do Paraná), no Sudoeste de Goiás. In: SBG / Núcleo Brasília, $4^{\circ}$ Simpósio de Geologia do Centro-Oeste, Resumos Expandidos, $59-60$

PEREIRA. E. 1998. Estratigrafia da Formação Vila Maria (Llandoveriano), na Subbacia de Alto Garças (Bacia do Paraná), Brasil. Anais da Academia Brasileira de Ciências, 70(3): 501-525

PEREIRA, E., BERGAMASCHI, S. 1996. Estudo da evolução tecto-sedimentar das seqüencias ordoviciana, siluriana e devoniana nas Sub-Bacias de Apucarana e de Alto Garças, Bacia do Paraná, Gondwana Ocidental. In: Simpósio Sul-Americano do Siluro-Devoniano, Anais, 219-238

PEREIRA, E.; BERGAMASCHI, S. ; LARANJEIRA, N. P. F. 1995a. Novos aspectos estratigráficos do Paleozóico Médio da Bacia do Paraná no Estado de Mato Grosso. Anais da Academia Brasileira de Ciências, 67(3): 385-386 (Resumo de Comunicações)

PEREIRA, E.; BERGAMASCHI, S.; RODRIGUES, M. A. 1998. Sedimentary evolution of the Ordovician, Silrurian and Devonian sequences of Paraná basin in Brazil. Zentralblatt für Geologie und Paläontologie, Teil I, 3/6: 779792

PEREIRA, E.; BERGAMASCHI, S. LARANJEIRA, N. P. F.; FERNANDES, A. C. S. 1995b. Nova Ocorrência de Sedimentos Eossilurianos (Formação Vila Maria), no Bordo Noroeste da Bacia do Paraná, Região de Rondonópolis (MT). In: $2^{\circ}$ Simpósio sobre a Cronoestratigrafia da Bacia do Paraná, Resumos Expandidos, 32-35

PEREIRA, E.; RODRIGUES, M.A.; BERGAMASCHI, S.; OLIVEIRA, S.F. 1996. Reconhecimento e caracterização de um rifte pós-Devoniano no flanco setentrional da Bacia do Paraná, no domínio da Serra Azul, nas regiões de Barra do Garças e Nova Xavantina, MT. In: SBG, Congresso Brasileiro de Geologia, 39, Salvador, Anais, 5: 313-317

PETRI, S. 1948. Contribuição ao estudo do Devoniano paranaense. Rio de Janeiro, Departamento Nacional da Produção Mineral, 125p. (Boletim da Divisão de Geologia e Mineralogia, 129) 
POSAMENTIER, H.W. \& ALLEN, G.P, no prelo, Siliciclastic Sequence Stratigraphy - Concepts and Applications, AAPG, no prelo.

POSAMENTIER, H.W.; ALLEN, G.P. 1993. Variability of the sequence stratigraphic model: effects of local basin factors. Sedimentary Geology, 86: 91-109

POSAMENTIER, H.W.; JAMES, D.P. 1993. An overview of sequence-stratigraphic concepts; use and abuses. In H.W. POSAMENTIER; C.P. SUMMERHAYES; B.U. HAQ; G.P. ALLEN (ed.) Sequence stratigraphy and facies associations. Oxford, Blackwell, IAS- Special Publication n $n^{\circ}$ 18, 3-18

POSAMENTIER, H.W., JERVEY, M.T.; VAIL, P.R., 1988, Eustatic controls on clastic depositional I - conceptual framework. In C.K. WILGUS; B.S. Hastings; H. Posamentier; J. Van Wagoner; C.A. Ross; C.G.St.C. Kendall (ed.) Sea Level Change - an integrated approach. Oklahoma, SEPM Special Publication $n^{\circ} 42,109-124$

POSAMENTIER, H.W.; ALLEN, G.P.; JAMES, D.P;TESSON, M. 1992. Forced regression in a stratigraphic framework: concepts, examples, and exploration significance. American Association of Petroleum Geologists Bulletin, 76(11): 1687-1709

PUTZER, H. 1962. Die geologie von Paraguay. Beitr. Reg. Geol. Erde, 2: 1-182.

QUADROS, L. P.; MELO, J.H.G. 1986. Ocorrência de restos vegetais em sedimentos continentais do Paleozóico Médio do estado de Goiás. Anais da Academia Brasileira de Ciências, 58: 611 (Resumo de Comunicações)

QUINTAS, M.C.L. 1995. O embasamento da Bacia do Paraná: reconstrução geofísica de seu arcabouço. São Paulo, Instituto Astronômico e Geofísico, Universidade de São Paulo, Tese de Doutoramento, 213p.

RAMOS, A.N. 1970. Aspectos páleo-estruturais da Bacia do Paraná e sua influência na sedimentação. Boletim Técnico da Petrobrás, 13: 85-93

RAPELA, C.W.; PANKHURST, R.J.; CASQUET, C.; BALDO, E.; SAAVEDRA, J.; GALINDO, C. 1998. Early evolution of the Proto-Andean margin of South America. Geology, 26 (8): 707-710

RIBEIRO FILHO, W.; LUZ, J.S.; ABREU FILHO, W.; PIMENTEL, G.B. da; BERBERT, C.O.; MELLO, J.C.R. da, ROSITO, J.; OLIVATTI, O. 1975. Projeto Serra Azul - relatório final, Goiânia, DNPM/CPRM, 4v. (Relatório do arquivo técnico da DGM, 2407) 
RICHARLsUN, J.B. 1996. Lower and Middle Palaeozoic recurds of terrestrial palynomorphs. In: J. Jansonius; D.C. McGregor (Ed.), Palynology: principles and applications. American Association of Stratigraphic Palynologists Foundation, 555-574

RICHARDSON, J.B.; LISTER, T.R. 1969. Upper Silurian and Lower Devonian spore assemblages from Welsh Bordeland and south Wales. Paleontology, 12(2): 201-252

RICHARDSON, J.B.; MCGREGOR, D.C. 1986. Silurian and Devonian spore zones of the Old Red Sandstone continent and adjacent regions. Geological Survey of Canada, Bulletin, 364: 1-79

ROBINSON, D.; WARR, L.. N.; BEVINS, R. E. 1990. The illite "crystallinity" technique: a critical appraisal of its precision. Journal of Metamorphic Geology, 8:333-344

ROCHA, P.L.F. 1998. Estudo da litosfera do Brasil entre os paralelos de $17 \mathrm{~S} e$ 33S, a partir de dados gravimétricos, magnéticos e de fluxo de calor. Rio de Janeiro, CNPq, Observatório Nacional, Tese de Doutoramento, 159p.

RODRIGUES, M. A. C.; PEREIRA, E.; BERGAMASCHI, S. 1989. Ocorrência de Psilophytales na Formação Furnas, borda leste da Bacia do Paraná. Boletim do Instituto de Geociências da USP (Publicação Especial), 7: 35-43

RODRIGUES, M. A. C.; PEREIRA, E.; BERGAMASCHI, S.; LARANJEIRA, N. P. F. 1995. Aspectos estratigráficos do intervalo Neo-OrdovicianoMesodevoniano do bordo nordeste da Bacia do Paraná (Sub-Bacia do alto Garças). In: $2^{\circ}$ Simpósio sobre a Cronoestratigrafia da Bacia do Paraná, Resumos Expandidos, 3-18

ROSS, C.A.; ROSS, J. R. 1988. Late Paleozoic transgressive-regressive deposition. In C.K. WILGUS; B.S. Hastings; H. Posamentier; J. Van Wagoner; C.A. Ross; C.G.St.C. Kendall (ed.) Sea Level Change - an integrated approach. Oklahoma, SEPM Special Publication $n^{\circ} 42,228-247$

ROSS, C.A.; ROSS, J. R. 1996. Silurian sea-level fluctuations. In B.J. WITZKE; G.A. LUDVIGSON; J. DAY (ed.) Paleozoic sequence stratigraphy: views from the North American craton: Bolder, Colorado, Geologycal Society of America Special Paper $n^{\circ}$ 306, 187-192

SCHENEIDER, R.L.; MÜHLMANN, H.; TOMMASI, E.; MEDEIROS, R.A.; DAEMON, R.F.; NOGUEIRA, A.A. 1974. Revisão estratigráfica da Bacia do Paraná. In: SBG, Congresso Brasileiro de Geologia, 28, Porto Alegre, Anais, 1: 41-65 
SCHMTT, R.S.; IROUW, R.A.J., VAN SCHMUS, W.R. 1999. Reconhecimento de uma orogenia Cambro-Ordoviciana no Bloco Cabo Frio - SE da Faixa Ribeira - evidências estruturais e dados geocronológicos. . In: SBG/UNESP, Simpósio de Geologia do Sudeste, 6, São Pedro, Boletim de Resumos, p. 15

SCHOBBENHAUS FILHO, C. 1975. Carta geológica do Brasil ao milionésimo, folha Goiás. Brasília, DNPM, $114 \mathrm{p}$

SCHUBERT, G.; BORGHI, L. 1991. Sobre a ocorrência inédita de uma tafoflora devoniana na região de Chapada dos Guimarães (Bacia do Paraná, MT). Anais da Academia Brasileira de Ciências, 63: 96-97 (Resumo de Comunicações)

SCOTESE, C.R. 1999. Gondwana's climate changes. Journal of African Earth Sciences, 27(1): 172-173

SILVEIRA FILHO, N.C.; RIBEIRO, C.L. 1971. Informações geológicas preliminares sobre a estrutura vulcânica de Araguainha-Mato Grosso. Brasilia, DNPM, Distrito Centro-Oeste. (Relatório Interno)

SIQUEIRA, L. P. 1989. Bacia dos Parecis. Boletim de Geociências da Petrobrás, $3(1 / 2): 3-16$

SOARES, P.C. 1991. Tectônica sinsedimentar cíclica na Bacia do Paraná controles. Curitiba. Tese de Professor Titular, UFPR, 131p.

SOARES, P.C.; LANDIM, P.M.B.; FÚLFARO, V.J. 1978. Tectonic cycles and sedimentary sequences in the brazilian intracratonic basins. Geological Society of America Bulletin, 89: 181-191

STEEMANS, P. 1989. Palynostratigraphie de l'Eodévonien dans l'ouest de l'Europe, Bruxelles, Service Géologique de Belgique, 453 p. (Mém. Expl. Cartes Géologiques et Minières de la Belgique, 27)

STEEMANS, P. 1999. Ordovician to Lower Devonian cryptospore / trilete spore stratigraphy in Western Gondwana and correlation with type sequence in Western Europe. In M. A. C. Rodrigues; E. Pereira (ed.) Ordovician Devonian Palynostratigraphy In Western Gondwana: Update, problems and Perspectives. Rio de Janeiro, UERJ, 11-25

STEEMANS, P.; LE HÉRISSÉ, A.; BOZDOGAN, N. 1996. Ordovician and Silurian cryptospores and miospores from Southeastern Turkey. Review of Palaeobotany and Palynology, 93: 35-76

STREEL, M.; LOBOZIAK, S. 1996. Paleozoic spores and pollen. In J. Jansonius; D.C. Mcgregor (ed.), Palynology principles and applications, American Association of Stratigraphic Palynologist Foundation, V. 2, 575-587 
STURESSON, U.; DRONOV, A.; SAADRE,T. 1999. Lower Ordovician iron ooids and associeted oolitic clays in Russia and Estonia: a clue to the origin of iron oolites? Sedimentary Geology, 123: 63-80

THEILEN-WILLIGE, B. 1981. The Araguainha impact structure / central Brazil. Revista Brasileira de Geociências, 11: 91-97

THOMAZ FILHO, A. 1976. Potencialidade do método Rb-Sr para a datação de rochas sedimentares argilosas. São Paulo, Instituto de Geociências, Universidade de São Paulo, Tese de Doutoramento, 128p.

THOMAZ FILHO, A.; BONHOMME, M. G. 1979. Datations isotopiques Rb-Sr et KAr dans le Groupe Bambuí, à São Francisco (MG), au Brésil. Phase metamorphique brésilienne synchrone de la première phase panafricaine. $C$. R. Académie Science - Série D, 289: 1221-1224

THOMAZ FILHO, A.; LIMA, V. Q. 1981. Datação radiométrica de rochas sedimentares pelíticas pelo método Rb-Sr. Boletim Técnico da Petrobrás, 24(2): $109-119$

THOMAZ FILHO, A.; CORDANI U.G.; KAWASHITA, K. 1976. Aplicação do método $\mathrm{Rb}-\mathrm{Sr}$ na datação de rochas sedimentares argilosas da Bacia do Paraná. In: SBG, Congresso Brasileiro Geologia, 29, Ouro Preto, Anais, 4: 289-302.

TOSELLI, A. J.; WEBER, K. 1982. Anquimetamorfismo en rocas del Paleozoico inferior en el noroeste de Argentina - Valor de la cristalinidad de la illita como índice. Acta Geologica Liloana, 14:187-200

VAIL, P.R., MITCHUM, R.M.; THOMPSON, S. III. 1977a. Seismic stratigraphy and global changes of sea level, part 3: Changes of the sea level from coastal onlap. In C. E. PAYTON (ed.), Seismic Stratigraphy - Applications to Hydrocarbon Exploration. AAPG, Memoir 26, 63-81

VAIL, P.R., MITCHUM, R.M.; THOMPSON, S. III. 1977b. Seismic stratigraphy and global changes of sea level, part 4: Global cycles of relative changes of the sea level. In C. E. PAYTON (ed.), Seismic Stratigraphy - Applications to Hydrocarbon Exploration. AAPG, Memoir 26, 83-97

VAN WAGONER, J.C.; POSAMENTIER, H.W.; MITCHUM, R.M.; VAIL, P.R. SARG, J.F.; LOUTIT, T.S.; HARDENBOL, J. 1988. An overview of the fundamentals of sequence stratigraphy and key definitions. In C.K. WILGUS; B.S. Hastings; H. Posamentier; J. Van Wagoner; C.A. Ross; C.G.St.C. Kendall (ed.) Sea Level Change - an integrated approach. Oklahoma, SEPM Special Publication $n^{\circ} 42,39-45$ 
VAN WAGONER, J. C.; MITCHUM, R. M.; CHAMPION, K. M.; RAHMANIAN, V.D. 1990. Siliciclastic Sequence Stratigraphy in Well logs, Cores and Outcrops: Concepts for High-Resolution Correlation of Time and Facies. Tulsa, American Association of Petroleum Geologists, 55p. (Methods in Exploration Series, 7)

VIDOTTI, R.M.; EBINGER, C.J.; FAIRHEAD, J.D. 1998. Gravity signature of the western Paraná basin, Brasil. Earth and Planetary Science Letters, 159: 117132

WALKER, R. G. 1990. Facies modeling and sequence stratigraphy. Journal of Sedementary Petrology, 60: 777-786

WALKER, R. G; PLINT, G. 1992. Wave-and-storm-dominated shallow marine systems. In R.G. WALKER; N.P. JAMES (ed.) Facies models: response to sea level change. Ontario, Geological Association of Canada, 219-238

WANG, Y.; LI, J.; WANG, R. 1997. Latest Ordovician cryptospore from southern Xinjiang, China. Review of Paleobotany and Palynology, 99: 61-74

WILGUS, C.K., HASTINGS, C.G., KENDAL, S.T.C., POSAMENTIER, H.W., ROSS, C.A.; VAN WAGONER, J.C. 1988. Sea-leve/ changes: an integrated approach. Oklahoma, SEPM Special Publication $n^{\circ} 42,407 p$.

WOLFART, R. 1961. Stratigraphie und Fauna des älteren Paleozoikums (Silur, Devon) in Paraguay. Geologische Jahrbuch, 78: 29-102.

WOOD, G.D. AND MILLER, M.A. 1997. The stratigraphic and paleoecologic importance of acritarchs, chitinozoans and spores from the Silurian Vargas Peña Shale. In: $2^{\circ}$ European Meeting on the Palaeontology and Stratigraphy of South America, Heidelberg. Poster section

YOUNG, T.P. 1992. Ooidal ironstones from Ordovician Gondwana: a review. Palaeogeography, Palaeoclimatology, Palaeoecology, 99: 321-347

ZALÁN, P.V.; WOLFF, S.; CONCEIÇÃO, J.C.J.; VIEIRA, I.S.; ASTOLFI, M.A.M.; APPI, V.T.; ZANOTTO, O.A. 1987. A divisão tripartite do Siluriano da Bacia do Paraná. Revista Brasileira de Geociências, 17(3): 242-252

ZALÁN, P.V., WOLFF, S., ASTOLFI, M.A.M., VIEIRA, I.S., CONCEIÇÃO, J.C.J., APPI, V.T., NETO, E.V.S., CERQUEIRA, J.R., MARQUES, A. 1990. The Paraná Basin, Brazil. In M.W. LEIGHTON; D.R. KOLATA, D.F. OLTZ; D.F.; J.J. EIDEL (ed.) Interior Cratonic Basins. Tulsa, American Association of Petroleum Geologists Memoir 51, 681-701 


\section{ANEXO I - ESTAMPA I}

1 - Ambitisporites (?) varvdovii

(Furo RD-116 - 388,48 m / Lâm. 51114)

2 - Laevolancis divellomedium

(Furo RD-116 - 400,95 m / Lâm. 51113)

3 - Laevolancis divellomedium

(Furo RD-116 - 388,48 m / Lâm. 51114)

4 - Dyadospora murusdensa

(Furo RD-116 - 400,20 m / Lâm. 51112)

5 - Segestrespora laevigata

(Furo RD-116 - 388,48 m / Lâm. 51114)

6 - Tetrahedraletes medinensis

(Furo RD-116 - 400,95 m / Lâm. 51113)

7 - Tetrahedraletes medinensis

(Furo RD-116 - 400,20 m / Lâm. 51112)

8 - Tetrahedraletes medinensis

(Poço 2-RI-1-PR - 5274 m / Lâm. 51608)

9 - Rimosotetras problematica

(Furo RD-116 - 400,95 m / Lâm. 51113) 
10 - Rimosotetras problematica

(Aflor. E9P47Am1 - Cachoeira das Perdizes, Fm. Vila Maria / Lâm. 51692)

11 - Velatitetras retimembranifera

(Furo RD-116 - 368,61 m / Lâm. 51100)

12 - Velatitetras laevigata

(Furo RD-116 - 400,20 m / Lâm. 51112)

13 - Velatitetras sp.

(Aflor. E9P47Am1 - Cachoeira das Perdizes, Fm. Vila Maria / Lâm. 51692)

Observação: As formas estão aumentados em 640 vezes 


\section{ESTAMPA I}
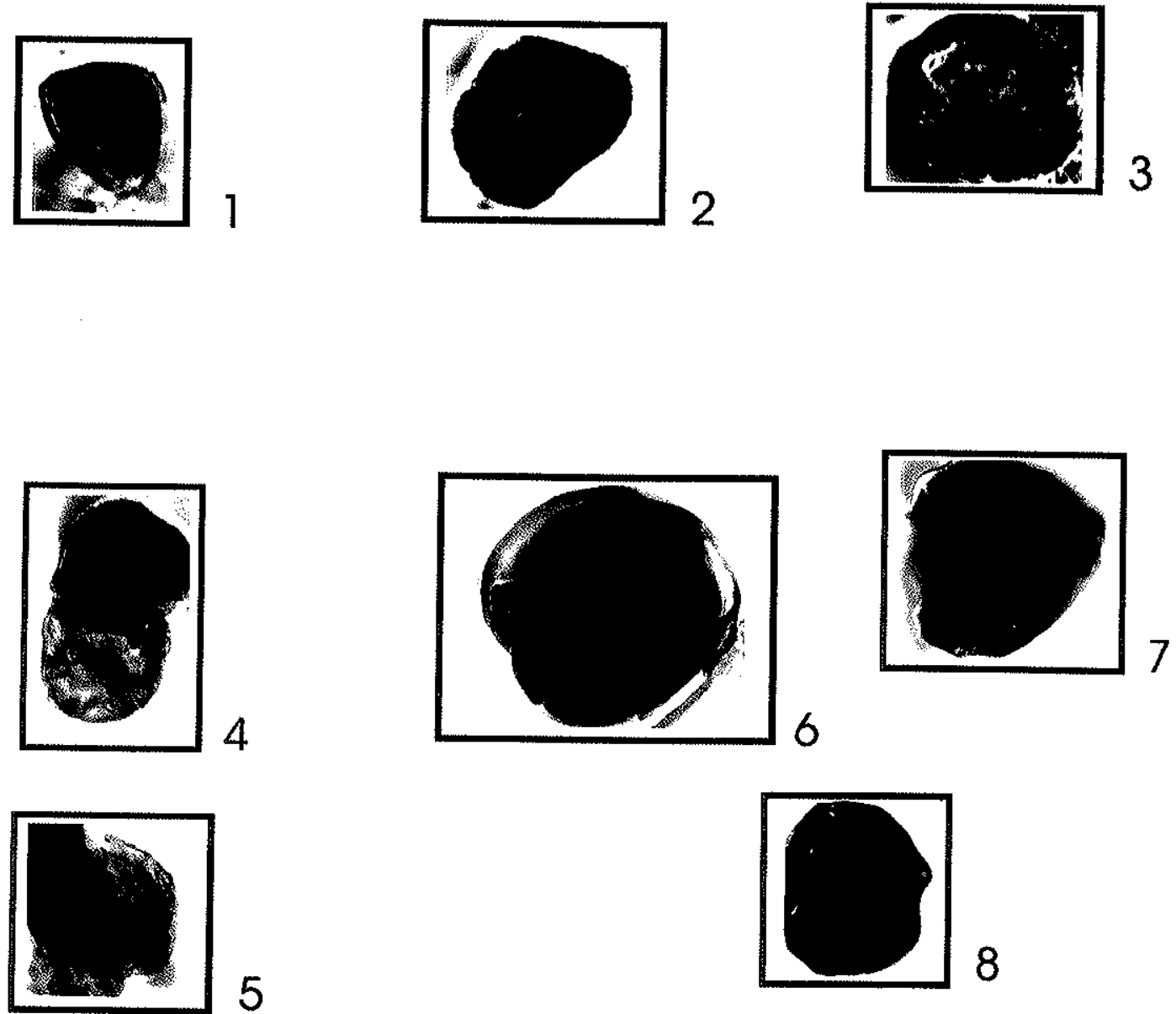

5
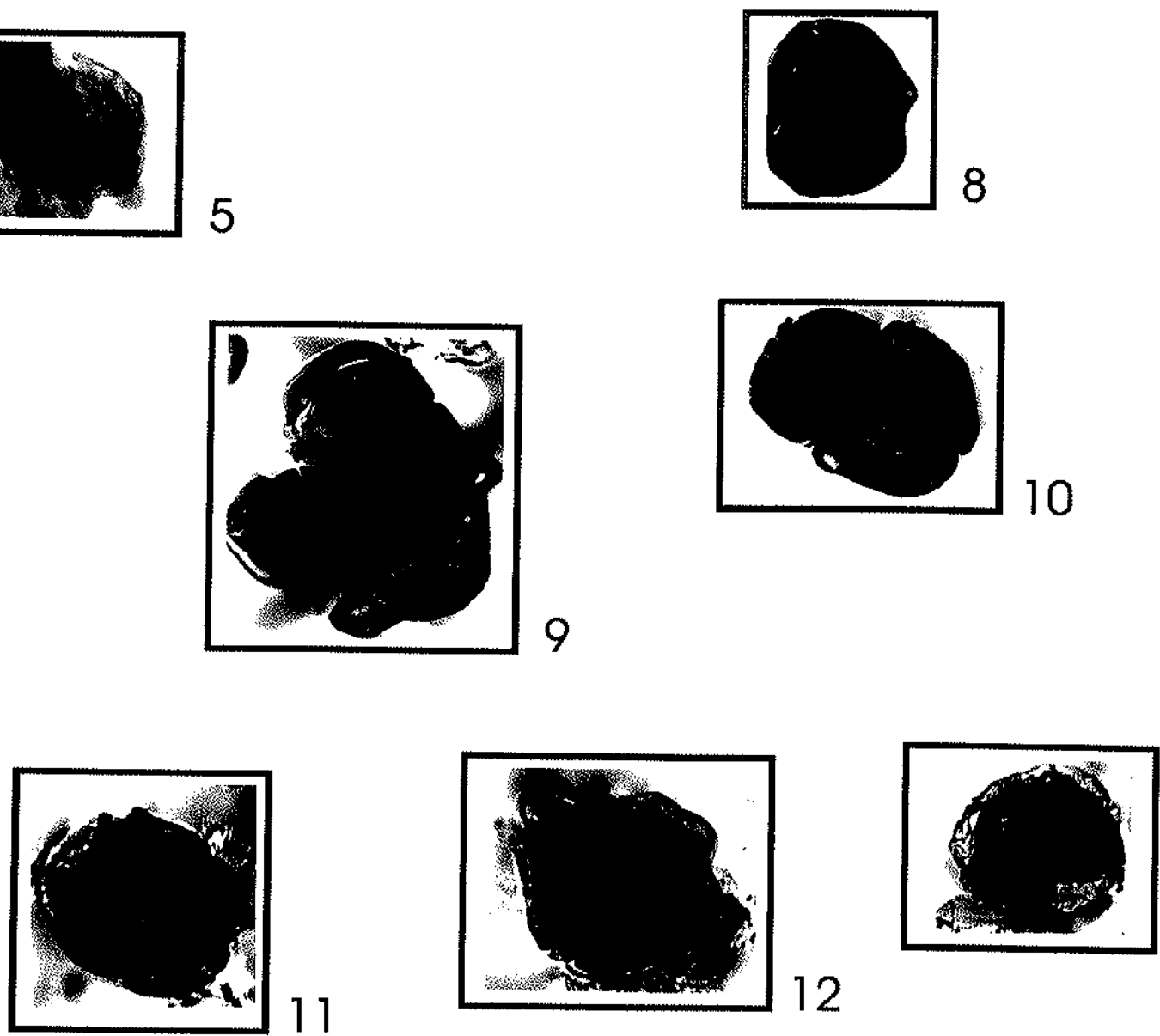

13

11

12 